UNIVERSIDADE DE SÃO PAULO

FACULDADE DE FILOSOFIA LETRAS E CIÊNCIAS HUMANAS

DEPARTAMENTO DE LETRAS MODERNAS

PROGRAMA DE PÓS-GRADUAÇÃO EM LÍNGUA ESPANHOLA E

LITERATURAS ESPANHOLA E HISPANO-AMERICANA (LELEHA-USP)

ADRIANA MARCELLE DE ANDRADE

\begin{abstract}
A cortesia em grupos de estudo:
as diferentes estratégias utilizadas por brasileiros e chilenos no contexto acadêmico
\end{abstract}

(versão corrigida)

São Paulo, 2016 


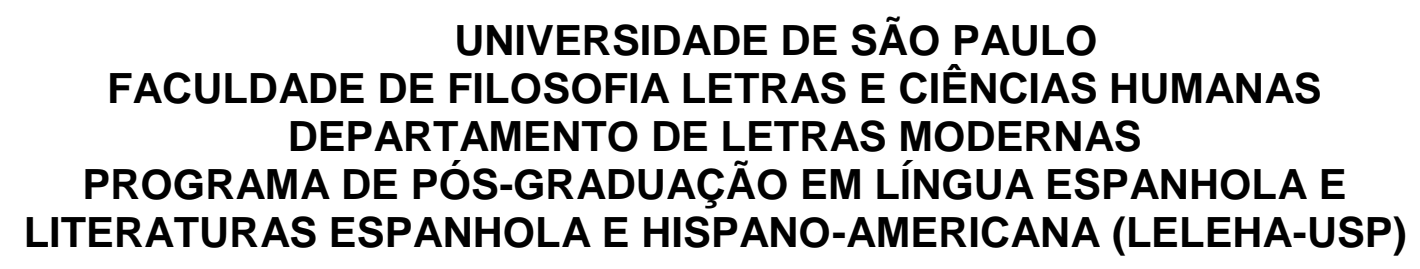

ADRIANA MARCELLE DE ANDRADE

\title{
A cortesia em grupos de estudo: as diferentes estratégias utilizadas por brasileiros e chilenos no contexto acadêmico
}

\begin{abstract}
Adriana Marcelle de Andrade
Tese de Doutorado apresentada ao Programa de Pós-graduação em Língua Espanhola e Literaturas Espanhola e Hipano-americana do Departamento de Letras Modernas da Faculdade de filosofia Letras e Ciências Humanas da Universidade de São Paulo para a obtenção do título de Doutor em Letras.
\end{abstract}

Orientadora: Profa. Dra. María Zulma Moriondo Kulikowski

De acordo

(versão corrigida)

São Paulo, 2016 
Autorizo a reprodução e divulgação total ou parcial deste trabalho, por qualquer meio convencional ou eletrônico, para fins de estudo e pesquisa, desde que citada a fonte.

Catalogação na Publicação

Serviço de Biblioteca e Documentação

Faculdade de Filosofia, Letras e Ciências Humanas da Universidade de São Paulo

Andrade, Adriana Marcelle de
A cortesia em grupos de estudo: as diferentes
estratégias utilizadas por brasileiros e chilenos no
contexto acadêmico / Adriana Marcelle de Andrade ;
orientadora María Zulma Moriondo Kulikowski. - são
Paulo, 2015.
217.
Tese (Doutorado) - Faculdade de Filosofia, Letras
e Ciências Humanas da Universidade de São Paulo.
Departamento de Letras Modernas. Área de
concentração: Língua Espanhola e Literaturas Espanhola
e Hispano-Americana.
1. pragmática sociocultural. 2. cortesia. 3.
imagem social. 4. interação oral. 5. premissas
culturais. I. Kulikowski, María Zulma Moriondo ,
orient. II. Título.


ANDRADE, A. M. de. A cortesia em grupos de estudo: as diferentes estratégias utilizadas por brasileiros e chilenos no contexto acadêmico. Tese apresentada à Faculdade de Filosofia, Letras e Ciências Humanas da Universidade de São Paulo para a obtenção do título de Doutor em Letras.

Aprovado em:

Banca examinadora

Prof. Dr.

Instituição:

Julgamento:

Assinatura:

Prof. Dr.

Julgamento:

Instituição:

Assinatura:

Prof. Dr.

Instituição:

Julgamento:

Assinatura:

Prof. Dr.

Instituição:

Julgamento:

Assinatura:

Prof. Dr.

Instituição:

Julgamento:

Assinatura: 
A Geni Tavares de Aguiar Andrade In memoriam 


\section{AGRADECIMENTOS}

Este trabalho não teria sido possível sem a ajuda valiosa de um grande número de pessoas, a quem quero expressar meus sinceros agradecimentos, sem deixar de salientar que quaisquer falhas e limitações neste estudo são de minha única responsabilidade.

À Profa. Dra. María Zulma Moriondo Kulikowski (FFLCH-USP), pelo apoio incessante e minucioso trabalho de orientação.

Ao Prof. Dr. Luiz Antônio da Silva (FFLCH-USP) e Profa. Dra. Elisabetta Santoro (FFLCH-USP), pelas preciosas recomendações durante o processo de exame de qualificação.

Ao Prof. Dr. Lésmer Antonio Montecino Soto (PUC-Chile), pelo seu assessoramento.

A todos os professores e alunos que cooperaram com a elaboração do material de análise desta pesquisa.

À amiga Profa. Dra. Elisa Cristina Moraes Rodrigues Lopes, pelos anos de apoio e colaboração.

Aos amigos Carla Vargas Valdés e Juan Carlos Páez Rodríguez, pela constante disposição em ajudar-me.

Aos meus queridos pais, irmãs e amigos, pelo valoroso estímulo e compreensão.

A Rafael de Freitas, meu esposo, pelo incansável amparo. 
O Brasil ganhou um novo espelho; não será ele mais fiel que os anteriores? A solda da cordialidade já não disfarça nem embute interesses de classes e de regiões inteiras; a máscara da "índole pacífica do nosso povo" cai inteiramente por terra e dá lugar ao rosto das aspirações verdadeiras e distintas, nítidas como nunca, dos vários segmentos. Ressentimentos de classe assumiram-se como também pessoais e se expuseram nas redes da internet, novos fóruns da polis titubeante que começamos a experimentar e a habitar. O decantado ganho da nossa mestiçagem está pronto para ser posto à prova: nossa esperteza de antropófagos oswaldianos, a contribuição original do "povo brasileiro" de Darcy Ribeiro, o visionarismo da Tropicália, nosso jogo de cintura para o samba, o futebol e a prática do jeitinho surgem como velhas peças otimistas de um quebra-cabeça cada vez mais difícil de armar. (...) A imagem não é bonita, resiste a sublimações, e agora é também capaz de nos encarar com olhos implacáveis - talvez seja essa a maior das novidades.

Alcides Villaça 


\section{LISTA DE ILUSTRAÇÕES}

\section{IMAGENS}

Imagem 1 - Desacordo - (BRASL07/12/2009)...............................................

Imagem 2 - Atitude não-verbal - (BRASL07/12/2009)..................................97

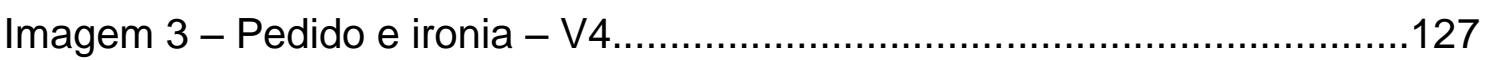

\section{GRÁFICOS}

Gráfico 1 - Parte I - Pergunta 1- São Paulo ………………….....................166

Gráfico 2 - Parte I - Pergunta 1- Santiago do Chile ...................................167

Gráfico 4 - Parte II - Pergunta 3 - a) - Santiago do Chile ............................179

Gráfico 5 - Parte II - Pergunta 3 - b) - São Paulo .........................................181

Gráfico 6 - Parte II - Pergunta 3 - b) - Santiago do Chile............................. 183

\section{QUADROS}

Quadro 1 - Autorrepetição e estratégias de cortesia envolvidas na construção da imagem dos participantes de grupos de estudos acadêmicos em São Paulo (Brasil).

Quadro 2 - Autorrepetição e estratégias de cortesia envolvidas na construção da imagem dos participantes de grupos de estudos acadêmicos em Santiago do Chile.

Quadro 3 - Heterorrepetição e estratégias de cortesia envolvidas na construção da imagem dos participantes de grupos de estudos acadêmicos em São Paulo (Brasil). 120

Quadro 4 - Heterorrepetição e estratégias de cortesia envolvidas na construção da imagem dos participantes de grupos de estudos acadêmicos em Santiago do Chile. 121

Quadro 5 - Ato exortativos e estratégias de cortesia envolvidas na construção da imagem dos participantes de grupos de estudos acadêmicos em São Paulo (Brasil)

Quadro 6 - Ato exortativo e estratégias de cortesia envolvidas na construção da imagem dos participantes de grupos de estudos acadêmicos em Santiago do Chile 


\section{TABELAS}

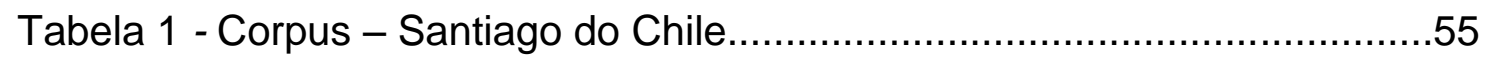

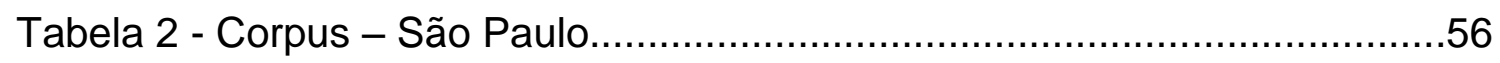

Tabela 3 - São Paulo - Total: 40 testes - Dados sociológicos.......................58

Tabela 4 - Santiago do Chile - Total: 40 testes - Dados sociológicos...........59

Tabela 5 - Aplicação do Teste de Hábitos Sociais - Parte I - Pergunta 1 - São

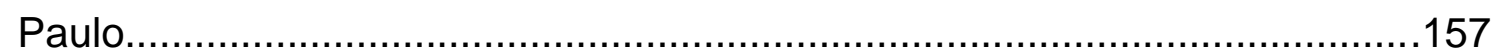

Tabela 6 - Aplicação do Teste de Hábitos Sociais - Parte I - Pergunta 1 -

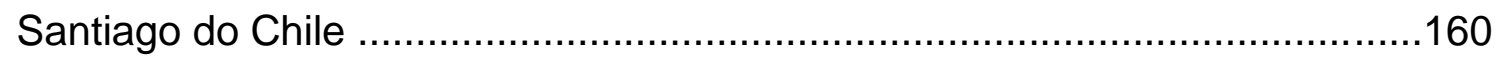

Tabela 7 - Aplicação do Teste de Hábitos Sociais - Parte I - Pergunta 1- São Paulo - Justificativas à resposta afirmativa - Proporções .............................166

Tabela 8 - Aplicação do Teste de Hábitos Sociais - Parte I - Pergunta 1Santiago do Chile - Justificativas à resposta afirmativa - Proporções ...........167

Tabela 9 - Aplicação do Teste de Hábitos Sociais - Parte I - Pergunta 2- São Paulo e Santiago do Chile - Gestão da autoimagem - Proporções ...............171

Tabela 10 - Aplicação do Teste de Hábitos Sociais - Parte 2 - Pergunta 3 - a) São Paulo - Ato assertivo - Proporções ..................................................176

Gráfico 3 - Parte 2 - Pergunta 3 - a) - São Paulo ……….............................177

Tabela 11 - Aplicação do Teste de Hábitos Sociais - Parte 2 - Pergunta 3 - a) Santiago do Chile - Ato assertivo - Proporções ...........................................178

Tabela 12 - Aplicação do Teste de Hábitos Sociais - Parte II - Pergunta 3 - b) São Paulo - Ato exortativo - Proporções …………………………….......182

Tabela 13 - Aplicação do Teste de Hábitos Sociais - Parte II - Pergunta 3 - b) Santiago do Chile - Ato exortativo - Proporções 184 


\section{RESUMO}

ANDRADE, A. M. de. A cortesia em grupos de estudo: as diferentes estratégias utilizadas por brasileiros e chilenos no contexto acadêmico. 2014. $217 \mathrm{f}$. Tese (doutorado) - Faculdade de Filosofia, Letras e Ciências Humanas, Universidade de São Paulo, São Paulo, 2015.

Esta pesquisa se fundamenta na pragmática sociocultural, com o propósito de descrever, dentro do próprio sistema sociocultural a que pertencem os falantes do estudo, a produção e a interpretação das mensagens transmitidas (Bravo, 2010). Pretende-se ir, por um lado, para além da análise da transcrição de um corpus específico (Charaudeau, 2012) e, por outro, abrir novos horizontes para os estudos interdisciplinares, contrastivos e holísticos, cujo objeto seja o uso da linguagem. Assim, como objetivo, esta pesquisa procura descrever e contrastar estratégias pragmáticas, com foco na manifestação da cortesia, em português e em espanhol, em comunidades de fala de São Paulo e Santiago do Chile, indagando quais recursos os interlocutores, universitários em grupos de estudos, utilizam no trabalho de imagem em atos assertivos e exortativos. Para isso, apresentamos uma proposta metodológica que visa a delinear aspectos das construções discursivas, a revelar a complexidade dos fenômenos da interação oral e a variedade de componentes envolvidos em uma situação comunicativa. Nesse sentido, definimos quatro etapas: o enfoque interdisciplinar, a análise do corpus oral, os testes de hábitos sociais (Hernandez Flores, 2002; Contreras, 2004 e Bernal, 2007) e o contraste cross-cultural. O corpus é composto por vinte e cinco horas de gravações em vídeo de reuniões em grupo de estudantes universitários, no Chile e no Brasil, e quarenta testes de hábitos sociais de cada comunidade de fala também. Em uma análise sincrônica, identificamos no contexto brasileiro, a tendência de o indivíduo projetar a imagem de cordialidade, cooperação e semelhança na gestão da autoimagem. Entre os interlocutores chilenos, a imagem de ordem e a de hierarquia foram as que se evidenciaram. Na gestão interrelacional, destacamos contrastes, além de semelhanças, entre algumas estratégias pragmáticas: o fenômeno da atenuação assertiva, nas intervenções brasileiras, em maior número se associa a posturas afiliativas, na gestão da alo- e autoimagem; no material de análise chileno, a atenuação, muitas vezes é construída como uma estratégia autocêntrica; em ambas as comunidades de fala encontramos mecanismos de autorrepetição e intensificação, vinculados à força argumentativa e fenômenos de heterorrepetição que promovem o contato social; no entanto, no contexto chileno, a heterorrepetição ocorre na expressão do desacordo com mais frequência do que no contexto brasileiro; realizados de maneira direta, encontramos atos exortativos, como a petição, em interações brasileiras e chilenas, mas nas primeiras, geralmente, ocorrem atos de justificação, a expressão da diminuição do custo para os ouvintes e, em maior grau, mecanismos de atenuação. Os resultados, que encontraram eco em estudos de outras ciências do comportamento humano, na análise do corpus e nas respostas dos informantes dos testes hábitos sociais, podem sinalizar a projeção de experiências específicas de um corpus a um estilo de cortesia que se estenda a outras situações de comunicação sem prescindir da enorme diversidade do uso da linguagem (Bravo, 2004).

Palavras-chave: pragmática sociocultural, cortesia, imagem social, interação oral, premissas culturais. 


\begin{abstract}
ANDRADE, A. M. de. A cortesia em grupos de estudo: as diferentes estratégias utilizadas por brasileiros e chilenos no contexto acadêmico. 2014. 217 f. Tese (doutorado) - Faculdade de Filosofia, Letras e Ciências Humanas, Universidade de São Paulo, São Paulo, 2015.
\end{abstract}

\title{
Politeness in study groups: different strategies used by Brazilians and Chileans in an academic context
}

This research is based upon sociocultural pragmatics and aims at describing - within the very sociocultural system to which the speakers participating in this study belong - how transmitted messages are produced and interpreted (Bravo, 2010). On the one hand, this research aims at going beyond analyzing the transcription from a certain corpus (Charaudeau, 2012); on the other, opening up new horizons for interdisciplinary, contrastive and holistic studies on the use of language. Thus, this research aims at describing and contrasting pragmatic strategies focused on how politeness is shown - both in Portuguese and Spanish - within speaking communities from São Paulo, Brazil, and Santiago, Chile while investigating which features are used by interlocutors (undergraduates in study groups) in their face-work during assertive and persuasive acts. In order to do so, our proposed methodology is aimed at outlining the core of discursive constructions, unveiling the complexity of verbal interaction phenomena and the variety of components involved in a communication situation. To that end, four stages have been defined: interdisciplinary focus, speech corpus analysis, social behavior tests (Hernandez Flores, 2002; Contreras, 2004 and Bernal, 2007) and cross-cultural contrast. The corpus consists of about five hours of videotaped undergraduate study group meetings in Chile and Brazil and 40 social behavior tests from each speaking community. In a synchronous analysis, we found that Brazilian individuals tend to convey an image of kindness, cooperation and similarity in managing their self-image. An image of order and hierarchy stood out among Chilean interlocutors. As to inter-relationship management, contrasts and similarities were noted between a few pragmatic strategies: in Brazilian interventions, the assertive attenuation is mostly connected with affiliative postures in alloimage and self-image management; in the Chilean material, attenuation is often constructed as an self-centric strategy. Self-repetition and intensification mechanisms (linked to argument strength) and hetero-repetition fostering social contact were found in both speaking communities. Nevertheless, hetero-repetition occurs more often when expressing disagreement in Chilean context than in the Brazilian context; it is performed directly and with exhortative acts (such as petition) in Brazilian and Chilean interactions, but the former usually present justification acts, expression of effort reduction for listeners and - in a higher degree - attenuation mechanisms. The results - which were supported by studies from other behavioral sciences, corpus analysis and answers from informants of social behavior tests - can indicate the projection of experiences that are specific to a corpus to a politeness style comprising other communication situations without forgoing the immense diversity of the use of language (Bravo, 2004).

Keywords: sociocultural pragmatics, politeness, face, verbal interactions, cultural premises. 


\section{RESUMEN}

ANDRADE, A. M. de. A cortesia em grupos de estudo: as diferentes estratégias utilizadas por brasileiros e chilenos no contexto acadêmico. 2014. $217 \mathrm{f}$. Tese (doutorado) - Faculdade de Filosofia, Letras e Ciências Humanas, Universidade de São Paulo, São Paulo, 2015.

\section{La cortesía en grupos de estudios: las diferentes estrategias utilizadas por brasileños y chilenos en el contexto académico.}

Esta investigación se basa en la pragmática sociocultural, con el fin de describir, dentro del propio sistema sociocultural al que pertenecen los hablantes del estudio, la producción y la interpretación de los mensajes transmitidos (Bravo, 2010). Pretendemos ir, por un lado, más allá del análisis de la trascripción de un corpus específico (Charaudeau, 2012) y, por el otro, abrir nuevos horizontes a los estudios interdisciplinarios, contrastivos y holísticos, cuyo objeto sea el uso del lenguaje. Así es que, como objetivo, esta investigación, busca describir y contrastar estrategias pragmáticas, con foco en la manifestación de la cortesía, en portugués y español, en comunidades de habla de São Paulo y Santiago de Chile, preguntándose qué recursos los interlocutores, universitarios en grupos de estudio, han utilizado en la actividad de imagen en actos asertivos y exhortativos. Para tanto, se presenta aquí una propuesta metodológica que pretende delinear el trasfondo de las construcciones discursivas, desvelar la complejidad de los fenómenos de la interacción oral y la variedad de componentes que intervienen en una situación comunicativa. Así es que definimos cuatro etapas: el enfoque interdisciplinario, el análisis del corpus oral, los tests de hábitos sociales (Hernández Flores, 2002; Contreras, 2004 y Bernal, 2007) y el contraste cross-cultural. El corpus se compone de aproximadamente veinticinco horas de videograbaciones de reuniones en grupo de estudiantes universitarios chilenos y brasileños y cuarenta tests de hábitos sociales, de cada comunidad de habla también. En un análisis sincrónico, identificamos en el contexto brasileño, la tendencia del individuo a proyectar la imagen de cordialidad, cooperación y semejanza en la gestión de la autoimagen. Entre los interlocutores chilenos, la imagen de orden y la imagen de jerarquía fueron las que se evidenciaron. En la gestión interrelacional, destacamos contrastes, además de semejanzas, entre algunas estrategias pragmáticas: el fenómeno de la atenuación asertiva, en las intervenciones brasileñas, en mayor número se asocia a posturas de afiliación, en la gestión de la alo- y autoimagen; en el material de análisis chileno, la atenuación frecuentemente se construye como una estrategia autocéntrica; en ambas comunidades de habla encontramos mecanismos de autorrepetición e intensificación, vinculados a la fuerza argumentativa, y fenómenos de alorrepetición que promueven el contacto social. Sin embargo, en el contexto chileno la alorrepetición trabaja en la expresión del desacuerdo más frecuentemente que en el contexto brasileño; realizados de manera directa, encontramos actos exhortativos, como la petición, en interacciones brasileñas y chilenas, pero en las brasileñas, en general, actúan actos de justificación, la expresión de la disminución del coste para los oyentes y, más mecanismos de atenuación que en las chilenas. Los resultados, que encontraron eco en estudios de otras ciencias del comportamiento humano, en el análisis del corpus y en las respuestas de los informantes a los tests de hábitos sociales, pueden facilitar la proyección de experiencias específicas de un corpus a un estilo de cortesía que se extienda a otras situaciones de comunicación sin prescindir de la enorme diversidad del uso del lenguaje (Bravo, 2004).

Palabras clave: pragmática sociocultural, cortesía, imagen social, interacción oral, premisas culturales. 


\section{SUMÁRIO}

INTRODUÇÃo

CAPÍTULO I -

A CORTESIA

1. A cortesia e aspectos pragmáticos: uma perspectiva sociocultural . 23

1.1 Das teorias fundadoras dos estudos da cortesia ao modelo

sociocultural .................................................................................... 27

1.2 A definição das categorias de imagem social e aspectos teóricos ........... 33

1.3 Os atos de fala dentro do modelo sociocultural....................................... 40

2. Cortesia e princípios pragmáticos de atenuação.................................. 43

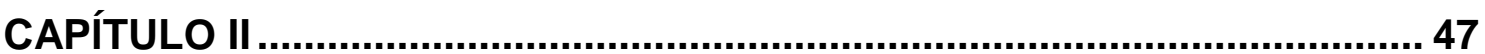

PREMISSAS CULTURAIS E MANIFESTAÇÕES LINGUÍSTICAS: ASPECTOS METODOLÓGICOS PARA A ANÁLISE DA (DES)CORTESIA E DEMAIS PAPÉIS PRAGMÁTICOS ................................................................... 47

1. Aspectos metodológicos de pragmática contrastiva ........................... 49

2. Apresentação e descrição do corpus oral ......................................... 52

3. Apresentação e descrição dos testes de hábitos sociais ....................56

3.1 Descrição dos dados sociológicos .......................................................5 57

CAPÍTULO III -

DESCRIÇÃO A PARTIR DO SISTEMA SOCIOCULTURAL.................. ERROR! BOOKMARK NOT DEFINED.

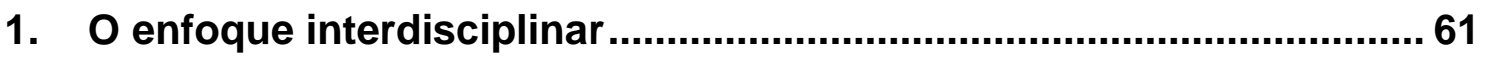

1.1 A cordialidade, a alegria e o jeitinho são brasileiros? ..............................61

1.2 Premissas culturais subjacentes às formações discursivas e ao

comportamento comunicativo do brasileiro .....................................................70

1.3 Os componentes da imagem social brasileira .......................................72

1.4 A ordem e o caos na sociedade chilena............................................... 73

1.5 Premissas culturais subjacentes às formações discursivas e ao comportamento comunicativo do chileno ......................................................77

1.6 Os componentes da imagem social chilena .......................................... 79

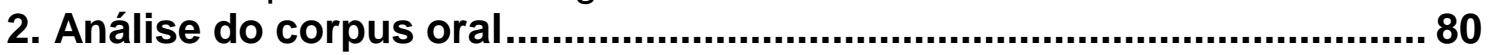

2.1 As estratégias de cortesia envolvidas na construção da imagem dos participantes da interação brasileira e chilena.................................................. 82

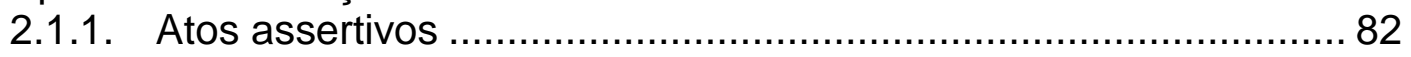

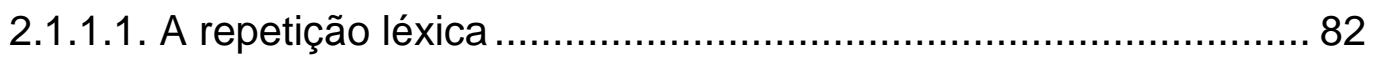

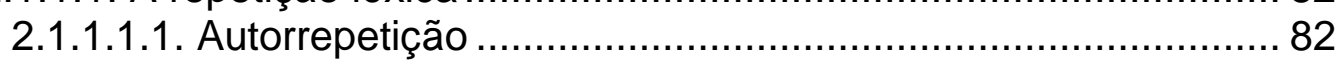

2.1.1.1.2. Apresentação dos resultados: a autorrepetição e as estratégias de cortesia envolvidas na construção da imagem dos participantes da interação brasileira e chilena............................................................... 103

2.1.1.1.3. Heterorrepetição ......................................................... 110

2.1.1.1.4. Apresentação dos resultados: a heterorrepetição e as estratégias de cortesia envolvidas na construção da imagem dos participantes da interação brasileira e chilena.............................................................. 1188

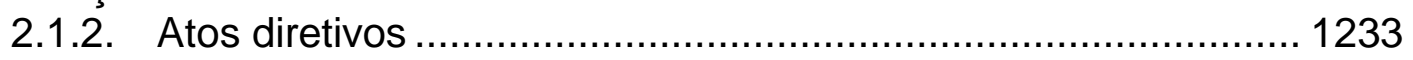


2.1.3. Apresentação dos resultados: atos diretivos e as estratégias de cortesia envolvidas na construção da imagem dos participantes da interação brasileira e chilena.

3. $O$ teste de hábitos sociais

3.1.Descrição do teste de hábitos sociais criado para o presente estudo

49

3.2.Discussão dos resultados do teste de hábitos sociais 1566

3.2.1. Considerações sobre os fenômenos de cortesia e a gestão das imagens a partir dos testes de hábitos sociais

3.3. Dados contrastivos sobre percepções dos informantes a respeito do comportamento cortês e a gestão de imagens

O CAPÍTULO IV -

O CONTRASTE CROSS-CULTURAL: EXPOSIÇÃO E FUNDAMENTAÇÃO

DOS RESULTADOS

1. Exposição e fundamentação dos resultados provenientes das etapas de enfoque interdisciplinar, análise do corpus oral e aplicação de testes de

hábitos sociais

CONCLUSÕES 198

BIBLIOGRAFIA 204

ANEXO 


\section{INTRODUÇÃO}

Nas interações verbais, a necessidade de reduzir ao mínimo o conflito com o interlocutor pode abrir caminho à manifestação das estratégias de cortesia, esta atividade linguística e estratégica que tem como fim alcançar com êxito uma meta prevista. Quando falamos de cortesia linguística, fazemos referência a uma série de operações que regulam as relações humanas, no âmbito da comunicação, e que podem ser concernentes à manutenção do equilíbrio de uma atividade comunicativa (Briz, 2004). Cada cultura, entretanto, cria em seus membros expectativas diferentes do comportamento discursivo e estabelece diversos princípios que orientam as interações comunicativas.

A esse respeito, a incorporação do elemento sociocultural aos estudos da cortesia linguística em diferentes comunidades de fala é o alvo desta pesquisa, que visa a abordar o fenômeno linguístico da cortesia com foco na possibilidade de suas diversas configurações segundo cada contexto.

Para a nossa pesquisa o conceito de imagem é primordial, no que diz respeito ao termo delimitado por Goffman (1970), que sustenta que os indivíduos estão emocionalmente comprometidos com uma imagem de si mesmos, a qual necessita ser aprovada pela sociedade e dá lugar a uma serie de regras para o contato interpessoal. Contudo, a projeção de uma imagem de si mesmo ou do grupo, ao qual se pertence, nem sempre se realiza dentro da dimensão da cortesia (Bravo, 2002a). Como, por exemplo, uma atividade autocêntrica de autoafirmação não realiza a atividade de cortesia, mas sim uma atividade de imagem, que pode ser interpretada de maneiras diferentes segundo as premissas culturais de cada comunidade de fala.

Nesse sentido, um discurso pode apresentar outro propósito: o de "fazer boa figura", "criar uma boa impressão" diante dos demais. E isso sinaliza seu firme compromisso com a imagem social, que é moldada de acordo com as convenções socioculturais.

Se a imagem social é delimitada socioculturalmente, se as atividades de cortesia são concebidas e interpretadas dentro desse sistema de crenças e valores compartilhados, é fundamental, pois, fazer referência ao contexto 
sociocultural no momento de explicar e descrever o funcionamento das estratégias linguísticas interrelacionais.

Assim, este estudo examina a relação entre estratégias pragmáticas, com foco nas de cortesia, e os aspectos culturais em duas comunidades de fala, das cidades de São Paulo e Santiago do Chile, em situações em que as condições de produção linguística permitem que os interlocutores tenham acesso e controlem os recursos da linguagem (Bravo, 2004b).

Desenvolvemos aqui, portanto, um estudo da cortesia, cujo centro de interesse é a análise sincrônica do fenômeno, com base na perspectiva pragmática. Nesse sentido, a hipótese condutora da análise que empreendemos é a existência de diferenças socioculturais relacionadas à manifestação formal e à função interativa das estratégias pragmáticas como as de cortesia.

Especialmente, esta pesquisa se centra na interação produzida nos chamados encontros de estudo, situações em que alunos universitários se reúnem a fim de se prepararem juntos para exames, seminários e produzirem quaisquer trabalhos grupais. A situação comunicativa dos grupos de estudos inseridos no âmbito acadêmico condiciona a produção dos atos de fala como também a interpretação de seu significado. A finalidade desses encontros permite a seus membros a co-construção, transmissão e consolidação de conhecimentos (Granato e Hatvey, 2005). É produzida, portanto, nesse contexto, uma atividade discursiva em que se manifestam estratégias que controlam a situação de fala, a mensagem, o contato na interação e que coloca em relevo a maneira como se fala e quem ouve.

A fim de delinear alguns contrastes socioculturais, subjacentes aos linguísticos, pretendemos destacar como estudantes chilenos e brasileiros, participantes desses grupos, buscam o equilíbrio da atividade comunicativa que desempenham.

Como objetivo geral, assim sendo, centramo-nos em descrever e contrastar as estratégias de cortesia em português e espanhol - nas comunidades de fala de São Paulo e Santiago do Chile -, indagando como esses recursos contribuem para a manutenção do equilíbrio na interação social, em encontros de estudo no âmbito acadêmico. 
Como objetivos específicos, buscamos:

(i) descrever aspectos da idiossincrasia de ambas as comunidades de fala, suas atitudes, pressupostos, premissas e valores socioculturais; como também identificar crenças linguísticas quanto às funções da cortesia no âmbito acadêmico e na dinâmica das relações sociais, as quais estão ancoradas nos contextos sociais de ambas as línguas e no contexto específico de encontros de estudo em cada comunidade de fala em questão;

(ii) inferir os recursos utilizados na manifestação do trabalho de imagem (face work') realizado pelos participantes nas interações específicas nos grupos acadêmicos de estudo, em português e em espanhol; identificar e contrastar a coconstrução de imagens nessas interações, em ambas as línguas e em determinados atos de fala, partindo do contexto específico de encontros de estudo;

(iii) contemplar e contrastar as variações linguísticas e socioculturais entre as comunidades de fala em análise.

À vista disso, buscamos responder nesta pesquisa as seguintes questões:

a) quais aspectos das premissas culturais, nos contextos socioculturais que compartilham os falantes, permitem-lhes que uma interpretação de expressões de cortesia seja (in)adequada à situação?

b) qual a interrelação entre as imagens que concebem os estudantes brasileiros e chilenos e as estratégias de cortesia adotadas pelos informantes do corpus?

c) quais são as principais diferenças observadas na busca do equilíbrio social entre os estudantes chilenos e brasileiros em encontros de estudo?

Para o presente estudo foi realizada a construção de um corpus oral através da filmagem de encontros de estudos no Brasil e no Chile no âmbito

\footnotetext{
${ }^{1}$ Face work é um conceito que, segundo Goffman (1979), corresponde às ações que uma pessoa executa para manter o equilíbrio entre a sua conduta e a sua imagem própria. Este conceito será analisado nas próximas seções e também poderá ser aludido como trabalho de imagem.
} 
acadêmico, cujas transcrições se encontram anexadas a este trabalho em um CD de dados. E, conforme aludiu Contreras Fernández (2004), cremos que é necessária a combinação de mais de um método na compilação de dados para compor o material de análise. Assim, para alcançar resultados satisfatórios, aplicamos e analisamos também testes de hábitos sociais (Hernández-Flores, 2002, 2003; Contreras, 2004; e Bernal, 2007) a fim de investigar mecanismos sociolinguísticos, pragmáticos e linguísticos que os falantes mencionam em determinados contextos situacionais e culturais. Os testes de hábitos sociais têm como finalidade obter dados confiáveis e com rigor científico, para confirmar as impressões do analista, como também precisar as características da imagem social e dos valores culturais implícitos ao comportamento cortês. Nossa proposta metodológica, portanto, aventa uma análise que busca ir além da descrição de um corpus particular, com o intuito de delinear o que está por trás das construções discursivas (Charaudeau, 2012).

Ao considerar a cortesia linguística um fenômeno sociocultural, é necessário tratar das suas manifestações a partir de enfoques interdisciplinares, uma vez que a linguagem faz parte de outras atividades humanas (Bravo, 2004a). Dessa forma, realizando uma intersecção entre a Pragmática, a Análise da Conversação e demais disciplinas sociais, apresentamos e experimentamos aqui uma proposta metodológica fundamentada, portanto, em um enfoque que inclui um estudo de atitudes e comportamentos humanos mediante a investigação conjunta em áreas como a Pragmática, Sociologia, História, entre outras.

Durante a evolução desta pesquisa, por tanto, encontramo-nos diante da necessidade de estabelecer aspectos metodológicos que pudessem aproximarse das condições sociais que regem os recursos da linguagem e às quais os falantes têm acesso. Formulamos, então, entre os aspectos práticos, e com o fim de alcançar os objetivos propostos, quatro etapas metodológicas: o enfoque interdisciplinar, a análise do corpus oral, a aplicação de testes de hábitos sociais e o contraste cross-cultural.

Naturalmente nosso interesse são os fenômenos linguísticos selecionados das conversações do corpus, entretanto se encontrarmos constantes relações entre recorrentes elementos extralinguísticos e recursos linguísticos em três das quatro etapas de nossa metodologia, nos estudos de 
comportamento humano, na análise do corpus e nas respostas dos informantes que responderem aos testes de hábitos sociais, teremos acesso a tendências socioculturais.

Mais especificamente, a respeito dos fatores que motivaram a escolha do tema central desta pesquisa, nosso interesse se enquadra no estudo das manifestações de cortesia inseridas no âmbito acadêmico, em que eventos como os encontros de estudo suscitam atos de fala como: pedir informações, explicações, (auto)correções, enfim, situações propícias para o advento de um intenso trabalho de imagem e gestão interrelacional ${ }^{2}$. Contudo, reiteramos que este estudo, além de analisar realizações comunicativas em seu hoje e seu agora também torna possível a projeção dessas experiências, ao propor uma descrição de um estilo de cortesia estensível a outras situações comunicativas possíveis às comunidades de fala definidas aqui.

Promover uma caracterização da cortesia linguística das variedades do espanhol falado em Santiago do Chile e do português falado em São Paulo, na instância acadêmica, bem como a análise do comportamento discursivo dos estudantes universitários contribuirão para o progresso dos estudos da cortesia e dos estudos contrastivos entre espanhol e português.

Quanto à esfera do processo de ensino-aprendizagem de espanhol como língua estrangeira e de português para falantes de outras línguas, este estudo leva em consideração que os conhecimentos e as capacidades que influem na comunicação e a maneira como a língua veicula conteúdos culturais são extremamente importantes no desenvolvimento da competência comunicativa de um aprendiz. Desse modo, buscamos oferecer recursos pertinentes ao desenvolvimento da competência pragmática e sociolinguística de falantes de outras línguas, aprendizes de espanhol ou português brasileiro, dado que a formação de um estudante de língua estrangeira precisa contemplar amostras de recursos linguísticos envolvidos em estratégias de cortesia, para que possam construir e interpretar discursos de forma adequada ao contexto de enunciação e ao tipo de interação social.

O contraste entre línguas e culturas no estudo da cortesia oferece ferramentas para o discernimento das diferenças interculturais, uma vez que 0

\footnotetext{
${ }^{2} \mathrm{O}$ conceito de gestão interrelacional foi proposto por Spencer-Oatey (2000) como conceito hiperonímico
} de cortesia. 
conhecimento das expressões de cortesia e de suas condições de uso poderá prever mal-entendidos nas interações sociais interculturais, fazê-los mais evitáveis ou menos nocivos.

A seguir, apresentamos como se organiza cada uma das principais etapas de desenvolvimento deste trabalho de pesquisa.

O Capítulo I - A Cortesia trata do marco teórico que a define como um recurso pragmático da interação e um fenômeno social e linguístico. Esta seção apresenta o estado da questão, destacando a progressão e a relevância dos modelos de análise da área aplicados à presente pesquisa, a partir de uma visão metodológica. Justificamos as fontes nas quais se fundamenta este estudo entre distintos modelos e abordagens e arrolamos os conceitos e aspectos teóricos que fundamentam a análise que realizamos. Delimitamos, portanto, conceitos, buscamos definições e apresentamos os critérios que conduziram nossas decisões metodológicas.

O Capítulo II - Premissas culturais e manifestações linguísticas: aspectos metodológicos para a análise da (des)cortesia e demais papéis pragmáticos estabelece uma ponte entre o estudo das manifestações linguísticas da cortesia e as premissas culturais, que constituem aspectos das atitudes dos falantes, com base nos quais são produzidos os enunciados de uma interação. Fundamentado na Pragmática sociocultural, este capítulo busca abrir novos horizontes para os estudos interdisciplinares e holísticos de um corpus e para descrição do uso linguístico. Por isso, apresenta uma proposta metodológica para estudos de pragmática contrastiva que possa examinar a complexidade dos fenômenos da interação oral e a variedade de componentes socioculturais que intervêm em uma situação comunicativa. Neste capítulo também, apresentamos e descrevemos detalhadamente o corpus em que aplicaremos nossa proposta metodológica.

O Capítulo III - Descrição a partir do sistema sociocultural contempla três das quatro etapas da metodologia proposta no capítulo anterior: o enfoque interdisciplinar, a análise do corpus oral e a aplicação de testes de hábitos sociais. Em primeiro lugar, realizamos uma intersecção entre a Pragmática e outras disciplinas sociais, a fim de descrever aspectos da idiossincrasia das comunidades de fala e suas características de formação sociocultural e 
ideológica com o objetivo de estabelecer as necessidades e componentes da imagem social básica dos falantes. Em segundo lugar, examinamos o corpus para identificar aspectos linguísticos, comunicativos e conversacionais, através da análise dos atos de fala no discurso e as suas consequências imediatas. Neste momento, estendemo-nos ao contexto da enunciação, evidenciando e ratificando os fatores sociopragmáticos, situacionais, individuais e interacionais cujas pistas foram levantadas na etapa anterior. Finalmente, na terceira etapa, formulamos e aplicamos os chamados testes de hábitos sociais através dos quais buscamos apoio para as interpretações obtidas na análise do corpus e no levantamento bibliográfico interdisciplinar, a fim de corroborar as características da imagem social e dos valores culturais subjacentes ao comportamento cortês.

O Capítulo IV - O Contraste Cross-cultural: exposição e fundamentação dos resultados apresenta a quarta etapa da metodologia que propusemos. Nesta seção, os dados da análise são interpretados e são contrastadas as variações linguísticas e socioculturais entre as comunidades de fala em estudo.

Nas Conclusões, tratamos da validade científica dos aspectos metodológicos que apresentamos e aplicamos. Além disso, considerando os objetivos mencionados nesta introdução, discutimos os resultados, além de suas projeções, e evidenciamos as respostas às perguntas iniciais desta pesquisa. 


\section{CAPÍTULO I \\ A CORTESIA}

\section{A CORTESIA E ASPECTOS PRAGMÁtICOS: UMA PERSPECTIVA SOCIOCULTURAL}

Queremos abordar nesta tese o estudo dos princípios que regem o uso da linguagem na comunicação, ou seja, as condições que determinam tanto 0 emprego de um enunciado concreto por um falante em uma situação comunicativa concreta, como a sua possível interpretação por parte do ouvinte. Substancialmente, dessas atividades se ocupa a Pragmática (Escandell-Vidal, 1993: 15-16), que é tradicionalmente definida pelo estudo do uso linguístico (Levinson, 2007).

O modelo de análise proposto pela Pragmática é constituído por uma classe de elementos que configuram a situação comunicativa. Entre os componentes materiais, destacamos alguns conceitos chave que empregaremos nesta pesquisa: compõem no corpus, por exemplo, produções de falantes em situações comunicativas específicas e devemos dizer que entendemos como falante o sujeito que tem conhecimento de uma língua particular e faz uso da palavra em um determinado momento de enunciação, em uma interação verbal; de igual modo, o ouvinte é o indivíduo a quem o falante direciona o seu enunciado, com quem pode intercambiar o seu papel na comunicação dialogal. Também é aquele que possui a capacidade abstrata de compreender um determinado código 3 .

Nossa unidade de análise será o enunciado, que constitui a expressão linguística que produz o falante, ou seja, cada uma de suas intervenções que modificam o contexto. $O$ enunciado constitui uma sequência linguística concreta, realizada, pois, por um falante em uma situação comunicativa e é definido a partir de critérios discursivos.

\footnotetext{
3 Escandell-Vidal (1993: 27-39) estabelece uma oposição entre falante e emissor e entre ouvinte e destinatário, sustentando que os primeiros conceitos são melhor aplicáveis à gramática e à Análise da Conversação, e os segundos, à Pragmática. Neste trabalho, no entanto, adotamos os conceitos de falante e ouvinte uma vez que nosso estudo realiza uma interseção entre Pragmática e a Análise da Conversação, de que se tratará mais adiante.
} 
Especialmente no que diz respeito às trocas verbais, mencionaremos o conceito de turno, que, segundo o sistema de Sacks, Schegloff e Jefferson (1974), é um dos componentes centrais do modelo conversacional e é caracterizado por aquilo que um falante faz ou diz enquanto tem a palavra, incluindo o silêncio, ou seja, opõe-se ao enunciado por não constituir-se uma intervenção concreta.

O contexto, outro aspecto crucial em nossa análise, abrange o suporte físico no qual se realiza a enunciação e compreende elementos como as coordenadas de lugar e tempo. Contudo, o contexto se corresponde também à conceitualização do mundo feita pelos falantes, de modo que é determinado empírica, social e culturalmente. O contexto, vale ressaltar, não é algo externo aos falantes, mas faz parte das representações mentais que operam na comunicação e pode ser definido como o conjunto de representações que levam em consideração o falante, no momento em que emite seus estímulos, e o ouvinte, no momento em que os interpreta (Escandell-Vidal, 1993: 27-39). Vamos detalhar mais esse aspecto na seção seguinte, segundo o sistema sociocultural.

Para a análise do no corpus, devemos delimitar 0 termo intenção comunicativa através da relação entre 0 falante, o ouvinte e 0 contexto. A intenção comunicativa se relaciona com a ideia da direção, de tendência, de esforço por conseguir algo e manifesta a sua orientação para a consecução de uma determinada meta. À vista disso, devemos levar em consideração que esse recurso controla a conduta comunicativa do falante, na medida em que o conduz a utilizar determinados meios para alcançar o seu fim. Salientamos, assim sendo, que o termo intenção não deve ser entendido nesta pesquisa em sua acepção subjetiva ou psicológica, como a volição consciente ou motivação.

Finalmente, cabe-nos definir o conceito de relação social que abordaremos em nossa análise. A relação social entre os interlocutores, segundo Escandell-Vidal (1993), é determinada por fatores físicos como idade, sexo, etc., e sociais, como poder relativo, autoridade, etc. Devemos relembrar que a (des)cortesia é relativa a cada grupo que se diferencia linguística, geográfica ou socialmente e está intimamente unida com a ideologia e o poder. Este se atualiza na relação social que se refere à organização humana como 
uma estrutura social, ou seja, denota o grau de relação social entre falante e ouvinte.

Para este trabalho, especialmente, na análise do corpus oral, nos atentaremos também às relações que se estabelecem entre os estudantes dos grupos de estudos acadêmicos a partir do indivíduo que demonstra mais saberes e conhecimentos com relação ao tema central do encontro. E, por conseguinte, como se dá o trabalho de face e como se compõem as imagens sociais através dos papéis que desempenham os interlocutores nessas situações específicas.

Como vimos, o falante, o ouvinte, o contexto e o enunciado, pois, são elementos fundamentais nas relações estabelecidas durante uma interação verbal, na qual também desempenham um importante papel a intenção comunicativa, a distância social e a relação hierárquica entre falante e ouvinte. Salientamos, portanto, que como objetivo central, a Pragmática enfoca os fatores que determinam os intercâmbios comunicativos.

A propósito, o critério básico da Pragmática é o da adequação (EscandellVidal, 2005), uma vez que, em interações verbais, os participantes adotam papéis relativos à posição do outro (Goffman, 1961), papéis que variam de acordo com a dinâmica da situação comunicativa e conforme a maneira como cada interlocutor se situa durante a progressão do diálogo. Nesse âmbito, existem expectativas de adequação dos comportamentos à situação e aos papéis dos interlocutores. Essas expectativas nascem, em certo grau, de modelos sociais compartilhados entre os integrantes de um grupo.

Seguindo as propostas de Diana Bravo (2002b, 2004a, 2010), reconhecemos que a interpretação do fenômeno da (des)cortesia pode variar segundo fatores contextuais, em contrapartida às teorias fundadoras (Lakoff, 1973; Leech, 1983; Brown e Levinson, [1978]1987) que não se concentram no componente sociocultural dos estudos da (des)cortesia.

Do ponto de vista dessas teorias, chamadas por Diana Bravo (2010: 20) de tradicionais, o falante é considerado um agente racional que emite um enunciado do qual é inferido o que se deseja dizer a partir do que foi realmente 
dito (Grice, 1975; Sperber \& Wilson, 19864). Nesse modelo, sabe-se que para realizar essas inferências, os falantes compartilham um conjunto de conhecimentos, crenças, pressupostos, opiniões e sentimentos durante a intervenção verbal, além do código linguístico e características da situação comunicativa.

Nesse sentido, Bravo (2010) conclui que certamente os analistas podem apresentar dificuldades para interpretar a (des)cortesia se não pertencem à mesma comunidade de fala dos falantes que participam das interações verbais que compõem seu objeto de estudo. Em muitos estudos realizados não são consideradas informações socioculturais ou não são explicitadas a ponto de evitar-se que muitas estratégias de cortesia sejam classificadas como ameaçadoras, sendo justificadas pelas necessidades da imagem social universais do modelo de Brown e Levinson ([1978] 1987).

Sendo assim, na presente tese, buscamos uma perspectiva sociocultural, uma postura que considere o contexto de enunciação das intervenções dos falantes do material de análise e que reconheça que a interpretação da (des)cortesia depende de fatores contextuais aos quais o analista deve ter acesso. Por isso, reafirmamos 0 abandono às teorias etnocentristas e, à vista disso, valorizamos as propostas metodológicas que reconhecem a necessidade de valorizar o contexto do usuário de uma língua, dando ao elemento extralinguístico o status de instrumento de análise (Bravo, 2009).

Pela Pragmática formal e tradicional os analistas justificam a interpretação da (des)cortesia em seus próprios conhecimentos, recurso que Diana Bravo (2010) chama de introspecção, no entanto é necessário obter acesso ao contexto do usuário, suas intuições e percepções.

$\mathrm{Na}$ Pragmática sociocultural, os analistas optam por combinar as suas próprias intuições e experiências comunicativas ao recolhimento de percepções dos usuários da língua em estudo. Esta etapa Diana Bravo (2010) chama de consulta, momento cuja finalidade é que o analista tenha acesso, mediante

\footnotetext{
${ }^{4}$ Cabe-nos ressaltar que Sperber e Wilson (1986), citando a Grice, revisam esquemas de comunicação e apresentam um modelo pragmático, cujos processos que intervêm são baseados na ostensão e na inferência. A ostensão é o processo pelo qual o emissor busca chamar a atenção do destinatário, produzindo algum tipo de indício de modo intencionado. A inferência é o processo pelo qual o destinatário relaciona as informações procedentes de fontes diferentes (linguísticas e não linguísticas) com a finalidade de reconstruir as representações que o emissor pretende transmitir-lhe. As representações, por sua vez, são as entidades mentais que desempenham algum papel na comunicação, seja como material de entrada ou como material contextual.
} 
instrumentos de pesquisa, às premissas culturais e as impressões dos falantes nativos, para evitar interpretações etnocentristas.

Isto posto, vemos que a Pragmática sociocultural oferece instrumentos de análise adequados para a interpretação da cortesia na comunicação intercultural e em estudos cross-culturais. E leva em consideração o que é o centro de interesse deste estudo: a cortesia e a conversação coloquial ${ }^{5}$, especificamente 0 subgênero grupo de estudo, bem como a negociação e a construção da imagem com relação às atividades de cortesia em distintos âmbitos culturais.

\subsection{Das teorias fundadoras dos estudos da cortesia ao modelo sociocultural}

É conveniente proporcionar aqui os antecedentes e pressupostos dos estudos da cortesia além de, diante do desenvolvimento de diferentes correntes teóricas que abordam o tema, apresentar quais são as propostas para o estudo sociocultural da cortesia, em contraste com as primeiras gerações que se afiliaram a uma perspectiva universalista.

Os estudos da cortesia mediante a Pragmática sociocultural, como mencionado anteriormente, incorporam o contexto do usuário da língua, observado e analisado a partir da perspectiva da linguagem. Nesse sentido, todos os elementos referentes à situação comunicativa são levados em consideração. A Pragmática sociocultural dá ao fator extralinguístico, por conseguinte, uma categoria de análise, a fim de estabelecer o fluxo de interdependência entre linguagem e sociedade (Bravo, 2005).

Reiteramos que o contexto sociocultural, do qual partilham os falantes de uma comunidade de fala, conduz a interpretação de (des)cortesia, de maneira que neste se fundamenta a inferência dos usuários da língua. Portanto, o acesso ao contexto é essencial para poder classificar a função de expressões de (des)cortesia no estudo de discursos orais.

\footnotetext{
${ }^{5}$ A conversação coloquial consiste um tipo de registro informal, cujas características são a espontaneidade, a naturalidade e a falta de planejamento verbal. Quanto às suas características situacionais, também encontradas no corpus da presente pesquisa, destacam-se: a relação de igualdade entre os interlocutores, a relação de proximidade e o marco discursivo familiar (Briz, 1998, 2001).
} 
Referimo-nos a contexto sociocultural, conforme Bravo (2005), quando tratamos das características presentes na própria interação interpessoal até das peculiaridades da comunidade de fala, que incluem: características do grupo, as relações sociais, a classe socioeconômica, os fatores culturais como o conhecimento compartilhado, as crenças e os valores, os fatores demográficos e sociais como idade, sexo e educação, o lugar de residência e a identidade étnica e nacional. Sempre levando em conta a possibilidade de variações interculturais, intraculturais, situacionais e até mesmo interpessoais ou individuais. São todos esses os fatores que permitem ao analista estabelecer uma conexão entre os enunciados e a realidade social.

Em contrapartida à inclusão do elemento sociocultural aos estudos da cortesia, Brown e Levinson ([1978] 1987) foram os autores que cunharam a noção de universalidade a partir de dois aspectos: a face negativa, que constitui o desejo de liberdade de ação, de não imposição e de domínio do próprio território; e a face positiva, que corresponde à imagem que o indivíduo tem de si mesmo, ao anseio de ser aceito pelo outro e de que os outros compartilhem dos mesmos desejos. Retomando e sistematizando assim os estudos de Goffman (1970), conforme Brown e Levinson, todo indivíduo preserva em si mesmo certa imagem pública ou reputação que determina os comportamentos sociais e as estratégias de cortesia.

Aqui, registramos que valorizamos o alto grau explicativo das categorias no modelo de Brown e Levinson, entretanto, seu "etnocentrismo sociocultural" e a sua insuficiência ao estabelecer parâmetros panculturais contrastam com o modelo sociocultural. Isto posto, questiona-se a validade do aspecto universal ${ }^{6}$

\footnotetext{
${ }^{6}$ Muitos autores realizaram estudo e críticas ao modelo de Brown e Levinson, por ser etnocentrista com perspectivas exageradamente anglocêntricas (Mao (1994); Matsumoto (1988), Ide (1989), O’Driscoll (1996)); por não considerar o fenômeno da descortesia (Culpeper (1996)); por fundamentar-se na teoria griceriana dos atos de fala (Arundale (1999)); por possuir uma orientação normativa pouco clara (Eelen (2001)); e por não se estabelecer um consenso entre os estudiosos sobre o sentido do binômio positivo/negativo (face - estratégias corteses) (Fant e Granato, 2002). Mao (1994) e Matsumoto (1988) são as mais citadas referências críticas ao modelo de Brown e Levinson. Estes autores questionam a universalidade dos aspectos negativo e positivo da imagem social. Mao (1994), especificamente chama a atenção para os componentes da imagem chinesa; descreve a imagem de respeito do grupo com relação a um indivíduo com boa reputação moral e a imagem de prestígio que são atribuídas a um indivíduo por outros. Para Mao, a imagem negativa não tem representação na cultura chinesa ao passo que no modelo de Brown e Levinson, a cortesia se identificaria por supervalorizar o indivíduo, no lugar do grupo. Matsumoto (1988), pesquisadora japonesa, por sua vez, enfatiza o caráter coletivo das culturas asiáticas, de maneira que pouco valor é atribuído às imagens individuais nessas culturas, de modo que a autonomia não possui um papel crucial na interação social. Questionando também aspectos do modelo de Brown e Levinson, Blum-Kulka et. al. (1989) valorizam as diferenças presentes entre culturas ao analisar atos de pedir e
} 
das noções de pessoa, cortesia, imagem social e das ameaças a essas imagens, positiva e negativa, apresentadas por esses autores.

Cada língua possui uma convenção parcial das intervenções da cortesia, o que implica dizer que cada cultura torna subjetivo o uso de determinados mecanismos linguísticos para manifestá-la (Haverkate,1994) ${ }^{7}$. Assim, por exemplo, em conversações entre acadêmicos argentinos, Bravo (2004b: 30) observa que estes não levam em conta o território pessoal (imagem negativa), pelo contrário, os interactantes buscam compartilhar as próprias experiências e a de outros interlocutores. Em situações semelhantes na Espanha, igualmente, não se manifesta a preocupação com o território pessoal, procura-se tratar o interlocutor de maneira familiar e alcançar níveis de familiaridade e sociabilidade.

Dessas correlações, podemos ver, como afirma Bravo (2004b), que as categorias de imagem positiva e imagem negativa dão conta de valores corteses, não consideram as relações interpessoais, tampouco levam em consideração que a interpretação da cortesia depende de fatores de ordem contextual. Portanto, sustentamos que essas categorias não podem ser utilizadas em estudos interculturais ou contrastivos, porque nem todas as sociedades são concebidas como no modelo de Brown e Levinson.

Se realizarmos um retrocesso temporal, a fim de buscar uma breve visão panorâmica dos estudos da cortesia, encontraremos mais argumentos que advogam pelo fato de que o modelo universalista não pode ser aplicado a estudos interculturais que abordam a cortesia linguística.

Como já exposto, os textos fundacionais dos estudos linguísticos da cortesia se encontram nas publicações de Grice (1975), Leech (1983), Lakoff (1973), que formularam máximas, e Brown e Levinson ([1978] 1987) que desenvolveram o termo face, introduzido por Goffman (1970), para definir o conceito de imagem do homem como membro da sociedade. Descreveremos

desculpar-se. Comprovam que não é universal o fato de que em todas as culturas os atos diretivos devem, por necessidade, serem enunciados de maneira indireta, por sempre representarem uma ameaça à face negativa do interlocutor. Blum-Kulka et. al. demonstram que as diferenças entre o uso de atos (in)diretos são subjacentes às características da situação comunicativa, aos distintos níveis de convenções e aos valores sociais atribuídos a tais atos.

${ }^{7}$ Haverkate (1994), a partir do ponto de vista pragmalinguístico, fundamenta-se nas teorias dos atos de fala de Searle (1969), nas máximas conversacionais de Grice (1975), nas de Leech (1983), na cortesia verbal de Brown e Levinson ([1978] 1987) e na teoria da Relevância de Sperber e Wilson (1986). O autor evidenciou a importância do contexto situacional para a correta interpretação de um enunciado (des)cortês, contrastando a cultura espanhola e holandesa. 
aqui brevemente alguns desses modelos a fim de reiterar nossa posição de que teorias tradicionais não podem ser aplicadas a estudos interculturais ou contrastivos da cortesia linguística.

Os estudos de Lakoff (1973) proporcionaram informações sobre a atualização empírica da cortesia, apresentando três estratégias verbais de que se vale um falante cortês, formuladas em forma de máximas: "não importune"; "ofereça alternativas"; e "faça com que o ouvinte sinta-se bem, comporte-se amigavelmente".

Os estudos de Grice (1975)르. seu Princípio de Cooperação e a existência das implicaturas, unidos à necessidade de justificar os atos de fala indiretos, evidenciam os componentes sociais de uma interação. No seu modelo, o não cumprimento das máximas de quantidade, qualidade, relação e modo, segundo analistas posteriores a sua publicação, dão lugar às estratégias de cortesia.

Leech (1983) considera que o princípio de cortesia age mais na conversação que as máximas de Grice, de maneira que as amplia com um novo sistema de máximas: a de tato, a de generosidade, a de aprovação, a de modéstia, a de unanimidade e a de simpatia. Leech assevera que os princípios de cooperação e de cortesia são universais, entretanto reconhece algumas diferenças sociais na interpretação da (des)cortesia. Apesar disso, não se aprofunda nesse aspecto intercultural.

Em resumo, através da cortesia, segundo essas visões apresentadas, os interlocutores de uma conversação não se impõem, dão opções, apresentam tato, são generosos e maximizam os benefícios, minimizam as ofensas (Lakoff, 1973; Leech, 1983). A variedade presente nas interações sociais, portanto, não é considerada nesta perspectiva que tem como foco formas fixas de comportamento linguístico.

Nesses modelos, o papel do ouvinte é passivo, configura-se como intérprete das intervenções do falante que detém o papel central. E concentram a sua metodologia na imagem negativa, nas ameaças e nas chamadas

\footnotetext{
${ }^{8}$ Grice descreveu o Princípio de Cooperação que expõe que contribuições conversacionais devem ser adaptadas ao caráter e ao objetivo do intercâmbio verbal do qual se participa. Este princípio compreende as categorias de quantidade, qualidade, relação e modo, as quais são caracterizadas respectivamente pelas submáximas: "Faça que sua contribuição seja tão informativa quanto for requerido (para o propósito corrente da conversação)", "não diga o que você acredita ser falso", "seja relevante e "seja claro". Tais submáximas, neste modelo, podem ser burladas, produzindo as chamadas implicaturas, que servem frequentemente como estratégias de cortesia.
} 
estratégias negativas, que são realizadas para protegê-la. Em outras palavras, a atividade estratégica consiste em uma atividade destinada a atenuar as ameaças. Logo, todas as estratégias de cortesia teriam que ser atenuadoras, premissa que não pode ser fundamentada.

Nessa visão, igualmente, um contato social corresponderia a um risco à imagem do falante e do ouvinte, devido à potencial invasão da territorialidade por parte de um dos interactantes. Assim, o falante suavizaria essa ameaça através de procedimentos corteses, se não desejasse ameaçar a imagem social. Os interlocutores então, buscando o equilíbrio, protegem a sua própria imagem e a do outro.

Lembramos que no modelo de Brown e Levinson existe uma necessidade de reparar-se a ameaça ou a agressividade que qualquer contato social pressupõe. Para os autores, portanto, a maior parte dos atos de fala que são realizados na vida cotidiana seriam potencialmente ameaçadores. Tratam-se dos chamados atos ameaçadores da face (FTAs: face threatening acts).

Como essa concepção é excessivamente redutora, Kerbrat-Orecchioni (1992,1996, 2005) apresenta uma das propostas que surgiram para a valorização do componente sociocultural. A autora proporcionou uma nova reflexão sobre a existência dos chamados FFAs (face flattering acts) ou atos que reforçam a imagem:

a polidez ${ }^{9}$ consiste também em produzir "antiameaças": se um grande número de atos de linguagem são de fato ameaçadores para as faces dos interlocutores, alguns deles, ao contrário, tendem a ser mais valorizadores para essas mesmas faces, como o elogio, o agradecimento ou os votos - ainda bem, pois não somente as faces pedem para ser preservadas, mas também, às vezes, elas esperam gratificações mais positivas (...) (Kerbrat-Orecchioni, 2005: 88)

Esse termo se refere a um ato valorizador ou elogioso da imagem, considerando que de uma sociedade a outra, os comportamentos de cortesia variam consideravelmente e, do mesmo modo, variam as situações em que convém ser cortês e aquelas em que a cortesia não seria adequada.

\footnotetext{
${ }^{9}$ Nesta citação, entende-se polidez por cortesia. Nesta tese empregamos o conceito de cortesia, embora consideremos ambos os conceitos como sinônimos.
} 
Antes, Fraser (1980, 1990), já havia colocado foco na atividade interpessoal de conversação, quando afirmou que a cortesia se manifesta com base em um contrato conversacional que reflete os direitos e as obrigações mútuas das pessoas que interagem numa conversação. No entanto, devemos considerar que esse contrato também está sujeito a alterações segundo a compreensão que os participantes tenham da própria situação comunicativa, dado que o encontro comunicativo é dinâmico e o contrato conversacional precisa ser implementado socioculturalmente (Bravo, 2004a).

Depois de ter traçado os delineamentos da corrente sociocultural em contraste com os modelos tradicionais, finalmente podemos delimitar nosso objeto de estudo, a cortesia, através da proposta de Diana Bravo (2004a: 5-6) que a denomina "cortesia linguística, comunicativa, conversacional e estratégica".

Linguística, porque, embora outras ciências e disciplinas sociais se interessem pela cortesia, através da Pragmática, a cortesia é um objeto de estudo da linguística; comunicativa, pois a cortesia é objeto de estudo das ciências da linguagem em geral, o que inclui, com obviedade, a linguística, isto é, a cortesia pertence à comunicação e quando se manifesta mediante o sistema da linguagem, pertence à linguística (Bravo, 2005); conversacional, posto que esta delimitação se relaciona ao fato de que a interação "modelo" em que se aplica esse tipo de cortesia, em sua forma mínima, é o diálogo; e estratégica, uma vez que esse conceito depende de escolhas livres do falante no contexto da situação de fala em que se produzem e, portanto, a cortesia estratégica é volitiva e contrasta com a cortesia ritual e normativa, que se refere a expressões comunicativas altamente convencionais e que têm um caráter fixo na língua.

A conhecida denominação verbal, para cortesia verbal, não será utilizada neste estudo porque esta é mais relacionável a palavras e sinais suprasegmentais que intervêm na emissão de uma oração, de maneira que pode delimitar-se ao fator estritamente linguístico. Entretanto, como já notabilizado, a visão pragmática empreendida aqui considera ao mesmo tempo os fatores extralinguísticos presentes no material de análise, os quais determinam o uso da linguagem. 


\subsection{A definição das categorias de imagem social e aspectos teóricos}

Como descrevemos anteriormente, Goffman (1970) delimitou o termo face ou imagem social e sustenta que os indivíduos estão emocionalmente comprometidos com uma imagem de si mesmos que é aprovada pela sociedade e que dá lugar a uma serie de regras para o contato interpessoal. Segundo o autor, o trabalho de face (o chamado face work ou, no caso de estudos hispânicos, actividad de imagen) institui todas as ações do indivíduo que tenta impedir a perda de qualquer imagem, as suas e as do outro. A esse trabalho de face, Brown e Levinson dão o nome de cortesia. Por conseguinte, criam um extenso catálogo de estratégias de cortesia destinadas a atenuar o efeito social negativo.

Nesse sentido, os Brown e Levinson propuseram os conceitos de cortesia positiva e cortesia negativa. Lembramos que a primeira corresponde a uma compensação dirigida à imagem positiva do ouvinte, de forma que a cortesia positiva é a essência do comportamento familiar e distendido. A cortesia negativa, por sua vez, é uma ação compensatória dirigida à face negativa do ouvinte. Este é o cerne do comportamento respeitoso (Brown e Levinson, [1978] 1987: 129).

A teoria de Brown e Levinson, no que diz respeito às imagens sociais e a questão da universalidade, por ter sido muito debatida, como já mencionamos neste texto, tiveram os aspectos de face revistos por alguns autores.

Sabemos que o trabalho de face pode variar de acordo com o estilo comunicativo próprio e a situação ou um contexto social restrito a uma determinada cultura. Levando isso em consideração, a dualidade da imagem social proposta por Brown e Levinson foi, pois, re-explorada por Diana Bravo (2002b) que discute se é válido afirmar que os conteúdos dos aspectos positivo e negativo dão conta de uma face social universal; a autora indica a existência de conteúdos básicos que compõem e descrevem a imagem daqueles indivíduos que pertencem ao mesmo grupo. A autora caracteriza então a imagem social, relacionando comportamentos comunicativos a contextos socioculturais. 
Bravo (2002b) reapresenta e descreve ${ }^{10}$ as categorias de imagem social: a de autonomia e a de afiliação. A imagem de autonomia contempla o desejo do indivíduo de ver-se e ser visto como alguém com contorno próprio dentro do grupo, ou seja, refere-se ao que the diferencia deste. Os comportamentos de cortesia podem ser classificados conforme são orientados pela imagem de autonomia, mediante a qual um integrante de um grupo adquire um contorno próprio dentro do mesmo. A imagem de afiliação se refere ao desejo de ver-se e ser visto pelas características que o identificam com seu grupo.

Essas categorias são abertas e permitem a incorporação das características específicas de cada comunidade cultural, dado que a relação existente entre a imagem social e a cortesia não se constrói da mesma maneira em todos os grupos sociais, nem todos os grupos sociais concebem sua imagem social da mesma forma. Portanto, no que diz respeito às correlações mencionadas, não é possível criar-se categorias universais, mas sim instrumentos de avaliação que permitam a observação da relação entre 0 comportamento comunicativo, as crenças e a visão de mundo dos falantes.

O conceito de imagem básica se adapta à situação de fala, mediante ao seu deslocamento aos conteúdos da face que correspondem a papéis sociais e situacionais; assim sendo, Bravo (2002b) destaca a importância de considerar os contextos socioculturais como um referente natural para a explicação da força ilocutória dos enunciados e para compreender melhor o fenômeno da cortesia.

Segundo Briz (2004b: 67-68), os conceitos de autonomia e afiliação são traços essenciais para definir a cortesia e para reconhecer-se a maior ou menor adequação de uma contribuição cortês, assim como o êxito ou o fracasso da mesma.

Bravo (2002b) propõe que nas análises de corpus, o analista apresente conhecimento de certas convenções sociais dos falantes das línguas estudadas, ao que ela denomina de "premissas culturais". A partir desse conhecimento, será possível agregar outros componentes de imagem às imagens básicas.

A modo de ilustração, Bravo (2002b: 162-163) assegura que na cultura sueca é em alto grau apreciada a "imagem de independência", que constitui um

\footnotetext{
${ }^{10}$ Fant (1989), Scollon e Scollon (1995) e Kerbrat-Orechioni (1994) traçam os primeiros passos na definição das imagens de afiliação e/ou autonomia.
} 
componente básico da imagem de autonomia dessa comunidade de fala. Também afirma que os conteúdos de "originalidade" e "generosidade" fazem parte da imagem básica estendida por toda a sociedade a que pertence, a argentina (Bravo, 2004b: 28).

Os conteúdos de imagem

surgen de la formulación de un valor cultural, pero no se trata de describirlos mediante términos que en sí mismos no dan cuenta de los sentidos socio-culturales para luego trasladarlos de una cultura a otra. La función de estas categorías de imagen de autonomía (verse/ser visto diferente de otros) y de imagen de afiliación (verse/ ser visto en su identificación con el grupo), no excede la de abarcar contenidos de imagen de acuerdo con la caracterización de cada una. Es la determinación de los mismos, mediante la observación de la relación entre comportamientos comunicativos y premisas culturales, lo que, en realidad, provee de información acerca de los rasgos que describen a una imagen social y a sus concretas diferencias con la de otras culturas. (Bravo, 2002b: 164)

Como vimos, as imagens de autonomia e afiliação não devem ser utilizadas como categorias de análise fixas, na verdade, a categorização e a determinação dos conteúdos da imagem básica proporcionarão informações sobre uma determinada imagem social e evidenciarão sua diferença com a imagem de outra cultura. Segundo Bravo (2002b), conseguimos definir tais componentes da imagem básica através da observação da relação entre 0 comportamento comunicativo e as premissas culturais, levando em consideração que tais conteúdos socioculturais fazem parte das premissas culturais de uma comunidade de fala.

Buscando um maior detalhamento dos conteúdos de imagem, notamos que estes correspondem aos papéis sociais, isto é, à posição que desempenham os interlocutores, com relação aos outros (Bravo, 2002b: 164167).

O papel social é designado segundo circunstâncias sociais, como resultado de uma atribuição; temos o papel de mãe e filho, médico, paciente, jovem, idoso, etc. No geral, tratamos de pares de papéis sociais, dado que suas características são definidas com relação ao outro em uma interação (Bravo, 2002b: 165). 
Buscando integrar a perspectiva de Bravo (2002b) a outras, evidenciando a identificação dos conteúdos da imagem básica, observamos que precisamos de critérios teóricos para descrevê-los quanto aos papéis sociais que podem representar. Encontramos em Fant e Granato (2002) um modelo de análise que coloca em relevo os papéis dos interlocutores em situações comunicativas específicas que nos oferece instrumentos de análise fiáveis.

Fant e Granato (2002) relacionaram o conceito de identidade com o de face, de modo que subcategorizaram também o conceito de imagem social. Esse modelo foi criado também em resposta às conhecidas e referidas críticas feitas ao modelo de Brown e Levinson. E segundo a linha metodológica que é definida aqui, pode ser utilizado em conjunto com o modelo de Diana Bravo (2002b) na análise da manifestação da (des)cortesia linguística.

Fant e Granato (2002) buscam relacionar e considerar fenômenos como: a atribuição de identidade coletiva e individual; as atividades de gestão interrelacional; as necessidades da face; as metas ou planejamentos pessoais; os direitos e obrigações sociais.

Propõem, pois, uma visão co-construcionista da interação humana e partem de uma conceitualização teleológica das atividades comunicativas, associando a teoria da cortesia com contribuições de Spencer-Oatey (2000), cujas publicações se fundamentam na psicolinguística.

Segundo essa visão co-construcionista, o sujeito falante, ao planejar seu enunciado, faz uma avaliação sobre como será a recepção da sua mensagem pelo interlocutor com relação à escolha do código, à formação do significado frástico, à apresentação ilocutória e à relação que é estabelecida com o interlocutor. É nesse último ponto no qual ocorrem os mecanismos de cortesia.

A partir da visão teleológica, na qual se fundamenta o modelo de Fant e Granato (2002), a análise da cortesia deve estar orientada às finalidades e efeitos dos atos de fala, de maneira que nas análises de corpus é importante detectar quais são os fins dos interactantes ao utilizarem as suas ferramentas comunicativas e o que conseguem com elas. Da mesma forma, Fant e Granato (2002) consideram essencial tentar discernir os efeitos que tem 0 ato de um interactante sobre o contexto em que se encontra.

No que diz respeito à elaboração da identidade através da interação, Fant e Granato (2002) distinguem cinco componentes da imagem social. Esses 
diversos aspectos da face partem da necessidade do indivíduo de preservar e defender o fato de pertencer a um grupo (Fant e Granato, 2002: 13):

1) Imagem de semelhança: pelo fato de pertencer a um grupo permanente ou transitoriamente, é necessário que o indivíduo projete certo grau de semelhança com os outros membros; se isso não ocorre, há a ameaça de uma exclusão;

2) Imagem de cooperação: um objetivo social primordial é mostrar-se como membro cooperativo; se isso não ocorre, há a ameaça de uma exclusão; Gestão da autoimagem: apresentar-se como uma pessoa cooperativa, disposta a ajudar ou respaldar os demais ou pelo menos renunciar a interferir com os planejamentos alheios;

3) Imagem de excelência: o indivíduo sente a necessidade de projetar as suas boas qualidades, entendidas como atribuições, etiquetas ou categorizações dotadas de valor positivo; a importância dessa projeção radica nos sistemas prescritivos de valores sociais; se o indivíduo falha, corre o risco de ter reduzido o seu direito de pertencer ao grupo ou ver-se excluído do mesmo;

4) Imagem de papel ou de identidade interrelacional: é a relação entre as normas que regem a gestão interrelacional e o papel assumido em um contexto específico;

5) Imagem de hierarquia: se associa ao grau de poder, à influência e ao status de um indivíduo no contexto da interação;

Os diversos tipos de atos destinados a sinalizar uma atitude de respeito, de distanciamento, de não imposição ou de não aproveitamento diante do interlocutor - atos etiquetados de cortesia negativa no marco de Brown e Levinson ([1978] 1987) - são vistos por Fant e Granato (2002) como orientados diretamente a sistemas de direitos e obrigações e, somente de maneira indireta, a sistemas de imagem social. 
Por tudo o que foi exposto, vê-se a necessidade de priorizar, neste trabalho, algumas categorizações de Fant e Granato (2002: 21-25), que indicam algumas dimensões fundamentais na gestão interrelacional como: as atividades construtivas e destrutivas; as estratégias afirmativas e evitativas; e atividades alo- e autocêntricas.

Para referir-se a atividades de tipo cortês, utilizaremos a subcategoria atividades construtivas e atividades destrutivas, que se associa ao tipo descortês, dado que o binômio positivo/negativo poderia ter o significado de cortesia versus descortesia para um leitor pouco especializado na área. $O$ fenômeno da defesa territorial - da imagem negativa, segundo Brown e Levinson ([1978] 1987) - está vinculado fundamentalmente a sistemas de direitos psicossociais e não a sistemas de imagem social, como acabamos de ver, por conseguinte, o binômio - positivo/negativo - não é aplicável na classificação das atividades de cortesia.

Igualmente, portanto, as interações entre falante e ouvinte(s) não está baseada, em todas as comunidades de fala, em que o falante busca suavizar o tempo todo a sua imposição, protegendo a imagem negativa do interlocutor e, também, em manter a autoestima do interlocutor, protegendo assim a sua imagem positiva, para ser aceito pelos demais, o que promoveria procedimentos de atenuação.

O rigoroso paralelismo entre face positiva e face negativa de um lado, e cortesia positiva e cortesia negativa, por outro - com a ideia de que as estratégias corteses positivas se orientariam à preservação da face positiva e as estratégias negativas, à face negativa -, não considera que um mesmo ato pode ser interpretado como "positivo" e "negativo", simultaneamente.

Para evitar essa imprecisão, utilizaremos nesta pesquisa as categorias de estratégias afirmativas, cuja meta seja proteger e fortalecer ativamente a alo- ou autoimagem, versus estratégias evitativas, que buscam evitar a ameaça da imagem do outro ou do Eu.

Com relação à descortesia, igualmente cabe a mesma oposição. Um ato descortês afirmativo atenta contra algum aspecto significativo dos direitos sociais ou busca ameaçar a imagem social do interlocutor. Por sua vez, um ato descortês evitativo poderia ser visto como a ausência de um ato cortês que 
correspondesse a uma expectativa situacional, pela qual, uma meta, direito ou imagem são afetados.

$\mathrm{Na}$ gestão interrelacional, as atividades autocêntricas estão orientadas aos interesses do sujeito falante e/ou ao grupo que representa, e as atividades alocêntricas, orientadas aos interesses do interlocutor e/ou ao grupo que representa. Estas subcategorias se instituem devido a que nas atividades de cortesia, por exemplo, faz-se referência a atos alocêntricos, isto é, de promoção da aloimagem, metas e desejos do outro.

Essa nova perspectiva se aplica às atividades de gestão interrelacional e se manifestam nas interações humanas em geral, como no corpus da presente pesquisa.

No âmbito das subclassificações na teoria da cortesia, Charaudeau (2012) também analisa algumas questões teóricas e metodológicas que têm permeado os estudos da cortesia e, ainda, apresenta aspectos linguísticos, pragmáticos e discursivos que intervêm nos intercâmbios verbais, propondo uma nova classificação dos atos interacionais.

No que diz respeito ao marco geral dos fatos de comunicação, esse autor estabelece a crítica de que as pesquisas devem progredir mais além das análises de corpus, no entanto, com bases nestas, as pesquisas devem buscar compreender o que está em jogo nos estudos discursivos e determinar qual é a sua utilidade para os estudos linguísticos de um modo geral. Igualmente assevera que não é adequado reduzir ou estandarizar todas as estratégias discursivas de controle à cortesia perdendo de vista a diversidade das interações verbais (Charaudeau, 2012: 14-15).

Nesse sentido, lembramos que esta pesquisa visa a realizar uma análise descritiva e contrastiva das estratégias linguísticas e discursivas de cortesia em um corpus em português e outro em espanhol, no entanto, a indagação deste estudo é contribuir para descrição de estratégias que objetivam manter o equilíbrio na interação social nos encontros estudantis, levando em conta as diferenças específicas de cada contexto e outras atividades de imagem, que não necessariamente manifestam cortesia. 


\subsection{Os atos de fala dentro do modelo sociocultural}

Os parâmetros de análise elencados por Haverkate (2004), a partir do ponto de vista metodológico que abarca a interpretação da cortesia com base em parâmetros socioculturais, são muito válidos para descrever e contrastar as estratégias de cortesia em português e espanhol, na negociação acadêmica. Em especial quanto à análise da manifestação da cortesia nos enunciados dos usuários de ambas as línguas com vistas a estabelecer generalizações sobre as estratégias comunicativas e os modos de formulação em determinados atos de fala ${ }^{11}$.

Para o estudo da dimensão contrastiva do processo comunicativo, isto é, para a análise comparativa da cortesia, Haverkate (2004) apresenta o potencial analítico de alguns parâmetros pragmalinguísticos a fim de comparar elementos culturais, com foco na caracterização do caráter positivo ${ }^{12}$ da cortesia.

Haverkate (2004: 56-64) expõe uma tipologia de atos como um modelo de análise contrastiva entre culturas: atos de discurso, atos paralinguísticos e atos metapragmáticos. Para o autor, vale ressaltar, os atos de fala representam um

11 Os atos de fala correspondem a fundamentais instrumentos de análise nesta pesquisa, portanto lembramos que Austin (1962) foi quem contribuiu para os avanços do estudo da linguagem e influenciou a área da Linguística e Filosofia da Linguagem com a sua teoria dos atos de fala. Segundo Austin, a linguagem não tem somente a função de descrever o mundo, mas também é empregada para "fazer coisas". E, em ciências da linguagem, tais conceitos se transformaram na base da abordagem pragmática. Considerando o uso da língua a partir da ótica da Filosofia da Linguagem, Austin observou que há um tipo de enunciado cuja emissão em certas condições equivale ao cumprimento da ação que impingem. A esses enunciados chama de performativos, os quais frequentemente correspondem a fórmulas ritualizadas como, por exemplo, "Eu peço desculpas". Nesse sentido, Austin formulou uma divisão geral dos atos de fala que são realizados por enunciados performativos ou não. Assim, classifica os atos de fala como: ato locucionário, que se realiza pelo fato de enunciar algo e corresponde ao significado linguístico; ato ilocucionário, que se realiza ao dizer algo de um modo determinado, possuindo certa força ou intenção; e ato perlocutório, que se realiza por dizer algo e se refere à forma como influencia o interlocutor; esse ato depende do ouvinte e alcança efeitos ou resultados.

Searle (1969) desenvolveu a teoria de Austin e sistematizou a noção de atos de fala com base na força ilocutória. Searle formulou o conceito de ato de fala indireto e reconheceu a importância do contexto nas interações verbais.

Com base na força ilocutória, Searle classifica os atos de fala em cinco categorias:

1) Representativos/ Assertivos: fazem com que o falante se comprometa com a mensagem (afirmar, concluir, etc.);

2) Diretivos: pretendem influir na conduta do interlocutor (pedir, perguntar, etc.);

3) Promissivos: condicionam a conduta ulterior do falante (prometer, ameaçar, convidar, etc.);

4) Expressivos: manifestam sentimentos ou atitudes do falante (agradecer, parabenizar, etc.);

5) Declarativos: modificam a realidade (batizar, declarar guerra, etc.).

${ }^{12}$ A distinção entre "culturas de cortesia negativa", que são orientadas pelo distanciamento interpessoal, e "culturas de cortesia positiva", que valorizam a solidariedade e familiaridade grupal, foi estabelecida por Brown e Levinson ([1978] 1987). No entanto, a presente pesquisa não utilizará as subcategorizações estabelecidas pelo tradicional modelo de Brown e Levinson como já esclarecido. 
elemento monologal não precisamente determinada pelo uso da linguagem, (Searle, 1969), porém os atos de discurso estão inseridos em uma situação comunicativa concreta e são, pois, uma ampliação do conceito de ato de fala. Mas para não contrastar com as demais correntes terminológicas usadas aqui, não adotaremos esse conceito, ou seja, utilizaremos o termo ato de fala.

Para esse modelo de análise, Haverkate (2004) seleciona três atos: assertivos, diretivos e expressivos.

O objetivo ilocutório do ato assertivo é definido mediante a intenção do locutor de assumir a responsabilidade pela verdade do que assevera. Para a análise comparativa de cortesia, a ironia e a repetição léxica possuem um papel distintivo. A repetição léxica pode ser produzida quando o falante reproduz as suas próprias palavras. Muitas vezes é uma estratégia de ênfase com o fim de insistir na importância de alguma informação ou ponto de vista, constituíndo-se assim a autorrepetição. Haverkate (2004) também destaca a expressão da conformidade total com algum ponto de vista apresentado pelo interlocutor, transmitindo cortesia, valorizando a imagens envolvidas quando se produz a heterropetição.

A ironia, por sua vez, é um recurso retórico e, dentro de modelo de análise, limita-se a analisar a ironia assertiva, estratégia através da qual 0 falante manipula o valor da verdade do que enuncia.

Os atos diretivos podem ser realizados com o fim de influir no comportamento intencional do interlocutor de forma que este realize a ação descrita pelo conteúdo proposicional do enunciado. Para o presente estudo, interessa-nos 0 ato de petição e 0 trabalho das imagens envolvidas, como também a cortesia estratégica.

Os atos expressivos manifestam sentimentos ou atitudes do falante, como a expressão de um estado psicológico. Para o estudo comparativo dos atos expressivos, Haverkate (2004) chama a atenção para o ato de lisonjear e para o ato de agradecer.

O agradecimento é bastante crucial na comparação entre as culturas, dado que agradecer não cumpre as mesmas funções em culturas diferentes. Como exemplo, na cultura espanhola peninsular não se valoriza, como em muitas regiões do Brasil, o agradecimento como resposta verbal a ações 
rotineiras efetuadas dentro de um padrão interrelacional pré-estabelecido, como a relação entre garçom e cliente, vendedor e comprador, etc.

A lisonja tem como objetivo ilocutório transmitir solidariedade e apreciação ao interlocutor, ressaltar os seus méritos e qualidades. Reforça, portanto, a imagem do outro. Cremos que esse aspecto é muito relevante para o estudos contrastivos, posto que é um fator que revela a valorização da distância ou da aproximação social entre os interlocutores.

Nesta pesquisa, os atos paralinguísticos também serão levados em conta na análise do corpus oral. Os atos paralinguísticos se bifurcam em atos cinésicos, como os gestos, e atos proxêmicos, que dividem o espaço físico entre os interlocutores no lugar onde se desenvolve a interação. Claramente há diferenças culturais quanto a essa distância física. Em algumas culturas nórdicas, por exemplo, prefere-se um espaço físico mais amplo que nas hispanoamericanas e árabes. $O$ valor desse critério para a análise contrastiva que será realizada nesta pesquisa se apoia no fato de que a distancia física entre os interlocutores é uma amostra icônica da diferença entre as culturas quanto aspectos de solidariedade e aproximação social entre os interlocutores.

Finalmente, os atos metapragmáticos revelam pressupostos sociais quanto à interação linguística. Certamente há diferenças interculturais, por exemplo, quanto à tolerância às interrupções, aos assaltos ao turno, às sobreposições, etc, levando em conta, ademais, as características das situações comunicativas comparadas.

Assim, no Capítulo III - Descrição a partir do sistema sociocultural, serão empregados esses critérios de análise, porém, os atos diretivos e assertivos terão maior foco, devido às características do corpus e a frequência de realizações. Esta análise será realizada com base também nas reflexões sobre os estudos antecedentes das estratégias de cortesia envolvidas no trabalho de face. 


\section{CORTESIA E PRINCÍPIOS PRAGMÁTICOS DE ATENUAÇÃO}

De acordo com a pesquisa de Lopes (2015), especialmente nas interações dos grupos de estudo, a atenuação além de relacionar-se com o trabalho da face em geral, pode contribuir para o alcance das metas consentidas na interação, constituindo-se, pois, um mecanismo retórico e estratégico. Em seu estudo, Lopes (2015) comprova como o recurso da atenuação contribui para a negociação, a progressão temática e para a busca do acordo nos procedimentos para alcançar uma tarefa comum em grupos de estudos universitários chilenos e brasileiros.

A tese de Lopes (2015) fundamenta-se em Briz (2013), artigo que define a atenuação pelo seu valor minimizador no marco da cortesia, de modo que, como mencionado anteriormente $o$ atenuador pode ser uma forma de expressão cortês, contudo, não é a única.

Além disso, o atenuador possui outros papéis pragmáticos submetidos a princípios da retórica da conversação. Em Briz (2013: 283) vemos que "a atenuação linguística se relaciona sempre com a eficácia e com a atividade argumentativa", possivelmente com a imagem social, mas nem sempre com a cortesia.

Fundamentada nos estudos pragmalinguísticos, grande interesse tem tido a atenuação na conversação coloquial do espanhol atual (Briz, 1997, 2002, 2001, 2003). Para a análise do corpus, é essencial considerar que o recurso da atenuação age no nível pragmático e semântico-pragmático.

Briz (2001: 146-163) esclarece que os atenuadores semânticopragmáticos, minimizam o conteúdo proposicional, em parte ou totalmente, mediante a modificação externa (pela ação de quantificadores, partículas discursivas, etc.) ou a seleção léxica (eufemismos, litotes, etc.). Os atenuadores semântico-pragmáticos escondem, retiram a nitidez e tornam imprecisos os limites dos conceitos.

A chamada atenuação semântica de toda a proposição, manifesta-se através de modificadores proposicionais, como os que agregam certos tipos de subordinadas a períodos concessivos, causais, adversativos, etc. (ex.: Sí, pero...). Essa alteração pode ocorrer por processos internos de modificação 
performativa, alterando o ato de enunciação; algo atenua não somente a quantidade de dinheiro como todo o ato de petição em "Dame algo de dinero". Os atenuadores de toda a proposição podem representar prelúdios mitigadores do desacordo.

Através da atenuação estritamente pragmática, pode ocorrer pela mitigação da força ilocutória de um ato de fala ou através da atenuação do papel dos participantes da enunciação.

A atenuação claramente pode manifestar-se como parte funcional do discurso argumentativo ou persuasivo, sobretudo em episódios de solicitações de opinião e debate, presentes em nosso material de análise, entre os informantes dos grupos de estudos gravados.

A atenuação na conversação é uma estratégia, isto é, mitigamos ou minoramos, desativamos ou deixamos de realizar um enunciado, muitas vezes, mais para alcançar a eficácia de um ato de fala que por cortesia; a cortesia pode tornar-se, em consequência, uma máscara que esconde esse propósito (Briz: 2001: 146).

Nesse sentido, a cortesia é um fenômeno estritamente social, enquanto que a atenuação é propriamente uma estratégia linguística, resultado dessa relação verbal e interpessoal, trata-se de um distanciamento da mensagem ou de seu fim, embora estejam implicados o falante e o ouvinte.

No exemplo de Briz (2013: 284):

(1) Juan no vendrá/ bueno/yo no es que lo sepa seguro

Vemos a atenuação funcionando como atividade argumentativa e estratégica, minimizando a força ilocutória e do papel do participante na enunciação. Já no exemplo seguinte, manifesta-se a cortesia:

(2) Siento darte la paliza a estas horas / pero es que necesito que me traigas los apuntes de lengua del martes

Vemos a atenuação como uma estratégia argumentativa através da qual a cortesia pode manifestar-se para conseguir o acordo. Reiteramos que constitui 
um "mecanismo retórico para convencer, conseguir um benefício, persuadir e, ao mesmo tempo, para cuidar das relações interpessoais" (Briz, 2013: 285).

Estrategicamente a atenuação é um mecanismo de distanciamento linguístico da mensagem e, ao mesmo tempo, de aproximação social, em razão de que o falante atenua a força ilocutória de seu enunciado a fim de aproximarse, social ou afetivamente, de seu interlocutor ou de terceiros, ou a fim de diminuir o afastamento (Briz, 2013: 286).

No presente estudo informaremos quando a atenuação se tratar de atividade de cortesia, como fenômeno dialogal e também quando se tratar de uma atividade de autoproteção. Interessa-nos verificar contrastivamente, em duas comunidades de fala, como está envolvido o trabalho da face entre as estratégias de atenuação.

Albelda Marco e Contreras (2009) realizaram um trabalho que demonstra que o tipo de análise que propusemos aqui é plausível. Os autores apresentaram uma análise contrastiva em dois corpora conversacionais em agências de viagens na Alemanha e na Espanha, a fim de demonstrar como a atenuação contribui para caracterizar de maneira diferente a imagem afiliação em duas culturas. Esse estudo apóia a conveniência de contar com o conceito de imagem básica, como o da imagem de afiliação que se preenche com os diferentes conteúdos segundo a cultura que é tratada.

Chegou-se às conclusões a partir dos resultados quantitativos de atenuação em cada falante, fundamentados em dois aspectos: a diferença de poder funcional e as diferentes funções da atenuação na construção da imagem de atenuação nas duas culturas.

Esse artigo adverte que as duas culturas analisadas apresentam uma clara diferença quanto ao poder funcional de cada interlocutor. Lembrando que a situação comunicativa de uma agência de viagens estampa um caráter assimétrico na relação entre os interlocutores, no corpus alemão, o cliente possui maior poder funcional que no espanhol. Observando os informantes alemães do material de análise, a maior porcentagem de atenuação no vendedor revela que o cliente possui maior poder funcional. Como exemplo, vêse que o vendedor alemão, propõe e oferece informação ou oferece opções do serviço oferecido, em muitos casos, pedindo permissão ao cliente. 
Em alguns tipos de atos de fala, o cliente espanhol é o que mais atenua em atos diretivos de perguntas e nos assertivos. Com relação aos atos assertivos, embora haja grande diferença entre clientes e vendedores espanhóis (42, $7 \%$ no cliente e $36 \%$ no vendedor), o contraste mais notório acontece com respeito ao cliente alemão ( $23,3 \%$ de atenuação). Outro fator que comprova a diferença quanto ao poder funcional é a presença comunicativa dos interlocutores: no corpus alemão o vendedor monopoliza mais as intervenções (78\%) e o cliente alemão somente intervém (22\%); enquanto que no espanhol o cliente espanhol intervém mais para fazer perguntas de informação, (41\%), porque o vendedor espanhol intervém menos (59\%).

Quanto às diferentes funções dos mecanismos de atenuação em ambas as culturas, no corpus espanhol, a atenuação funciona mais como mecanismo de negociação; no alemão, como procedimento para manter a distância social. Vê-se, pois, que clientes espanhóis atenuam pedidos de informação, e vendedores espanhóis atenuam atos diretivos de ordens e assertivos. Marcas como a presença de imperativos atenuados ou não por parte do vendedor, o excesso de justificações pelo cliente em atos assertivos e diretivos, a narração de experiências pessoais são amostras da necessidade de estabelecer-se uma imagem de confiança e solidariedade entre os interlocutores. No corpus alemão, a atenuação constrói uma imagem de afiliação baseada no respeito à privacidade do outro. Introduzem argumentos limitados ao nível profissional no lugar de temas pessoais, como no corpus espanhol, e atenuam mais diretivos de ordens que no material peninsular. Os resultados do artigo mencionado confirmam que o contaste entre culturas diferentes pode revelar que as imagens sociais podem ser preenchidas por diferentes aspectos e necessidades. Em nosso caso, buscaremos revelar quais aspectos e necessidades caracterizam as imagens dos estudantes da situação comunicativa em que se encontram. 


\section{CAPÍTULO II}

\section{PREMISSAS CULTURAIS E MANIFESTAÇÕES LINGUÍSTICAS: ASPECTOS METODOLÓGICOS PARA A ANÁLISE DA (DES)CORTESIA E DEMAIS PAPÉIS PRAGMÁTICOS ${ }^{13}$}

Este capítulo busca apresentar uma perspectiva metodológica para estudos de pragmática contrastiva. Lembrando que o objetivo geral deste trabalho é descrever, em cada comunidade de fala, as características da imagem social e dos valores culturais subjacentes ao comportamento cortês, à escolha de estratégias e dos modos de formulação de determinados atos de fala, levando em consideração, contudo, a diversidade das interações verbais.

O cerne da análise que é proposta aqui é a descrição da realidade social do usuário da língua, posto que o uso da linguagem se fundamenta no compartilhamento de parâmetros socioculturais. Assim, não nos ocupamos somente da observação de realizações comunicativas inseridas num corpus específico, mas, além disso, buscamos encontrar tendências de estilo de cortesia, que são estensíveis a outras situações de comunicação (Bravo, 2004a: 9). Contudo, até que ponto uma categorização será adequada para descrever a idiossincrasia de comportamentos de cortesia analisados em um corpus em particular? E em que medida se pode generalizar e teorizar comportamentos de (des)cortesia de um grupo de pessoas?

Embora as descrições dos componentes da imagem social básica possam ser identificáveis mediante as próprias experiências comunicativas do analista como falante nativo ou pelas experiências e impressões do mesmo em outra cultura, não cremos que dados nascidos da introspecção possam adquirir o valor de fiabilidade em um estudo científico. Não possuem validade científica uma vez que não se relacionam com fatos ou conceitos teóricos.

Além disso, certamente existe a possibilidade de encontrar em um corpus oral específico casos que coincidam com as descrições das premissas culturais formuladas nessa fase de introspecção, contudo dessa maneira não

\footnotetext{
13 Este capítulo fez parte de uma comunicação oral apresentada no II Workshop Internacional de Pragmática: a construção sócio-cognitiva da significação, realizado na cidade de Curitiba/PR, Brasil, entre os dias 26 a 28 de novembro de 2014.
} 
será sempre possível generalizar tais características a outras situações comunicativas.

Neste instante, fazemos alusão às três fases de análise propostas por Diana Bravo (2010), a saber: a introspecção, em que para a interpretação dos dados, o analista assume o papel de falante utilizando as suposições fundamentadas em sua própria experiência comunicativa como usuário da língua em estudo; a consulta, em que os informantes desempenham o papel de analistas e aplicam os mesmos métodos para interpretar as mesmas contribuições comunicativas antes analisadas, sem ter acesso às informações sobre os resultados obtidos pelos primeiros; e a exposição e fundamentação dos resultados, momento em que são explicitadas as premissas culturais que tiveram incidência na interpretação.

Cremos que se os conteúdos de imagem, que podemos associar às categorias de imagem social básica, são tomados pelo pesquisador como pressupostos para interpretar os comportamentos comunicativos observáveis em um corpus oral, constituem assim um instrumento de análise extraído das características de uma determinada comunidade de fala. Como tal, essas características socioculturais apresentarão maior validade científica se reduzirmos a ênfase nas percepções e pressupostos do analista, que não serão desprezados, mas sim comprovados a partir de dados fiáveis ou, antes, demonstrados empiricamente.

Cremos, pois, que o modelo de Bravo (2002b), que utiliza a introspecção como ferramenta, precisa ser associado a outras perspectivas para que detenha validade científica maior. Assim sendo, a fim de obter dados dos valores e comportamentos culturais para o estudo e interpretação da cortesia como fenômeno comunicativo, entendemos que o analista deve, de um lado, recorrer a estudos como os históricos, antropológicos, sociológicos, etc; de outro, pode empregar os chamados "testes de hábitos sociais" (Hernández-Flores (2002, 2003), Contreras (2004) e Bernal (2007)) ${ }^{14}$, para confirmar as impressões que obtiver a partir, da observação entre premissas culturais e o comportamento comunicativo dos falantes.

\footnotetext{
14 Os testes de hábitos sociais são uma ferramenta que consiste em colher dos informantes, que integram a comunidade de fala em estudo, comentários, impressões e pressupostos (meta)pragmáticos através de questionários. O uso destas ferramentas é uma proposta para apoiar a descrição das premissas do contexto sociocultural.
} 


\section{ASPECTOS METODOLÓGICOS DE PRAGMÁTICA CONTRASTIVA}

Entre os aspectos práticos, e com o fim de alcançar os objetivos propostos, esta metodologia contempla quatro etapas: 0 enfoque interdisciplinar, a análise do corpus oral, a aplicação de testes de hábitos sociais e o contraste cross-cultural.

Ese modelo é uma reformulação do que propôs Bravo (2002b). Em primeiro lugar, o enfoque interdisciplinar permite uma intersecção entre a Pragmática e outras disciplinas sociais, mediante a investigação bibliográfica de ciências que evidenciam o estudo de atitudes e comportamentos humanos na área da Pragmática, Sociologia, Antropologia, História, Psicologia, etc. $\mathrm{Na}$ área dos estudos pragmáticos em língua espanhola utilizaram esse tipo de material Fant (1989) e Bravo (1996).

Esta fase visa a aproximar-se das condições sociais que permitem que os falantes tenham acesso aos recursos da linguagem e possam controlá-los. Dessa maneira, descrever aspectos da idiossincrasia de uma comunidade de fala e, se possível, características da formação sociocultural e ideológica.

Nessa fase, encontraremos pistas para a descrição da realidade social do usuário da língua, posto que o uso da linguagem se situa em uma comunidade de fala cujos integrantes compartilham parâmetros culturais e inferências ancoradas em uma base sociocultural. Nessa busca bibliográfica, o alvo será a formulação das premissas culturais e de conteúdos específicos da imagem social básica, ou seja, nesta fase são estabelecidas deduções de constructos teóricos e hipóteses, que poderão ser comprovadas empiricamente na próxima fase, a análise do corpus oral, numa investigação sincrônica.

Posteriormente, na fase de análise do corpus oral, é possível examinar um corpus a fim de identificar aspectos linguísticos, comunicativos e conversacionais.Com critérios claros e definidos previamente, será possível selecionar determinados atos de fala, em que se manifestam estratégias pragmáticas, especialmente, as estratégias de cortesia empregadas na coconstrução das imagens dos interlocutores de uma interação verbal. São 
observados os atos de fala e as suas consequências imediatas, estendendo-se ao contexto de enunciação, ou seja, abrangendo tanto aspectos linguísticos como extralinguísticos. Assim é possível clarificar comportamentos comunicativos e explicar formulações linguísticas com base em fatores sociopragmáticos, situacionais, individuais e interacionais cujas pistas ou hipóteses foram levantadas na etapa anterior, como também o foram os conteúdos da imagem social básica.

Nesta fase, tanto quantitativa quanto qualitativamente, é possível inferir de um corpus, que deve ser representativo, os conhecimentos compartilhados pelos falantes e expor, portanto, como se relacionam as premissas culturais e os conteúdos específicos da imagem social básica em uma determinada comunidade de fala. O ponto de partida são os estudos sobre o comportamento humano e comunicativo e os estudos antecedentes sobre as estratégias de cortesia envolvidas na gestão de imagens, enfatizando as características discursivas, pragmáticas e semânticas das mesmas nos atos em que se inserem, como a diferença de poder funcional ou as diferentes funções da atenuação na construção da imagem (Haverkate, 2004).

Entretanto, para evitar o risco de obter como resultado formulações ad hoc, não generalizáveis a demais materiais de análise da mesma natureza, nem aplicáveis a outros propósitos científicos reiteramos que é fundamental que determinados tipos de atos de fala sejam selecionados e as ocorrências e aspectos relativos à frequência devem ser examinados de forma exaustiva no material de análise, segundo os objetivos da pesquisa.

$\mathrm{Na}$ terceira etapa, da aplicação de testes de hábitos sociais (Hernández Flores (2002), Contreras (2004) e Bernal (2007)) são formulados e aplicados questionários através dos quais os informantes tomam o papel de analistas e aplicam métodos definidos pelo pesquisador, cujas respostas podem apoiar as interpretações obtidas da análise do corpus, como também precisar, corroborar as características da imagem social e dos valores culturais subjacentes ao comportamento (des)cortês.

Para tanto, aplica-se a informantes, um questionário sobre 0 comportamento social. Insistimos que os materiais de análise - corpus oral e os testes de hábitos sociais - devem constituir amostras representativas segundo os objetivos do estudo. 
Assim, é possível evitar que o analista induza da primeira fase da pesquisa suposições e hipóteses que poderiam encontrar eco in situ, em um corpus específico e reduzido, o que o seria possível levá-lo a construir generalizações ilusoriamente empíricas.

Finalmente, na quarta etapa, e no caso das pesquisas comparativas, estabelece-se o contato cross-cultural e se contemplam e contrastam as variações linguísticas e socioculturais entre as comunidades de fala em estudo, assim se expõem e se fundamentam os resultados de forma contrastiva.

Não adotamos esta metodologia como uma ferramenta extremamente rígida, mas sim como um recurso que leva em consideração tanto a diversidade cultural e social quanto o estudo da própria situação comunicativa e seus recursos linguísticos. Dessa maneira, tanto o teste de hábitos sociais e a análise do corpus quanto o levantamento bibliográfico interdisciplinar nos levarão a reconhecer as premissas culturais subjacentes a como os informantes percebem e interpretam a cortesia.

Entre os aspectos teóricos, consideramos necessária a atualização e o exame do estado da questão, por isso apresentamos os antecedentes que possibilitaram definir o marco teórico que guia esta pesquisa. Lembramos também que na presente tese, a aproximação ao objeto de estudo é eminentemente qualitativo e de caráter exploratório. Nesse sentido, expusemos os passos relativos aos aspectos de índole teórica e prática. 


\section{APRESENTAÇÃO E DESCRIÇÃO DO CORPUS ORAL}

Quanto à seleção do material de análise, utilizamos aqui filmagens de alunos em grupos de estudo, de 18 a 30 anos, realizadas em duas universidades: no Chile, a Universidad de Santiago de Chile (USACH) e, no Brasil, a Universidade de São Paulo (USP). Embora as gravações tenham ocorrido em universidades circunscritas em países diferentes, foram consideradas disciplinas equivalentes nos diferentes cursos das áreas de Ciências Sociais e Humanas. O corpus total possui aproximadamente 25 horas de filmagens, realizadas entre os anos de 2009 e 2014.

Esse corpus foi construído com o apoio da Profa. Dra. Elisa Lopes, que desenvolveu a tese Análisis contrastivo de la atenuación en los grupos universitarios chilenos y brasileños: un estudio pragmalingüístico, na Pontificia Universidad Católica de Chile. Sua pesquisa discute como o recurso pragmático da atenuação se relaciona com a eficácia na comunicação e com a atividade argumentativa e compartilha com esta tese o mesmo corpus. Apesar disso, registramos aqui que a pesquisa de Lopes (2015) e esta possuem objetivos diferentes e, na fase de elaboração, ambas foram realizadas de maneira totalmente independente, sem nenhum tipo de interlocução.

Quanto às filmagens, não possuem a presença do documentador, ou seja, entrávamos em contato com os grupos de universitários que se reuniam, deixávamos a câmera com eles e voltávamos somente quando terminava o período de estudo em grupo. Os estudantes, que participam do grupo de estudos, sabiam que estavam sendo gravados, mas, em geral, interagiam com espontaneidade, com foco na meta a ser cumprida nesse encontro, principalmente após os primeiros minutos de filmagem.

Durante as gravações ambos os grupos de estudantes, tanto de brasileiros como de chilenos, tinham o objetivo de estudar para alguma atividade acadêmica que deveriam realizar, como uma prova, uma apresentação oral, um trabalho de pesquisa em grupo, entre outros. 
Quanto à origem e classe social dos informantes, os estudantes brasileiros e chilenos, em sua maioria pertencem à classe média e alta.

A transcrição do material seguiu os parâmetros dos sistemas de transcrição do grupo Val.Es.Co. (Briz e Grupo Valencia Español), que valoriza tanto o registro de elementos linguísticos quanto a descrição de aspectos extralinguísticos.

Este material de análise é composto por conversações coloquiais, com um tom informal, as quais apresentam escasso controle da produção das falas que não é planejada. Esses traços de coloquialidade são favorecidos também pela relação de igualdade social entre os interlocutores, certo grau de relação vivencial de proximidade (conhecimentos compartilhados) e um marco de interação familiar ( Briz, 2002b). Esse corpus possui o caráter dialogal (Briz, 2002b), com a característica da sucessão de intercâmbios; o caráter imediato, pois se desenvolve na coordenada temporal aqui-agora-diante de você; o caráter cooperativo, dado que ocorre com o outro e com a sua intervenção; e dinâmico, devido à alternância de turnos que não é determinada previamente.

Cada transcrição está acompanha de uma ficha técnica, adaptada de Briz (2002b: 36-37), representada a seguir:

a) Pesquisador:

b) Dados Identificadores da gravação:

- Data da gravação:

- Tempo da gravação:

- Lugar da gravação:

c) Situação comunicativa:

-Tema:

- Propósito ou teor funcional predominante: interpessoal

- Registro: informal

- Modo o canal: oral

d) Tipo de discurso:

e) Técnica de gravação:

- Conversação coloquial: gravação ordinária, observador não participante

f) Descrição dos participantes:

- Número de participantes:

- Ativos:

- Passivos: 
-Tipo de relação que os une: amizade, coleguismo.

-Sexo:

- Homens:

- Mulheres:

-Idade:

-Nível de estudos:

- médios:

- superiores:

-Profissões:

-Residência:

- Nível sociocultural:

- alto:

- médio:

- baixo:

A seguir, sistematizamos as filmagens e indicamos algumas características elementares.

Tabela 1 - Corpus - Santiago do Chile

\begin{tabular}{|c|c|c|c|c|}
\hline VIDEO & PARTICIPANTES & HOMENS & MULHERES & DURAÇÃO \\
\hline 1. V1 & 3 & 0 & 3 & $00: 45: 26$ \\
\hline 2. V2 & 4 & 0 & 4 & $00: 40: 31$ \\
\hline 3. V2.1 & 4 & 0 & 4 & $00: 51: 59$ \\
\hline 4. V3 & 3 & 1 & 2 & $01: 02: 13$ \\
\hline 5. V4 & 5 & 0 & 5 & $00: 39: 34$ \\
\hline 6. V5 & 5 & 1 & 4 & $01: 02: 36$ \\
\hline 7. V6 & 7 & 2 & 5 & $01: 02: 44$ \\
\hline 8. V7 & 3 & 1 & 2 & $01: 02: 38$ \\
\hline 9. V8 & 5 & 1 & 4 & $01: 02: 39$ \\
\hline 10. V9 & 4 & 1 & 3 & $01: 02: 31$ \\
\hline 11. V10 & 5 & 1 & 4 & $01: 02: 39$ \\
\hline 12. V11 & 3 & 1 & 2 & $01: 02: 40$ \\
\hline & & & & \\
\hline
\end{tabular}




\begin{tabular}{|c|c|c|c|c|}
\hline 13. V11.1 & 3 & 1 & 2 & $01: 02: 38$ \\
\hline 14. V12 & 2 & 0 & 2 & $00: 45: 00$ \\
\hline TOTAL & $\mathbf{5 6}$ & $\mathbf{1 0}$ & $\mathbf{4 6}$ & $\mathbf{1 3 : 0 5}$ \\
\hline
\end{tabular}

Tabela 2 - Corpus - São Paulo

\begin{tabular}{|l|c|c|c|c|}
\hline VIDEO & PARTICIPANTES & HOMENS & MULHERES & DURAÇÃO \\
\hline 1. BRAWP28/07/2009 & 2 & 1 & 1 & $00: 48: 00$ \\
\hline 2. BRAAS16/09/2009 & 2 & 0 & 2 & $00: 43: 15$ \\
\hline 3. BRAAS09/10/2009 & 2 & 0 & 2 & $00: 50: 00$ \\
\hline 4. BRACG03/12/2009 & 2 & 1 & 1 & $00: 36: 13$ \\
\hline 5. BRAFF03/12/2009 & 2 & 2 & 0 & $00: 49: 03$ \\
\hline 6. BRAAB03/12/2009 & 2 & 2 & 0 & $00: 48: 08$ \\
\hline 7. BRASL07/12/2009 & 2 & 0 & 2 & $00: 48: 27$ \\
\hline 8. BRAMV29/01/2009 & 2 & 1 & 1 & $00: 48: 15$ \\
\hline 9. BRAMR29/01/2010 & 2 & 0 & 2 & $00: 49: 03$ \\
\hline 10. BRAABCD20/01/2010 & 4 & 0 & 4 & $00: 47: 58$ \\
\hline 11. BRAABCD21/01/2010 & 4 & 0 & 4 & $00: 47: 15$ \\
\hline 12. BRAAB28/01/2014 & 2 & 0 & 2 & $00: 20: 00$ \\
\hline 13. BRAPAB29/01/2010 & 3 & 0 & 3 & $00: 48: 26$ \\
\hline 14. BRAABCDEFGH29/04/2014 & 9 & 4 & 5 & $00: 57: 00$ \\
\hline 15. BRAABCDEFGH26/05/2014 & 9 & 4 & 5 & $00: 50: 00$ \\
\hline 16. BRAAB03/07/2014 & 2 & 1 & 1 & $00: 45: 00$ \\
\hline TOTAL & $\mathbf{5 1}$ & $\mathbf{1 5}$ & $\mathbf{3 5}$ & $\mathbf{1 2 : 1 6}$ \\
\hline
\end{tabular}

A presença feminina supera a de homens, de maneira que $68,62 \%$ são mulheres no corpus em português e $82,14 \%$ são mulheres no corpus em espanhol.

No total das gravações, é necessário ressaltar também que o tipo de atividade que desempenham é crucial na determinação dos papeis dos falantes. Notamos que dos 14 eventos que compõem nosso material de análise chileno, 
na sua maioria, os estudantes implicados realizavam trabalhos de pesquisa. No material de análise em português, as atividades de prática universitária em grupo variam entre traduções, discussão de respostas de questionários, análise de textos literários, elaboração de apresentação oral etc. É necessário levar em consideração também que o tipo de atividade que desempenham os estudantes aumenta ou diminui o grau de preocupação com a ordem, uma vez que notamos que no Chile, é muito comum que os alunos elaborem juntos, como exigência das práticas universitárias, trabalhos de investigação científica, que exigem mais esforços relativos ao respeito à forma, à profundidade no tratamento dos temas, à escrita, à sistematização de ideias e de referenciais teóricos e demais práticas de pesquisa.

O fato de cada situação comunicativa gravada ser única reclama que a análise de corpus, num estudo como o nosso, não pode respaldar-se somente em si mesmo.

\section{APRESENTAÇÃO E DESCRIÇÃO DOS TESTES DE HÁBITOS SOCIAIS}

Quanto à aplicação dos testes de hábitos sociais, inicialmente, nossa intenção era obter cerca de cem testes respondidos em cada país, para reunir uma quantidade de amostras mais representativas no Brasil e no Chile. Conseguimos listas de e-mails de alunos das Faculdades de Letras da Universidade de São Paulo (USP) e da Pontificia Universidad Católica de Chile (PUC), de maneira que tentamos aplicar o teste on line mediante formulários criados na plataforma Google. Mas diante da quantidade modesta de devoluções, tivemos que desistir dessa tática e solicitar a professores que usassem parte de suas aulas para a aplicação de testes impressos, sob a supervisão deles, embora não pudessem explicar as instruções dos mesmos ou ajudar os alunos a responder as questões.

Essa estratégia limitou a nossa capacidade de captação de dados, uma vez que dependíamos da disponibilidade e aceitação dos professores, que tiveram que gastar em média quinze minutos de suas aulas para a aplicação de 
nossos questionários. Diante da dificuldade de alcançar a quantidade apropriada, solicitamos mais tarde a professores da Universidad de Santiago de Chile (USACH) também, do curso de tradução, que cooperassem com esta pesquisa.

No Brasil, devolveram-nos setenta testes respondidos, mas do Chile, somente nos chegaram, até o momento de iniciar a presente análise, quarenta testes, de maneira que decidimos separar aleatoriamente do total de testes brasileiros a mesma quantidade que tínhamos de testes chilenos, ou seja, quarenta.

O questionário distribuído no Chile foi elaborado usando "usted" como forma de tratamento, seguindo a tendência quanto ao tratamento utilizado no contexto acadêmico entre alunos, professores-pesquisadores nesse país, nessas situações o sujeito enunciador é marcado. No questionário veiculado no Brasil, utilizamos "você", cremos que há menos rigidez quanto a essa questão nesse contexto. Pressupomos que a forma de tratamento das instruções dos testes não influenciará substancialmente o grau de formalidade das respostas, uma vez que, por um lado, as questões sinalizam situações comunicativas específicas dentro do contexto acadêmico na qual o aluno deve imaginar-se. Mas, por outro lado, o fato de o questionário solicitar produções escritas, de ter sido respondido dentro dos espaços físicos de uma universidade e distribuído por um professor, associado ao fato de os alunos saberem que os interlocutores de suas respostas são analistas, pesquisadores da área de Letras, sim, pode influir nas respostas quanto à linguagem que empregam.

\subsection{Descrição dos dados sociológicos}

Quanto aos dados sociológicos, dos oitenta testes, temos: 
TABELA 3 - SÃO PAULO - TOTAL: 40 TESTES

DADOS SOCIOLÓGICOS

\begin{tabular}{|l|c|c|}
\hline \multicolumn{1}{|c|}{ FAIXA ETÁRIA } & QUANTIDADE & \% \\
\hline $17-25$ & 29 & 72,5 \\
\hline $26-55$ & 11 & 27,5 \\
\hline$>56$ & 0 & 0 \\
\hline
\end{tabular}

\begin{tabular}{|l|c|c|}
\hline \multicolumn{1}{|c|}{ SEXO } & QUANTIDADE & \% \\
\hline HOMENS & 16 & 40 \\
\hline MULHERES & 24 & 60 \\
\hline
\end{tabular}

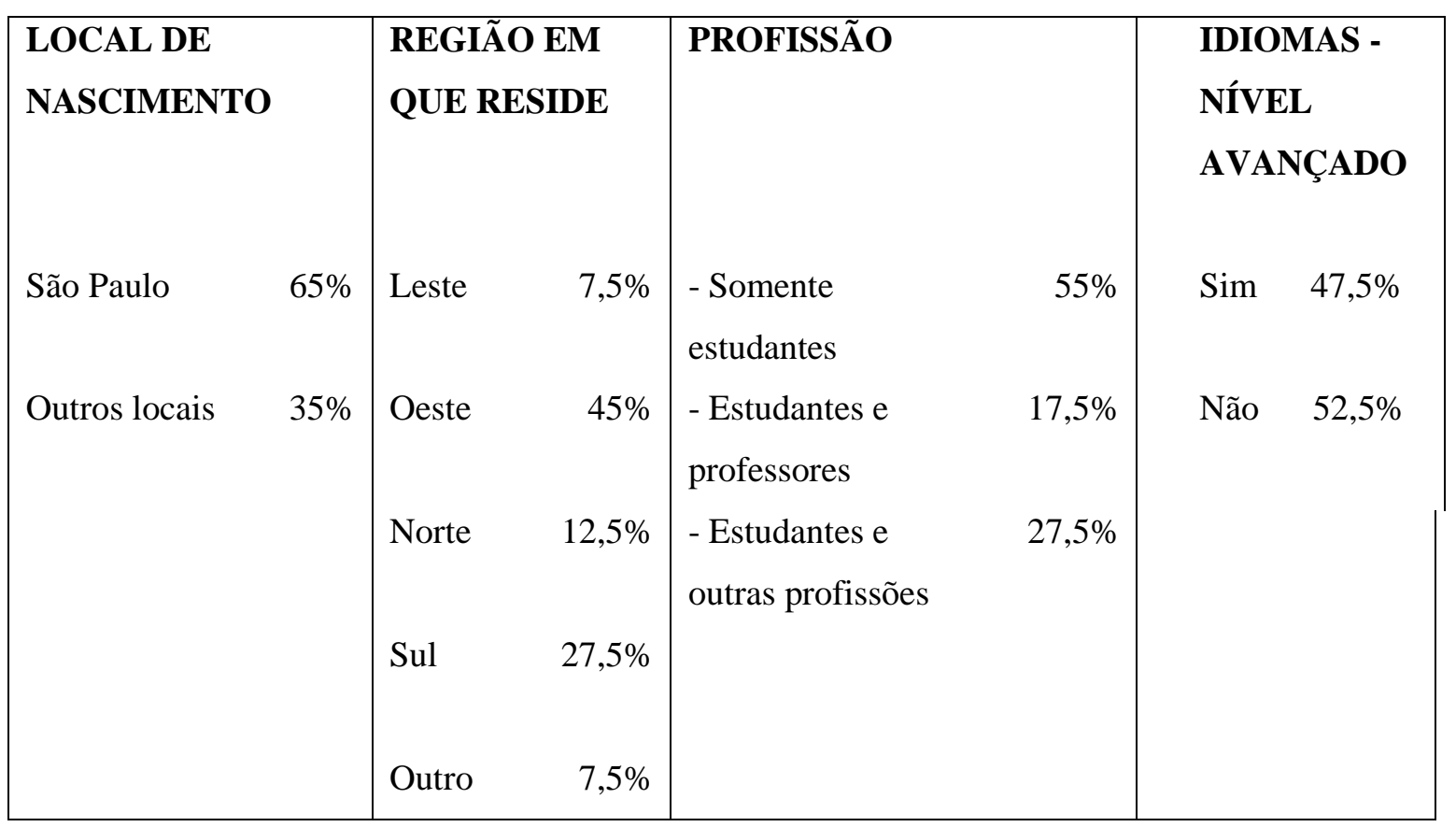

TABELA 4 - SANTIAGO DO CHILE - TOTAL: 40 TESTES

DADOS SOCIOLÓGICOS

\begin{tabular}{|l|c|c|}
\hline FAIXA ETÁRIA & QUANTIDADE & \% \\
\hline $17-25$ & 31 & 77,5 \\
\hline $26-55$ & 7 & 17,5 \\
\hline$>56$ & 2 & 5 \\
\hline
\end{tabular}

\begin{tabular}{|l|c|c|}
\hline SEXO & QUANTIDADE & $\boldsymbol{\%}$ \\
\hline HOMENS & 9 & 22,5 \\
\hline MULHERES & 31 & 77,5 \\
\hline
\end{tabular}




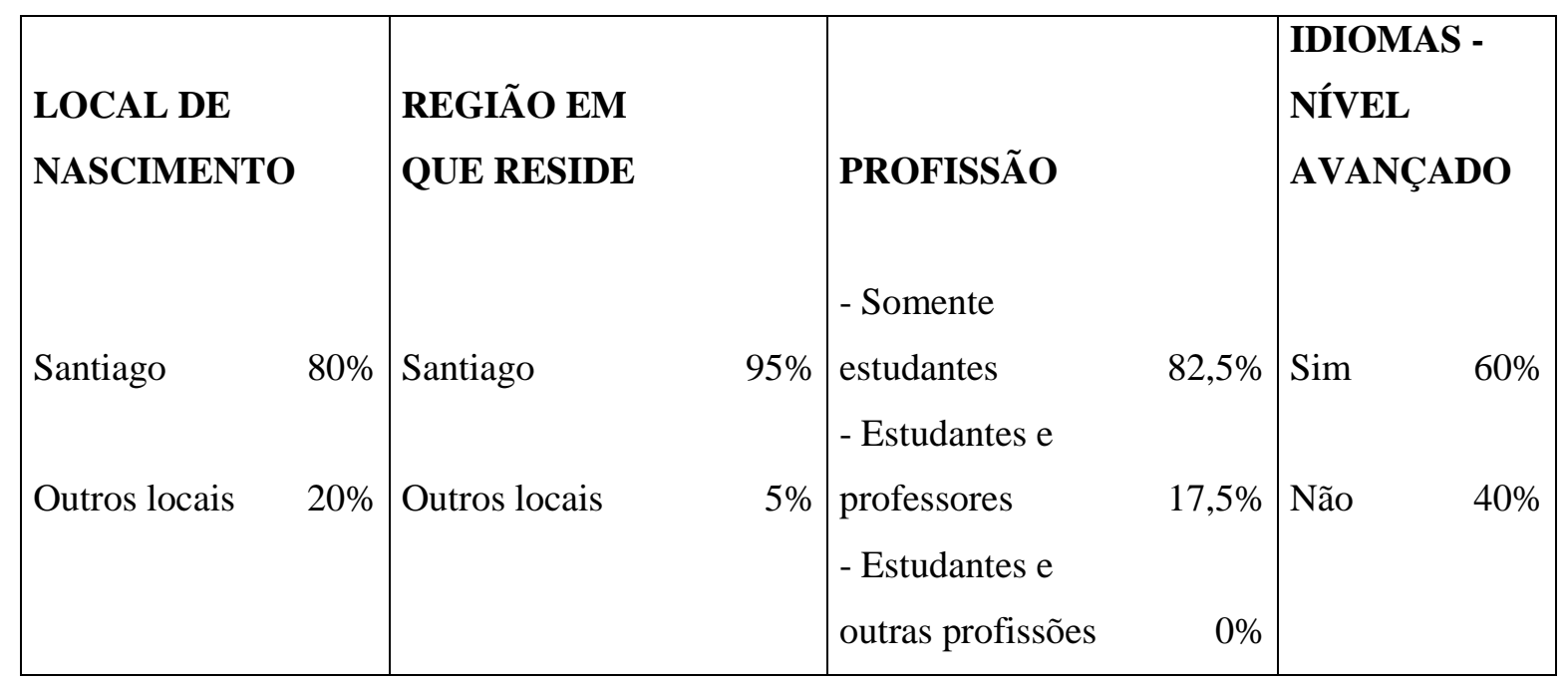

Os dados sociológicos são orientativos, uma vez que nosso interesse é que dentro de cada grupo haja características similares e entre informantes de São Paulo e Santiago encontremos características análogas e comparáveis. A proporção entre homens e mulheres não é igualitária, pois a maior parte está composta por mulheres, de igual modo como ocorreu entre os informantes do corpus (no corpus em português $68,62 \%$ são mulheres e no corpus em espanhol são $82,14 \%)$.

Embora reconheçamos que possa haver diferenças comportamentais e de estilo linguístico relativos aos gêneros, recordamos que os dados desses testes não serão avaliados isoladamente, mas sim através da comparação e das correspondências com os resultados da análise do corpus e das características do comportamento social compartilhado encontradas nas descrições dos estudos sociológios, antropológicos, históricos etc., que se verifica na primeira etapa deste estudo.

Todos os informantes são estudantes de cursos universitários de Ciências Humanas e a maioria deles, tanto no Brasil quanto no Chile, 72,5\% e $77,5 \%$, respectivamente, tem idades compreendidas entre os 17 e os 25 anos.

Dos informantes de São Paulo, todos residem nessa capital, e a maioria nasceu na metrópole. Entre os não nascidos na cidade de São Paulo, a maior parte nasceu no Estado de São Paulo e 4, em outros Estados brasileiros (Bahia, Maranhão, Ceará e Paraná). Todos os informantes são estudantes do curso de Letras da Universidade de São Paulo (USP) e 6 deles (15\%), além da faculdade 
de Letras, estão cursando ou já cursaram outro curso universitário (Sociologia, Filosofia, Arquitetura, Engenharia Mecânica, Jornalismo e História). Por aqueles que possuem conhecimentos em nível avançado de outros idiomas (47,5\%) foram citados o inglês e o espanhol.

Dos informantes chilenos, todos também moram na capital, Santiago do Chile, embora 3 tenham nascido fora da região metropolitana (Linares, Concepción e Viña del Mar). Todos são estudantes do curso de Letras da Pontificia Universidad Católica de Chile (PUC) ou do curso de Tradução da Universidad de Santiago de Chile (USACH). Entre todos, 3 (7,5\%), estão cursando também ou já cursaram outros cursos universitários (Sociologia, Relações Públicas e Secretariado). E 60\% possuem conhecimentos de nível avançado de outros idiomas; entre as línguas citadas temos português, italiano, alemão, francês e inglês. 


\section{CAPÍTULO III \\ DESCRIÇÃO A PARTIR DO SISTEMA SOCIOCULTURAL}

\section{O ENFOQUE INTERDISCIPLINAR}

\subsection{A cordialidade, a alegria e o jeitinho são brasileiros?}

Não é possível tratar da idiossincrasia do brasileiro sem mencionar o sociólogo Gilberto Freyre e sua obra Casa-grande \& Senzala (1933), muito comentado e discutido ensaio que revela aspectos da formação sociocultural brasileira. Com muita ênfase na questão da formação da sociedade, Freyre examinou a miscigenação que ocorreu, principalmente entre brancos, negros e índios.

De acordo com Freyre, as bases da sociedade brasileira muito se relacionavam com a estrutura da casa-grande, onde permaneciam família, bens e escravos; a casa-grande representou, portanto, um ícone do modelo social e político que se instaurou nesse gigante país.

A arquitetura, os móveis, a cadeira de balanço, a rede, a cozinha, as comidas de acre sabor africano, as crendices, os temores de Deus, as intimidades com os santos, o culto dos mortos, os hábitos de higiene, o banho de rio, a vida sexual, o "ranger da cama-de-vento", "a primeira sensação completa de homem", as superstições, os mal-assombrados, os enterros de anjo, as botijas de dobrões de ouro, os ex-votos, as procissões do Senhor-Morto, a música de percussão, os dengos, o bicho-papão, o desadoro do carnaval, a camaradagem fácil, a democracia social, a mistura de raças - tudo isso que nem era notado, pois não passava de maneiras triviais de nosso comportamento, de repente, desvelou o seu sentido profundo e adquiriu a saliência dos traços reveladores de nossa identidade. (Coutinho, 2005: 27)

Muitos elementos de outras culturas foram incorporados à identidade brasileira, desde aspectos de religiosidade a elementos físicos introduzidos na colônia, como a rede ou as comidas africanas citadas acima; mas no que se 
refere a comportamentos interpessoais, é notável nessa citação a associação que a obra de Freyre realiza entre o caráter da "camaradagem" proveniente desta rica mescla de povos.

De acordo com Freyre (1933: p.9), "quanto à miscibilidade, nenhum povo colonizador, dos modernos, excedeu ou sequer igualou nesse ponto aos portugueses". Nesse âmbito não cremos que o processo de miscigenação no Brasil tenha ocorrido de maneira natural e livre. Sabe-se que a mulher escrava, por exemplo, não detinha de dignidade social, principalmente no que se refere ao âmbito moral e sexual, de forma que uniões eram mantidas à força e violentamente, e filhos mestiços, frutos dessas relações, indubitavelmente sofriam a interiorização inerente à sociedade escravocrata.

Por ser o grupo mais numeroso e muito presente no processo de formação da sociedade brasileira, há que se considerar a relevância dos escravos negros ${ }^{15}$ na formação do ethos do brasileiro e na determinação do caráter nacional:

$\mathrm{Na}$ ternura, na mímica excessiva, no catolicismo em que se deliciam nossos sentidos, na música, no andar, na fala, no canto de ninar menino pequeno, em tudo o que é expressão sincera de vida, trazemos quase todos a marca da influência negra. (Freyre, 1933: 283)

Possivelmente essa "ternura" e "mímica excessiva" percebidos no modo de atuar do brasileiro eram constatadas por Freyre nas interações sociais do povo mestiço, como também na fala. No que diz ao uso da linguagem, não é possível afirmar, entretanto, que o comportamento linguístico do brasileiro

15 Vale ressaltar que as áreas de procedência dos escravos brasileiros são: Congo, Cabinda, Angola, Guiné, Cabo, Serra Leoa, Daomé, Sudão, Cacheo, Bissau, Camarões, Gabão, Costas do Grão, do Marfim, do Ouro, Reino da Ardia, Ilhas de Fernando Pó, Cabo verde, etc. (Coutinho, 2005: 149) 
sempre será como foi descrito por Freyre (1933), porque as escolhas lingüísticas e seu uso se submetem às características de cada situação comunicativa.

Ainda sublinhando a relação interpessoal, Coutinho (2005), que analisou a obra de Freyre, salienta os valores de humanização, igualdade e afetividade preconizadas pela presença do negro na sociedade brasileira.

Na verdade, o negro é que alforriou a alma brasileira, tornando-a mais humana e mais democrática, graças ao seu perfil afetivo e às riquezas culturais que nos ofereceu. Paradoxalmente, o escravo criou condições para que a democracia social germinasse nas terras americanas de língua portuguesa. (Coutinho, 2005: 112)

Embora Coutinho (2005) realce aqui mais a questão da democracia social que a presença das diferenças culturais estabelecidas na sociedade, as notáveis concepções de afetividade e ternura, mencionadas por Freyre, poderiam ser marcas, segundo o autor, da sociabilidade ímpar e do caráter "alegre, expansivo e sociável" que os negros (Freyre, 1933: 288) estampilhariam no comportamento comunicativo do brasileiro.

Contrastando-se o comportamento de populações negróides como a baiana - alegre, expansiva, sociável, loquaz - com outras menos influenciadas pelo sangue negro e mais pelo indígena - a piauiense, a paraibana ou mesmo a pernambucana - tem-se a impressão de povos diversos. Populações tristonhas, caladas, sonsas e até sorumbáticas, as do extremo Nordeste, principalmente nos sertões; sem a alegria comunicativa dos baianos; sem aquela petulância às vezes irritante. Mas também sem a sua graça, a sua espontaneidade, a sua cortesia, o seu riso bom e contagioso. $\mathrm{Na}$ Bahia tem-se a impressão de que todo dia é dia de festa. Desta de igreja brasileira com folha de canela, bolo, foguete, namoro. (Freyre, 1933: 288- 289)

Freyre (1933) associa à influência negra o comportamento com "graça", "espontaneidade", a "cortesia" e o "riso bom e contagioso" do brasileiro. Neste momento é necessário pontuar, no entanto, que não é possível afirmar que o povo brasileiro é sempre alegre, cortês, espontâneo e risonho. Sabe-se que, na verdade, as características arroladas por Freyre foram depreendidas por ele no 
início do século passado de maneira contrastiva, sem fundamentações científicas. Mas, apesar da distância temporal, a caracterização que o sociólogo apresenta encontra voz ainda na atualidade, principalmente quando estrangeiros, em contato com brasileiros, tentam descrever a nossa cultura e o modo como nos comportamos. Reiteramos, no entanto, que essas descrições muitas vezes supergeneralizam equivocadamente formas de comportamento.

Uma reportagem publicada pela BBC Brasil, em $2011^{16}$ indica que o povo brasileiro foi eleito o segundo povo mais "cool"17 do planeta, depois dos americanos, em uma lista elaborada pelo site de redes sociais Badoo. Conquanto tampouco esta pesquisa detenha rigor científico - cujos resultados possivelmente mais se relacionem com interesses da divulgação turística - essa enquete descreve o aspecto "festeiro" e, por conseguinte, "sociável" do comportamento do brasileiro, perspectiva também citada por Freyre no início século $X X$.

O Instituto Ethos ${ }^{18}$, uma organização não-governamental ${ }^{19}$, publicou uma pesquisa organizada pela empresa Marcondes Consultoria e a empresa britânica Barrett Values Centre sobre o retrato da percepção que os cidadãos brasileiros têm de si e da realidade que os cerca.

O levantamento de dados foi gerido pelo Instituto Datafolha, através de entrevistas com 2.544 pessoas de 160 municípios de todos os estados e Distrito Federal, em junho de 2010. Os informantes tiveram que responder a três perguntas:

Os entrevistados tiveram que escolher opções em três perguntas, entre elas, $20:$ 1) Quais valores são os mais representativos de quem você é? Os aspectos mais votados foram: amizade $(50,9 \%)$, família $(44 \%)$, honestidade

\footnotetext{
${ }^{16}$ Brasileiros são eleitos o segundo povo mais 'cool' do planeta. BBC Brasil, Brasília, 7 set. 2001. Acesso em: 15 mai. 2012. Disponível em:

http://www.bbc.co.uk/portuguese/noticias/2011/09/110907_brasil_cool_badoo_pesquisa_bg.shtml

${ }^{17}$ Este conceito em inglês se refere a pessoas ou coisas consideradas "legais", " modernas", "alguém que não se esforça para ser querido", ou algo ou alguém que pode ser descrito como agradável.

${ }^{18}$ Quais são os valores que os brasileiros mais prezam?, Instituto Ethos, São Paulo, 6 abr. 2011. Acesso em: 15 mai. 2012. Disponível em: http://institutoethos.blogspot.com.br/2011/04/quais-sao-os-valores-que-osbrasileiros.html

${ }^{19}$ Segundo o próprio Instituto Ethos, eles possuem a missão de mobilizar e sensibilizar empresas a gerir seus negócios de forma socialmente responsável.

${ }^{20}$ As demais perguntas são: 2) Quais são os mais representativos de como o Brasil opera hoje? Os aspectos mais escolhidos foram: corrupção $(54,1 \%)$; pobreza $(52,1 \%)$; crime/violência $(51,6 \%)$; desemprego (48,5\%); e analfabetismo (37,9\%); e 3) Quais valores deveriam ser representativos para o Brasil operar no futuro? Os aspectos mais votados foram: paz $(40,8 \%)$, justiça $(28,4 \%)$, redução da pobreza $(27,5 \%)$, moradia confortável $(26,6 \%)$ e cuidados com pessoas idosas $(26,4 \%)$.
} 
$(39,5 \%)$, respeito e humildade $(37,3 \%)$ e alegria $(34,7 \%)^{21}$. Segundo os comentários publicados pelo Instituto Ethos, os resultados revelam que "os brasileiros se vêem como pessoas que têm consideração pelos outros", valorizam o "contato próximo com as pessoas", "gostam de compartilhar alegria e confiança e possuem natureza alegre e modesta". A conclusão que o Instituto Ethos obtém é que a "imagem que o brasileiro faz de si é de um indivíduo gregário, amigável, honesto, alegre e humilde".

Conforme Freyre (1933), a "cortesia" do brasileiro, fruto da mestiçagem, também é singular. Certamente 0 autor se refere, de um modo geral em seu ensaio, à cortesia ritual e comportamental e não à cortesia linguística e estratégica, embora o autor forneça alguns exemplos de enunciados.

Temos no Brasil dois modos de colocar pronomes, enquanto o português só admite um - o modo "duro e imperativo": diga-me, faça-me, espere-me. Sem desprezarmos o modo português, criamos um novo, inteiramente nosso, caracteristicamente brasileiro: me diga, me faça, me espere. Modo bom, doce, de pedido. E servimo-nos dos dois. Ora, esses dois modos antagônicos de expressão, conforme necessidade de mando ou cerimônia, por um lado, e de intimidade ou de súplica, por outro, parecem-nos bem típicos das relações psicológicas que se desenvolveram através da nossa formação patriarcal entre senhores e escravos: entre as sinhá-moças e as mucamas; entre os brancos e os pretos. "Faça-me", é o senhor falando; o pai; o patriarca; "me dê", é o escravo, a mulher, o filho, a mucama. Parece-nos justo atribuir em grande parte aos escravos, aliados aos meninos, das casas-grandes, o modo brasileiro de colocar pronomes. Foi a maneira filial, e meio dengosa, que eles acharam de se dirigir ao pater famílias. Por outro lado o modo português adquiriu na boca dos senhores certo rango de ênfase hoje antipático: "faça-me isso"; "dê-me aquilo". (Freyre, 1933: 335)

O efeito "antipático" e "duro", aludido por Freyre, em enunciados como "faça-me isso" ou "dê-me aquilo" encontram raízes no âmbito histórico e social do Brasil, de marcada formação hierárquica e de desigual divisão de poderes.

No âmbito pragmático, a inferência que se obtém desses imperativos, na sociedade brasileira, também é fruto do fato de que os pedidos são os atos

\footnotetext{
${ }^{21}$ Entre recortes por poder aquisitivo, entre as menores faixas de renda e entre as mulheres de qualquer renda, a amizade e a família são os valores pessoais predominantes. Para os homens de maior renda, a competência é o aspecto mais valorizado. Entre os valores menos votados, encontram-se aqueles relacionados ao protagonismo e empreendedorismo individual, como resolução de conflitos, aceitação de riscos e inovação, abertura, diversidade e interdependência; segundo o Instituto Ethos, estes dados indicariam um indivíduo com dificuldades para negociações ou construções coletivas.
} 
exortativos que constituem a expressão dos atos de fala que ameaçam o direito do indivíduo de atuar autonomamente (Haverkate, 1994). Mediante seu objeto ilocutório, em um pedido, o falante expressa o fim de influir no comportamento intencional do ouvinte, de maneira que este realize a ação. "Faça-me isso" é, à vista disso, um exemplo de um ato verbal direto, impositivo, pelo qual o falante não mostra cortesia ou consideração pela imagem do ouvinte. Possivelmente esta não é a forma preferida pelos brasileiros no momento de expressar pedidos, entre interlocutores de igualitária divisão de poder social; cabe aqui uma análise de situações e contextos específicos, considerando o grau de imposição do ato e demais aspectos socioculturais.

Roberto DaMatta (1984), a partir do âmbito da Antropologia Social, busca proporcionar uma visão da sociedade brasileira e caracterizar os valores culturais do nosso povo, levando em consideração que, para ele, a palavra cultura representa "precisamente um estilo, um modo e um jeito (...) de fazer coisas" (1984: 17).

$\mathrm{Na}$ sociedade brasileira, as pessoas "seguem certos valores e julgam as ações humanas dentro de um padrão somente seu" (DaMatta, 1984: 12). Nesse ensaio, o autor afirma que se reconhece como brasileiro:

(...) porque sei que não existe jamais um "não" diante de situações formais e que todas admitem um "jeitinho" pela relação pessoal e pela amizade; porque entendo que ficar malandramente "em cima do muro" é algo honesto, necessário e prático no caso do meu sistema; (...) porque sou leal a meus amigos e nada posso negar a minha família; porque, finalmente, sei que tenho relações pessoais que não me deixam caminhar sozinho neste mundo, como fazem os meus amigos americanos, que se sempre se vêem e existem como indivíduos." (DaMatta, 1984: 16-17)

DaMatta (1984) caracteriza a identidade do brasileiro pela coletividade e humanização dos quais procedem valores como a amizade, a família, a sociabilidade e o respeito ao outro, enfim, aspectos muito presentes em outras caracterizações das mais variadas ciências que tentam examinar a cultura brasileira, como vimos aqui.

Nesse sentido, a sociedade brasileira, segundo DaMatta, devido à forma de atuar e os valores culturais que aponta, possui uma lógica por ele 
denominada "relacional", uma maneira de atuar que valoriza a conciliação e a negociação. Voltamos a frisar, porém, que embora possa fazer parte dos valores socioculturais do brasileiro a mencionada maneira de atuar, o comportamento linguístico se constrói em cada situação comunicativa específica, segundo as relações sociais que se estabelecem entre os falantes, o tema de um conversação, $o$ ato de fala que desenvolvem, entre outros fatores.

Sobre o famoso "jeitinho", a forma como contrariamos regras e leis, é um modo e um estilo de realizar. "É, sobretudo, um modo simpático, desesperado ou humano de relacionar o impessoal com o pessoal" (DaMatta, 1984: 99). O brasileiro prefere a familiaridade ao que é impessoal; e entre a opressão provinda de poucos que detêm o poder, entre o "pode" e o "não pode" o brasileiro busca encontrar um "jeito". Na verdade, muitas vezes não se busca, como poderia pensar-se, uma igualdade simpática ou uma relação contínua; na cultura brasileira, também há lugar para a ênfase da 'hierarquização inapelável com o famoso "sabe com quem está falando?".

Nessa sociedade desigual, o jeitinho brasileiro se instituiu como uma forma que as pessoas encontraram de relacionar-se, uma forma de convivência que concebeu uma área de confluência entre aquele que detém o poder e aquele não o detém.

Lívia Barbosa (1992) analisou esse "jeitinho brasileiro" como um instrumento para auxiliar o dia a dia, como uma estratégia nas relações de todas as classes sociais, na atualidade. É o elemento que intermedia o que é legal do ilegal, na procura por soluções entre o discurso oficial e a prática social.

O ensaio histórico Raízes do Brasil (1936), de Sérgio Buarque de Holanda, é outra obra que não pode deixar de ser citada aqui, por avaliar o processo de formação da sociedade brasileira, salientando o legado cultural da colonização brasileira e a dinâmica das adaptações que tais traços adquiriram no Brasil.

Como Freyre (1933), Buarque de Holanda (1936) relaciona o advento da democracia racial nesse país ao povoamento que se deu através dos mestiços, nos primeiros momentos oriundos de portugueses e índias, logo com escravas negras.

Famoso por propor a existência do caráter "cordial" dos brasileiros, o ensaio de Buarque de Holanda (1936) expõe que os brasileiros agiriam a partir 
da afetividade, encaram com dificuldade as formalizações políticas e têm preferência por unir o que é público ao privado.

A questão da cordialidade brasileira gerou intensos debates. Não cremos que o cidadão brasileiro constitui uma "raça" que unicamente busca sentimentos de concórdia; na verdade tomamos o conceito de cordialidade como um elemento de análise, um aspecto presente na sociedade brasileira que deve ser utilizado sem julgamentos éticos.

A cordialidade no Brasil se transformou numa conduta compartilhada entre os integrantes dessa cultura, como forma de comportamento, forma de atuar muitas vezes interpretada pelos estrangeiros como "alegria permanente".

Rodríguez (2000), no seu artigo sobre o ensino-aprendizagem de português a estrangeiros, faz referência acerca de se "a alegria é somente brasileira", possivelmente mencionando a imagem que os estrangeiros fazem da nossa cultura.

O autor, com foco na questão do ensino de língua portuguesa na Argentina, destaca que, para os argentinos, chama a atenção, por exemplo, o fato de os brasileiros utilizarem o primeiro nome como forma de identificação pessoal, ou seja, é pouco habitual o uso do sobrenome como forma de individualização, inclusive em situações públicas. De acordo com Rodríguez, essa característica é produto principalmente da falta de limites entre as esferas pública e privada da sociedade brasileira, e a origem do fenômeno certamente se encontra na evolução história e antropológica desse povo.

Comenta ainda que um aluno universitário no Brasil se dirige ao seu professor pelo primeiro nome, Professor Pedro, por exemplo, e essa ação não será considerada uma falta de respeito, sem importar a quantidade de títulos que este possua. De igual maneira, ocorre com o tratamento que oferecemos a personalidades públicas, como o presidente. Rodríguez (2000) chama a atenção para os jornais contemporâneos à publicação de seu artigo, que colocavam nos títulos de suas reportagens e nas notícias unicamente: presidente "Fernando Henrique". O que diria Rodríguez, ao ler, nos mesmos jornais, as notícias sobre o ex-presidente "Lula", pois o tratam pelo apelido e não pelo nome Luiz Inácio da 
Silva22? Claro está que falar de "presidente Silva" sim causaria muita estranheza em nosso país.

Outro ponto considerado por Rodríguez (2000) é o fato de que, segundo ele, no Brasil não é comum o contato efusivo para expressar-se em encontros e interações como o é na Argentina, quando, por exemplo, cumprimenta-se um amigo. Para Rodríguez, o afeto se expressa na verdade na forma de falar com o outro, sem que o contato físico seja fundamental.

Uma imagem que também se repete, quando se pensa em um brasileiro, de acordo com o autor, é a simpatia e o bom tratamento permanentes.

Todo extranjero queda encantado por la alegría de vivir y la constante felicidad que parece demostrar el pueblo brasileño ante la adversidad. Famosa y muy conveniente para resumir este concepto es la frase "a alegria é só brasileira" (La alegria es sólo brasileña). Subyace en ella el estereotipo básico que tiene el extranjero del país: un paraíso terrenal.

A conhecida "alegria brasileira" se trata de um estereótipo que, para Rodríguez, constitui na verdade um procedimento dinâmico capaz de manter a harmonia da organização social, através da interação interpessoal, para enfrentar a realidade dinâmica e conflitante da sociedade brasileira.

Outro conceito rememorado por Rodríguez é o do "jeitinho", associado na cultura argentina ao termo gauchada e avivada: gauchada se relaciona a ideia de favor, mas é um termo depreciativo; com esta, espera-se certa reciprocidade de quem recebe os benefícios dessa ação e, em geral, não se pede a estranhos; o termo avivada pressupõe sempre uma má intenção e o objetivo de tirar proveito do outro, prejudicando-o.

Para os estrangeiros, o jeitinho brasileiro, muito perceptível nas interações verbais, pode ser relacionado a uma aparente falsidade, segundo Rodríguez, isto é, as marcas de simpatia e interesse, podem interpretadas como hipocrisia.

Rodríguez destaca também o aspecto da negociação presente na cultura brasileira; com o "jeitinho", abre-se a possibilidade para alcançar o que se deseja

\footnotetext{
${ }^{22}$ Luiz Inácio da Silva agregou oficialmente o apelido "Lula" ao seu nome em 1982 - Luiz Inácio Lula da Silva.
} 
através de estratégias discursivas adequadas para obter-se o que se almeja do outro.

Dichas estrategias implican un conocimiento preciso de qué decir y cuándo hacerlo. Es lógico que para el nativo este comportamiento es natural, pero no lo es para el extranjero. Es aquí donde surge la idea de "seducción" que se siente al interactuar con un brasileño. Se reacciona sin considerar esta forma de "juego" y surgen los malos entendidos El jeitinho se trata de una negociación a la que el nativo está acostumbrado y puede llegar a producir impaciencia en quien no la comprende porque su éxito depende de una, a veces, demorada interacción linguística. Es en el terreno de las palabras en donde se establece el campo de acción del jeitinho. (Rodríguez, 2000)

As expressões discursivas que vamos analisar neste trabalho comprovarão se as premissas e valores culturais observados aqui regem a 0 comportamento comunicativo dos brasileiros que fazem parte das comunidades de fala em foco.

\subsection{Premissas culturais subjacentes às formações discursivas e ao comportamento comunicativo do brasileiro}

A fim de obter dados dos valores e comportamentos culturais para o estudo e interpretação da cortesia como fenômeno comunicativo, Andrade $(2010)^{23}$ verificou através de um teste de hábitos sociais que 100\% dos

\footnotetext{
${ }^{23}$ Um capítulo de Andrade (2010) se dedicou a observar a compreensão ou a impressão de predomínio enunciativo de rudeza por parte de brasileiros em contato com enunciados juvenis provenientes de uma variedade de língua de Santiago do Chile e outra de Madri, nos quais ocorriam os marcadores discursivos pues (ро), ya e claro, foco central do estudo. Responderam a um questionário, vinte e sete estudantes brasileiros, da oitava série de uma escola situada no Estado de São Paulo, com pelos menos quatro anos de estudos de língua espanhola. Após ouvir diálogos reais em espanhol extraídos do corpus e ter acesso às transcrições das mesmas, comentaram por escrito, de maneira espontânea, suas noções sobre o conceito de cortesia, suas impressões sobre as conversações com base nesse conceito. Entre as justificativas mais recorrentes e que revelaram quais são os principais sinais que guiam as inferências de suas interpretações quanto à presença ou ausência de cortesia, encontramos:

a) Extensão das intervenções: $7,40 \ldots \%$ dos estudantes deixaram transparecer que as respostas consideradas muito breves não são preferidas e não produzem uma implicatura de cortesia;

b) Truncamentos: $14,81 \ldots \%$ dos estudantes deixaram transparecer que os cortes bruscos de uma unidade discursiva realizada pelo próprio emissor são considerados sinais de descortesia;
} 
informantes consideram corteses as intervenções cujos efeitos reforçam a imagem do falante e apoiam a imagem do ouvinte.

O conteúdo das respostas de vinte e sete informantes brasileiros que tiveram contato com conversações gravadas de adolescentes chilenos e espanhóis resultaram em uma fonte de informação sobre o seu conhecimento social compartilhado, suas crenças, atitudes e valores próprios de seu grupo.

Os resultados dessa análise indicaram que grande parte dos informantes brasileiros concebe que uma atitude cortês, inserida nos contextos que thes foram apresentados, é aquela que busca salvaguardar a imagem do interlocutor com o fim de obter um grau de harmonia interpessoal adequado. Deduz-se das respostas dos estudantes brasileiros que um falante cortês deveria estar, portanto, preocupado em satisfazer os desejos da imagem de seu interlocutor, considerando-se a reciprocidade do tratamento. Essa concepção guiou a interpretação das manifestações comunicativas chilenas e espanholas por parte desses brasileiros.

Lima (2012) analisou a realização linguística dos pedidos de desculpas em situações espontâneas no português do Brasil e no espanhol da Argentina examinado fragmentos das atrações televisivas Big Brother Brasil e Gran Hermano Argentina, a partir de um ponto de vista pragmático.

Como resultados, no Brasil, Lima observou uma forte valorização da imagem pública frente aos telespectadores, e uma singular preocupação com a volta da interação, valorizando o consenso, através de posturas afiliativas. No corpus argentino, por sua vez, Lima comprovou que a intenção primeira é a valorização da imagem pessoal frente ao interlocutor direto, e a expressão da

c) Entonação: $37,03 \ldots \%$ dos estudantes deixaram transparecer que o tom de voz considerado por eles como "agressivo", "arrogante", "frio" ou "irônico" são sinais de descortesia;

d) Força ilocutória: $88,88 \ldots \%$ dos estudantes deixaram transparecer que associaram a várias intervenções certa força ou intenção que manifesta sentimentos ou atitudes do falante, como um modo de falar "agressivo", "frio" ou "cínico", entre os sinais de descortesia; em contrapartida, um falar "calmo" ou "tranquilo" são considerados sinais de cortesia;

e) Comportamento amigável: $100 \%$ dos estudantes deixaram transparecer que consideram corteses as intervenções cujos efeitos reforçam a imagem do emissor e apoiam a imagem do ouvinte, as quais podem minimizar a imposição, impedir conflitos sociais, considerar o ouvinte como uma pessoa honorável e estimável, buscar "aceitar e compreender" o interlocutor e buscar ser, ademais, "educado" e “simpático". 
própria opinião, mesmo em detrimento da manutenção da interação, pois o argentino não se esquiva do embate.

Novamente esses dados rememoram o conceito do "homem cordial", acunhado por Buarque de Holanda (1936) e à valorização da aparência de bondade e afetividade.

\subsection{Os componentes da imagem social brasileira}

Após ter repassado conceitos teóricos e coletado dados, a fim de obter uma descrição de fatores extralinguísticos, podemos identificar aspectos socioculturais específicos a brasileiros e conteúdos da imagem social. Lembramos que esses conteúdos não determinam comportamentos, mas sim nos dão pistas de valores sociais compartilhados, embora claramente não estejam presentes em todas as interações.

Diante do exposto, descrevemos aqui pressupostos, premissas e valores culturais notáveis nos contextos brasileiros, de maneira que, associada à imagem de afiliação, formulamos neste momento um conteúdo de imagem que se relaciona com a busca da eficácia na comunicação no Brasil: o componente de imagem de cordialidade. Notamos que um valor social brasileiro é mostrarse amigável, sociável e evidenciar respeito ao interlocutor. Esse conteúdo de imagem caracteriza a identidade do brasileiro pela coletividade e humanização e possui uma lógica relacional, uma maneira de atuar que valoriza a conciliação e a negociação (Freyre, 1933; Buarque de Holanda, 1936; DaMatta, 1984).

Igualmente, a imagem de cooperação (Fant e Granato, 2002) é reafirmada no trabalho de face nas interações brasileiras, possibilitando também a negociação. Esse componente de imagem revela o objetivo social de projetarse como um membro cooperativo; disposto a ajudar, respaldar os demais ou pelo menos renunciar a interferir.

A imagem de semelhança (Fant e Granato, 2002) também se mostra parte das premissas culturais do brasileiro pela necessidade de que o falante 
projete certo grau de semelhança com os outros membros da interação e, ao mesmo tempo, de que atribua o interlocutor semelhança com ele.

Ao analisar atos de fala específicos do corpus oral, poderemos examinar a atividade desses conhecimentos compartilhados pelos falantes.

\subsection{A ordem e o caos na sociedade chilena}

O período colonial no Chile foi longo e influenciador no que se refere à formação da cultura e da política chilena, uma vez que determinou os fundamentos ideológicos e sociais.

Após a conquista do reino do Chile por Pedro de Valdivia no século XVI, os mapuches ou araucanos, povo originário da região, caracterizado pelos espanhóis por habilidades de guerra, não aceitavam os ditames impostos pela coroa e se opunham com muita força à colonização, com guerra permanente. Essa situação de guerra complicava o estabelecimento de relações sociais equitativas e baseadas na confiança (Scheele, 2010: 15-16).

O espanhol que colonizou Chile, diferente do que colonizou outras regiões do continente, segundo Scheele (2010: 15-17), era de origem goda, homens aventureiros e militares oriundos do norte da península. De sua cultura militar depreenderam-se valores de disciplina, obediência e respeito às autoridades.

A forte institucionalidade e a ordem pública chilena também encontraram amparo na presença abundante de sacerdotes católicos durante o período colonial. Curiosamente no Chile, por influência do exército e da Igreja, as instituições estatais se estabeleceram antes que o resto da sociedade, que detinha um papel subordinado.

A independência, no início do século XIX, e o período até finais do mesmo século, abarcam outra época singular, com Diego Portales, influente primeiro ministro (1830-1837), que introduziu forte ideologia política e estabeleceu instituições estáveis para chegar-se a obter uma sociedade tranquila, enquanto no resto do continente se estabelecia no caos (Scheele, 2010: 14). Por outro lado, como as elites, o acreditava-se na passividade do povo como forma de 
determinar a nação, estabelecendo leis rígidas. O Chile teve, portanto, um modelo político hierárquico, um governo forte e centralizador, com algumas características de democracia.

O ideário de Portales, que se fundamentava em ordem política, estabilidade social e progresso econômico, mesmo com sua morte em 1937, predominou por todo o século XIX.

Para entender a cultura chilena é necessário apreender os traços da elite e dos grupos dominantes, embora não configurem a maioria. Tagle e Stuven (2014), em um estudo histórico, apresentam um dado alarmante: em 1870, somente $17,6 \%$ da população sabiam ler e escrever. Disso, podemos imaginar qual a quantidade de pessoas que fazia parte da classe dirigente na época.

Para a historiadora Ana María Stuven (1997), o conceito de "ordem" é, pois, um dos conceitos articuladores do consenso social da classe dirigente chilena durante o século XIX, a partir de sua independência, o que subjugou 0 desenvolvimento institucional e cultural do Chile durante a História.

O conceito de ordem vigente é a essência da cultura política da elite que procurou "modelar" a sociedade a partir dele. "El apego al valor "orden social" se relaciona con la concepción de poder que manejaba la clase dirigente y a través de la cual expresaba su visión jerárquica del mundo, que le concedía la hegemonía sobre el motor de cambio." (Stuven, 1997: 259).

A ordem é um conceito chave para compreender o universo de valores da cultura política em que se apoiou o grupo fundador do Estado para a construção do mesmo e para a elaboração dos elementos constitutivos da nação chilena. (Stuven, 1997: 262). A autora reitera ainda que os valores da sociedade dirigente da época tinham que conviver com o discurso ideológico liberal, espírito do século, que se atualizava no republicanismo, e os referentes sociais e culturais ancorados no conservadorismo.

O século XIX continha esta ambivalência: enquanto se buscavam as condições para realização da República, desejava-se frear a atualização das mudanças diante dos riscos que representava para a classe portadora da autoridade.

Es decir, el control del poder estatal reposaba sobre un cierto orden social jerarquizado, definido por el mismo grupo dirigente y reconocido por todo el 
cuerpo de la sociedad. De allí que la clase dirigente estuviera permanentemente atenta a la hegemonía de su ética y sus expresiones culturales. (Stuven, 1997: 266)

Essa noção de ordem interage com a presença da religião católica, a fim de frear o que é diferente das tradições, o que é novo e o que apregoa mudanças sociais.

Scheele (2010) se insere no debate sobre a cultura política chilena, quanto à inclinação atual do chileno para o conceito de ordem, que poderia ser explicado aludindo-se ao desenvolvimento histórico do país, mas, segundo ela, é mais provável que tal aspecto tenha nascido da aversão do povo chileno à agitação social, produto do abalo causado pelos períodos de Allende e Pinochet, que influenciaram e cravaram transformações nos valores chilenos (Scheele, 2010: 3).

A autora, de forma generalizada, afirma que o chileno é de caráter relativamente plácido e tem muito respeito às leis, normas e às autoridades. Segundo ela, após longos períodos de paz, somente na segunda metade do século XX, ocorreu uma ruptura radical na estabilidade política e social: primeiramente, a polarização política e pressão social, a partir dos anos sessenta culminou o que alguns classificam como turbulento governo de Salvador Allende e, em segundo lugar, as Forças Armadas empreenderam um golpe de Estado em 1973, acompanhado de muita violência, o que originou o regime autoritário de Augusto Pinochet, que perdurou por 17 anos.

Logo, do início do século XX até 1973, houve um período que modelava a cultura política, com a introdução de valores que complementaram crenças e premissas autoritárias que já existiam. Porém, a situação de experiência de uma situação de caos, crise econômica e agitação social puderam ocasionar o fortalecimento de atitudes e normas que privilegiavam a ordem; os cidadãos estavam, no governo de Pinochet, sujeitos à autoridade que inclusive fazia uso da força para manter a estabilidade social.

Outro aspecto relevante para a cultura chilena, segundo a historiadora Ana María Stuven (1997), é o papel da mulher que, no século XX, conseguiu emancipar-se da tutela masculina e integrar-se ao mundo público, buscando a crescente, embora incompleta, igualdade social. 
Em entrevista concedida à revista Paula (Mena, 2012), Stuven constata: "Somos um país de mujeres solas", que inclui indígenas, negras, mulatas, em menor número, todas defendendo os interesses de seus filhos e a liberdade de educá-los segundo os seus princípios e crenças. Assim, surgem as mulheres da elite "belicosas e voluntariosas", segundo a autora, que apoiam ativamente a Igreja.

Nas últimas décadas do século XIX, aproximadamente $40 \%$ dos lares chilenos eram chefiados por mulheres: solteiras que nunca se casaram, algumas com filhos (cerca de $30 \%$ entre 1850 e 1900), viúvas e uma grande quantidade de mulheres abandonadas por seus cônjuges, todas tiveram que conviver com a interiorização social e ao difícil acesso ao mercado laboral. Na atualidade, a situação gera debates, pois $55 \%$ das famílias que vivem em extrema pobreza são encabeçadas por mulheres.

A questão da desigualdade social chilena tem como protagonista a mulher, seja na esfera familiar ou no espaço público. Por isso não se pode falar de valores e conformação sociais sem citar a posição delas nessa sociedade. $O$ Chile possui uma estrutura de desigualdade associada às mulheres: "El hecho de que $40 \%$ de las mujeres sea jefa de hogar implica una discriminación de base, porque esas mujeres están solas. No es que el marido gane menos: el marido no existe", assevera Stuven em entrevista.

Nessa entrevista (Mena, 2012), Stuven destaca o conservadorismo da mulher chilena, que inclusive foi bastante relevante no Regime Militar de Augusto Pinochet:

(...) las mujeres fueron fundamentales en la campaña en contra de Allende. ¿Por qué? Porque es muy fácil gatillar en ellas un sentimiento conservador. Un gobierno que planteaba los peligros del comunismo explotó muy bien el temor de las mujeres que protegen a su prole. Me acuerdo de los discursos de la señora Lucía Hiriart ${ }^{24}$. Para una Navidad salió ella al lado de una estatua de Cupido hablando de que las mujeres estábamos destinadas al amor y a la casa. (Mena, 2012),

\footnotetext{
${ }^{24}$ Lucía Hiriart foi primeira-dama do Chile durante o regime de Augusto Pinochet
} 
O golpe militar do general Pinochet, fez surgir uma geração com outros valores, de controle, autoridade e busca por bens materiais. Não por acaso, nessa época que foram fundados colégios conservadores.

Ordem, aversão ao caos e conservadorismo parecem fazer parte dos valores e premissas culturais mais destacados na cultura chilena. Embora reconheçamos que a visão que se apresentou aqui não determina comportamentos de um modo geral, mas pode fazer parte de valores compartilhados. Cabe-nos analisar se as expressões de cortesia linguística integram tais crenças e visões de mundo.

\subsection{Premissas culturais subjacentes às formações discursivas e ao comportamento comunicativo do chileno}

Puga (2013a) angaria resultados de diversos estudos que realizou na área da atenuação linguística em corpora chilenos e testifica que os chilenos atenuam a linguagem através de expressões e construções linguísticas usadas com muita frequência. A atenuação no castelhano do Chile é realizada em maior grau e com singularidades com relação ao da Espanha, de maneira que, a partir dessa colocação, existe uma estreita relação entre a atenuação e a identidade chilena.

A atenuação é utilizada, entre outros casos, para referir-se a tabus e esquivar-se de conflitos; para cuidar da relação interpessoal e para manter as diferenças de classe e hierarquias sociais, através das proteções das faces dos interlocutores. Assim, em países onde a segregação social é mais nítida e presente, surgem, por conseguinte, maneiras de atenuar mais notórias e sofisticadas que em países mais igualitários (Puga, 2013a: 12).

Intensamente relacionado com eixos culturais, a atenuação ajuda a mascarar sentimentos, crenças, modos de ser ou a disposição para não cumprir normas pré-estabelecidas no Chile.

Nesse sentido, Puga (2013: 12) afirma que alguns traços da identidade chilena se relacionam à simulação, de modo que a atenuação na variedade linguística chilena facilitaria esse procedimento. 
A simulação se manifesta devido à valorização da ordem na sociedade chilena; se as normas vão contra aos interesses pessoais, podem ser acatadas formalmente, mas não são cumpridas. Explica Puga (2013: 12) que as origens dessa tendência podem ser históricas, se nos atentamos que a simulação era perpetrada até mesmo pelos colonizadores no momento de enfrentar-se com decretos de leis do rei da Espanha, distantes da realidade chilena e que iam de encontro aos interesses dos colonos.

Esto se expresa en la fórmula tradicional "se acata pero no se cumple" que, en relación con cualquier orden real, significaba que existía la intención recta de obedecerla pero la realidad imposibilitaba su implementación. Esto ocurría invariable e indefectiblemente con la legislación que protegía a los indios de los abusos de los conquistadores. (Puga, 2013a:12)

É interessante observar que não se questionavam as leis ou a sua validade, mas sim era demonstrado o respeito pela norma, pela ordem e pelas leis. Os princípios podem ser transgredidos desde que simultaneamente sejam reconhecidos; e se mantém assim uma aparência de respeito à ordem.

A tendência de mascarar a realidade, conforme Puga (2013 a: 14) continua presente na sociedade chilena e se manifesta de inúmeras maneiras como pelo legalismo excessivo, pela aderência formal e ritualista da ordem e pela paixão por "parecer bem" e "que a pobreza não seja notada". A tendência de ostentação da nobreza do século XIX se manifesta atualmente, por exemplo, pela importância desmedida que os chilenos outorgam à imagem pública, segundo Puga (2013a)

Vale dizer que não são todas as formas de simulação que se dão através da atenuação, mas esta ajuda os chilenos a esconder sentimentos, práticas e crenças não toleradas pela autoridade ou pela própria sociedade, de igual modo os ajuda a mascarar e disfarçar o que pragmaticamente se quer dizer.

A adequada utilização da atenuação é, portanto, aprendida e ensinada. As classes altas no Chile, fundamentalmente, são representativas no que se refere à atenuação. Dedicam-se, no seio familiar, a transmitir e supervisionar, através da repetição e proibições, condutas do que é socialmente aceito como cortês. Inclusive, nas classes altas, até mesmo a educação da cortesia se faz de 
maneira cortês; uma mãe pertencente à elite diria "querido, sería mejor que hicieras menos ruido" no lugar de "cállate".

\subsection{Os componentes da imagem social chilena}

O contexto social chileno manifesta um conteúdo de imagem que chamamos de imagem de ordem (Stuven, 1997), pela qual o indivíduo sente a necessidade de projetar uma valorização da ordem e respeito à mesma. Esse componente de imagem além de explicitar a concepção de poder social, o que facilita a presença de estratégias de atenuação linguística nas interações no Chile (Puga, 2013), também releva a necessidade de projetar respeito a essa hierarquia, ordem social ou à organização requerida pela própria situação comunicativa.

A imagem de hierarquia (Fant e Granato, 2002), portanto, também se focaliza entre as características das premissas culturais dessa comunidade de fala, porque se associa ao grau de poder, à influência e ao status de um indivíduo no contexto da interação. Assim, este sente a necessidade de mostrar que the corresponde certa posição hierárquica, o que, no caso de nossos informantes, universitários em grupos de estudos, pode revelar-se por aquele que demonstra deter mais conhecimentos quanto ao tema de que estão tratando na interação.

Ressaltamos que não cremos que os valores traçados aqui sejam frutos de um determinismo social, tanto no caso chileno como no caso brasileiro, que faça com que as interações verbais sejam consequência lógica de sua formação sócio-histórica. Identificamos, pois, conteúdos de imagem que, embora não sejam estáticos, fazem parte das premissas culturais e, portanto, podem ser aplicáveis a variadas situações comunicativas e trabalhar em conjunto com outros conteúdos de imagem que a situação comunicativa requeira. 


\section{ANÁLISE DO CORPUS ORAL25}

Após ter encontrado pistas para a descrição da realidade social dos usuários de cada comunidade de fala, analisamos nesta seção o corpus oral, os diálogos filmados e transcritos, investigando o fenômeno da cortesia e outras estratégias pragmáticas, com foco na dimensão sociopragmática, em comunidades de fala específicas, no Brasil e no Chile, de jovens universitários em grupos de estudos.

Buscamos identificar os aspectos linguísticos, comunicativos e conversacionais que possam corroborar a atividade dos componentes de imagem que identificamos entre as premissas culturais brasileira e chilena. No entanto, cabe ressaltar que executamos aqui uma análise descritiva dos fenômenos encontrados no corpus, o que não significa dizer que tais fenômenos possam ser generalizados necessariamente a outras situações comunicativas somente a partir da análise de um corpus particular. Tampouco, se um fenômeno foi encontrado somente no corpus chileno, por exemplo, não significa que não poderia ocorrer em algum contexto comunicativo do corpus brasileiro, mas sim esse fato nos dá pistas para que busquemos respostas à ausência ou presença de fenômenos através dos testes de hábitos sociais, que aplicamos, ou em estudos posteriores sobre o comportamento social e as formas linguísticas.

Especificamente, indagamo-nos, nesta etapa, quanto aos recursos utilizados na manifestação do trabalho de face realizado pelos participantes nas interações específicas nos grupos acadêmicos de estudo, em português e em espanhol, a fim de identificar características da co-construção de imagens nessas interações, em ambas as comunidades de fala e em determinados atos de fala, partindo do contexto específico em que ocorrem.

A análise que se executa na presente pesquisa observa a linguagem em um contexto de uso, conceito que inclui algumas características dos

\footnotetext{
25 Alguns resultados deste capítulo foram apresentados no II Congresso Internacional Interdisciplinar: (Des)cortesia - expressão de culturas?, que ocorreu na Universidade Cruzeiro do Sul, São Paulo, de 2 a 5 dedezembro de 2014, através da comunicação oral A linguagem reificadora de comportamentos sociais de cortesia: atos de fala entre universitários chilenos e brasileiros.
} 
participantes, a situação de fala, a análise das interações, as significações, os processos cognitivos, os aspectos culturais etc., como também elementos extralinguísticos ${ }^{26}$ relevantes para a interpretação dos aspectos linguísticos.

Os encontros orais com o fim de estudos, examinados aqui, constituem uma atividade não institucionalizada no âmbito acadêmico, embora os indivíduos envolvidos em um encontro destes realizem uma tarefa que atende às exigências do contexto universitário.

Trata-se de uma reunião presencial voluntária de estudantes movidos por objetivos comuns, como a elaboração ou desenvolvimento de diversas tarefas próprias do processo de formação universitária. Compõem-se, pois, por uma prática discursiva cujas interações desvendam o modo como os participantes constroem as suas próprias imagens e a de outros, com o objetivo de alcançar o consenso, muitas vezes, e, simultaneamente, apropriar-se do saber e coconstruir o conhecimento disciplinar (Harvey, 2006).

Identificamos no corpus a presença de diferentes episódios, dentro das conversações, e o desenvolvimento de variados temas e tópicos conversacionais. Vale ressaltar que neste estudo são analisados especialmente os atos de fala assertivos e diretivos, dois aspectos extraídos do modelo de análise contrastiva entre culturas apresentado por Haverkate (2004: 56-64). Particularmente, entre os atos assertivos, selecionamos para a análise os fenômenos que aparecem com maior frequência no corpus oral, destacando-se a repetição léxica - a autorrepetição e a heterorrepetição. A ironia, outro ato assertivo proposto por Haverkate (2004) como relevante em estudos contrastivos, será levada em conta também quando for significativa nas sequências examinadas segundo os objetivos deste estudo. De igual modo, selecionamos para a análise a petição, um ato diretivo, igualmente devido à frequência de ocorrências no corpus.

Com fundamentação em Linell (1998), na análise do corpus, atentamonos às relações que se estabelecem entre os estudantes dos grupos de estudos acadêmicos a partir do indivíduo que demonstra mais saberes e conhecimentos com relação ao tema central do encontro. A inspeção do corpus nos permite

\footnotetext{
${ }^{26}$ Quanto aos elementos extralingüísticos, são considerados como apoio para a interpretação e construção de significados das intervenções linguísticas analisadas nas filmagens do corpus e também são levados em consideração em eventuais comentários que são mencionados nas respostas aos testes de hábitos sociais.
} 
observar que, muitas vezes, os estudantes estabelecem relações assimétricas a partir da demonstração do conhecimento que detêm sobre a matéria de que tratam. No nível do discurso, examinamos no corpus a maneira como se posicionam os participantes que manifestam ter maior ou menor conhecimento do tema que discorrem.

Nesta fase, tanto quantitativa quanto qualitativamente, a partir das pistas dos conhecimentos compartilhados pelos falantes, buscamos, portanto, descrever os conteúdos específicos da imagem social básica em determinados eventos comunicativos.

\subsection{As estratégias de cortesia envolvidas na construção da imagem dos participantes da interação brasileira e chilena}

\subsubsection{Atos assertivos}

2.1.1.1. A repetição léxica

\subsection{Autorrepetição}

A co-construção do conhecimento em um grupo de estudos no âmbito acadêmico implica negociar, transmitir e compartilhar o saber, atividade que, no corpus que analisamos, estabelece os papéis hierárquicos entre os participantes; o aluno que demonstra mais conhecimento, em geral, assume o papel de "aluno-professor", como no fragmento (1), do corpus brasileiro:

(1)

G: (( )) ((se dá tempo) $)^{27} / / /$ ¡ai meu deus!// você já me falou dessa palavra TANTAS vezes// mas tantas vezes

C: (RISOS) ((lorsque))

G: ${ }^{28}$

G: eu perco as palavras// aaah/ olha o ((d'abord))

C: oh lá o ((d'abord))

${ }^{27}$ Olha na apostila, parece estar procurando algo referente à palavra que menciona.

${ }^{28}$ Continua procurando na apostila. 
G: eu perco as palavras ((isso que é o pior))/

C: mas então é [bom que a gente faça]

G: [¡nessa desorganização!]

C: exercício de leitura/ porque você vai se forçando a lembrar das palavras/

G: éhh

C: uma hora você/ vai precisar mesmo

(BraCG03/12/09)

Em (1) temos um exemplo que pertence à filmagem de dois estudantes, um jovem e uma jovem, que cursam juntos a habilitação de língua francesa, na Faculdade de Letras da USP, e, no momento da gravação, realizavam a tradução de um texto. Durante esta filmagem, de cerca de quarenta minutos, é a estudante $\mathrm{C}$ que detém a voz instrutiva, como é possível observar em "mas então é [bom que a gente faça] (...) exercício de leitura/ porque você vai se forçando a lembrar das palavras". Inclusive, a conduta do falante $G$ ressalta 0 papel que assume, como a exemplo do turno que contém autorrepetições da frase "tantas vezes" - "você já me falou dessa palavra TANTAS vezes// mas tantas vezes". Pudemos notar que, durante todo o evento comunicativo analisado, é ela, a falante $C$, que demonstra mais conhecimento linguístico em francês que seu colega, assim, domina mais o desenvolvimento dos tópicos conversacionais numa dinâmica que se consistiu em ler um texto em francês, traduzi-lo e comentar dúvidas.

No corpus brasileiro, em sua totalidade, vimos como a autorrepetição evidencia o envolvimento pessoal na atividade comunicativa, além de favorecer a construção da coerência textual.

Para esta análise, do total das filmagens e transcrições, selecionamos 263 sequências conversacionais em que a autorrepetição se manifestou em atos assertivos. Entre estas sequências, constatamos que na maioria delas, 246 (93,5\%), a autorrepetição esteve envolvida na expressão do grau de capacidade intelectual por um lado e no reforço da imagem de hierarquia e de excelência, por outro, em situações comunicativas nas quais ocorriam atos de correções ao interlocutor ou explanações sobre algum tópico conversacional. Vejamos um exemplo: 
G: eu mostrei/ minha obra-prima/ às grandes pes-/às pessoas grandes/

C: ahn ahn

G: e eu/ lhes/ deman/ lhes pedi§

C:

§perguntei/ ((aqui o caso é)) perguntei

G: ah é/ perguntei/ uhm // ((eu tava pensando se vinha uma opinião depois))

C: ahn

G: e eu lhes/ perguntei/ se meu desenho/ lhes fazia medo

C: é lhes dava medo/ ¿né? $/{ }^{\circ}((\text { em português ficaria melhor }))^{\circ}$

G: uhm/ a tradução em português ((varia mesmo))

(BraCG03/12/09)

Devemos levar em consideração que os atos assertivos, quando são empregados para tentar convencer 0 ouvinte sobre a verdade de sua proposição, são subclassificados como atos argumentativos. Nesse exemplo, notamos que a falante $C$ corrige de maneira direta a proposta de tradução oferecida pelo estudante $G$ mediante um assalto de turno e a repetição da opção lexical correta, segundo ela - "Sperguntei/ ((aqui o caso é)) perguntei". Esse comportamento se reproduz em seguida quando ela corrige novamente o seu colega em "é lhes dava medo/ ¿né?/ "(((em português ficaria melhor) )".

A autorrepetição, observamos, está associada à gestão da imagem que a falante $C$ tem de si mesma, sua imagem de excelência é salientada quando a interactante projeta suas atribuições dotadas de valor positivo nesta situação comunicativa. A imagem de hierarquia, por sua vez, também reforçada pela correção e autorrepetição, está associada aqui ao grau de poder, à influencia e ao status que a estudante $C$ adquire no contexto da interação.

Nas análises, é importante investigar quais são os fins dos interactantes ao utilizarem as suas ferramentas comunicativas e o que conseguem com elas (Fant e Granato, 2002), como também consideramos essencial tentar discernir os efeitos que tem $o$ ato de um interactante sobre o contexto em que se encontra.

Por essa perspectiva, para conseguir o acordo ou a aceitação do interlocutor, vemos que a falante $\mathrm{C}$, no exemplo (2), desempenha uma atividade social de atenuação de falante e ouvinte e, por conseguinte, manifesta cortesia quando, após corrigi-lo, diz: "em português ficaria melhor". O uso do tempo verbal futuro do pretérito expressa distância temporal com o presente do ato de fala da correção. Essa atenuação também manifesta cortesia a partir de uma estratégia evitativa que minimiza a asserção, atenuando sua força ilocutória. 
Para cuidar da relação interpessoal e social, vemos também valorizada aqui a imagem de cooperação, no trabalho de face nesta interação, possibilitando a negociação, embora não possamos comprovar que seja esta a interpretação de seu interlocutor. Revela-se o objetivo social de projetar-se como um membro cooperativo, pois a falante se mostra disposta a ajudar ou respaldar seu colega de estudos.

A atenuação é aqui um mecanismo estratégico e tático e, portanto, intencional que também foi encontrado em intervenções do falante $G$, quando após ter sua imagem de excelência ameaçada pelas correções de sua colega, produz movimentos de justificação no mesmo fragmento do corpus (2), como em "ah é/ perguntei/ uhm // ((eu tava pensando se vinha uma opinião depois))" e em "uhm/ a tradução em português ((varia mesmo))". Ambos são turnos que expressam o acordo com a falante $\mathrm{C}$, manifestando-se aqui a atenuação, como estratégia de autoproteção.

Nessas intervenções, podemos dizer inclusive que o marcador discursivo "ah él", na intervenção de G, que comumente poderia introduzir uma unidade discursiva que agrega uma ocorrência repentina, uma informação que o falante acaba de recordar, nesta situação comunicativa se associa à intenção do falante de evitar prejuízos à sua imagem de excelência, podendo possibilitar a interpretação de que em lugar de não saber ou conhecer a opção de tradução considerada correta, na verdade não se lembra.

Toda essa dinâmica como a correção da falante $C$ de enunciados do interlocutor $\mathrm{G}$, com fenômenos de autorrepetição, seguidos da atenuação do falante $G$ e atenuação de falante e de ouvinte por $C$, foi observada neste material de análise brasileiro, repetidas vezes como no próximo fragmento (3).

(3)

G: (( )) / quando// elee/ era rapaz/

$\mathrm{C}$ : menino menino

G: menino

C: menino

G: aaah é/ só ((garçon)) que é rapaz ¿¿¿né?? ((petit/petit garçon)) §

$\mathrm{C}$ :

menininho/

§é/((petit garçon)) é

(BraCG03/12/09) 
De 43 sequências em que se manifestou a autorrepetição selecionadas apenas nesta interação, BraCG03/12/09, em 18 delas (41,8\%) a autorrepetição esteve envolvida em atos de correção ao interlocutor ou transmissão de conhecimento, diante de algum equívoco que tenha cometido o estudante.

Em (3), temos uma correção referente ao domínio lexical do falante $G$, que ocupa, como vimos, uma posição de menor poder nesta interação. Contudo, no fragmento (4), é ele, o falante G, que corrige a C com "não/ oo narrador/ o narrador não é o príncipe"; ele provavelmente atenua o seu ato com a expressão de risos, após informar-Ihe que mais tarde ela vai perceber isso, durante o trabalho com o texto - "(RISOS) mais tarde". Possivelmente esta atitude paralinguística valoriza as imagens de afiliação, protege a imagem de autonomia de $\mathrm{C}$ e a imagem de cordialidade de $\mathrm{G}$.

(4)

C: (( o ((pequeno)) principe $))$

G: não/ oo narrador/ o narrador não é o príncipe

C: ¿o narrador não é o príncipe?

G: não/ você vai ver depois/ o narrador não é o príncipe/ é um aviador / você vai ver isso

C: ok

G: (RISOS) mais tarde

(BraCG03/12/09)

Levamos em consideração também que os indivíduos participantes de cada grupo de estudos possuem suas características individuais e cada situação comunicativa tem suas peculiares específicas, o que pode explicar o fato de que o encontro gravado do corpus em português, BraCG03/12/09, de onde retiramos os exemplos (1), (2), (3), (4) e (5) abarcou muitos dos casos de autorrepetições de todo o corpus brasileiro, e estas foram proferidas por quem demonstra maior conhecimento da matéria.

O fragmento (5), retirado do mesmo encontro de estudos, corrobora essas observações:

(5)

C: $[(($ era assim $))] / /$ pode/ pode falar era assim/ ((comment ça))/¿né?/ é/ é/ o assim mesmo/ (( você pode colocar isso aí mesmo porque por exemplo você fala) $) / \mathrm{AH} \uparrow /$ você vem e me pergunta/ i((comment tu fais?/ah/ como é que você faz/ ah/((comment ça $)) / \mathrm{ah} / \mathrm{assim} /$ ¿né? $\uparrow$

G: ((boceja)) 

G: EU// ¿mostrei? $\uparrow$
C: isso/mostrei $\downarrow$
G: eu mostrei/ minha obra-prima/ às grandes pes-/às pessoas grandes/
C: ahn ahn

Esse fragmento atesta que a falante $C$ detém a voz instrutiva e utiliza-se dos recursos do fenômeno da autorrepetição para formular os seus enunciados. Nesta sequência, a falante $C$ atenua a imposição de sua instrução com 0 modalizador "pode" - "//pode/ pode falar era assim/ ((comment ça))/¿né?/ é/ é/ o assim mesmo/ (( você pode colocar isso aí mesmo (...)", expressando uma estratégia de mitigação e reparação dos atos ameaçadores da imagem do outro e da própria, em outras palavras. Temos aqui a ocorrência de um ato diretivo, tipo de ato de fala que terá a sua própria seção mais adiante e veremos assim mais características relacionadas a suas realizações.

Em outro evento comunicativo, em que há duas participantes, alunas do curso de Letras da USP, que realizam juntas um trabalho de literatura, temos novamente a presença de risos após um ato de correção, na verdade, após a expressão de $\mathrm{B}$, mediante um assalto de turno, de insatisfação $-\S^{\circ}$ (maas) ${ }^{\circ}$.

(6)

A: é:// ${ }^{\circ}(\text { tá})^{\circ} / / /$ então/ no formato estrutural do conto/ os parágrafos extensos/ são/ a predominância/ são a pree§

B: $\quad \S^{\circ}\left(\right.$ maas) ${ }^{\circ}$

A: não/ no formato estrutural/do tempo// do conto/ HÁA predominância dos parágrafos extensoss

B: ée

A: preciso parafrasear/ ¿né?/

(RISOS)

(RUÍDOS)

A: (( )) há//há/háaa predomiNÂNcia/ só um óh// HÁ// existe predominância/

B: ée/ $\downarrow$ ((predominância))

(BRAMR29/01/2010)

Como um fenômeno autocêntrico e alocêntrico, os risos após um ato de correção podem constituir uma estratégia pragmática de atenuação da força ilocutoria do ato impositivo. Nesta sequência conversacional, parecem mitigar também a força do que é considerada uma inadequação no turno de A - "no formato estrutural do conto/ os parágrafos extensos/ são/ a predominância". 
Inclusive a falante $A$ intensifica a sua correção mediante uma repetição léxica introduzida por mais risos na intervenção "há//há/háaa/ predomiNÂNcia/ só um óh// HÁ// existe predominância", os quais parecem favorecer a afiliação.

Após o exame de todas as transcrições do corpus em português, encontramos 26 casos de correções, que ocorrem espontaneamente, após aquilo que um dos falantes considera um erro do interlocutor. Estes 26 casos ocorreram, portanto, sem a presença de marcadores de controle de contato ou atos preparatórios. Seis desses casos $(23 \%)$ apresentaram algum recurso de atenuação no turno do falante que corrige, como o uso de verbos perfomativos (eu acho que...) ou risos. Vamos ver mais alguns exemplos.

Em (7), temos outro evento que conta com dois estudantes, ambos do sexo masculino, que se preparam juntos para uma prova de Estudos Clássicos II, disciplina de literatura da Faculdade de Letras da USP, e desempenham uma dinâmica que consiste em ler perguntas previamente impressas, debater possíveis soluções, consultar livros e cadernos e redigir as respostas após a discussão. Em toda a filmagem e transcrição, notamos que o falante $A$ utiliza frequentemente marcadores de contato que buscam o apoio discursivo; o falante B, por sua vez, não possui uma dicção muito clara e, em relação ao falante $A$, domina pouquíssimos turnos e suas intervenções são, em geral, curtas.

(7)

A: são expectadores pode-se dizer

B: espectadores

A: é $\downarrow /$ porque vai depender/ você pode escrever até ¿né? $\uparrow$ de acordo com o evento/ os espectadores vão ser de um tipo/por exemplo no::/ sei lá/eeeh/ panegírico// (vo)cê vai ter um tipo de espectador// um tipo de espectadores/ se for uuum dis/ uum/ uma homenagem fun-um discurso fúnebre ¿que se fala? $\uparrow / /$ uma oração fúnebre/ vai ser outra coisa/ e assim por diante/ aí você/ ponto final $\downarrow /$ aí no próximo parágrafo/ você coloca assim $\downarrow /$ Aristóteles/ ainda// eeeh/ ainda fez uma classificação de acordo/ com/ com o que ele precisava no discurso/ cada um desses três gêneros / ¿não é isso?^

B: éee

(BraFAFB03/12/2009)

Como se pode observar, o falante A detém a voz instrutiva, constrói verbalmente uma das respostas requeridas, enquanto seu colega $B$ registra 0 que diz por escrito. O fenômeno da autorrepetição, que é frequente nos turnos de $A$ em toda a filmagem, neste caso, auxilia o processo formulativo na 
apresentação de uma ideia - "os espectadores vão ser de um tipo/por exemplo nooo/ sei lá/eeeh/ panegírico// (vo)cê vai ter um tipo de espectador// um tipo de espectadores/".

Embora o falante $\mathrm{A}$ demonstre mais conhecimento com relação à matéria, utiliza-se de mecanismos atenuadores como em: "são expectadores pode-se dizer"; "uma homenagem fun-um discurso fúnebre ¿que se fala?// uma oração fúnebre"; "cada um desses três gêneros / ¿não é isso?". As expressões destacadas figuram estruturas que indicam hesitação, minoram a imposição e a força ilocutória da asserção e sugerem a abertura e o intercâmbio de ideias e opiniões, lembrando que tais atividades afirmativas da imagem do interlocutor promovem a própria imagem do falante também na cultura brasileira e valoriza a sua imagem de cordialidade. $O$ falante $A$, conjuntamente, reforça a imagem de semelhança e de cooperação de $B$, atribuindo este semelhança com ele, podendo fazer-lhe sentir que coopera.

Marcadores de controle de contato como "não é isso?" chamam a atenção do ouvinte B, solicitando uma confirmação do que foi dito antes, supondo-se, assim, uma mudança de turno. Entretanto, como essa mudança não se completa, possivelmente esses marcadores de contato, empregados por A, desempenham a função de chamar a atenção do ouvinte sobre a informação comunicada previamente para apresentá-la como se fosse compartilhada por este. Assim, o falante A busca conseguir que $B$ se una a sua opinião. Pode reforçar, dessa maneira, a imagem de cooperação, embora esse operador pragmático de contato, por seu valor exortativo, possa manifestar também certo valor argumentativo, sinal do apelo do falante para que o ouvinte adote a sua linha de pensamento.

O marcador formulativo "sei lá", em "por exemplo nooo/ sei láleeeh/ panegírico", desempenha a função de estruturar o discurso, permitindo que o falante A organize o seu pensamento antes de produzir o enunciado. "Sei lá" pode revelar as dúvidas e os retrocessos no processo de produção da mensagem, certa hesitação ou indecisão, preenchendo a pausa de planejamento verbal. Ainda que não esteja diretamente ligado às estratégias de cortesia sempre, nesse contexto, este marcador atenua o falante e o ouvinte, pois uma possível incerteza de $A$, indiretamente, evita a imposição de sua asseveração. 
Em (8), temos um fragmento que faz parte da mesma interação:

(8)

A: a quarta é fácil oh ${ }^{29}$ ¿beleza?^

B: beleza $\downarrow$

A: quais são as formas ((artísticas))?

B: ahn

A: ¿((quais são as formas artísticas e inartísticas))?

B: aaahn as artísticas são (( )) ou seja dizer assim que§

A:

pela arte ¿e o que é retórica? $\uparrow$ a arte do bem dizer§

B:

$\S a h$ é/ desculpa $\downarrow$ inartísticas/

inartísticas são aquelas que (( )) são aquelas em que/ aaahn ((claro que se)) aahn/ oo ((

)) ele era grego nasceu na Grécia ele era poeta isso num isso num $(())$ agora ((se eu disser

)) por exemplo o quanto ele era:// o quanto a sua poesia§

(BraFAFB03/12/2009)

O falante $A$ também domina o desenvolvimento do tópico conversacional e busca controlar o contato com o interlocutor com um marcador discursivo apelativo - "a quarta é fácil oh ¿beleza?" -, e com uma pergunta retórica para reforçar ou reafirmar seu próprio ponto de vista - "não o contrário/ artísticas são feitas pela arte ¿e o que é retórica? $\uparrow$ a arte do bem dizer".

Chama-nos a atenção o fato de o falante $B$ desculpar-se por demonstrar não saber a resposta de uma questão, em "§ah é/ desculpa $\downarrow$ inartísticas/ inartísticas são aquelas que (...)". Como já tínhamos observado nos exemplos (2) e (3), o marcador "ah é" introduz, neste contexto, a unidade do discurso após a correção do interlocutor, numa estratégia afirmativa de evitar prejuízos à sua imagem de excelência, sua necessidade de sobressair ou de, ao menos, mostrar-se em posse de qualidades julgadas como positivas.

O pedido de desculpas, por sua vez, pode evidenciar um aspecto das premissas culturais desses falantes, o fato de não expressar conhecimento quanto à matéria em estudo, nesse evento comunicativo, fere sua imagem de semelhança com os outros membros, uma vez que, se isso não ocorre, há a ameaça de exclusão. Ao mesmo tempo, não demonstrar conhecimento ameaça sua imagem de cooperação com base em que um objetivo social primordial em um evento como o encontro para o estudo é mostrar-se como membro cooperativo neste processo de ensino-aprendizagem.

\footnotetext{
${ }^{29}$ Olha para a pergunta.
} 
Aqui apresentamos mais um exemplo desta situação:

(9)

G: elas não $\downarrow / /$ eles

C: $\left[{ }^{\circ}((\text { são as pressas }))^{\circ}\right]$

G: [eles/ é elas]

G: não $\downarrow$

C: não?^

G: são [as cobras]

C: $\quad$ [ah/são as cobras $] /$ perdão

(BRACG03/12/2009)

Nessa amostra, de cujo encontro de estudos já analisamos alguns fragmentos, temos uma jovem, a falante $C$, que detêm a voz instrutiva, numa atividade de tradução de um texto em francês. Contudo, nessa sequência, é seu colega, o falante $G$, quem a corrige diretamente, como também já vimos acontecer nesta interação - "elas não ل// eles" - e ela pede perdão - "[ah/ são as cobras] / perdão" -, protegendo a sua imagem. Notamos que o pedido de desculpas, um ato expressivo e reativo, favorece a empatia e também a expressão ou implicação de que o falante deixou de agir conforme às normas vigentes na comunidade de que faz parte (Goffman, 1979, Haverkate, 1994: 97).

No próximo exemplo, encontramos uma marcada referência às premissas culturais, um dado metapragmático que se destacou na sequência conversacional a seguir, (10):

(10)

B: mas a// que nem-que nem// eu acho que/ por outro lado/ por uma parte é bom/ aquilo que você falou deee// às vezes uma pessoa/ faz uma beste:ira/ de ficá(r)/ porque aqui a gente não ve isso/ ¿né? $\uparrow /$ acho que isso/ é uma coisa boa

A: éee/ todo muito tá se protegendo/ ¿né? $\uparrow /$ no-na

B: uhum

A: é uma ((missão))/ meu mito// ninguém sabe (( )) onde eu nasci/ onde/ nada/

B: eu digo assim/ eu acho que/ mesmo quando você se expõe/ as outras pessoas/ no geral/ acabam respeitandoo/

A: é-é// eu não sei por que tem esse medo/ por que aqui todo mundo é muito respeitoso/ se fosse na minha faculdade/ na minha faculdaade/ ai gente/ era uma fa- uma ((farra))/ se você falasse qualquer besteira/ pelo amor de deus/ e aqui não// é legal/ eu acho o pessoal super respeitoso/

B: é verdade

(BraMR29/01/2010) 
Nesse evento, temos duas participantes, alunas do curso de Letras da USP, que estudam literatura juntas e comentam suas crenças quanto a pressupostos sociais subjacentes à interação - "se você falasse qualquer besteira/ pelo amor de deus/ e aqui não// é legal/ eu acho o pessoal super respeitoso/". Conforme Lopes e Andrade (2012), nesta comunidade de fala brasileira são considerados corteses e valorizados socialmente comportamentos cujos efeitos apóiam a imagem do ouvinte, que revelam "respeito", "simpatia" e "gentileza". Assim, nesse ato metapragmático, se evidencia o valor social relativo à imagem de cordialidade, que se remete a mostrar-se amigável, sociável e evidenciar respeito ao interlocutor.

De um modo geral, notamos que, no corpus em português, a autorrepetição mostrou-se participante de processos formulativos, como também se observa em (10) em "/ se fosse na minha faculdade/ na minha faculda:de/ ai gente/ era uma fa- uma ((farra))l", para produzir uma linguagem mais eficiente, preencher pausas ou precisar ideias com menor esforço. Como estratégia pragmática, o falante que se autorrepete muitas vezes busca facilitar a compreensão por parte de seu(s) ouvintes(s), enquanto reformula seu enunciado.

Na gestão interrelacional, na maioria dos casos analisados no corpus em português são distinguidas estratégias afirmativas das imagens de hierarquia e excelência, como já havíamos mencionado, e ressaltamos que, muitas vezes, manifestam-se juntamente nestas sequências a valorização das imagens de cordialidade, semelhança e cooperação. Nesse sentido, nas conversações do corpus de São Paulo, as sequências em que ocorrem autorrepetições selecionadas, muitas manifestam estratégias de atenuação, muitas delas envolvidas com a cortesia.

O exemplo (11) é um modelo dessas considerações. A falante $A$, que durante todo o evento comunicativo figurou como "aluna-professora", expressa a repetição no processo de formulação de sua asserção - "é:: /ahn::/o gênero é:: / o gênero do-do-do texto/ é o con:to/que.".

A: aqui

B: ¿não ée?^

A: é $\downarrow$ 
B: ((acho que cabe))

A: então//mas aí tem que começá(r)//éee /aaahn/o gênero éee / o gênero do-do-do texto/ é o conto/queee/ e conto tenta/tenta captar e retratar uma vida na sua integridade de forma suscinta// (( ))/éee /o personageeem/ o momento em especial promoção

B: ¿você quer colocar isso aqui/ dePOis ou antes?

A: acho que tem que ser antes/ ¿né?^/ porque nós vamos tratar de/gênero

B: tá/ então deixa eu copiar aqui/ ¿né?^

(BraMR29/01/2010)

Nessa interação, essas duas estudantes de literatura da USP produzem intervenções de forma quase equilibrada, porém, vemos claramente papéis estabelecidos em quase todo o tempo de filmagem: a falante $A$ propõe temas conversacionais, lê trechos de textos, enquanto $B$ anota as conclusões dos debates que se levantam. Dessa forma, a aluna A detém, de certa maneira, a voz instrutiva, mas constantemente atenua as suas asserções - "então//mas aí tem que começá(r)//éee /aaahn/"; "acho que tem que ser antes/ ¿né??".

A impersonalização "tem que começá(r)" é uma tática de distanciamento da mensagem, assim, a falante $A$ evita as responsabilidade sobre o que diz e também minora a força de um ato exortativo. Outra tática de atenuação, "acho que", mitiga a força da certeza do enunciado ou do grau do conhecimento da falante $A$, o que valoriza a imagem de semelhança de sua ouvinte e, ao mesmo, torna-se um escudo protetor de sua imagem de cordialidade, se consideramos que mostrar-se pouco impositivo é um valor social nessa comunidade de fala.

O próximo evento brasileiro que nos chamou a atenção, do qual selecionamos alguns fragmentos, conta com duas participantes, ambas do segundo semestre do curso de Letras da USP, que elaboram juntas o trabalho final da disciplina de Introdução aos Estudos Literários II. A dinâmica que observamos neste encontro de estudos é a leitura e análise literária. A falante $B$, mais ao final do episódio, demonstra responder com mais segurança aos questionamentos de A sobre a leitura e argumenta mais.

(12)

B: é o outro ELE/// é o segundo ele

A: $((\quad))^{30}$ que corpo/ que entrou em decomposição?

B: quando ele fala que elee oh/ que ele fala que ele tinha se visto lá na poltrona ¿lembra?/ tá/ aí ele fala (( o aviso não é) $)^{31}$ que ele/ que ele sabia que alguma coisa estava esperando

\footnotetext{
${ }^{30}$ Leitura.
}

${ }^{31}$ Leitura 
ele a noite ((esbarrou na minha pele $))^{32} /$ a minha pele a pele do outro eu dele// que quando ele fala do outro eu dele ele fala como se fosse o próprio corpo mas/ ((dou uma cotovelada no estômago a resposta é um soco que me derruba na cama) $)^{33}$ é aquele eu imaginário que ele tá vendo/ É TUDO imaginário aqui/ ele não matou ninguém $\downarrow / /$ eu acho que ele não matou $\downarrow$

A: eu também acho que ele não matou

(BRASL07/12/2009)

Observamos que B enuncia, em um primeiro momento, de maneira direta a sua opinião sobre o texto literário que estão analisando - "ele não matou ninguém $\downarrow$ " - e, em seguida, autorrepete-se - "eu acho que ele não matou $\downarrow$-, neste caso, atenuando a força argumentativa com relação à certeza do enunciado, ao grau de conhecimento ou ao seu compromisso com o que foi dito com "eu acho". Essa expressão de dúvida viabilizada pelo verbo performativo "achar" pode representar uma tática que subtrai responsabilidade, que previne ou que repara, protegendo assim as imagens tanto da falante, como da ouvinte.

Curioso é observar que esses movimentos de reformulação e atenuação não se apresentam da mesma maneira momentos antes da ocorrência da sequência analisada acima (12) durante esse diálogo. No fragmento a seguir (13), a estudante $B$, que nesta relação assimétrica demonstra mais conhecimento da matéria, corrige a A de maneira direta:

(13)

A: (...) pois é exatamente quando se encerram sua atividades cotidianas domésticas/ que de certa forma o conectam com o mundo real/// que surgem suas alucinações e a quase obrigação/ decorrentes da quase obrigação// e da necessidade dee se enxergar a si próprio/ de conviver com ele mesmo

B: ${ }^{34}$

A: decorrentes/ sei lá/ porque essas aí/ essas aí/ essas alucinações/ elas decorrem do convívio dele com ele próprio ¿né?

B: ISSO é a alucinação/ ela não é uma/ isso não é uma decorrência da alucinação/ isso É a alucinação/// que porque conviver com si próprio não é ((viver)) na cama se sentir na cama é se bater// isso JÁ é alucinação//

A: ((que surgem suas alucinações/// pois é quando exatamente se encerram suas atividades cotidianas domésticas/ que de certa forma o conectam com o mundo real/ quando elas se encerram surgem suas/suas/suas alucinações) $)^{35}$

B: ahn ahn

A: ¿e essas alucinações são decorrentes do quê?/// do contato dele com ele próprio

\footnotetext{
${ }^{32}$ Leitura.

${ }^{33}$ Leitura.

${ }^{34}$ Afirma através de um gesto com a cabeça.

${ }^{35}$ Leitura da resposta que está redigindo.
} 
B: ¡NÃO!/ o contato dele com ele próprio É a alucinação/ é decorrente dele tá sem fazer NADA ele fica sem fazer nada/ ele não tá ocupado ele começa (( )) ficar louco (SORRISO)

A: ${ }^{\circ}$ (então vamos reescrever isso aqui) ${ }^{\circ}(\ldots)$

(BRASL07/12/2009)

Em "ISSO é a alucinação/ ela não é uma/ isso não é uma decorrência da alucinação/ isso É a alucinação/// que porque conviver com si próprio não é ((viver)) na cama se sentir na cama e se bater $\downarrow / /$ isso JÁ é alucinação//", a falante $B$ intensifica o seu desacordo com $A$ com pronúncia marcada e enfática, destacadas na transcrição com letras maiúsculas. A intensificação se vincula à força argumentativa e constitui uma estratégia que a falante $B$ utiliza para reforçar o conteúdo locutório e ilocutório, para fazer valer a sua intenção.

Nesta sequência, aspectos não verbais como o dedo em riste de $B$, que chama a atenção para a sua explicação, também é uma estratégia para influenciar a interlocutora, que se mostra de cabeça baixa e começa a ler em silêncio, coloca a mão sobre a boca e parece refletir enquanto escuta a correção da colega.

Imagem 1 - Desacordo - (BRASL07/12/2009)

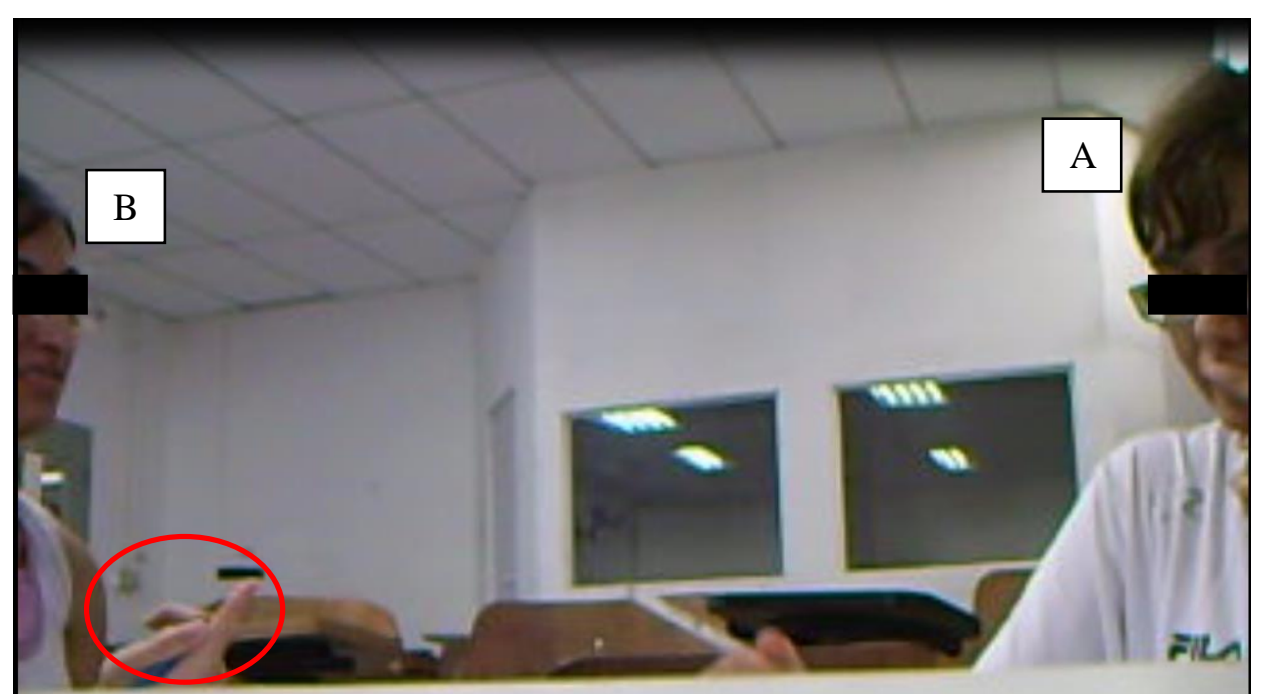


Além disso, B emprega a repetição em "ISSO é a alucinação/ ela não é uma/ isso não é uma decorrência da alucinação/ isso É a alucinação" e uma asserção comparativa irônica em "porque conviver com si próprio não é ((viver)) na cama se sentir na cama e se bater".

Na sequencia, ao notar que A não foi convencida, B diz "NÃO!/ o contato dele com ele próprio $E$ a alucinação/ é decorrente dele tá sem fazer NADA ele fica sem fazer nada/ ele não tá ocupado ele começa (( ) ficar louco". Não há mitigação da negação, mas sim intensificação por pronúncia acentuada - "NÃO" -, além das repetições hiperbólicas - "tá sem fazer NADA ele fica sem fazer nada" - e além das asseverações diretas - "o contato dele com ele próprio É a alucinação". A falante intensifica manipulando o que diz com esses operadores de valor semântico e pragmático.

No final desta amostra, a interlocutora A aceita a opinião de B - "então vamos reescrever isso aqui" - e não enuncia contra-argumentação, provavelmente porque $A$ e $B$ valorizam a imagem de hierarquia neste contexto. Assim, não interpretamos que, nesta interação, houve conflito social expresso, mas a falante B não demonstra reforçar a conciliação e a negociação, pois está respaldada pelo poder social nesta situação comunicativa. Todavia, chama-nos a atenção o sorriso com o qual B finaliza o seu enunciado - "ele não tá ocupado ele começa (( )) ficar louco (SORRISO)", como vemos na imagem 2.

Imagem 2 - Atitude não-verbal - (BRASL07/12/2009)

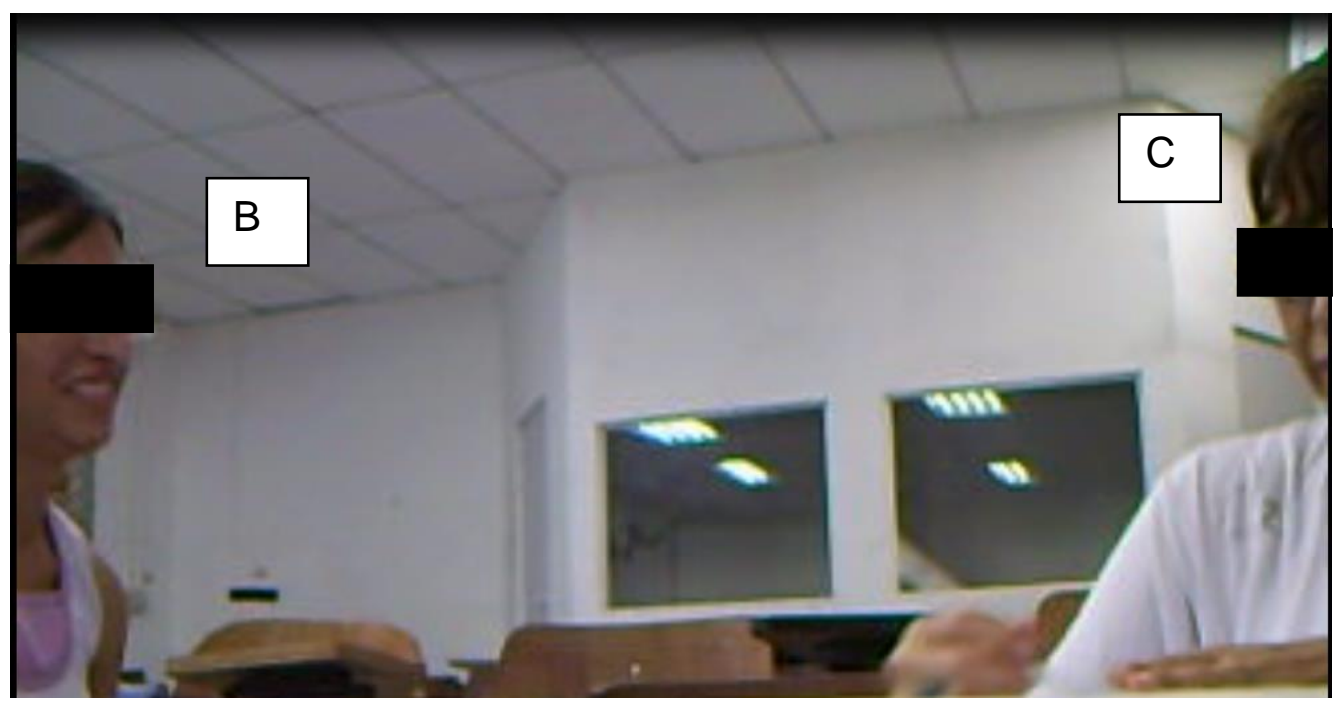


Pela gravação, neste momento, é possível notar que este sorriso aproxima-se de uma risada, mas emitiu um som muito breve e em volume bastante baixo, parecendo inclusive que a ouvinte $A$ não o percebeu. Apesar disso, eventualmente, essa atitude não verbal de $B$, de sorrir, poderia buscar mitigar as ameaças à face de sua interlocutora e à própria.

Vamos examinar a seguir uma sequência argumentativa, em que a repetição ocorreu no processo formulativo de um enunciado inserido num encontro em que há nove estudantes de jornalismo da USP, que se reúnem periodicamente para a elaboração de artigos.

D : §é / que nem a gente tem uma conta no wordpress / a gente não paga e tem a conta / não sei como $\S$

I:

D: não / então / mas teoricamente já venceu a conta do wordpress

I: não /mas a gente/gente paga o post daqueles sites $\S$

D:

F:

a gente não paga // é outro email que a [gente paga]

$\S$ não / wordpress§

D: [maxpress]§

I: $\quad$ Sé / é o domínio doß

D: $\quad \S$ é o maxpress / consultoria de imprensa // a gente tem um acordo com a maxpress de imprensa // beleza // bom enfim / próxima pauta (...)

(BRAABCDEFGHI29/04/2015)

A falante $D$ é quem, neste momento, detém a voz instrutiva e organiza a reunião. Nesse fragmento, D reformula suas ideias prevendo possíveis desacordos - "não / então / mas teoricamente já venceu a conta do wordpress" ao que o falante I, com uma resposta direta, também introduzida pela negação, expressa o desacordo sem a presença de atenuação para prevenir possíveis conflitos - "não/mas a gente /gente paga o post daqueles sites§". A falante D imediatamente responde da mesma maneira, com uma resposta direta encabeçada por "não", sem expressar cortesia - §não / wordpress§ -, mas tem seu turno assaltado. Não há proteção de imagens neste momento. 
Passamos agora à exposição sobre o material de análise chileno. Destacamos que os mesmos fenômenos apresentados sobre o material de análise brasileiro não foram encontrados nos contextos de Santiago do Chile.

Do corpus chileno, selecionamos para a análise um evento em que participam sete estudantes da faculdade de educação. Durante todo o encontro, não se levantou somente um aluno que se posicionasse hierarquicamente como "aluno-professor", mas sim, em variadas sequências, possivelmente devido às mudanças de tópicos conversacionais, jovens diferentes dominavam mais os turnos e controlavam mais a interação verbal. Em (15), temos:

(15)

D: es como contexto / es contextualizarnos un poco $\downarrow$ / en- en cómo nació / y/ ir viendo por ejemploo / a su vez cómo se va desarrollando / y bajoo quee / como qué marco está po cachai // entonces si YAA / la alfabeti- osea / alfabetizamos la gente que viene ahora / // en cómo se va adecuando la $\operatorname{SIP}^{36}$ a esto también po $\downarrow \S$

B: $\quad \S$ de hecho hace poco la SIP integró en el dos mil uno creó / integró el tema de la educació media / tenían puros colegios básicos / ¿o no?

E: noo noo

B: $(())$

E: crecieron la- crecieron los colegios $(())$

B:ya $\downarrow / /(($ ahí en el dos mil))

E: claro $\downarrow /$ por ahí $\downarrow$

B: [ya] $\downarrow$

A repetição da negação e o desacordo intensificado em "noo noo", também pelo alongamento das vogais, é uma estratégia pragmática viabilizada pela valorização da imagem de excelência e hierarquia do falante $E$, que parece pensa deter a informação mais fiável no momento sobre se a SIP (Sociedad de Instrucción Primaria de Santiago) se ocupava somente de colégios de ensino fundamental. A falante $B$, que tem o conteúdo de seu enunciado corrigido por $E$, expressa acordo com quem a corrige, diretamente - "ya $\downarrow$ // ((ahí en el dos mil))" - , turno em que a partícula "ya" "marca o início de uma intervenção, revela o seu caráter reativo e atua como veículo para expressar o acordo" (Andrade, 2010: 140).

\footnotetext{
${ }^{36}$ A Sociedad de Instrucción Primaria de Santiago (SIP) é uma corporação educacional chilena sem fins lucrativos, fundada com o objetivo de melhorar a qualidade e cobertura da educação escolar em comunidades carentes.
} 
Em muitos mais casos, no corpus chileno, essa dinâmica de correção de um falante a outro se deu de maneira direta e espontânea, isto é, sem que antes haja ocorrido algum marcador de controle de contato ou se tenha solicitado previamente a avaliação do conteúdo proposicional de alguma intervenção. Observamos, no total do corpus chileno 61 casos de correção, dos quais apresentaram recursos de atenuação (creo, debería, sería, no sé, es que etc.) 8 deles (13\%). A seguir, dois fragmentos nos quais o fenômeno de autorrepetição, destacado em negrito, participou do processo formulativo.

(16)

A: pero se marca solo o se marca / personalmente A los papeles de Lucy comoo

B: noo poo pero// se marca / pero es que tu puedes ver sii

A: [ pero entonces] pero es que este profe va marcando así como si hubiera sido todo dentro pu

B: $\quad$ [pero es que / Loreto] /Loreto es que tú podí decir echar un vistazo a los papeles de Lucy $\uparrow$ y echar un vistazo personalmente $\downarrow$

A: dale / entonces / complemento directo $\uparrow$ sintagma nominal

A: y eso va / es complemento de modo de insistir o echar un vistazo

C: $\mathrm{mmm} /$ dee / echar un vistazo

D: ya / tú no lo hiciste personalmente

C: imagínate que no esta toa la / la oración que quee

B: sí puee insistir personalmente

D: no pero es que tu sabís que aquí está está está echando un vistazo personalmente

A: noo no creo

A: $[((\mathrm{el}))(())(\mathrm{el} \mathrm{de} / \mathrm{el}$ de haberlo es persona) $)]$

B: [ ((no es verbo echado es deficiente $))(())]$

A: entonces el verbo es echar un vistazo

D: noo pu / mujer // entiende / personalmente está / parte de todo el suplemento / ¿cachai? $/ /{ }^{\circ}$ (ay señor esta niñita $)^{\circ}$

A: ya $\downarrow$ no si ya entendí ya entendí / es como / es como una cláusula subordinada

B: [oye y esto ¿((te lo enterraste tú))?]

D: ES una oración subordinada

A: dale

D: porque de hecho es una oración subordinada sustantiva ((locución prepositiva))

A: [noo nono me ((me lo enterré $))]$

(17)

B: esto trae- acarrea confusión / trae confusión? $\uparrow$

C: acarrea $\rightarrow$

B: ¿acarrea? $\uparrow$

$5 "$

B: lleva conduce / (())

C: $[(())]$

A: pero es que traE $\uparrow$ / trae eh muy / tal cual $\uparrow$

B: acarrea tambiéen

C: también eh muy tal cual 
No exemplo (16), observamos três estudantes de Letras que realizam a análise sintática de orações. As dissensões e a orientação argumentativa são bastante presentes nesta sequência, há correções espontâneas não atenuadas e intensificadas pela repetição léxica - "noo no". Inclusive a imagem de excelência da falante A é ameaçada em "noo pu (pues) / mujer // entiende / personalmente está / parte de todo el suplemento / ¿cachai? // 'ay señor esta niñita)", e esta aceita a proposta de correção de maneira intensificada, a partir da autorrepetição - "ya $\downarrow$ no si ya entendí ya entendí".

Os participantes do exemplo (17) são quatro estudantes do curso universitário de tradução e estão reunidos em um ambiente informal, concentrados na finalização de uma apresentação que está sendo redigida em um computador. Notamos que A corrige uma opção de tradução em "pero es que traE $\uparrow$ / trae eh muyy / tal cual ", marcando a orientação argumentativa com "pero", que introduz seu turno. A pausa existente depois de "es que traE $\uparrow$ " pode revelar que, neste momento, havia certo planejamento do discurso, lugar propício para a ocorrência da atenuação, um ato consciente, através do operador tático "es que", que autoprotege o falante e busca prevenir ameaças às faces ou problemas causados pela intromissão ou invasão do território ou espaço. Entretanto, esta estratégia foi logo abandonada, após a pausa, pela clareza da intensificação com o quantificador "muy" - "trae eh muyy / tal cual", reafirmando a sua capacidade de persuasão diante dos demais, neste jogo de imagens.

A amostra seguinte pertence a um episódio em que interagem cinco estudantes de jornalismo, quatro mulheres e um homem, e o fenômeno da repetição ocorre numa sequência argumentativa, antes do início do período de estudos em si. Os estudantes discutem se a porcentagem de presença dos alunos de determinada disciplina é de sessenta ou setenta por cento, segundo o que disse ou não um professor em aula: 
(18)

A: (¿pero no que esto eh lo que pide la escuela?)

B: pero eso eh lo que dijo en el programa $\uparrow$

A: sí po / y dijoo / y dijo / setenta por ciento de (())

C: [igual el profesor dijo $(())]$

B: [pero no podría $(())$ / no podría haceerlo porque nosotroh / porque la mayoría tiene problemaah dee asistencia

C: [ssíi se puede]

D: pero (Cote si) el diijo / la primera clase / que era setenta por ciento (())

A: [no po si / eso eso lo aclaró despuéh // eso eso] lo aclaró dijo // no si / setenta por ciento es lo que pide la escuela / (()) no voy a estar pidiendo / y yo le dije pero profe / usted dijo sesenta $\downarrow$ / y El

?: [y] dijo // no $\uparrow$ / si eso eh lo que voy a pedir yo / y punto $\downarrow$

Devemos notar as frequentes sobreposições de falas nesse fragmento, marcadas por [ ], o que revela que o processo argumentativo nessa conversação. A autorrepetição da falante A em "sí po ${ }^{37}$ / y dijoo/ dijo/ setenta por ciento de (...)" nos parece que intervém na atividade formulativa do seu enunciado e o marcador de modalidade "sí po" intensifica a força ilocutória desse ato de fala.

Nessa amostra, vemos a atuação da partícula "pero", determinante na orientação argumentativa de vários enunciados aos quais introduzem os falantes - "A: (¿pero no que esto eh lo que pide la escuela?)"; "B: pero eso eh lo que dijo en el programa P”; "B: [pero no podría (()) / no podría haceerlo porque nosotroh / porque la mayoría tiene problemaah dee asistencia" e "D: pero (Cote sí) el diijo / la primera clase / que era setenta por ciento". Esses falantes expressam o desacordo e, notamos que uma asserção de B sofre atenuação por modificação do verbo performativo "poder" - "no podría haceerlo(...)". Essa mitigação se trata de uma atividade do falante, não envolve a proteção de imagens dos ouvintes, constitui-se uma estratégia para prevenir possíveis danos à própria imagem quanto à responsabilidade do que diz, classificada como um mecanismo autocêntrico (Fant e Granato, 2002).

\footnotetext{
$37 \mathrm{Na}$ variedade chilena, o marcador discursivo pues possui a variante po, que surgiu a partir de um fenômeno de abreviação, acarretado pela produção da aspiração do /s/ final de sílaba, traço muito presente no espanhol falado no Chile, e também pela elisão, ou seja, a supressão de uma vogal em contato com outra, resultando na perda da ditongação, o que gerou uma síncope: pues < pue < po (Andrade, 2010).
} 
Não só o desacordo sofre intensificação como o acordo. Observemos o próximo fragmento, pertencente ao mesmo encontro de estudo, em que a falante $\mathrm{C}$ expresa $\mathrm{O}$ acordo à falante $\mathrm{A}$, na verdade, desde $\mathrm{o}$ início desse episódio é possível notar que compartilham de opiniões convergentes:

(19)

C: [a ya miRA] $\downarrow /(())$ / lo último / la última clase decía / estaba comparando el feminismo cachai en la publicida' / decía cosah así / que yo estaba así / absolutamente en desacuerDO $\uparrow /$ como que la publicidah $\uparrow$
A:
$[(())]$
B:
[sí]

/ eraa / trataba de convencer a la gente / manipulaarla y que el periodismo no / no ((vai a hacer una comparación)) entre que la publicidad era comercial $\uparrow$ / el (()) le dijo quee el periodismo también se puede $(()) /$ a NO po pero $((())$

A: [no eeh que] / lo que pasa es quee $\rightarrow /$ no (eh eso) $\S=$

B: § el diálogo

A: = yy claro / y dijoo- dijo / el mayor problema del periodismo hoy en DÍA / es / la publiciDA' $\downarrow$ / porque manipulaa / está manipulando- trabajando sobre loh contenidoh $\rightarrow \S$ B: $\S[$ claro] / como que la pu-publicida(d) mermaba el periodismo / pero / que despuéh el periodismo era BUeno sí / y tiene / y tiene] en sí mismo $\downarrow$ / pero que era malo como lo hacían / pero uno puede decir lo mismo de la publicidah po $\downarrow$

C: [obvio $\uparrow]$

A: [yo le dije]

B: que la publicida' puede ser buena en sí misma pero también se merma por los intereses económiicoh no sé $\uparrow$

A: es que yo le- yo le / no eh que / síi po / pero es que yo le dije quee / quee / él tenía la noción de que había / existido algunn- alguna vez / un periodismo comoo =

C: sí po como (())

(V10)

Nessa conversação, o processo argumentativo é enfocado, assim, a falante A, com o fim de alcançar as suas metas interacionais e de fazer com que seus interlocutores compreendam e, principalmente, apóiem o que diz, utiliza-se do fenômeno da autorrepetição ao formular a sua mensagem.

A falante $C$ reafirma o que $A$ diz com "obvio $\uparrow$ " com uma sobreposição de turnos cooperativa, modaliza o seu enunciado e indica o acordo na segunda parte de um par adjacente, manifestando cortesia valorizadora e intensificando o acordo. Seguramente, a falante $\mathrm{C}$ reafirma a própria imagem e a da destinatária, mais especificamente os componentes de cooperação como também de excelência. A expressão da conformidade com um ponto de vista formulado pelo interlocutor produz um efeito perlocutivo de cortesia, reforça a imagem de afiliação e valoriza a cortesia de solidariedade. 
2.1.1.1.2. Apresentação dos resultados: a autorrepetição e as estratégias de cortesia envolvidas na construção da imagem dos participantes da interação brasileira e chilena

Após a realização dessa análise, em que nos centramos em descrever e contrastar as estratégias de cortesia em português e espanhol que se envolveram na autorrepetição, constatamos que esse fenômeno, em atos assertivos, pode estar vinculado à expressão do grau de capacidade intelectual por um lado e, por outro, no reforço da imagem de hierarquia e de excelência nos materiais de análise de São Paulo e de Santiago do Chile.

Em ambos materiais, chileno e brasileiro, a autorrepetição ocorre com frequência no discurso do falante que detém a voz instrutiva, favorecendo a sua imagem de hierarquia, em geral, operando no processo formulativo da mensagem. Como estratégia pragmática, para produzir uma linguagem mais eficiente ou precisar ideias, o falante que se autorrepete muitas vezes busca facilitar a compreensão por parte de seu(s) ouvintes(s) enquanto constrói seu enunciado. Em alguns casos, também é uma estratégia de ênfase com o fim de insistir na importância de alguma informação ou ponto de vista.

Mecanismos de intensificação se destacam vinculados à força argumentativa e fazem parte das estratégias que os falantes, brasileiros e chilenos, utilizam para reforçar o conteúdo locutório e ilocutório de seus atos de fala. Tais mecanismos são viabilizados pela valorização da imagem de excelência e hierarquia do falante. Pronúncia enfática, repetições hiperbólicas, advérbios etc., participam da orientação argumentativa na expressão do desacordo em alguns casos.

Nesse sentido, vimos também que, tanto nos contextos brasileiro e chileno analisados, a autorrepetição pode participar da estratégia pragmática de intensificação num ato de correção do conteúdo proposicional do turno do ouvinte. Porém, no corpus brasileiro, frisamos a presença de movimentos de justificação por parte do ouvinte que é corrigido, podendo expressar o acordo com o falante após 0 ato de correção, manifestando atenuação estratégia de autoproteção. O marcador "ah é", no turno do ouvinte, frequentemente introduz, 
neste contexto, uma unidade do discurso, numa estratégia afirmativa de evitar prejuízos à sua imagem de excelência, pois não demonstrar conhecimento também ameaça sua imagem de cooperação com base em que um objetivo social primordial em um evento como o encontro para o estudo é mostrar-se como membro cooperativo.

Em situações análogas chilenas, não encontramos semelhante gestão das imagens ou mecanismos de justificação quando o interlocutor recebe uma correção, mas sim muitas vezes observamos a aceitação direta do ouvinte, cujo turno pode ser introduzido pela partícula modalizadora "ya", que marca o início de uma intervenção, revela o seu caráter reativo e atua como veículo para expressar o acordo.

Em muitos mais casos, no corpus chileno e brasileiro, apresentaram-se dinâmicas de correção de um falante a outro de maneira espontânea, sem que antes haja ocorrido algum marcador de controle de contato ou prévia solicitação de avaliação. Do total do corpus, temos 26 casos nas interações brasileiras e 61 casos nas chilenas; desses casos, $23 \%$ das intervenções dos falantes brasileiros que enunciaram a correção foram atenuadas, nas quais, possivelmente o riso poderia representar uma estratégia paralinguística de mitigação, e 13\% dos falantes chilenos atenuaram as suas intervenções.

Entretanto, devemos considerar que há também frequentes casos em que notamos uma abertura para que a correção ocorra, nas interações chilenas analisadas, como “¿o no?”, no final do turno do falante que chama a atenção do ouvinte sobre a informação que é comunicada previamente. Certamente há mais ameaças às faces se apelativos não ocorrem e quando, a partir da expressão de algum desacordo, fortalece-se a orientação argumentativa.

No corpus em português, a gestão interrelacional revelou a maior presença de estratégias afirmativas das imagens de cordialidade, semelhança e cooperação. Nesse sentido, nas conversações do corpus de São Paulo, as sequências selecionadas em que ocorrem autorrepetições, na sua maioria, manifestam estratégias de atenuação, muitas delas envolvidas com a cortesia.

Os mecanismos de atenuação encontrados no corpus de São Paulo, na maior parte das vezes, indicam hesitação ou distanciamento da mensagem, para que o falante evite a responsabilidade sobre o que diz, minore a força ilocutória, a força da certeza do enunciado ou do grau do conhecimento. Esses operadores 
podem sugerir a abertura e o intercâmbio de ideias e opiniões, uma vez que a atenuação da força ilocutória pode valorizar a imagem de cooperação e possibilitar a negociação. A atenuação, portanto, associa-se à cortesia e favorece as estratégias afirmativas da imagem do interlocutor, o que valoriza sua imagem de semelhança e, ao mesmo, torna-se um escudo protetor de sua imagem de cordialidade; se consideramos que mostrar-se pouco impositivo é um valor social nessa comunidade de fala.

No corpus chileno, a atenuação participou com mais frequência na atividade do falante, não contemplando a proteção de imagens dos ouvintes, mas sim se constituindo uma estratégia para prevenir possíveis danos à própria imagem quanto à responsabilidade do que diz, o que é um mecanismo autocêntrico.

Com a autorrepetição no corpus brasileiro, notamos repetidas vezes a presença de marcadores conversacionais de controle de contato que buscam 0 apoio discursivo. Essas partículas podem solicitar uma confirmação do que foi dito antes ou chamar a atenção do ouvinte sobre a informação comunicada previamente e que é apresentada como se fosse compartilhada por este. Também podem reforçar assim a imagem de cooperação, embora esses operadores pragmáticos, por seu valor exortativo, possam manifestar também certo valor argumentativo, sinal do apelo do falante para que o ouvinte adote a sua linha de pensamento.

Em seguida, serão apresentados quadros que resumem os mecanismos de manutenção do equilíbrio na interação social, em encontros de estudo no âmbito acadêmico observados no material de análise. 
QUADRO 1 - AUTORREPETIÇÃO E ESTRATÉGIAS DE CORTESIA ENVOLVIDAS NA CONSTRUÇÃO DA IMAGEM DOS PARTICIPANTES DE GRUPOS DE ESTUDOS ACADÊMICOS EM SÃO PAULO (BRASIL)

\begin{tabular}{|c|c|c|}
\hline $\begin{array}{c}\text { FENÔMENO } \\
\text { LINGUÍSTICO EM ATOS } \\
\text { ASSERTIVOS }\end{array}$ & $\begin{array}{c}\text { PAPÉIS PRAGMÁTICOS } \\
\text { Em geral, podem manifestar-se juntamente com a autorrepetição: }\end{array}$ & EXEMPLOS \\
\hline \multirow[t]{2}{*}{$\begin{array}{l}\text { Autorrepetição (falante): } \\
\text { Ocorre com frequência no } \\
\text { discurso do falante que detém } \\
\text { a voz instrutiva, favorecendo } \\
\text { a sua imagem de hierarquia. } \\
\text { Em geral este fenômeno } \\
\text { opera no processo } \\
\text { formulativo. Como estratégia } \\
\text { pragmática, para produzir } \\
\text { uma linguagem mais eficiente } \\
\text { ou precisar ideias. O falante } \\
\text { que se autorrepete muitas } \\
\text { vezes busca facilitar a } \\
\text { compreensão por parte de } \\
\text { seu(s) ouvintes(s) enquanto } \\
\text { constrói seu enunciado. Em } \\
\text { alguns casos, também é uma } \\
\text { estratégia de ênfase com o } \\
\text { fim de insistir na importância } \\
\text { de alguma informação ou } \\
\text { ponto de vista. }\end{array}$} & $\begin{array}{l}\text { 2) mecanismos de atenuação que indicam hesitação ou distanciamento da } \\
\text { mensagem, para que o falante evite a responsabilidade sobre o que diz, } \\
\text { minore a força ilocutória, a força da certeza do enunciado ou do grau do } \\
\text { conhecimento. Esses operadores podem sugerir a abertura e o intercâmbio de } \\
\text { ideias e opiniões, uma vez que a atenuação da força ilocutoria pode valorizar } \\
\text { a imagem de cooperação e possibilitar a negociação. A atenuação se associa à } \\
\text { cortesia e favorece as estratégias afirmativas da imagem do interlocutor o que } \\
\text { valoriza sua imagem de semelhança e, ao mesmo, torna-se um escudo } \\
\text { protetor de sua imagem de cordialidade, se consideramos que mostrar-se } \\
\text { pouco impositivo é um valor social nessa comunidade de fala. }\end{array}$ & $\begin{array}{l}\text { A: são expectadores pode-se dizer } \\
\text { B: espectadores } \\
\text { A: é/ porque vai depender/ você pode escrever até } \\
\text { ¿né? de acordo com o evento/ os espectadores } \\
\text { vão ser de um tipo/por exemplo no::/ sei lá/eh::/ } \\
\text { panegírico// (vo)cê vai ter um tipo de espectador// } \\
\text { um tipo de espectadores/ se for um:: dis/ um:/ uma } \\
\text { homenagem fun-um discurso fúnebre ique se } \\
\text { fala?// uma oração fúnebre/ vai ser outra coisa/ e } \\
\text { assim por diante/ aí você/ ponto final/ aí no } \\
\text { próximo parágrafo/ você coloca assim/ Aristóteles/ } \\
\text { ainda// eh::/ ainda fez uma classificação de acordo/ } \\
\text { com/ com o que ele precisava no discurso/ cada um } \\
\text { desses três gêneros / ¿não é isso? } \\
\text { B: é:: } \\
\text { (BraFAFB03/12/2009) }\end{array}$ \\
\hline & $\begin{array}{l}\text { 3) mecanismos de intensificação que se vinculam à força argumentativa e } \\
\text { fazem parte das estratégias que os falantes utilizam para reforçar o conteúdo } \\
\text { locutório e ilocutório de seus atos de fala. Tais mecanismos são viabilizados } \\
\text { pela valorização da imagem de excelência e hierarquia do falante. Pronúncia } \\
\text { enfática, repetiçães hiperbólicas, advérbios etc., participam da orientação } \\
\text { argumentativa na expressão do desacordo em alguns casos. A autorrepetição } \\
\text { também pode participar da estratégia pragmática de intensificação num ato }\end{array}$ & $\begin{array}{l}\text { A: decorrentes/ sei lá/ porque essas aí/ essas aí/ } \\
\text { essas alucinações/ elas decorrem do convívio dele } \\
\text { com ele próprio ¿né? } \\
\text { B: ISSO é a alucinacão/ ela não é uma/ isso não é } \\
\text { uma decorrência da alucinação/ isso É a } \\
\text { alucinação/// que porque conviver com si próprio } \\
\text { não é ((viver)) na cama se sentir na cama é se }\end{array}$ \\
\hline
\end{tabular}




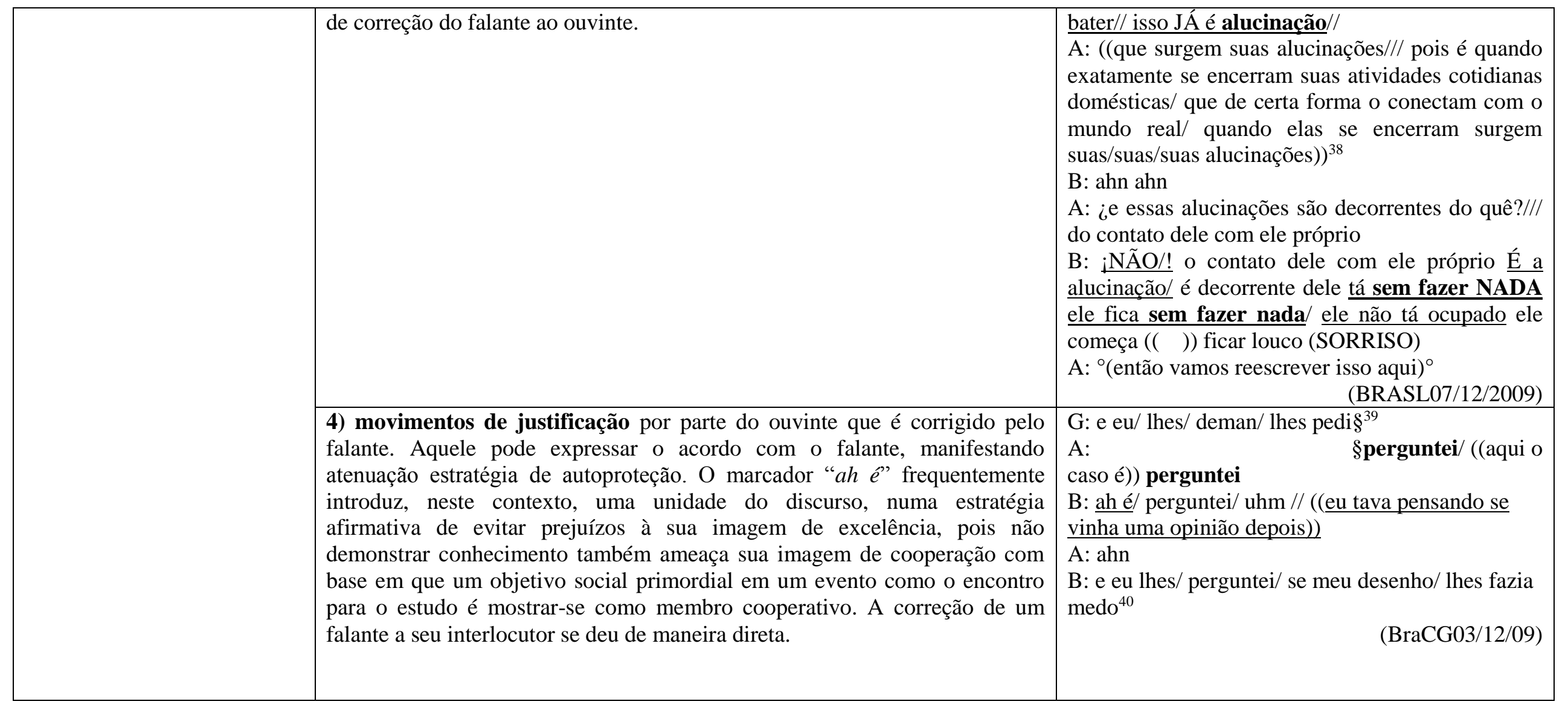

${ }^{38}$ Leitura da resposta que está redigindo.

${ }^{39}$ Lendo e traduzindo um texto em francês.

40 Idem. 
QUADRO 2 - AUTORREPETIÇÃO E ESTRATÉGIAS DE CORTESIA ENVOLVIDAS NA CONSTRUÇÃO DA IMAGEM DOS PARTICIPANTES DE GRUPOS DE ESTUDOS ACADÊMICOS EM SANTIAGO DO CHILE

\begin{tabular}{|c|c|c|}
\hline $\begin{array}{c}\text { FENÔMENO LINGUÍSTICO EM ATOS } \\
\text { ASSERTIVOS }\end{array}$ & $\begin{array}{c}\text { PAPÉIS PRAGMÁTICOS } \\
\text { Em geral, podem manifestar-se juntamente com } \\
\text { a autorrepetição: }\end{array}$ & EXEMPLOS \\
\hline $\begin{array}{l}\text { Autorrepetição (falante): } \\
\text { Ocorre com frequência no discurso do falante que } \\
\text { detém a voz instrutiva, favorecendo a sua imagem de } \\
\text { hierarquia. Em geral este fenômeno opera no } \\
\text { processo formulativo. Como estratégia pragmática, } \\
\text { para produzir uma linguagem mais eficiente ou } \\
\text { precisar ideias. O falante que se autorrepete muitas } \\
\text { vezes busca facilitar a compreensão por parte de } \\
\text { seu(s) ouvintes(s) enquanto constrói seu enunciado. } \\
\text { Em alguns casos, também é uma estratégia de ênfase } \\
\text { com o fim de insistir na importância de alguma } \\
\text { informação ou ponto de vista. }\end{array}$ & $\begin{array}{l}\text { 1) mecanismos de intensificação que se } \\
\text { vinculam à força argumentativa e fazem parte } \\
\text { das estratégias que os falantes utilizam para } \\
\text { reforçar o conteúdo locutório e ilocutório de } \\
\text { seus atos de fala. Tais mecanismos são } \\
\text { viabilizados pela valorização da imagem de } \\
\text { excelência e hierarquia do falante. Pronúncia } \\
\text { enfática, repetições hiperbólicas, advérbios, etc, } \\
\text { participam da orientação argumentativa na } \\
\text { expressão do desacordo em alguns casos. O } \\
\text { acordo também pode sofrer intensificação, neste } \\
\text { caso, manifesta-se a cortesia valorizadora, como } \\
\text { também as imagens de cooperação e de } \\
\text { excelência, podendo valorizar-se a cortesia de } \\
\text { solidariedade. } \\
\text { A autorrepetição também pode participar da } \\
\text { estratégia pragmática de intensificação num ato } \\
\text { de correção do falante ao ouvinte. Este, que tem } \\
\text { o conteúdo de seu enunciado corrigido pode } \\
\text { expressar acordo com o falante diretamente, sem } \\
\text { a manutenção das faces. Seu turno pode ser } \\
\text { introduzido pela partícula "ya", que marca o } \\
\text { início de uma intervenção, revela o seu caráter } \\
\text { reativo e atua como veículo para expressar o } \\
\text { acordo. }\end{array}$ & 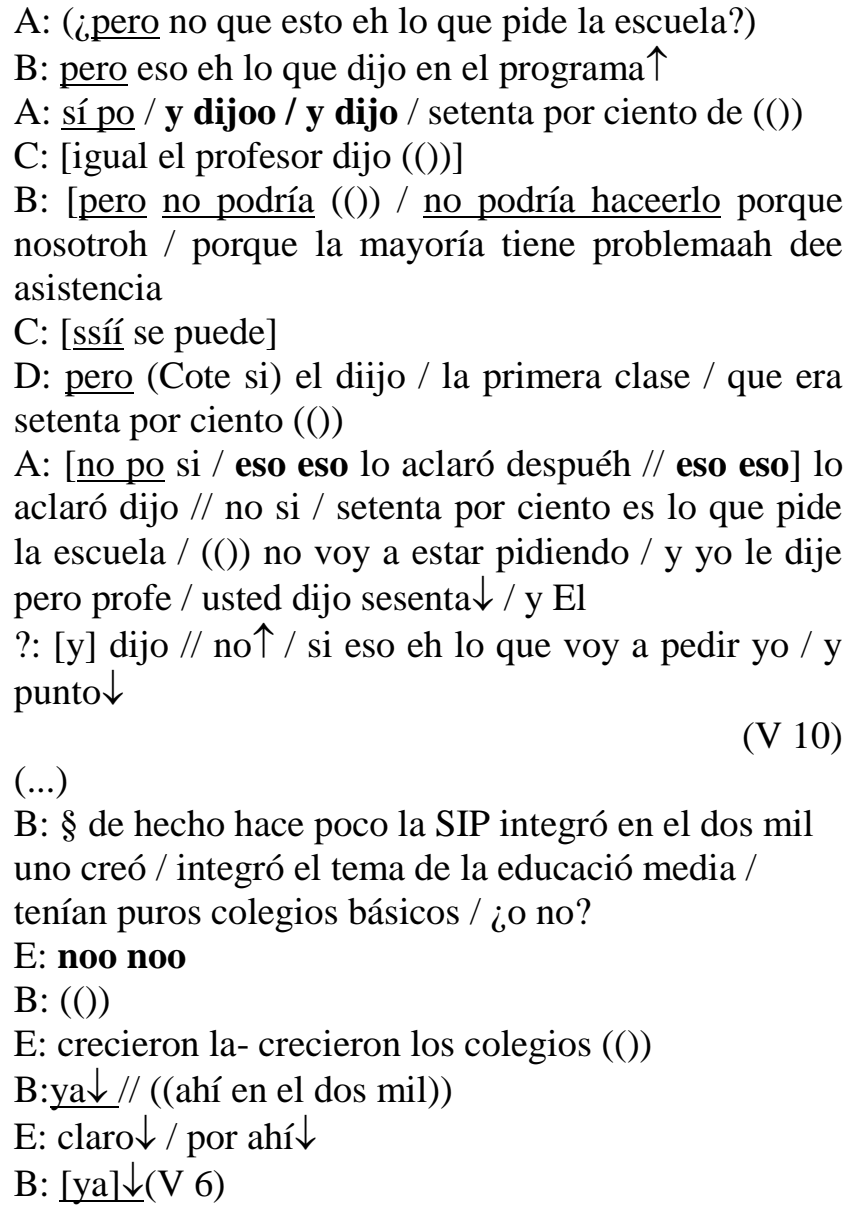 \\
\hline
\end{tabular}


C: [ssíí se puede]

autocêntrico (FANT; GRANATO, 2002). 


\subsection{Heterorrepetição}

Como dissemos, na seção anterior, a repetição pode funcionar como um processo de reconstrução e ter como função "sanar problemas detectados (pelo próprio locutor ou pelo parceiro) em seguimentos enunciados anteriormente: repete-se ou parafraseia-se o que foi dito, quando se percebe que o parceiro não compreendeu bem, para evitar mal-entendidos" (Koch, 2008). A repetição pode ser promotora da interação e carregar os sinais do ouvinte de aprovação e os indicadores do interesse pelo o que diz o falante (Silva, 2010).

Nesta etapa da pesquisa, selecionamos sequências conversacionais em que a heterorrepetição se manifestou em atos assertivos; nas interações brasileiras encontramos 91 casos e nas chilenas, 165 .

No corpus brasilero, e no chileno também, observamos que a heterorrepetição pode revelar a conformidade com um ponto de vista formulado pelo interlocutor, produzindo um efeito perlocutivo de cortesia, reforçando a imagem de afiliação numa estratégia discursiva que valoriza a cortesia de solidariedade.

(1)

A: quer dizer aa ele teve o sentimento e como se o sentimento nas pessoas/ não fizesse parte de ummm conjunto né? $\uparrow$ um aprendizado emocional/ que que tem a ver com essa cultura machista// então/e e agora/ mas é louco isso porque como a gente consegue pensar aa/ sei lá $\downarrow /$ no dia a dia do repórter/ que ele vai até na na delegacia aparece um caso desses/ e a cobrança é pra que ele chegue na redação com o caso né? $\uparrow$ e falar §o que aconteceu B:

§o que aconteceu

(BRAAV28/01/2014)

(2)

B: é por isso/ é um crime de ódio $\downarrow /$ isso não tá claro $\downarrow /$ então/ isso não estando claro pra sociedade/ a imprensa nem questiona na hora de fazer a cobertura

A: é/ não tá claro $\downarrow / /$ acho que a opressão acaba se aa se infiltrando nos dois/ ela tá na imprensa e também tá na polícia da polícia afirmar isso sem menor questionamento/ quer $\operatorname{dizer} /(\ldots)$

(BRAAV28/01/2014) 
(3)

A: ¿pero y cómo? $\uparrow /$ ¿asociatividad cuánto era? $\uparrow$

C: autónoma $\downarrow$ / autonomía asociativa $\downarrow$

A: autonomía asociativa $\downarrow$ / ese es el concepto $\downarrow$ / autonomía asociativa $\downarrow$

Nas sequências argumentativas do corpus chileno e brasileiro, encontramos casos de heterorrepetição com a função de reforço da imagem do interlocutor. Estes resultados demonstram que o componente de imagem de cooperação com os interlocutores pode agir no trabalho das faces nas interações das comunidades de fala estudadas.

Vemos a seguir, numa amostra brasileira, que um ouvinte usa as palavras que o outro disse, repetindo-as e valorizando a imagem do falante. Neste encontro de estudos, temos duas estudantes de jornalismo, que conversam em uma cafeteria sobre um artigo que devem escrever a respeito da cobertura da imprensa de crimes, de opressão e/ou de desrespeito aos direitos humanos.

(4)

A: quer dizer aa ele teve o sentimento e como se o sentimento nas pessoas/ não fizesse parte de um nn conjunto né? um aprendizado emocional/ que que tem a ver com essa cultura machista// então/e e agora/ mas é louco isso porque como a gente consegue pensar aa/ sei lá/ no dia a dia do repórter/ que ele vai até na na delegacia aparece um caso desses/ e a cobrança é pra que ele chegue na redação com o caso né? e falar [o que aconteceu] $\mathrm{B}$ :

[o que aconteceu]

A: o que foi o que não foi e pronto// né? / e o próprio dia a dia do jornalismo acaba impedindo né? um nn / (...)

(BRAAB28/01/2014)

Esta gravação isoladamente possui 12 ocorrências de heterropetição em apenas vinte minutos em que durou a gravação do encontro e, segundo nossa análise, desempenham a estratégia de reforçar a cooperação e a co-construção do discurso, além de muitas vezes expressarem total acordo com o interlocutor, valorizando a imagem de cordialidade.

(5)

B: é por isso/ é um crime de ódio/ isso não tá claro/ então/ isso não estando claro pra sociedade/ a imprensa nem questiona na hora de fazer a cobertura

A: é/ não tá claro// acho que a opressão acaba se aa se infiltrando nos dois/ ela tá na imprensa e também tá na polícia da polícia afirmar isso sem menor questionamento/ quer dizer/ não é nem que aaa talvez nesse caso a polícia esteja realmente escondendo/ a gente 
não sabe o que aconteceu porque teve toda essa coisa da da mãe negaaa numa situação super §confusa

(BRAAB28/01/2014)

Entendemos que o fato de o diálogo contar com somente duas participantes pode fomentar a manifestação de estratégias afirmativas para proteger e fortalecer ativamente a alo- ou autoimagem, considerando que um valor social brasileiro é mostrar-se amigável, sociável e evidenciar respeito ao interlocutor.

Examinamos novamente o evento de encontro de estudos em que dois estudantes brasileiros, um jovem e uma jovem da Faculdade de Letras da USP, realizavam a tradução de um texto, período no qual a estudante $C$ detém a voz instrutiva. Observamos que, entre estes interlocutores, a heteterropetição participou 21 vezes (38\%), de um total de 54 casos somente nesta interação, no ato de demonstrar a aceitação do falante $G$ às respostas e/ou opções de tradução explicita, reforçando a imagem de hierarquia e excelência de $\mathrm{C}$ :

(6)

C: é ¿né?/((voici)) seria o o mais próximo/é porque/ ce lembra que eu te falei que o((voici)) e o ((voilà))/ eu suspeitava que era do/do verbo ver/ ver aqui [é:: ver lá] /

G:

[ver lá]

C: ¿¿né??/ então/ o ((voic)) é o que tá mais perto/ ¿né?/então/ ((voici))/ anh/ ((monfrère)) ¿¿né?? meu irmão

G: tá

(BRACG03/12/2009)

O falante $G$ expõe uma lógica relacional, age valorizando a conciliação e a aceitação dos enunciados de sua interlocutora. Porém, essa falante, também apóia constantemente seu colega. Repete o que ele diz por 9 (16\%) vezes nesta interação:

(7)

C: ((se eu não me engano/ ele começou/quer ver(( j'aicommencé"/ não/ (( )) / eu consegui

G: eu consegui comm/ [lápis de cor] traçar/ meu primeiro desenho

C:

[lápis de cor]

G: traçar

$\mathrm{C}$ : isso

G: meu primeiro desenho

C: ${ }^{\circ}(\mathrm{ahm})^{\circ}$ 
A falante $\mathrm{C}$ conta com a heterropetição léxica para valorizar a cortesia de solidariedade, o que se estabelece como estratégia afirmativa de valorização de sua imagem de cordialidade e cooperação.

Do total de encontros de estudos do corpus brasileiro, a heterropetição ocorreu na voz daquele que não detinha a voz instrutiva 47 vezes, ou seja, em $51 \%$ do total de casos de heterropetições, com o fim de apoiar ou reforçar o que seu interlocutor disse, como neste exemplo:

(8)

A: (es)távamos falando do auditório concorda eles tinham três tipos de auditórios/ (( )) são três gêneros ¿por quê?// porque eles têm auditórios [diferentes]

B: [diferentes] ((grupos)) diferentes

A: ¿qual o auditório de cada um?

B: dôoo deliberativo/ eeeh seria a assembléia/ ((que tem os seus)) políticos ¿né? seus cidadãos (( $\quad)$ ) ((e que tem como tempo principal o futuro))

(BRAAB03/12/2009)

Atentemo-nos, porém, para o fato de que em alguns casos a heterropetição, além de demonstrar a confirmação e apreciação do que foi dito, poderia representar uma estratégia de protegeção da imagem daquele que expressa menos conhecimento, como tentativa de mostrar-se cooperativo e frisar que a sua atenção está voltada a seu interlocutor e que a mensagem foi entendida, marcando o contato social.

A amostra seguinte é de uma conversação chilena, em que participam três alunas do sexo feminino do curso de licenciatura em história. Elas estudam sentadas em um gramado da universidade, ao ar livre. Ao ler a transcrição, foi bastante difícil identificar, entre as três falantes, qual mais detinha a "voz de professor", que demonstrava mais conhecimento, o que, como vimos na seção anterior, é um fator fundamental na construção das imagens dos interlocutores que são produzidas nas interações em estudo. A divisão de turnos deu-se de maneira equilibrada nesta transcrição $e$, de acordo com o tópico que desenvolvem, cada uma evidencia mais ou menos conhecimento da matéria, a depender do que estão falando.

Vendo o vídeo, porém, as relações interpessoais e a co-construção das imagens ficaram mais claras: as alunas estão respondendo a questões 
previamente escritas e entendemos que a falante $B$ estabelece com a falante $A$ mais afiliação e cooperação do que com a falante $C$, porquanto quase todos os seus turnos são dirigidos a A pelo olhar e manifestação corporal, pois gira um pouco a cabeça em direção a $A$ na maioria das vezes em que detém a palavra. Logo, parece que $B$ possui com $A$ uma relação mais próxima do que com $C$, inclusive $A$ e $B$ compartilham um cigarro, em um determinado momento, sem que haja um pedido prévio. Com base nesses fatores contextuais, analisamos 0 fragmento a seguir:

(9)

C: claro $\downarrow$ es que lo que pasa es que estos tres modelos son-es la relación asimétrica $\downarrow$ lo que

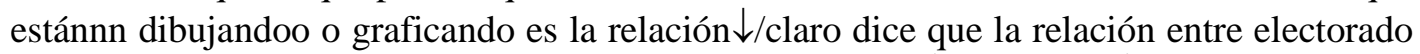
y-o partídoh políticoh o actoreh políticoh ES asimétrica $\uparrow /$;por qué? $\uparrow$ porque el po-los partidos políticoh o actoreh políticoh tienen el poder $\downarrow /$ y tie- y ha-hacen que la-el electorado se mueva [de acuerdo] a como ellos $\S$

A: $\quad[$ ah sí $(())] \quad$ el electorado see $\rightarrow$ comporta o mueve $=$ se mueven $\downarrow$

B: de cómo- [de acuerdo] a como [ellos/] entregan $\downarrow /$ esta [infor]mación $\downarrow / e n$ forma de ideología $\downarrow$
A:
[claro $\downarrow$ ]
[claro $\downarrow$ ]
[eh $\downarrow$ eh $\downarrow$ sé $\downarrow]$
A: ya bacán $\uparrow$ ya entonces $\downarrow$ sería $\downarrow$ (RISAS) partamos con (( ))

Uma leitura desatenta da amostra anterior nos levaria a depreender que as intervenções de $\mathrm{C}, \mathrm{A}$ e $\mathrm{B}$, que se sobrepõem, sinalizam a atividade da imagem de cooperação, quando as falantes se auxiliam, repetem-se e respaldam umas as outras na formulação discursiva. Porém, o assalto de turno, sem a ocorrência de um lugar relevante; de A - "[ah sí (())] §el electorado see $\rightarrow$ comporta o mueve =se mueven $\downarrow "$ - unido a seu comportamento não verbal, repetidos movimentos de cabeça para cima e para baixo, olhar direcionado aos cadernos sinalizando que sua atenção não está totalmente voltada à falante $C$, reforçam, neste caso, a atividade da imagem de excelência por parte de A. A falante A sente a necessidade de projetar as suas boas qualidades, o seu conhecimento e sobressair indicando que já sabe do que $C$ está falando, a interrompe e termina de desenvolver o tópico conversacional juntamente com $\mathrm{B}$. A falante B faz o mesmo ao encontrar um lugar relevante para a mudança de turno - "de cómo- [de acuerdo] a como [ellos/] entregan $\downarrow /$ esta [infor]mación $\downarrow / e n$ forma de ideología $\downarrow$ " -, mas enquanto, fala, a falante A produz constantes 


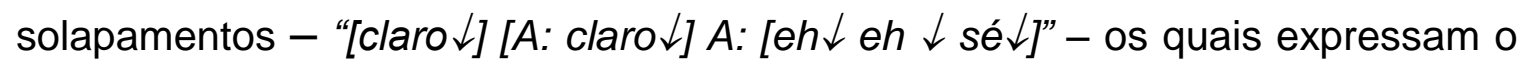
acordo com $B$ e reforçam o seu conhecimento sobre a matéria. Em seguida, A encerra o tópico e propõe outro - "ya bacán $\uparrow$ ya entonces $\downarrow$ sería $\downarrow$ (Risas) partamos con (( ))" -, provavelmente porque julga que é um tópico que não precisa de discussão ou mais comentários.

Em todo o evento comunicativo gravado entre estas três falantes, notadamente observamos que a falante $A$ parece projetar uma valorização da ordem e respeito à mesma, porque ela assume o papel de começar e encerrar os tópicos conversacionais relacionados aos temas de estudo, como nos exemplos abaixo:

(10)

(RISAS)

A: ya / cuatro $\downarrow$ /el desplazamiento de los límites de la política $\downarrow$ / ya esa es fácil $\downarrow / / e n$ la simple estaban los espacios $\downarrow$ / era el estado nación y los actores sociológicos eran los políticos profesionales $\downarrow /$ y en la reflexiva $\rightarrow$ / een los espacio era la globalización $\downarrow /$ y los actores son los policy makers y los outsiders $\downarrow$

C: el estado

(11)

$=$ política $\downarrow$ / y desincronía de los tiempos $\downarrow$ / y ahí la volá $\downarrow /$ repitamos como loro los seis po $\downarrow /$ los encabezados $\downarrow$

C: la sociedad moderna $\rightarrow$

A: ya uno uno a uno $\downarrow$ / ya dale $\downarrow$

Destacamos aqui somente duas amostras do comportamento comunicativo de $A$, que é recorrente em toda a gravação, porque os atos exortativos serão estudados em outra seção nesta pesquisa. A falante em (10), em um ato exortativo - "ya / cuatro $\downarrow$ " - realiza uma operação enunciativa que mostra o controle da comunicação. O marcador metadiscursivo e regulador "ya" localizado no início de suas intervenções, corta o discurso da ouvinte, para prosseguir com outro tópico (Andrade, 2006). De igual maneira em (11), o uso do imperativo - "repitamos como loro los seis po $\downarrow /$ los encabezados $\downarrow$ " - e a presença do marcador modalizador "po", intensifica a força ilocutória da atitude 
da falante, reforçam a imagem de hierarquia e de ordem, ao solitar a todas que repitam, uma de cada vez, frases memorizadas relacionadas à teoria em estudo.

Verificamos também, a seguir, a heterorrepetição envolvida na expressão do acordo entre as falantes $A$ e $B$ :

(12)

A: por eso yo pondría lo del conocimiento imperfecto e ignorancia $\rightarrow$ racional porque es máas $\rightarrow / /$ no sé $\downarrow$ 3 "

A: ya qué hacemos / Legner?

B: Legner y después $\downarrow /$ las tarjetitas $\downarrow$

C: (())

A: ya $\downarrow$

C: poder/?política?

A: no $\downarrow /$ poder noo $\downarrow /$ no $\downarrow$

B: la weá del estado $\downarrow$

A: la weá del estado $\downarrow / /$ no yo poder me lo sabíía// ay/ qué buenas las preguntas $\S$ (risas)

C:

$\S(())$

C: oye iba a buscar la guía hecha/ se me olvidó $\downarrow$ / oye que hace calor aquí

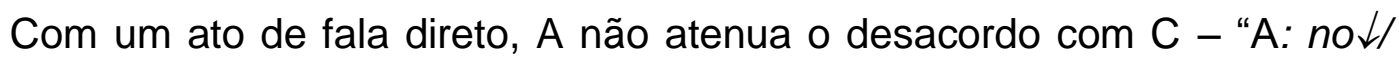
poder noo $\downarrow /$ no $\downarrow$ " - e em seguida recebe o apoio de B que entrega o enunciado esperado - "la weá41 del estadol" -, ao que A com a repetição do enunciado de $B$ também reforça a imagem de cooperação e a cortesia construtiva.

No próximo fragmento, a heterorrepetição entre $C$ e $A$ também sinaliza a aceitação e a expressão do acordo com a falante, no entanto, intensifica-se, ao mesmo tempo, o desacordo com B:

(13)

B: ya a ver miren $\downarrow$ (actutidunaria) del ámbito persona y su entorno $\downarrow$ / donde reconozcan la historia de los actores $\downarrow$ la respeten y le valoren los simbolismos de este $\downarrow$ memorias de Paine $\downarrow / /$ o los detenidos desaparecidos del lugar $\downarrow$ reconocer la historia y esa cuestión una wea que a nadie le importa po

C: ¿cómo que a nadie le importa? $\S$

A:

$\S$ ¿cómo que a nadie le importa?

\footnotetext{
${ }^{41} \mathrm{Na}$ linguagem coloquial juvenil chilena, a palavra "weá” (huevada) se assemelha a "cosa”, “cuestión”, ou "tontería", dependendo do contexto.
} 
B: a nadie le importa tú creih que a los cabros $\operatorname{chicos}^{42}$ les va a importar esto / a NOSOTROH NOH importa
A: (( ))
B: que te imPORTE
C: para ser la ti $\downarrow$ si hoy dia estaba escuchando esa wea así como con la colonia dignidad $\downarrow$
/ voy a meterle una pregunta de esas a los chiquillos $\downarrow$ / desarrolle en la prueba $\downarrow$ / he dicho $\downarrow$ / quiero que me digan por qué de importante tiene estudiar la colonia $\downarrow$
$((\ldots))$
A: ya $\uparrow$ / bueno $\downarrow$ / ahí tenemos el ejemplo ya po / mira deja explicarte entonces $\downarrow$ / nosotras part-primero partimos como de la idea de la activida' $\uparrow \S=$
C: $\S$ yaa $\uparrow$

Nesse evento comunicativo, temos participantes que se encontram reunidas em um ambiente informal, possivelmente uma sala de estudos, rodeadas por um entorno bastante ruidoso. São três alunas do curso de licenciatura em História e, no momento da gravação, é desenvolvida, em grupo, a preparação de uma aula para o ensino médio. Vemos no fragmento anterior a expressão direta do desacordo de $\mathrm{A}$ e $\mathrm{C}$ ante o enunciado de $\mathrm{B}$, em que a heterorrepetição da falante $A$ adiciona força argumentativa ao que é dito.

Em outro encontro de estudos chileno, três estudantes universitários, um jovem e duas jovens, do curso de tradução, estabelecem passos para o desenvolvimento de um trabalho de investigação científica. Curioso foi notar nesse evento que os fenômenos de heterorrepetição, em sua maioria, participaram da manifestação do desacordo, o que não encontramos no corpus brasileiro. Pois, do total de encontros de estudos do corpus chileno, a heterropetição somente ocorreu na voz daquele que não detinha a voz instrutiva 34 vezes, ou seja, em $20 \%$ do total de casos de heterropetições, com o fim de apoiar ou reforçar o que seu interlocutor disse.

$O$ falante $B$, neste fragmento, reforça a imagem de hierarquia e ordem e domina a apresentação ou o encerramento de tópicos conversacionais durante este evento comunicativo. $\mathrm{Na}$ amostra seguinte, expressa a não aceitação do conteúdo do turno da falante $A$, que é quem detém a voz instrutiva na maior parte do tempo neste encontro.

\footnotetext{
${ }^{42}$ Muito freqüente no Chile, "cabros chicos" pode referir-se informalmente a crianças ou adolescentes.
} 
(14)

A: coloca estudioo - tipo de estudio de investigación $\downarrow$ /// sí era esto te decía / tipos de estudio dee / no sé qué decía / investigación (())

B: ¿ese eh el primero?

A: $\mathrm{mm}(()) /$ cualquiera de eso $\uparrow$

$\mathrm{B}:{ }^{\circ}(())^{\circ}$

A: que terrible / no $\uparrow$

$5 "$

B: (()) / eem

A: histórica descriptiva y experimental / (())

B: la histórica no eh po $\downarrow$

A: (()) / ya / no eh histórica $\downarrow$

$\mathrm{B}$ : ya (()) / según se mencionó / trabaja sobre realidades de hechos $(())$

A: (()) /// eh que es inevitable porque está / e / te va a mostrar puras cosas (()) cuantitativas Pancho $\uparrow$

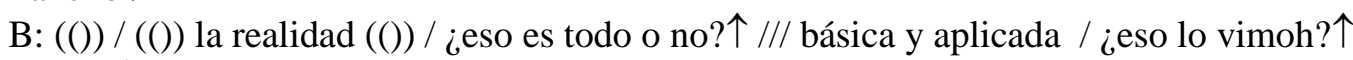

A: $\mathrm{mm} \downarrow$

2.1.1.1.4. Apresentação dos resultados: a heterorrepetição e as estratégias de cortesia envolvidas na construção da imagem dos participantes da interação brasileira e chilena

No material de análise brasileiro e chileno, a heterorrepetição esteve envolvida na atividade de co-construção do enunciado, valorizando a imagem autocêntrica e alocêntrica de cooperação quando os interactantes se auxiliam, repetem-se e respaldam uns aos outros na formulação discursiva. Muitas vezes, o falante que realiza a heterorrepetição expressa o acordo com o interlocutor, reforçando a imagem de hierarquia e excelência de quem detém a voz instrutiva. Podendo valorizar assim a cortesia de solidariedade. Contudo, no corpus chileno tivemos $20 \%$ do total de 91 casos de heterropetições com o fim de apoiar ou reforçar o que seu interlocutor que detém a voz instrutiva disse, e no brasileiro, $51 \%$, de um total de 165 casos.

Nas interações chilenas, contudo, a co-construção do enunciado pode manifestar também uma atividade de imagem autocêntrica quando um interlocutor sente a necessidade de projetar as suas boas qualidades, o seu conhecimento e sobressair, indicando que sabe do tema que está sendo tratado. 
Dessa maneira, pode co-construir com o outro um tópico conversacional, repetindo o que este diz e agregando mais informações, projetando assim a sua imagem de excelência.

No corpus brasileiro, a heterorrepetição participa da manutenção do contato social, representando uma estratégia de proteção da imagem daquele que expressa menos conhecimento, como tentativa de mostrar-se cooperativo e frisar que a sua atenção está voltada a seu interlocutor ou que a mensagem foi entendida. Dessa atitude, portanto, é possível inferir-se a expressão do acordo e conformidade com o que o falante diz e o reforço da imagem de cordialidade.

A expressão do desacordo foi encontrada no corpus de Santiago com certa frequência ligada à heterorrepetição, em que o interactante reforça a sua imagem de hierarquia e ordem e domina a apresentação ou o encerramento de tópicos conversacionais durante um evento comunicativo. Pode, portanto, expressar a não aceitação do conteúdo do turno do interlocutor, participando da orientação argumentativa.

A seguir, sintetizam-se estes resultados em quadros que apresentam os mecanismos de gestão de imagens nos encontros de estudo no âmbito acadêmico observados no material de análise. 
QUADRO 3 - HETERORREPETIÇÃO E ESTRATÉGIAS DE CORTESIA ENVOLVIDAS NA CONSTRUÇ̃̃O DA IMAGEM DOS PARTICIPANTES DE GRUPOS DE ESTUDOS ACADÊMICOS EM SÃO PAULO (BRASIL)

\begin{tabular}{|c|c|c|}
\hline $\begin{array}{c}\text { FENÔMENO LINGUÍSTICO EM } \\
\text { ATOS ASSERTIVOS }\end{array}$ & $\begin{array}{c}\text { PAPÉIS PRAGMÁTICOS } \\
\text { Em geral, podem manifestar-se juntamente com a } \\
\text { heterorrepetição: }\end{array}$ & EXEMPLOS \\
\hline \multirow[t]{2}{*}{$\begin{array}{l}\text { Heterorrepetição: } \\
\text { Transmite cortesia, reforçando imagens } \\
\text { auto- e alocêntricas. }\end{array}$} & $\begin{array}{l}\text { 1) Co-construção do enunciado: atividade de imagem } \\
\text { auto- e alocêntrica: a heterorrepetição sinaliza a } \\
\text { atividade da imagem autocêntrica e alocêntrica de } \\
\text { cooperação, quando os interactantes se auxiliam, } \\
\text { repetem-se e respaldam uns aos outros na formulação } \\
\text { discursiva. O falante muitas vezes expressa o acordo com } \\
\text { o interlocutor, reforçando a imagem de hierarquia e } \\
\text { excelência do outro. Pode-se valorizar assim a cortesia de } \\
\text { solidariedade. }\end{array}$ & $\begin{array}{l}\text { (...) } \\
\text { B:é por isso/ é um crime de ódio/ isso não tá claro/ } \\
\text { então/ isso não estando claro pra sociedade/ a imprensa } \\
\text { nem questiona na hora de fazer a cobertura } \\
\text { A: é/ não tá claro// acho que a opressão acaba se aa se } \\
\text { infiltrando nos dois/ ela tá na imprensa e também tá na } \\
\text { polícia da polícia afirmar isso sem menor } \\
\text { questionamento/ quer dizer/ não é nem que aaa talvez } \\
\text { nesse caso a polícia esteja realmente escondendo/ a } \\
\text { gente não sabe o que aconteceu porque teve toda essa } \\
\text { coisa da da mãe negaaa numa situação super §confusa } \\
\text { (BRAAB28/01/2014) }\end{array}$ \\
\hline & $\begin{array}{l}\text { 2) Contato social: a heterropetição pode representar uma } \\
\text { estratégia de proteção da imagem daquele que expressa } \\
\text { menos conhecimento, como tentativa de mostrar-se } \\
\text { cooperativo e frisar que a sua atenção está voltada a seu } \\
\text { interlocutor ou que a mensagem foi entendida, marcando } \\
\text { o contato social. Dessa atitude é possível inferir-se a } \\
\text { expressão do acordo e conformidade com o que o falante } \\
\text { diz e o reforço da imagem de cordialidade. }\end{array}$ & $\begin{array}{l}\text { A: quer dizer aa ele teve o sentimento e como se o } \\
\text { sentimento nas pessoas/ não fizesse parte de um nn } \\
\text { conjunto né? um aprendizado emocional/ que que tem } \\
\text { a ver com essa cultura machista// então/e e agora/ mas } \\
\text { é louco isso porque como a gente consegue pensar aa/ } \\
\text { sei lá/ no dia a dia do repórter/ que ele vai até na na } \\
\text { delegacia aparece um caso desses/ e a cobrança é pra } \\
\text { que ele chegue na redação com o caso né? e falar [o } \\
\text { que aconteceu] } \\
\text { B: [o que aconteceu] } \\
\text { A: o que foi o que não foi e pronto// né? / e o próprio } \\
\text { dia a dia do jornalismo acaba impedindo né? um nn / } \\
\text { (...) } \\
\text { (BRAAB28/01/2014) }\end{array}$ \\
\hline
\end{tabular}


QUADRO 4 - HETERORREPETIÇÃO E ESTRATÉGIAS DE CORTESIA ENVOLVIDAS NA CONSTRUÇÃO DA IMAGEM DOS PARTICIPANTES DE GRUPOS DE ESTUDOS ACADÊMICOS EM SANTIAGO DO CHILE

\begin{tabular}{|c|c|c|}
\hline $\begin{array}{c}\text { FENÔMENO LINGUÍSTICO EM } \\
\text { ATOS ASSERTIVOS }\end{array}$ & $\begin{array}{c}\text { PAPÉIS PRAGMÁTICOS } \\
\text { Em geral, podem manifestar-se juntamente com a } \\
\text { heterorrepetição: }\end{array}$ & EXEMPLOS \\
\hline \multirow[t]{2}{*}{$\begin{array}{l}\text { Heterorrepetição } \\
\text { Participa de atividades autocêntricas } \\
\text { e pode ou não transmitir cortesia. }\end{array}$} & $\begin{array}{l}\text { 1) Co-construção do enunciado: atividade de } \\
\text { imagem auto- e alocêntrica: a heterorrepetição } \\
\text { sinaliza a atividade da imagem autocêntrica e } \\
\text { alocêntrica de cooperação, quando os interactantes } \\
\text { se auxiliam, repetem-se e respaldam uns aos outros } \\
\text { na formulação discursiva. O falante muitas vezes } \\
\text { expressa o acordo com o interlocutor, reforçando a } \\
\text { imagem de hierarquia e excelência do outro. Pode- } \\
\text { se valorizar assim a cortesia de solidariedade. }\end{array}$ & $\begin{array}{l}\text { A: ya qué hacemos / Legner? } \\
\text { B: Legner y después } \downarrow / \text { las tarjetitas } \downarrow \\
\text { C: (( )) } \\
\text { A: ya } \downarrow \\
\text { C: poder/?política? } \\
\text { A: no } \downarrow / \text { poder noo } \downarrow / \text { no } \downarrow \\
\text { B: la weá del estado } \downarrow \\
\text { A: la weá del estado } \downarrow / / \text { no yo poder me lo sabíía// ay/ qué } \\
\text { buenas las preguntas } \S \text { (risas) } \\
\text { C: } \quad \S(()) \\
\text { C: oye iba a buscar la guía hecha/ se me olvidó } \downarrow / \text { oye que hace } \\
\text { calor aquí }\end{array}$ \\
\hline & $\begin{array}{l}\text { 2) Co-construção do enunciado: atividade de } \\
\text { imagem autocêntrica: quando um interlocutor } \\
\text { sente a necessidade de projetar as suas boas } \\
\text { qualidades, o seu conhecimento e sobressair, } \\
\text { indicando que sabe do tema que está sendo tratado, } \\
\text { pode co-construir com o outro um tópico } \\
\text { conversacional, repetindo o que este diz e } \\
\text { agregando mais informações. Desempenha, } \\
\text { portanto uma atividade autocêntrica na gestão das } \\
\text { imagens, projetando a sua imagem de excelência. }\end{array}$ & $\begin{array}{l}\text { C: claro } \downarrow \text { es que lo que pasa es que estos tres modelos son-es la } \\
\text { relación asimétrica } \downarrow \text { lo que estánnn dibujandoo o graficando es } \\
\text { la relación } \downarrow / \text { claro dice que la relación entre electorado y-o } \\
\text { partídoh políticoh o actoreh políticoh ES asimétrica } \uparrow / \text { ipor } \\
\text { qué? } \uparrow \text { porque el po-los partidos políticoh o actoreh políticoh } \\
\text { tienen el poder } \downarrow \text { / y tie- y ha-hacen que la-el electorado se } \\
\text { mueva [de acuerdo] a como ellos } \S \\
\text { A: } \quad \text { [ah sí (( ))] §el electorado } \\
\text { comporta o mueve }=\text { se mueven } \downarrow \\
\text { B: de cómo- [de acuerdo] a como [ellos/] entregan } \downarrow \text { / } \\
\text { esta [infor]mación } \downarrow \text { /en forma de ideología } \downarrow\end{array}$ \\
\hline
\end{tabular}




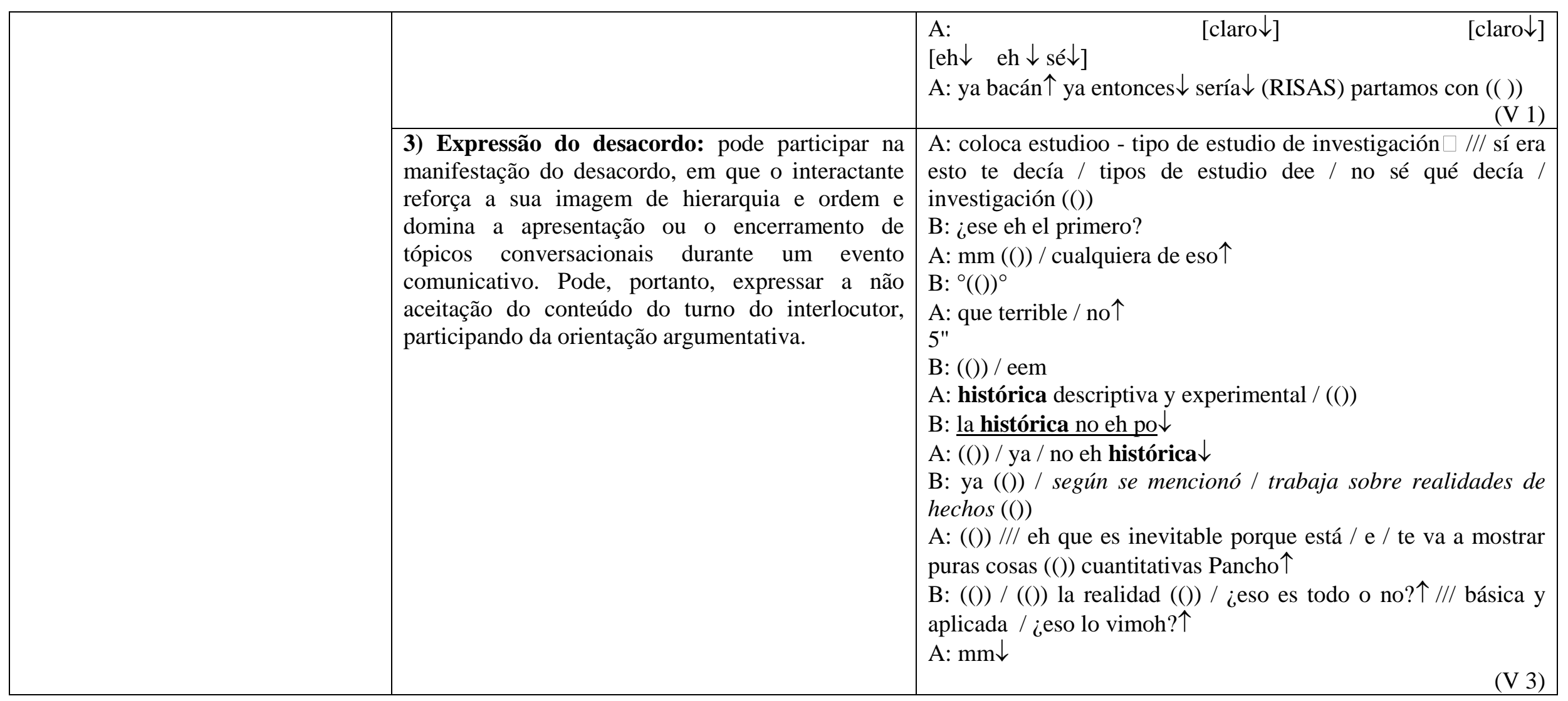




\subsubsection{Atos diretivos}

Os atos diretivos pressupõem uma carga potencial de ameaça à imagem de autonomia do interlocutor, pois o falante realiza um ato diretivo com o fim de influir no comportamento intencional do ouvinte, a fim de que este realize a ação presente no conteúdo proposicional do enunciado.

Para o presente estudo, nos interessa analisar o trabalho de imagens como também a cortesia estratégica envolvida nos pedidos, e examinamos nesta seção a atenuação da força ilocutória principalmente no ato de fala de pedir, que constitui um ato que supõe uma intrusão no território do ouvinte, limitando a sua liberdade de ação e ameaçando a face de autonomia.

Vamos começar a análise dos atos diretivos nesta seção apresentando amostras do corpus chileno, embora nas seções anteriores tenhamos iniciado com análise com o corpus brasileiro, simplesmente porque esta ordem de apresentação é aleatória.

Em todo o corpus chileno, encontramos graus de intensidade diferentes na expressão da intenção de que o ouvinte aja de uma determinada forma. $\mathrm{Na}$ seguinte amostra de interação, podemos observar que o falante $D$ não faz parte do grupo de estudos composto por três alunas que conversam sentadas num gramado ao ar livre. Ele se aproxima e pede-Ihes um isqueiro:

(1)

B: emmm/ ya $\downarrow /$ y el auge de la cultura audiovisual $\downarrow$

A: auge de la cultura audiovisual $\downarrow$ / en la simple $\rightarrow$

D: oye $\downarrow$ / hola / me podí prestar fuego porfa

A: acá está $\downarrow$

A: en la simple los (()) resultaban fundamentales para la construcción del orden republicano y de la política $\downarrow / /$ los liberales contractualistas planteaban que los medios debían ser autónomos de los poderes estatales $\downarrow$ (...)

Devido à distância social entre o jovem e as alunas, percebe-se aqui uso convencional de um pedido indireto - "me podí prestar fuego porfa", marcado também pelo tom informal do voseo chileno - "podî" -, que reforça a afiliação neste contexto, como a presença do modificador verbal e modalizador frequente 
na linguagem juvenil chilena "porfa" (por favor). Depois de usar o isqueiro, não percebemos nenhum turno de agradecimento.

Por um lado, o ato ilocutório de pedir poderia produzir um efeito negativo sobre a relação que se criou entre os interlocutores, D e as demais estudantes, se $D$ não tivesse usado uma fórmula esperada e adequada à situação, o que se pode medir de acordo uma escala de custo-benefício (Leech, 1983), segundo a qual o pedido constitui um ato de fala não cortês, uma vez que implica algum custo para o ouvinte e certo benefício para o falante, como mencionamos anteriormente. Por outro, a ausência do agradecimento pode dar-se devido à avaliação de que não haveria relevante desequilíbrio social numa situação comunicativa em que a imposição do ato não é proeminente e a informalidade é alta.

A amostra seguinte faz parte de uma gravação de um encontro entre estudantes universitárias chilenas do curso de tradução espanhol-português, em que participam cincos alunas, num pátio da faculdade. $\mathrm{O}$ ambiente se mostra bastante informal e a tarefa que desempenham é realizar uma produção escrita, criar uma bula de um remédio imaginário em língua portuguesa, com a tarefa de usar o léxico adequado.

Durante o encontro, a falante $B$ é quem dirige a reunião e também quem redige o texto a partir das contribuições das demais. Ao criar por escrito a lista de conteúdos, inventaram que um dos componentes do medicamento imaginário seria cartilagem de "tiburón", mas ao não encontrar a tradução ao português de "tiburón" em uma primeira busca no Google, a falante C, que era quem procurava a palavra na internet, sugeriu que então escrevessem "cartilagem de baleia", ideia que foi rechaçada pelas demais:

(2)

C: ((oye)) ¿alguien sabe como decir ballena? / pa'que pongamos ballenah $\rightarrow$

B: ballena ballena $\downarrow /$ ¿de ballena? $\uparrow$

A: noo cómo se te ocurre

B: de oorca / calla $\downarrow$

C: ¿orca?

D: de orca (RISAS)

B: noo ya dee- de tiburón no máh pu

C: pero ¿por qué no sale tiburón? (ENTRE RISAS)

D: ¿no sale tiburón? /

C: (es)pérate $\downarrow$ 


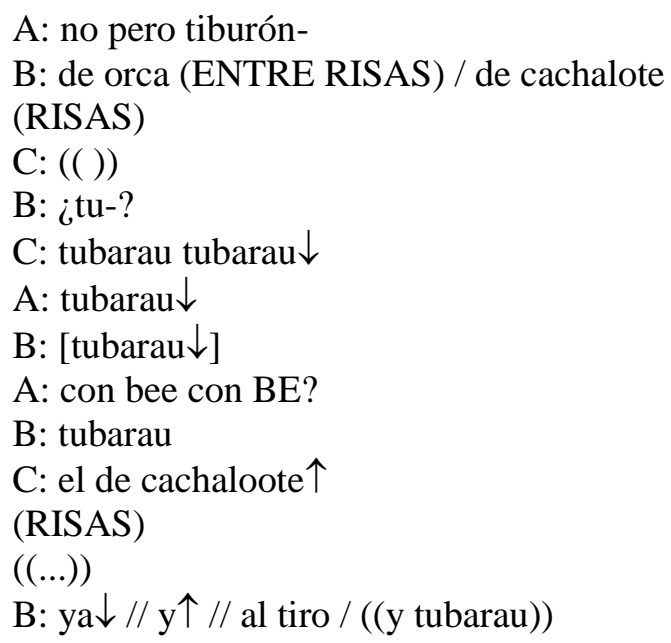

A aluna $B$, que é quem mais controla o desenvolvimento dos tópicos em todo o encontro, usufrui da proteção de sua imagem de hierarquia e ordem e, inclusive, emprega a ironia no enunciando "de oorca / calla $\downarrow$ " apoiando a sua decisão de manter a ideia inicial, a de escrever "cartilagem de tubarão". A falante A, foi a primeira a expressar uma crítica - "noo cómo se te ocurre" - após o questionamento de B - "¿de ballena? $\uparrow^{-}-_{-}, \mathrm{e}$, no vídeo, vemos que este turno irônico de B - "de oorca / calla $\downarrow$ " -, que debocha da opinião de C, é direcionado a $A$, segundo seu olhar, excluindo a $C$, de certa maneira. Deste exato momento foi capturada na imagem abaixo:

Imagem 3 - Pedido e ironia - V4

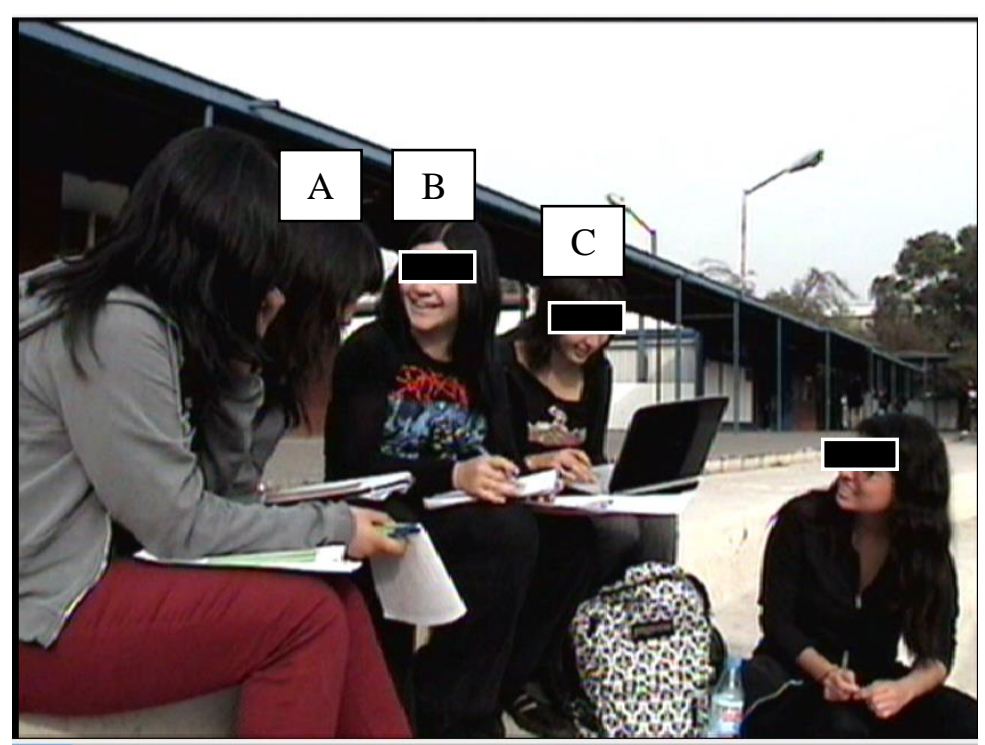


A e B apresentam assim uma crítica certamente maliciosa com base no que consideram um engano de $C$ e então $B$ começa a mencionar espécies de baleias, a partir do exagero, e a rir da proposta de C - "de orca (ENTRE RISAS) / de cachalote". Diverte-se e diverte as demais.

Por um lado, a falante $B$, apoiada por $A$, ameaça a face de excelência de $C$, mostrando a sua atitude negativa com relação ao seu enunciado (Reyes, 1998: 50). A ironia aqui transmite a expressão implícita das atitudes de $B$ e cria certa impressão nas demais ouvintes sobre a imagem de C. Por outro lado, o fato de a ironia produzir um efeito de burla, humor e divertimento ao grupo, reforça também a face positivamente de sua autora.

Além disso, o pedido "calla", direcionado à falante $\mathrm{C}$, é um ato diretivo que se interpreta como ameaçador para a sua imagem, porém, ao mesmo tempo, "calla" se trata de um pedido convencional em imperativo em situações coloquiais e juvenis ao expressar desacordo no Chile. Vemos que $C$ não $o$ interpreta como uma ameaça neste contexto, pois provavelmente a relação de proximidade e o traço vivencial de informalidade permitem que não seja interpretado como descortês. Inclusive as risadas gerais podem agir também nesta ocasião como mecanismo de familiaridade (Bravo, 1996). Semelhantemente, a intervenção de C em "(es)pérate $\downarrow$ " produz outro pedido convencional em imperativo muito frequente nas conversações coloquiais juvenis chilenas, encontrado muitas vezes no corpus:

(3)

D: van a tener que leer eso despuéh // pero espera / ese texto también existe la otra para' del profe de que existen dos corrieenteh o ¿de qué está hablando? $\uparrow$

A: noo si esto

C: $(())$ la $(())$

(V10)

Na sequência anterior há cinco estudantes de jornalismo chilenos, entre os quais a falante $B$ é quem tem a imagem de ordem e hierarquia fortalecida, posto que domina mais turnos e controla a mudança de tópicos durante toda a gravação. D emprega o pedido convencional em imperativo "espera" que, neste contexto, introduz a unidade discursiva sobre outro tópico conversacional. 
Em um encontro com fins de estudo entre estudantes universitários, sabemos que na gestão interrelacional desempenha um papel importante o fato de demonstrar conhecimento, que se vincula à cultura, saber próprio e habilidade de reflexão. O conhecimento ou o fato de conduzir uma reunião de maneira organizada determinam papéis hierárquicos entre os interlocutores. Poderia-se presumir, portanto, que aquele que detém a voz instrutiva entre os demais poderia realizar pedidos mediante poucos recursos modalizadores ou de atenuação, segundo sua posição de poder. No entanto, há de relevar-se aqui que a cortesia linguística abriga uma série de estratégias que regulam as relações humanas no âmbito da comunicação, no que concerne à manutenção do equilíbrio de uma atividade comunicativa oral e é o que temos em (4):

(4)

A: AH / eso de- que tenía que ir en cursiva $\downarrow$

C: necesito ir a buscar loh ejemploh a la biblioteca (( ))

$(\mathrm{V} 11.2)$

Esse fragmento faz parte da transcrição da filmagem de uma reunião entre estudantes do curso universitário de tradução, em que participam um aluno, o falante $\mathrm{C}$, e duas alunas, $\mathrm{A}$ e $\mathrm{B}$. Logo após esta breve sequência, o aluno se levanta e sai, de forma que temos somente as jovens $A$ e $B$, numa sala de aula, e $B$ redigindo um trabalho em um laptop. Observamos na filmagem que a falante $\mathrm{A}$, desde a saída do colega, detém a voz instrutiva e conduz a redação e revisão do texto, de que se ocupa $B$ em seu computador. Após enunciar " $A H$ / eso de- que tenía que ir en cursiva $\downarrow$ ", apontando para a tela do computador de $B$, esta parece corrigir algo no arquivo que produzem. Assim, embora não se realize um ato de pedir, infere-se como tal; o enunciado de $A$, além disso, tem mais a forma de discurso indireto - "tenía que ir" - em que o pretérito imperfeto se assemelha a um dêitico que aponta a um momento de enunciação anterior. $A$ falante $A$, portanto, não realiza 0 pedido e evita assim ameaçar a face da ouvinte, embora seja ela, a falante $A$, quem detenha uma posição hierárquica mais destacada nesta sequência.

Levamos em consideração que a cortesia é um fenômeno social, de modo que, havendo somente dois participantes, a preocupação com o trabalho de imagens pode intensificar-se. 
Em outros momentos desta interação, há casos em que também não se formula um pedido direto, como em (5):

(5)

A: [ $i$ y eso? ¿arriba?] /// donde dice / eso (( )) puro $\uparrow$ / podríamooh pegarloh aquí mismo / e- es anteh del híbrido $\rightarrow$

B: aah ya $\downarrow / / /$ y esto lo copié tal cual como estaba (( )) en el otro liibro por eso (quedó así) $7^{\prime 43}$

B: esto (( ))

$14 " 44$

A: ¿por quée (( )) /// ee /// a su vez?

B: (no puede subdividiirSE / en)

(RISAS)

A: no mejor no si está muy bien (( )) para que le pusierai / se puede subdividirse

$(\mathrm{V} 11.2)$

Observamos que "podríamooh pegarloh aquí mismo" se trata de uma orientação de $\mathrm{A}$ a $\mathrm{B}$, que vai modificando um texto em seu computador. De acordo com Haverkate (1994: 31), verifica-se aqui um ato indireto com uma estratégia pseudoinclusiva; a falante A emprega a primeira pessoa do plural no lugar da segunda pessoa do singular neste contexto, o que tem valor decisivo, na relação social assimétrica entre os interlocutores, produz o efeito de solidariedade com a ouvinte e, neste caso, torna menos nítida a distância que as separa, podendo reforçar a ideia de que realizam um trabalho compartilhado, que é o que realmente acontece. Vemos que após "podríamooh pegarloh aquí mismo", a ouvinte acata a ideia com "aah ya $\downarrow$ ".

A hierarquia se manifesta em seguida, nesse fragmento ainda, quando $B$ busca a aprovação, de maneira não verbal, aponta para o texto que preparou e, logo, $A$ e $B$ refletem sobre a adequação de expressões na produção escrita. Mas antes, dotada de sua posição hierárquica, a falante $A$ aprova o trabalho de $B$ com "si está muy bien", empregando inclusive neste momento um sorriso que também favorece a afiliação.

Sabemos que, em geral, uma petição é um ato ilocutorio por meio do qual um falante comunica a um ouvinte que quer que este realize um ato que consecutirá um benefício ao falante. Entretanto, na situação dos encontros de estudos, em que, muitas vezes, são desenvolvidos trabalhos grupais, entende-

\footnotetext{
${ }^{43}$ Leitura silenciosa.

${ }^{44}$ Leitura silenciosa.
} 
se que não somente aquele que enuncia a petição será beneficiado, mas, em muitos casos, os demais participantes da equipe também, quando se trata da realização de um "bem" verbal relativo à evolução da atividade acadêmica que realizam e à transmissão de conhecimentos.

Cremos que a petição revela também uma dupla função, a desiderativa e a impositiva. Por um lado, de acordo com Bach e Harnish (1979), manifesta a intenção ou o desejo do falante de que o ouvinte considere o seu enunciado como um motivo para realizar o conteúdo proposicional do ato. Por outro, conforme Leech (1983) e Haverkate (1994), o cumprimento de uma petição pressupõe um esforço e certo custo para o ouvinte, como mencionamos.

Certamente, através do ato de pedir, o falante busca exercer influência sobre o ouvinte, e, por esta perspectiva, verificamos que no corpus chileno, em quase todas as gravações, ocorreu o ato de petição pertinente à manutenção da ordem da atividade que os estudantes desenvolviam, ou seja, de 14 eventos gravados somente dois (14,28\%) não possuem sequências conversacionais em que os estudantes discutem questões relativas à ordem do desenvolvimento dos trabalhos e atividades acadêmicas.

Assim, no fragmento a seguir, cuja parte foi analisada antes na seção de autorrepetição, interagem cinco estudantes de jornalismo, quatro mulheres e um homem, que antes do início do período de estudos em si, discutem se a porcentagem de presença dos alunos de determinada disciplina é de sessenta ou setenta por cento, além de outras questões relativas à lista de presença:

(6)

A: (¿pero no que esto eh lo que pide la escuela?)

B: pero eso eh lo que dijo en el programa $\uparrow$

A: sí po / y dijoo / y dijo / setenta por ciento de $(())$

C: [igual el profesor dijo $(())]$

B: [pero no podría $(())$ / no podría haceerlo porque nosotroh / porque la mayoría tiene problemaah dee asistencia

C: [ssíí se puede]

D: pero (Cote si) el diijo / la primera clase / que era setenta por ciento (())

A: [no po si / eso eso lo aclaró despuéh // eso eso] lo aclaró dijo // no si / setenta por ciento es lo que pide la escuela / (()) no voy a estar pidiendo / y yo le dije pero profe / usted dijo sesenta $\downarrow$ / y El

?: [y] dijo // no $\uparrow /$ si eso eh lo que voy a pedir yo / y punto $\downarrow$

B: a ya bacán $\uparrow /$ osea yo creo que cuando (()) el próximo semestre $\uparrow$ / osea / (())

C: [lo podí hacer (()) ]/ aparte no creo que los cursoh (())

B: cómo que no tiene presente / ese día que (()) la listaa / yo me tenía que anotar de la últimah / y

como que quedaba un espacio me anotée entre medio como pa' / no pareciera que (())

C: yo igual hice eso $\downarrow$ / así como que / ay me anoté entre medioo / me anoté chiquitito $\downarrow$

?: $[(())]$ 


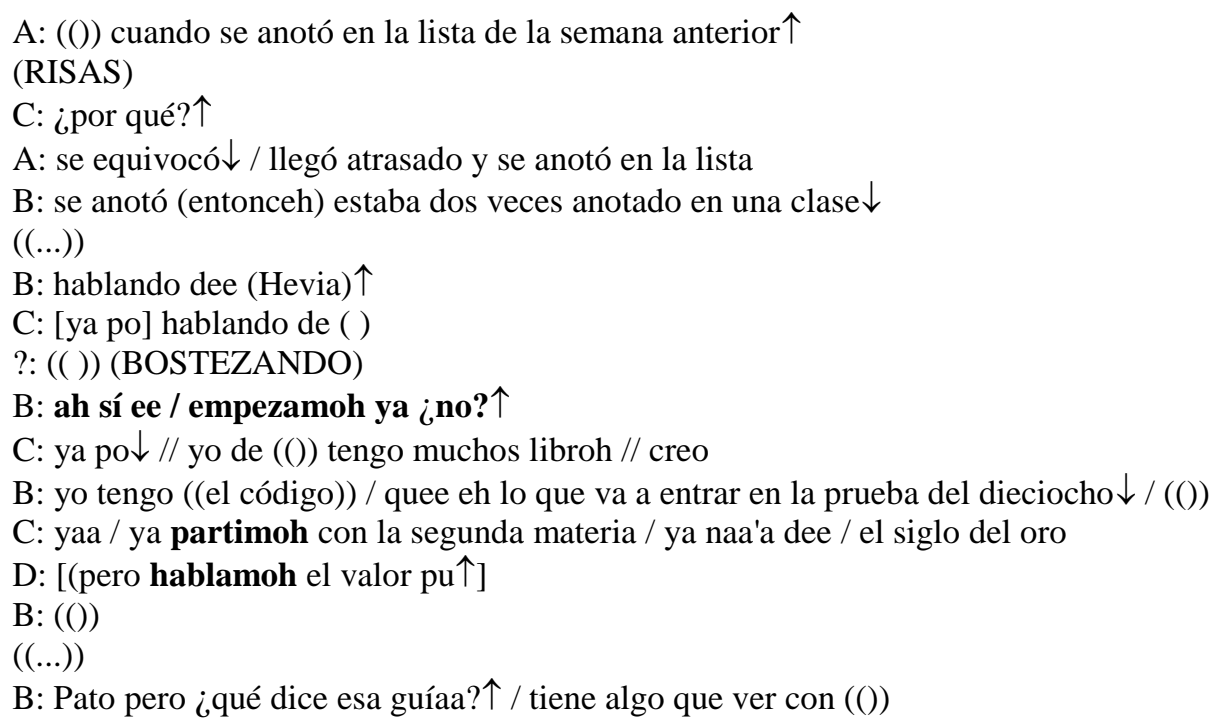

Estas trocas conversacionais referem-se aos primeiros momentos da gravação e também do episódio conversacional, de forma que se supõe que ainda, precisamente, não tinham se estabelecido hierarquicamente as relações sociais alusivas ao aluno que domina mais turnos, devido à sua demonstração de conhecimento e faculdade de organizar a reunião. Nesse sentido, o falante $B$ propõe que comecem a reunião efetivamente - "empezamoh ya ¿no?”-, manifestando cortesia construtiva, através do uso de um verbo no presente do indicativo no lugar de uma forma verbal imperativa, o que também ocorre nos turnos seguintes das falantes C e D - "yaa / ya partimoh con la segunda materia

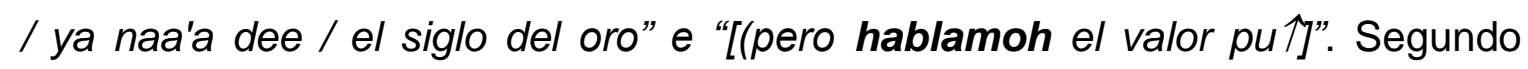
Crystal (1985), a seleção do modo imperativo, e de outros, encontra-se associada à atitude do falante como também à modalização do conteúdo proposicional de um enunciado, porque neste caso observamos a presença de verbos em presente do indicativo, que produzem atos indiretos.

O marcador de contato “¿no?”, neste caso, na intervenção de B, embora apele aos ouvintes, solicitando sua confirmação, atenua a imposição do falante à medida que fortalece a imagem de cooperação dos demais na tomada desta decisão.

Após esse ato, a falante C aceita a proposta em seguida, mediante 0 modalizador "ya po", em que a partícula "ya" marca o início de sua intervenção, revelando o seu caráter reativo e agindo como veículo para expressar o acordo 
que foi intensificado por "po (pues)", que expressa apoio ou reforço ao que foi dito (Andrade, 2010).

Recordemos que, no contexto social chileno, manifesta-se um conteúdo de imagem que formulamos como imagem de ordem, pela qual o interactante sente a necessidade de projetar uma valorização da ordem e respeito à mesma, o que poderia explicar a frequência de atos diretivos envolvidos nessa temática no corpus chileno. Nesta mesma amostra, após a aceitação do pedido do falante $\mathrm{B}$, de maneira mais direta C propõe como quer começar a reunião - "yaa / ya partimoh con la segunda materia / ya naa'a dee / el siglo del oro" -, com uma intervenção iniciada com o a partícula metadiscursiva "ya", para cortar o discurso do interlocutor e propor outro tópico, realizando uma operação enunciativa que pode mostrar o controle da comunicação por parte do falante que o emprega. De igual modo, em seguida D realiza a sua proposta - "[(pero hablamoh del] el valor pu 个]" - marcando a orientação argumentativa com "pero" e intensificando a expressão de sua opinição mediante o modalizador "pu pues".

No próximo evento comunicativo a ser analisado, participam sete estudantes da Faculdade de Educação, dois homens e cinco mulheres, e neste encontro de estudos, notamos que em variadas sequências, possivelmente devido às mudanças de tópicos conversacionais, jovens diferentes dominam os turnos e controlavam a interação verbal em situaçãos diferentes. Selecionamos duas amostras, a de número (7), ocorrida aos vinte e quatro segundos do início da gravação e da reunião, e a amostra (8), registrada aos cinquenta e nove minutos da gravação que tem como total uma hora e dois minutos.

(7)

A: yo creo que primero deberíamos ver la cuestión de loo / de loh tiempoh $\uparrow$ / porque estamoh súper ajustadoh $\uparrow$ / ((pa que noh empecemoh)) a dividir tareeas $\uparrow$ / porque de aquí a hacerlo en conjuunto $\uparrow$

B: es que / yo creo / (()) tenemos que traer ((la)) problemática $\uparrow$ / y que tan acotadoo seea $\uparrow /$ lo damos

C: $[(())]$ según $(($ los grupos $)) \downarrow$ claro po $\uparrow$ / que yo le de- yo creo que deberíamos dejar como las temáticas ahora $\uparrow / /$ y empezar altiro a alinear cuestiones pa qué1 próximo lunes tengamos como el / el proyecto ma- medianamente armao $\uparrow$ / ((lo que pretendemos))

D: sí po $\uparrow /$ sabî $\uparrow$ / pa que noh diga si en verdá' está bien po

C: por ejemplo $\uparrow$ / yo todavíaa noo / no entiendo bien $\uparrow / / /$ que vamoh / supuestamente en la temáticaaa ee / ((de loh díaah) $) /$ en que soon $=\S$ 
(8)

C: son ustedes tres y nosotras cuatro $\uparrow$

?: ¡chaa! / ( ¡cómo que ellos treh!))

?: a verdá cuatro

C: entonces Miguel es loh objetivoh $\uparrow$

E: objetivo y metodología $\uparrow$

C: ya $\downarrow$

B: [pero es que yo quiero-]

C: ¿y los OTROH? $\uparrow /$ hacen la portada y el índice $\uparrow$

(RISAS)

E: ((la wea colegio) $) \downarrow$

A: y lo van a anillar $\uparrow$

C: y lo van a anillar $\uparrow /$ creo que eh un trabajo bastante importante ya $\uparrow$

D: yo creo que no porque está súper desigual $\uparrow$

C: $(())$

E: noo $\uparrow$ / nosotros no podemos hacer la metodolo- nosotros vamos a estructurar

C: noo chiquillos / ustedes se encargan de- entrevistas / metodología / y objetivos

E: y la- entonces la metodología también sería toda la investigación que hay que hacer $\downarrow$ 2"

C: no po / no po /es que la- en trevista todavía no veamos eso

B: ah ya / hagamos esto primero $\downarrow$

E: a ya $\downarrow$

C: (()) lo que yo digo es que / loh OBJETIIVOS =

E: esto es pal proyecto claro $\downarrow$

$\mathrm{C}:=$ planteen una metodología en términos generales / es / una pegaa $\rightarrow$ / muy corta / pero ((hacemoh un marco teóricoo))

B: $[(())]$

E: ¿corta $\uparrow$ ? // ¿sabí cuántos meses me demoré en hacerlo? $\uparrow$

(RISAS)

Vale ressaltar o fato de haver mais estratégias de cortesia na amostra (7) do que na (8), como recursos de atenuação que debilitam a força argumentativa, que previnem ou que reparam, que protegem as imagens dos ouvintes e do falante, com o verbo perfomativo "creo" e modificações do verbo colocado no tempo condicional em espanhol "deberíamos".

Além disso, a amostra (7) possui mais atos que justificam as exortações, envolvidas na orientação argumentativa - "porque estamoh súper ajustadoh $\uparrow$ / ((pa que noh empecemoh)) a dividir tareeas $\uparrow$ / porque de aquí a hacerlo en conjuunto 1"; "pa que'l próximo lunes tengamos como el / el proyecto ma-

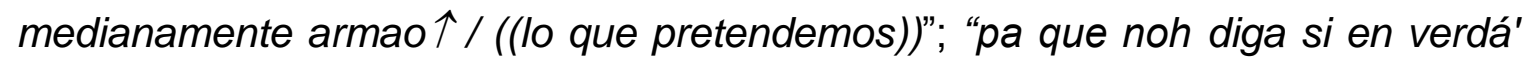
está bien po". 
No fragmento (8), o ato diretivo de petição similarmente participa na orientação argumentativa e faz parte de uma intervenção reativa; dentro do plano dialogal. Temos que $C$ expressa desacordo com $E$ sobre como organizar a divisão de tarefas no desenvolvimento do trabalho de pesquisa que devem realizar - "no po / no po /es que la- en trevista todavía no veamos eso". A força ilocutoria da negação é intensificada pelo marcador modalizador "po (pues)" e, com uma forma imperativa, temos um ato exortativo - "veamos eso", acatado por B - "ah ya / hagamos esto primero ل", que expressa o acordo por meio do marcador de modalidade "ah ya" que marca o início da intervenção, revelando o seu caráter reativo; em seguida, o acordo se confirma com um ato exortativo que apóia a proposta de C. Observamos que esses atos diretivos são exemplos de de atos verbais diretos, sem mostrar cortesia não manifestam consideração pela imagem do ouvinte, contudo não podemos afirmar que são atos típicos de "hablantes emocionados o enfurecidos", como asseverou Haverkate (1994: 22). Esta interpretação deve fundamentar-se nas premissas culturais dos participantes da interação verbal como também nas características da própria situação comunicativa, igualmente não é possível que conheçamos características individuais e sentimentos de cada interactante.

O que podemos depreender desse contexto comunicativo é que a presença de mais estratégias de cortesía ao início do que ao final da reunião de estudos não se explica apenas porque, após quase uma hora reunidos, o grau de informalidade, confiança e familiaridade poderia favorecer a produção de atos de fala mais diretos, mas também tal fato se dá devido a características específicas da situação comunicativa do fragmento (8), em que o trabalho de imagens se intensifica quando faces são ameaçadas na argumentação sobre a divisão das tarefas de que cada participante vai se encarregar - " $D$ : yo creo que no porque está súper desigual $\uparrow$ " -, quando na discussão também surge o tópico sobre a quantidade de tempo que se gasta para cada parte do trabalho: " $C$ : (...) es / una pegaa $\rightarrow$ / muy corta (...)"; "E: ¿corta ?? // ¿sabí cuántos meses me demoré en hacerlo? $\uparrow$ (RISAS)".

No corpus brasileiro, encontramos situações comunicativas que se aproximam a algumas que analizamos no corpus chileno, porém em menor quantidade. De 16 eventos gravados, somente em 5 (31,25\%) observamos a 
preocupação com ordem da reunião, logo, em 11 (68,75\%), esta preocupação não foi enunciada. Vejamos um exemplo:

(9)

$\S$ eu vou bandeijar porque sou obrigado $\S$

I: $\quad \S$ que tem pra hoje?

F: oi? $\S$

A: $\S[$ macarrão $] \S$

D: $\quad \S$ arroz / feijão $\S$

B: $\quad \S$ refresco $\S$

A: $\quad \S$ [macarrão ao sugo] $\S$

E: $\quad \S$ [mas química] é tão química $\S$

I:

química ano passado $\S$

$\S$ eu ia muito à

D: [química é ótimo]

E: [eu não gosto de comer na química§]

F: $\quad$ (es)pera / (es)pera / no lugar do arroz? $\S$

E:

colher fica horrível $\S$

$\S$ eu acho // a

A: $\quad$ $\quad$ tipo / bife com molho/ sei lá $\S$

I:

$\S$ no central? §

A:

F: na [química]

A: [na] química $\S$

E: $\quad$ [§ e eu acho a comida do central muito gostosa $(())]$

A: [bife não sei com o que e macarrão // não gosto de macarrão]

$\mathrm{H}:$

D: o suco da química é muito ruim

$\S$ pauta da RO / bandejão

B: [suco é ruim]

C: o suco da [química é resto de experimentos]

D: [e não fazem experimentos]

E: o feijão não é bom $\S$

I: $\quad \S$ eu não gosto da escada

C: suco de cobre, suco de magnésio

F: [suco de cobre (RISOS)] §

D:

F:

$\S$ vamos começar? $\uparrow \S$

D:

\section{§vamos lá galera? $\uparrow$ vamos lá§}

§eu

vou começar com as pautas mais ou menos depois começo com umas pautas mais legais/ vamos lá: festival de natação da E.F.E. / o que ser isso? §

(BRAABCDEFGHI29/04/2014)

Neste encontro, há nove estudantes de jornalismo da USP, que se reúnem periodicamente para a elaboração de artigos. A amostra (9) faz parte do início da gravação e da reunião, e vemos que, após a demonstração de que o tema sobre o "bandeijão", o restaurante universitário, estava se estendendo - " $H$ : pauta da RO / bandejão" -, através da intervenção irônica de $\mathrm{H}$, o falante D 
realiza a proposta de começar a reunião e recebe o apoio de $F-$ " $D$ : vamos começar? $\uparrow$. Devemos evidenciar que $\mathrm{H}$ é uma das responsáveis por dirigir a reunião- e ocupa, portanto, posição hierárquica distinguida.

$O$ falante $D$ possivelmente avalia que o momento em que todos riem é um lugar relevante para tomar a palavra e enunciar um ato exortativo. Esse ato inclui uma estratégia de atenuação, o chamado "nosotros inclusivo" (Haverkate, 1994:31), que reforça os laços de amabilidade, protege as faces do falante e ouvintes e reforça as relações igualitárias, pois, de certa maneira, o falante está realmente incluído na tarefa de começar a tratar dos temas da pauta da reunião.

Neste mesmo fragmento também, quando o tema sobre o restaurante universitário era distendido, o falante $F$ rouba a palavra e enuncia um ato exortativo direto, sem manifestar cortesia - "§(es)pera / (es)pera / no lugar do arroz?§" -, mas não consegue desenvolver o tópico conversacional, logo lhe roubam o turno, no entanto, não se vê nesta situação comunicativa a interpretação de algum conflito social.

Pouco depois, neste mesmo encontro, ocorreu a situação (10).

(10)

$\mathrm{H}:$

[= mandem por e-mail] por inbox por whatsapp sei lá

// porque assim / eu não consigo estar presente aqui // mas por e-mail eu sempre procuro sei lá ajudar vocês de alguma forma / [então] §

A: $\quad \S$ [e às vezes] / não precisa mandar ideia só pro diretor do seu grupo se você tem uma ideia pra qualquer outra coisa pra outro núcleo $\mathrm{x} /$ mandem inbox pros diretores podem falar: [é isso o que a gente quer sabe?] $\S$

C:

A:

$\S$ [amo $\uparrow$ ideias pro administrativo]

[produtividade]

[a gente ama ideias $\uparrow] / / \mathbf{a m a} \uparrow$

(RISOS)

B: $[(($ criatividade $)) \uparrow]$ gente $(())$ no administrativo / [((tamo)) aceitando $\uparrow] \S$

A: $\quad \S[$ então/ sério mesmo] / venham com ideias venham com coisas que a gente não perde essas coisas a gente deixa guardado pro futuro ou pra agora // mas é bacana isso // e falando em ideias [vamos pra segunda parte da $\mathrm{RO}$ vai]

(BRAABCDEFGHI29/04/2014)

Os falantes $\mathrm{A}, \mathrm{B}, \mathrm{C}$ e H dirigem a reunião neste momento e solicitam aos demais o envio de ideias. $\mathrm{H}$ emprega um ato exortativo direto - "I= mandem por e-mail] por inbox por whatsapp" -, através de uma forma verbal no modo imperativo, sem manifestar cortesia, porém, em seguida, expressa um ato de 
justificação - "porque assim / eu não consigo estar presente aqui // mas por email eu sempre procuro sei lá ajudar vocês de alguma forma / [então] §" - que está envolvido na orientação argumentativa.

Além disso, com base na escala de custo-benefício (Leech, 1983), em que o pedido implica algum custo para o ouvinte e certo benefício para o falante, $\mathrm{H}$ evidencia consideralmente a diminuição do custo para os ouvintes valorizando-os em "eu sempre procuro sei lá ajudar vocês de alguma forma", embora atenue esta aseveração com o marcador modalizador "sei lá", podendo assim evitar as possíveis responsabilidades do falante com relação à verdade ou ao cumprimento do que foi dito além de exercer um papel importante na formulação do enunciado.

Em seguida, a falante A se utiliza da mesma estratégia, um ato exortativo direto seguido da expressão da valorização dos ouvintes em "mandem inbox pros diretores podem falar: [é isso o que a gente quer sabe?]" e em "venham com ideias venham com coisas que a gente não perde essas coisas a gente deixa guardado pro futuro ou pra agora // mas é bacana isso // e falando em ideias [vamos pra segunda parte da RO vai]". Inclusive essa lógica relacional é reforçada com o ato expressivo "é bacana isso", favorecendo a imagem do ouvinte que vai contribuir, ato que participa também da orientação argumentativa desta sequência conversacional.

A e C utilizam também a estratégia de apelar para solidadariedade dos ouvintes e também de produzir a impressão de que não tem o propósito de ameaçar a sua liberdade de ação (imagem de autonomia) ao emitirem " $C$ : $\S$ [amo $\uparrow$ ideias pro administrativo]" e "A: [a gente ama ideias $\uparrow$ ] // ama $\uparrow$ [produtividade]".

Nos casos analisados em (10), a imagem de cordialidade dos falantes é fortalecida, ao se mostrarem amigáveis, permitir que os ouvintes tenham opções, evidenciando o respeito ao interlocutor. Igualmente, a imagem de semelhança é reafirmada porque os falantes fortalecem com o interlocutor a semelhança com ele.

Vimos igualmente neste corpus que quando o falante ocupa uma posição hierárquica de menos destaque, manifesta também estratégias de cortesia ao realizar um ato exortativo. 
(11)

A B: éh oh/// ((por mais que eu pressinta o fim da euforia não posso negar que estou contente com o que vejo $\downarrow /$ hum/ volto-me então para// a sala me estico de costas para o sofá o corpo todo do e blá blá o pior não é isso na verdade já sei o que esperava a noite $))^{45} / / /$ aí a noite é a hora que ele fala oh ((o aviso não rebate falso o primeiro contato com o travesseiro esbarro na minha perna) $)^{46} /$ que aí ele começou a briga com ele//

A: acho que a gente tem que colocar isso $\S$

$B$ : §acho que a gente pode falAR/ que quando ele estava tentando se manter ocupADO/ ele tá consciente $\uparrow$ ((aqui))

A: então tá/ são descritas/ a gente pode falar assim $/{ }^{47}$ o(são descritas) ${ }^{\circ}$ ações/// que/// ahn:: //denotam/// uma// necessidade/// do personagem de manter-se ocupado

B: ahn ahn

A: do personagem/// em manter-se ocupado 48 (6") a fim de evitar// ou retardar ¿né?

B: éh

(BRASL07/12/2009)

Nesta amostra, duas participantes, ambas do segundo semestre do curso de Letras da USP, elaboram juntas o trabalho final da disciplina de Introdução aos Estudos Literarios II. A falante B revela mais conhecimento da matéria e se posiciona no ponto mais elevado na relação hierárquica. Neste encontro de estudos, que já foi examinado na seção que tratou da autorrepetição, constantemente B corrige a A e evidencia a sua imagem de hierarquia, porém, ao enunciar não enuncia um ato exortativo, mas sim uma asserção em: “ $\boldsymbol{B}$ : §acho que a gente pode falAR/ que quando ele estava tentando se manter ocupADO/ ele tá consciente $\uparrow$ ((aqui))", e repete a mesma estratégia que sua interlocutora $\mathrm{B}$ manifestou no turno anterior - "A: acho que a gente tem que colocar isso§" -, em que temos uma atenuação da força argumentativa com o verbo performativo "achar", o que subtrai a responsabilidade do falante com relação ao que diz e, além disso, previne ou repara ameaças às faces.

Vemos estratégias de atenuação também em atos exortativos de $A$ e $B$ nos trechos abaixo:

(12)

A: falamos do tempo/ o tempo é subjetivo ¿a gente falou isso?

B: não// tem que concluir isso

A: é na hora que a gente falar// isso aqui/ quer ver oh?// pode ser uuum ganchinho aqui quer ver oh? $((\quad))^{49}$

\footnotetext{
${ }^{45}$ Leitura.

${ }^{46}$ Leitura.

${ }^{47}$ A dita o que escribe no caderno.

${ }^{48} \mathrm{~A}$ dita o que escreve no caderno.

${ }^{49}$ Lê o que foi redigido.
} 
B: ((¿quantas páginas já deu isso?))

A: é que meu letrão é novo

B: (RISOS)

(BRASL07/12/2009)

(13)

A: ${ }^{50} \mathrm{e}$ a::/ é quase que é uma/ obrigação dele se encarar a si próprio de conviver com ele mesmo/ ¿né?

B: ahn ahn

A: ${ }^{51}$ e a:: quase/// obrigação/// ou necessidade// depois (vo)cê muda alguma coisa se (vo)cê achar que§

B: $\quad \S a h n$ ahn

A: se alguma coisa não fizer sentido $/ / /^{\circ}$ (necessidade $)^{\circ} /$ ae/ pois é exatamente quando se encerram sua atividades cotidianas domésticas/ que de certa forma o conectam com o mundo real/// que surgem suas alucinações e a quase obrigação/ decorrentes da quase obrigação// e da necessidade de:: se enxergar a si próprio/ de conviver com ele mesmo

(BRASL07/12/2009)

Valorizando a imagem de hierarquia de sua interlocutora $B$, que é a aluna que demonstra mais poder hierárquico, a falante $A$ lhe oferece opções em (12) a partir de uma pergunta - "quer ver oh?". E em (13) também com um ato indireto que se assemelha à uma recomendação em benefício do trabalho de ambas, do trabalho grupal - “depois (vo)cê muda alguma coisa se (vo)cê achar que§”. Ressaltamos que realizar um ato diretivo em forma de pergunta manifesta maior grau de cortesia em comparação com um ato direto e sinaliza mais empatia ao interlocutor ao indagar-lhe sobre sua disposição ou condições para realizar o pedido.

No âmbito histórico e social do Brasil, de marcada formação hierárquica e de desigual divisão de poderes, de que discorremos nesta tese, pode fazer com que formas verbais em imperativo, na sociedade brasileira, causem algum tipo de conflito social em relações de igualitária divisão de poder social, pelo fato de o falante não mostrar cortesia ou consideração pela imagem do ouvinte.

Nesse sentido, selecionamos dois exemplos de um mesmo evento comunicativo em que, em situações comunicativas diferentes, o mesmo falante realiza um ato exortativo mediante uma forma verbal em presente do indicativo e recursos de atenuação e, em outro momento, com uma forma verbal em imperativo.

\footnotetext{
${ }^{50}$ Faz um gesto afirmativo com a cabeça.

${ }^{51}$ Redige o que acabam de debater.
} 
(14)

A: são expectadores pode-se dizer

B: espectadores

A: é/ porque vai depender/ você pode escrever até ¿né? de acordo com o evento/ os espectadores vão ser de um tipo/por exemplo no::/ sei lá/eh::/ panegírico// (vo)cê vai ter um tipo de espectador// um tipo de espectadores/ se for um:: dis/ um:/ uma homenagem fun-um discurso fúnebre ¿que se fala?// uma oração fúnebre/ vai ser outra coisa/ e assim por diante/ aí você/ ponto final/ aí no próximo parágrafo/ você coloca assim/ Aristóteles/ ainda// eh::/ ainda fez uma classificação de acordo/ com/ com o que ele precisava no discurso/ cada um desses três gêneros / ¿não é isso?

B: eh::

A: aÍ você pode falar/ ¿qual é o deliberativo?

B: é o tempo futuro

(BraFAFB03/12/2009)

(15)

B: à medida que/ são discutidos/ é o que virá/ futuramente/ ((postumamente))/ em benefício da pólis/ do estado/ (( escravizava o povo ou não/ ((

)) discutir as questões de fazer guerra ou não/ se A: $\S^{\circ}(((\text { nossa/ escravizava o povo })))^{\circ} /$ toma cuidado com esse tipo de alusão $\downarrow \S$

B: §enfim $((\quad)) /$ beneficen/ beneficente para Roma.

A: uma coisa importante/ outra coisa importante/ tá vendo essa (( $\quad){ }^{52} /$ fala sobre Aristóteles

B: ahn ahn

(BraFAFB03/12/2009)

Interagem dois estudantes, ambos do sexo masculino, que se preparam juntos para uma prova de Estudos Clássicos II, disciplina de literatura da Faculdade de Letras da USP. Vimos alguns fragmentos deste evento comunicativo na seção que tratou da autorrepetição, em que notamos que o falante A é quem domina a maioria das intervenções, desempenhando o papel de "aluno-professor". Enquanto $B$ redige as respostas de questões em debate, $A$ o orienta no exemplo (14), salvaguardando o "eu" e também o seu ouvinte, prevenir possíveis danos às imagens ou, ainda, problemas causados pela intromissão ou invasão do território ou espaço do outro (Briz, 2013). Assim, em “você pode escrever até ¿né?" e "aí você pode falar" se destaca a presença do modalizador "poder"; e em "você coloca assim", o uso do presente do indicativo que também atenua o ato exortativo instrucional.

O marcador conversacional "né?" apela à ouvinte e chama-lhe a atenção sobre a instrução comunicada previamente, que é apresentada como se fosse compartilhada por este, favorecendo as imagens de semelhança e cooperação.

\footnotetext{
${ }^{52}$ Aponta para o texto.
} 
No exemplo (15), o imperativo se encontra em um ato exortativo não impositivo, uma recomendação - "toma cuidado com esse tipo de alusão $\downarrow$ ”" -, que, provavelmente, por beneficiar ao ouvinte, foi realizada de maneira direta, lembrando que o uso do modo imperativo não exclui uma interpretação cortês que dependerá de características de cada situação comunicativa (Haverkate, 1994: 162).

No sudeste do Brasil, frequentemente, embora seja usado o pronome de segunda pessoa do singular (você) como tratamento em conversações coloquiais, no modo imperativo ocorre a forma verbal de segunda pessoa do singular (tu), de maneira que temos "toma você" no lugar de "tome você". Esse fato pode ser um indício de uma permuta entre presente do indicativo e o modo imperativo, uma vez que vemos no corpus uma tendência alta dessa forma no âmbito morfológico. Embora saibamos que a prosódia desempenha importante papel na ocorrência de atos diretivos e modalização dos mesmos, não será o foco desta etapa da pesquisa que desenvovemos aqui.

Neste estudo, sempre levamos em conta a possibilidade de variações situacionais e até mesmo interpessoais ou individuais. Por isso, lembramos que os dados de frequência relacionados aos atos de fala são reconhecidos aqui como pistas que guiam as interpretações e a discussão dos resultados, não como um dado categórico. Compreendemos que, de um lado, os comportamentos dos interlocutores podem ser guiados por suas próprias motivações pessoais, e não sempre pelas premissas culturais compartilhadas; de outro, as variadas diferenças contextuais de cada situação comunicativa permitiriam também alterações nos resultados.

\subsubsection{Apresentação dos resultados: atos diretivos e as estratégias de cortesia envolvidas na construção da imagem dos participantes da interação brasileira e chilena}

Um ato exortativo pode ser realização de forma direta nas interações entre os participantes do corpus brasileiro, seguido de estratégias alocêntricas como um ato de justificação ou a expressão da diminuição do custo para os 
ouvintes, com base na escala de custo-benefício (Leech, 1983), posto que o pedido implica algum custo para o ouvinte e certo benefício para o falante. Dessa maneira, a imagem de cordialidade dos falantes é fortalecida; ao se mostrarem amigáveis, valorizando o interlocutor.

Os estudantes chilenos do corpus realizaram atos exortativos de maneira direta principalmente quando um interactante sentia a necessidade de projetar uma valorização da ordem e respeito à mesma, mostrando o controle da comunicação mediante uma petição que frequentemente não apresentava recursos de atenuação. Em situações análogas no corpus brasileiro, o falante mostra o controle da comunicação mediante uma petição para a manutenção da ordem da reunião que frequentemente apresenta recursos de atenuação, que reforçam os laços de amabilidade, protegem as faces do falante e ouvintes e valorizam as relações igualitárias.

No corpus brasileiro observamos que em $31,25 \%$ das situações comunicativas enunciou-se a preocupação com a ordem da reunião, mas no corpus chileno a proporção é maior, $85,71 \%$. Essa diferença pode dar-se porque, por um lado, no contexto social chileno a necessidade de projetar uma valorização da ordem e respeito à mesma é um valor social influente. Por outro, constatamos que a dinâmica das interações favorece mais ou menos a necessidade de divisão de tarefas e de organização durante os encontros de estudos.

Nos encontros brasileiros em sua maioria temos duplas, enquanto que os encontros de estudos chilenos em geral contavam com mais de três participantes, o que pode requerer mais esforço para alcançar-se o consenso e a ordem. É necessário ressaltar também que o tipo de atividade que desempenham os estudantes aumenta ou diminui o grau de preocupação com a ordem, uma vez que notamos que no Chile, é muito comum que os alunos elaborem juntos, como exigencia das práticas universitárias, trabalhos de investigação científica, que exigem mais esforços relativos ao respeito à forma, à profundidade no tratamento dos temas, à escrita à sistematização de ideias, a sistematização de referenciais teóricos e demais práticas de pesquisa. Em nossas gravações, em 8, dos 14 eventos que compõem nosso material de análise chileno os estudantes implicados realizavam trabalhos de pesquisa. No material de análise em português, como nos demais encontros chilenos, as 
atividades de prática universitária em grupo variam entre traduções, discussão de respostas de questionários, análise de textos literários, elaboração de apresentação oral, etc.

No material de análise brasileiro, atos exortativos podem ser realizados de maneira indireta e há casos em que o interlocutor evidencia a imagem de hierarquia do outro ao não realizar um ato exortativo, mas sim uma asserção, em que ocorre a atenuação da força argumentativa; para subtrair a responsabilidade do falante com relação ao que diz e, além disso, prevenir ou reparar ameaças às faces de falante e ouvinte. Um falante também pode realizar um pedido indireto, em forma de pergunta, oferecendo opções, sinalizando mais empatia ao interlocutor ao indagar-lhe sobre sua disposição ou condições para realizar o pedido.

Mecanismos de atenuação que destacam a presença do modalizador "poder", estratégia pseudoinclusiva (uso da primeira pessoa do plural) e o uso de verbos em presente de indicativo foram encontrados nos materiais de análise chileno e brasileiro.

Nas interações chilenas, encontramos pedidos convencionais diretos ou indiretos. Especialmente em relação com a distância social, percebe-se o uso convencional de um pedido indireto, marcado também pelo tom informal que reforça a afiliação e a presença do modificador verbal e modalizador frequente na linguagem juvenil chilena "porfa" (por favor). A ausência do agradecimento pode dar-se devido à avaliação de que não haverá relevante desequilíbrio social numa situação comunicativa em que a imposição do ato não é proeminente e a informalidade é alta. Podem ocorrer também atos diretivos que se interpretam como ameaçadores, porém, ao mesmo tempo, tratam-se de fórmulas convencionais em imperativo em situações coloquiais e juvenis o que thes diminui a força ilocutoria.

Em seguida, são apresentados estes resultados de maneira sucinta, em quadros descritores. 


\section{QUADRO 5 - ATO EXORTATIVOS E ESTRATÉGIAS DE CORTESIA ENVOLVIDAS NA CONSTRUÇ̃̃O DA IMAGEM DOS PARTICIPANTES DE}

GRUPOS DE ESTUDOS ACADÊMICOS EM SÃO PAULO (BRASIL)

\section{PAPÉIS PRAGMÁTICOS}

1) Realização direta seguido de estratégias alocêntricas: o ato de pedir pode ocorrer através de uma forma verbal no modo imperativo, sem manifestar cortesia, seguido de ato de justificação ou da expressão da diminuição do custo para os ouvintes, com base na escala de custo-benefício (Leech, 1983). A imagem de cordialidade dos falantes é fortalecida, ao se mostrarem amigáveis, valorizando o interlocutor.
$\S$ [e às vezes] / não

precisa mandar ideia só pro diretor do seu grupo se você tem uma ideia pra qualquer outra coisa pra outro núcleo $\mathrm{x} /$ mandem inbox pros diretores podem falar: [é isso o que a gente quer sabe?]§

$\mathrm{C}: \quad \S[$ amo $\uparrow$ ideias pro administrativo]

A: [a gente ama ideias $\uparrow]$ // $\operatorname{ama} \uparrow$ [produtividade] (RISOS)

B: $\quad[(($ criatividade $) \uparrow \uparrow]$ gente $(())$ no administrativo / [((tamo)) aceitando $\uparrow] \S$

A: $\quad \S[$ então/ sério mesmo] / venham com ideias venham com coisas que a gente não perde essas coisas a gente deixa guardado pro futuro ou pra agora // mas é bacana isso // e falando em ideias [vamos pra segunda parte da RO vai]

(BRAABCDEFGHI29/04/2014)

2) Realização indireta ou não realização: Um interlocutor pode evidenciar a imagem de hierarquia do outro ao não realizar um ato exortativo, mas sim uma asserção, em que ocorre a atenuação da força argumentativa, para subtrair a responsabilidade do falante com relação ao que diz e, além disso, prevenir ou reparar ameaças às faces de falante e ouvinte. Um falante também pode realizar um pedido indireto, em forma de pergunta, oferecendo-lhe opcões, sinalizando mais empatia ao interlocutor ao indagar-lhe sobre sua disposição ou condições para realizar o pedido.

A: falamos do tempo/ o tempo é subjetivo ¿a gente falou isso?

B: não// tem que concluir isso

A: é na hora que a gente falar// isso aqui/ quer ver oh?// pode ser um:: ganchinho aqui quer ver oh? (( )$)^{53}$

B: ((¿quantas páginas já deu isso?))

A: é que meu letrão é novo

B: (RISOS)

(BRASL07/12/2009)

${ }^{53}$ Lê o que foi redigido. 
3) Mecanismos de atenuação: se destacam a presença do modalizador "poder", estratégia pseudoinclusiva (uso da primeira pessoa do plural) e o uso de verbos em presente de indicativo em mecanismos de atenuação do falante e da força ilocutoria do enunciado. Numa relação social assimétrica entre os interlocutores, produzem o efeito de solidariedade e reforçam a imagem de semelhança.

Quando um interactante sente a necessidade de projetar uma valorização da ordem e respeito à mesma, mostra o controle da comunicação mediante uma petição que frequentemente apresenta recursos de atenuação, que reforçam os laços de amabilidade, protegem as faces do falante e ouvintes e valorizam as relações igualitárias.
A: (...) um tipo de espectadores/ se for um:: dis/ um:/ uma homenagem fun-um discurso fúnebre ¿que se fala?// uma oração fúnebre/ vai ser outra coisa/ e assim por diante/ aí você/ ponto final/ aí no próximo parágrafo/ você coloca assim/ Aristóteles/ ainda// eh::/ ainda fez uma classificação de acordo/ com/ com o que ele precisava no discurso/ cada um desses três gêneros / ¿não é isso?

B: eh::

A: aÍ você pode falar/ ¿qual é o deliberativo?

B: é o tempo futuro

(BraFAFB03/12/2009)

E: o feijão não é bom $\S$

I:

C: suco de cobre, suco de magnésio

F: [suco de cobre (RISOS)] $\S$

D:

$\mathrm{F}$.

$\S$ vamos começar? $\square$

vamos lá

D: $\quad \S$ eu vou começar com as pautas mais ou menos depois começo com umas pautas mais legais (...) 


\section{QUADRO 6 - ATO EXORTATIVO E ESTRATÉGIAS DE CORTESIA ENVOLVIDAS NA CONSTRUÇÃO DA IMAGEM DOS PARTICIPANTES DE GRUPOS}

DE ESTUDOS ACADÊMICOS EM SANTIAGO DO CHILE

\begin{tabular}{|c|c|}
\hline PAPÉIS PRAGMÁTICOS & EXEMPLOS \\
\hline $\begin{array}{l}\text { 1) Realização direta: quando um interactante sente a necessidade de projetar uma valorização } \\
\text { da ordem e respeito à mesma, mostra o controle da comunicação mediante uma petição que } \\
\text { frequentemente não apresenta recursos de atenuação. }\end{array}$ & $\begin{array}{l}\text { C: noo chiquillos / ustedes se encargan de- entrevistas / } \\
\text { metodología / y objetivos } \\
\text { E: y la- entonces la metodología también sería toda la } \\
\text { investigación que hay que hacer } \downarrow \\
2 " \\
\text { C: no po / no po /es que la- en trevista todavía no veamos } \\
\text { eso } \\
\text { B: ah ya / hagamos esto primero } \downarrow \\
\text { E: a ya } \downarrow\end{array}$ \\
\hline $\begin{array}{l}\text { 2) Pedido (in)direto convencional: sobretudo em relação com a distância social, percebe-se o } \\
\text { uso convencional de um pedido indireto, marcado também pelo tom informal que reforça a } \\
\text { afiliação e a presença do modificador verbal e modalizador frequente na linguagem juvenil } \\
\text { chilena "porfa" (por favor). A ausência do agradecimento pode dar-se devido à avaliação de } \\
\text { que não haverá relevante desequilíbrio social numa situação comunicativa em que a imposição } \\
\text { do ato não é proeminente e a informalidade é alta. } \\
\text { Podem ocorrer atos diretivos que se interpretam como ameaçadores, porém, ao mesmo tempo, } \\
\text { se tratam de fórmulas convencionais em imperativo em situações coloquiais e juvenis, o que } \\
\text { lhes diminui a força ilocutória. }\end{array}$ & $\begin{array}{l}\text { B: emmm/ ya } \downarrow / \text { y el auge de la cultura audiovisual } \downarrow \\
\text { A: auge de la cultura audiovisual } \downarrow \text { / en la simple } \rightarrow \\
\text { D: oye } \downarrow / \text { hola / me podí prestar fuego porfa } \\
\text { A: acá está } \downarrow \\
\text { A: en la simple los (()) resultaban fundamentales para la } \\
\text { construcción del orden republicano y de la política } \downarrow / / \text { los } \\
\text { liberales contractualistas planteaban que los medios debían } \\
\text { ser autónomos de los poderes estatales } \square(. . .) \\
\text { C: ((oye)) ¿alguien sabe como decir ballena? / pa'que } \\
\text { pongamos ballenah } \rightarrow \\
\text { B: ballena ballena } \downarrow \text { / ¿de ballena? } \uparrow \\
\text { A: noo cómo se te ocurre } \\
\text { B: de oorca / calla } \downarrow \\
\text { C: ¿orca? } \\
\text { D: de orca (RISAS) }\end{array}$ \\
\hline
\end{tabular}


3) Mecanismos de atenuação: se destacam a presença do modalizador "poder", estratégia pseudoinclusiva (uso da primeira pessoa do plural) e o uso de verbos em presente de indicativo em mecanismos de atenuação do falante e da força ilocutoria do enunciado.. Numa relação social assimétrica entre os interlocutores, produzem o efeito de solidariedade e reforçam a imagem de semelhança.
A: [i, y eso? ¿arriba?] /// donde dice / eso (( )) puro $\uparrow /$ podríamooh pegarloh aquí mismo / e- es anteh del híbrido $\rightarrow$

B: aah ya $\downarrow / / /$ y esto lo copié tal cual como estaba (( )) en el otro liibro por eso (quedó así)

$7^{\prime \prime 5}$

B: esto (())

$14 " 55$

A: ¿por quée (( )) /// ee /// a su vez?

B: (no puede subdividiirSE / en)

\section{(RISAS)}

A: no mejor no si está muy bien (( )) para que le pusierai / se puede subdividirse

\footnotetext{
${ }^{54}$ Leitura silenciosa.

${ }^{55}$ Leitura silenciosa.
} 


\section{O TESTE DE HÁBITOS SOCIAIS}

Para uma investigação contrastiva, os chamados testes de hábitos sociais são ferramentas válidas que possibilitam averiguar como os falantes avaliam o comportamento cortês em suas próprias comunidades de fala (Hernández Flores (2002, 2006), Contreras (2004) e Bernal (2007)).

Os testes de hábitos sociais são questionários escritos que servem para apoiar dados extraídos de um corpus e podem ser realizados através de entrevistas com perguntas abertas, formulários com perguntas de seleção múltiple (sendo que as questões não são criadas aleatoriamente, mas, no geral, com base nas respostas obtidas mediante um um teste de perguntas abertas) e também a partir de questionários que solicitam que os informantes adotem uma função ou um papel que desempenhariam em determinados contextos, expressando as suas opiniões (Hernández-Flores, 2006).

De acordo com Bernal (2007), as informações que fornecem os testes são metapragmáticas. Para Kasper (2000) e Hernández-Flores (2006), os dados obtidos não informam sobre o uso real que os informantes fazem da linguagem, mas nos concedem as percepções e reflexões a respeito dele.

Nesta pesquisa, estes testes constituem uma contribuição para nossos objetivos, uma vez que servem como material de apoio para extrair informações do contexto sociocultural, dos pressupostos dos falantes sobre as estratégias sociais válidas em suas comunidades de fala e sobre como thes parece (in)adequado atuar numa interação.

Algumas questões do teste que elaboramos para o atual estudo se fundamentaram em aspectos que nos chamaram a atenção nas duas etapas de investigação anteriores, a análise do corpus e a pesquisa interdisciplinar, como também nas pesquisas realizadas por Lopes e Andrade (2012) e Andrade (2014), que apresentaram os resultados de testes respondidos por trinta estudantes da Universidad de Santiago de Chile (USACH) e trinta estudantes da Universidade de São Paulo. A partir disso, puderam ser extraídas algumas noções sobre os pressupostos subjacentes à manifestação das estratégias que operam no equilíbrio na interação verbal. 
A partir dessas contribuições, encontramos pistas sobre as singulares diferenças entre a forma como estudantes brasileiros e chilenos avaliam as funções da cortesia na universidade e a dinâmica das relações sociais.

Nesta etapa, portanto, discutimos os resultados dos testes de hábitos sociais que foram formulados para a atual pesquisa, cujas respostas podem corroborar as interpretações do corpus, como também as características da imagem social e dos valores culturais subjacentes ao comportamento cortês que apresentamos.

Recordamos que na etapa anterior, de análise do corpus oral, identificamos aspectos linguísticos, comunicativos e conversacionais, usando como critérios de análise o que se depreendeu da etapa do enfoque interdisciplinar. A prévia descrição de algumas características das premissas culturais e dos conteúdos específicos da imagem social básica, nas comunidades de fala em estudo, pôde compor nossos critérios na análise do corpus, em que selecionamos atos diretivos e assertivos e examinamos a expressão das estratégias pragmáticas envolvidas na co-construção das imagens dos interlocutores em uma interação.

Queremos evitar, com a presente etapa, a possibilidade de que, como analistas, infiramos das primeiras fases da pesquisa suposições e hipóteses que possam encontrar eco in situ, em um corpus específico e reduzido, o que poderia levar-nos a construir generalizações ilusoriamente empíricas sobre os aspectos da idiossincrasia das comunidades de fala e sobre as variações linguísticas e socioculturais associadas à gestão interrelacional e a manifestação da cortesia.

Nesse sentido, a finalidade da criação e aplicação dos testes de hábitos sociais no presente capítulo é, a partir da comparação dos resultados obtidos nas duas etapas anteriores, o enfoque interdisciplinar e a análise do corpus, encontrar elementos comuns e regularidades entre as respostas dos informantes, a fim de estabelecer generalizações sobre as estratégias que ocorrem nos modos de formulação em determinados atos de fala. 


\subsection{Descrição do teste de hábitos sociais criado para o presente estudo}

A fim de descrever atitudes, pressupostos, premissas e valores culturais, inferências e crenças linguísticas ancoradas nos contextos sociais de ambas as línguas, como também precisar dados sobre as funções da cortesia no âmbito acadêmico e na dinâmica das relações sociais, criamos um teste de hábitos sociais que será apresentado a seguir, primeiramente na sua versão em português e, em seguida, em espanhol:

\section{QUESTIONÁRIO SOBRE HÁBITOS SOCIAIS E COMUNICATIVOS - 2015}

Este é um questionário sobre hábitos sociais e comunicativos em língua portuguesa (variedade de São Paulo). As suas respostas e os seus dados farão parte uma tese de doutorado e serão tratados de forma confidencial.

\begin{tabular}{|l|l|}
\hline \multicolumn{2}{|l|}{ Dados pessoais } \\
\hline Faixa etária & ( ) $17-25 \quad$ ( ) $26-55 \quad(\quad)+56$ \\
\hline Sexo & ( ) Mulher ( ) Homem \\
\hline $\begin{array}{l}\text { Estudos universitários } \\
\text { Informe que curso } \\
\text { universitário você estuda ou } \\
\text { estudou e em qual instituição. }\end{array}$ & $\begin{array}{l}\text { Curso em andamento: } \\
\text { Outro(s) curso(s): } \\
\text { Concluído(s) em: }\end{array}$ \\
\hline $\begin{array}{l}\text { Lugar de nascimento } \\
\text { Informe cidade e estado. }\end{array}$ & $\begin{array}{l}\text { Lugar de residência } \\
\text { Informe a região (leste, oeste, } \\
\text { norte e sul) onde você mora e } \\
\text { há quanto tempo você mora na } \\
\text { cidade }\end{array}$ \\
\hline $\begin{array}{l}\text { Profissão } \\
\text { Informe a sua atividade }\end{array}$ & Leste ( ) Oeste ( ) Norte ( ) Sul \\
\hline
\end{tabular}


profissional.

Idioma(s) - nível avançado

Você fala algum idioma

estrangeiro fluentemente?

Qual (quais).

\section{Parte I}

Responda as seguintes perguntas individualmente com a maior sinceridade possível.

1. Na universidade, numa conversação com colegas de classe, quando você precisa manifestar desacordo, há preocupações com a forma de expressar-se? Em caso afirmativo, quais são e por quê?

2. Nas conversações cotidianas entre colegas de classe, marque com um $X$ as opções que, segundo você, são as mais valorizadas pela maioria dos estudantes universitários na hora de comunicar-se:
a) ( ) Ser/parecer amigável;
b) ( ) Ser/parecer afetuoso;
c) ( ) Ser/parecer atencioso;
d) ( ) Ser/parecer alegre;
e) ( ) Ser/parecer cordial;
f) ( ) Ser/parecer generoso;
g) ( ) Ser/parecer sincero;
h) ( ) Ser/parecer verdadeiro;
i) ( ) Ser/parecer simpático;
j) ( ) Ser/ parecer justo;
k) ( ) Ser/ parecer educado;
1) ( ) Ser/ parecer inteligente; 


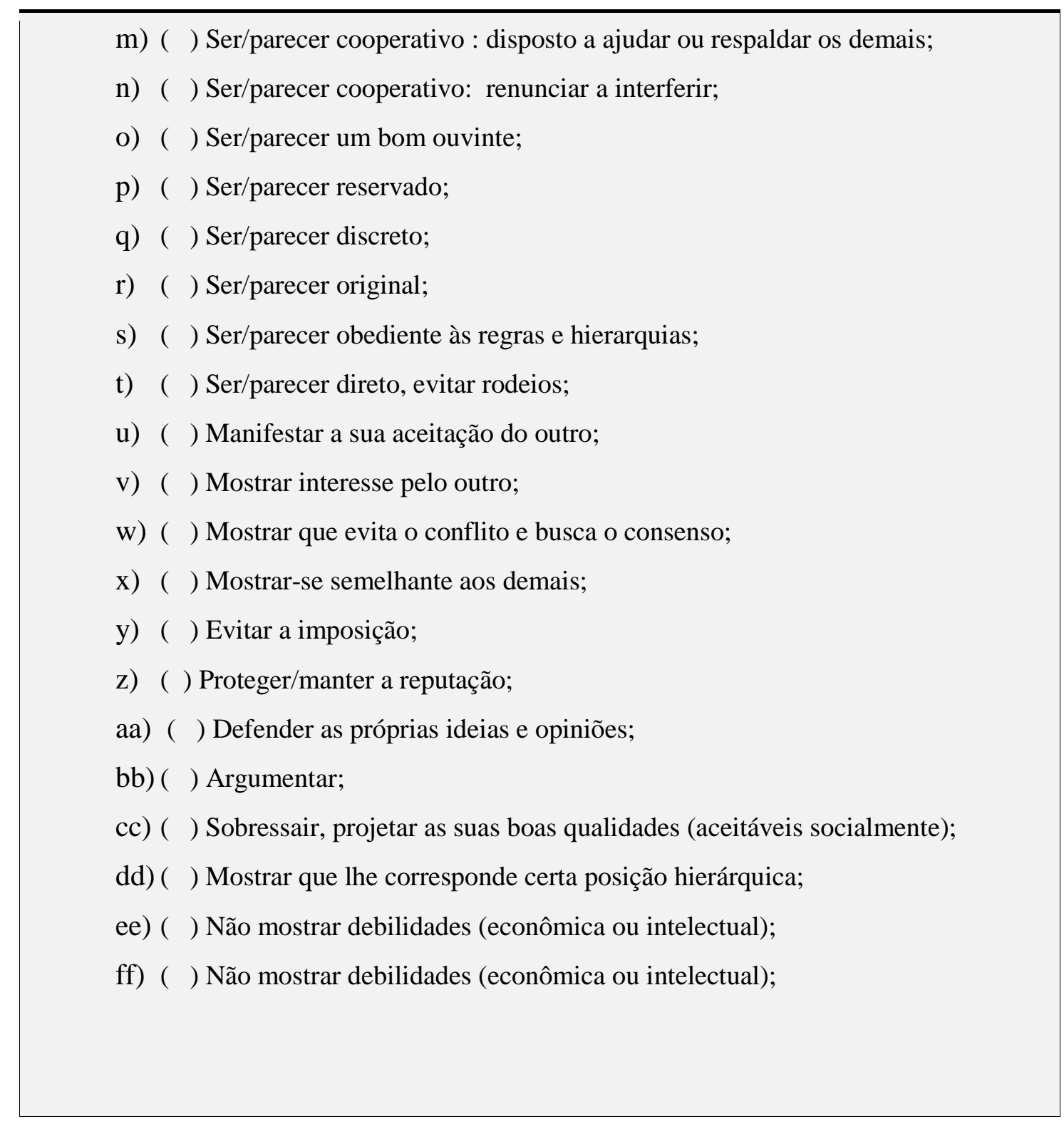

\section{Parte II}

Leia as seguintes situações e escreva literal e exatamente o que você diria em cada uma delas, em discurso direto, ou seja, reproduza a sua fala dentro de um contexto enunciativo. Pedimos que a sua resposta seja o mais natural possível. Se em alguma situação abaixo você optasse por não dizer nada, informe-nos e explique o motivo. 
3. Você está em uma reunião na universidade com mais quatro colegas de classe, preparando-se para um seminário.

a) Para este trabalho, o(a) professor(a) enviou algumas perguntas de pesquisa que devem ser respondidas. Você tem certeza de que a resposta a uma delas é "x", mas você percebeu que todos os demais desejam responder "y". Escreva aqui o que você" lhes diz.

b) Vocês cinco estão ensaiando a apresentação oral. Cada um deve falar por cinco minutos, segundo as instruções que receberam. Um de seus colegas, o João, já está se apresentando por sete minutos, está se estendendo e ainda faltam conteúdos e slides a serem comentados. Escreva aqui o que você diz ao João. 


\section{CUESTIONARIO SOBRE HÁBITOS SOCIALES Y COMUNICATIVOS}

Este es un cuestionario sobre hábitos sociales y comunicativos en español (variante Santiago de Chile). Sus respuestas y datos serán parte de una tesis doctoral y serán tratados de forma confidencial.

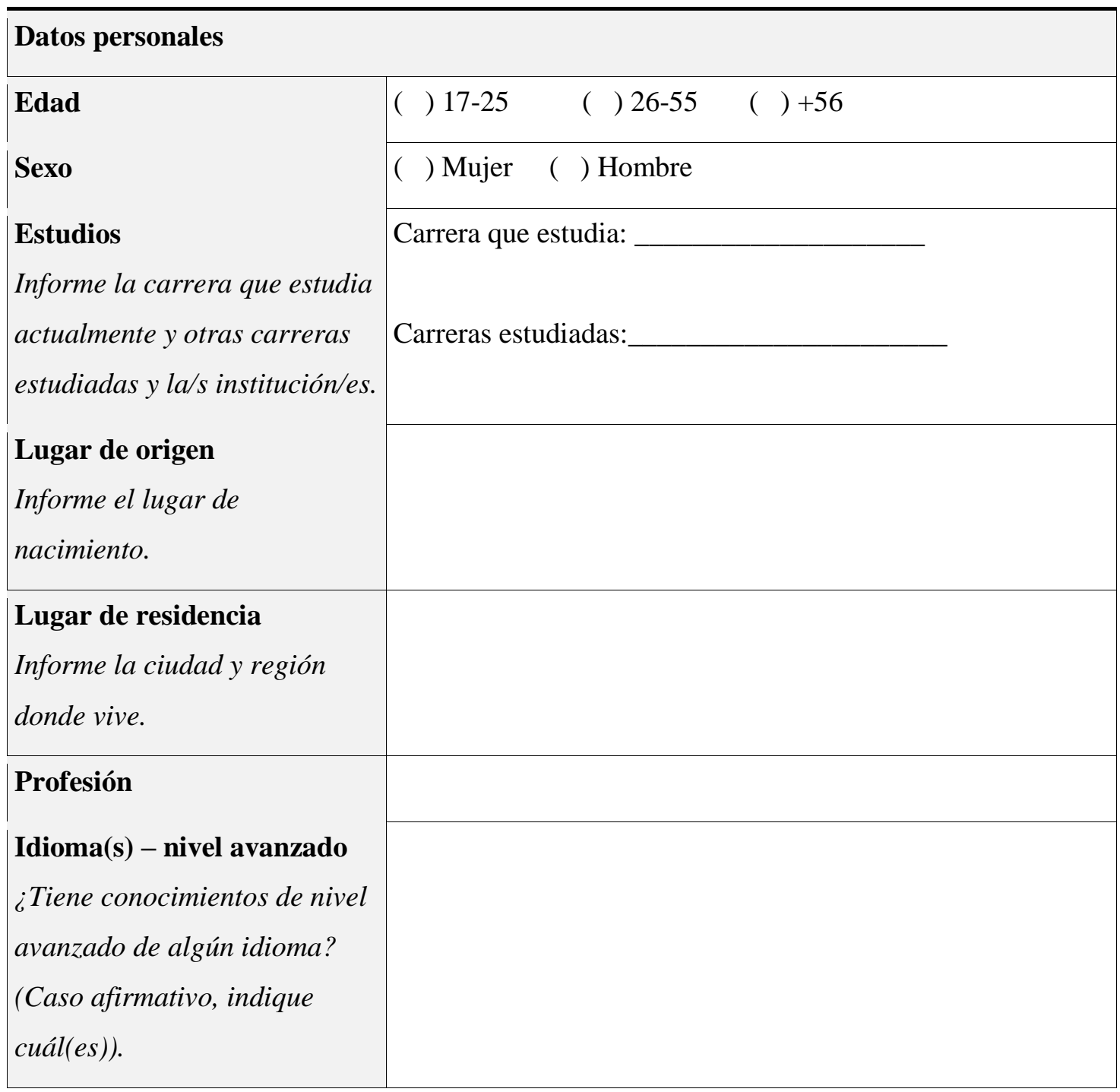

\section{Parte I}

Le ruego que responda a las siguientes preguntas individualmente con la mayor sinceridad posible.

1. En la universidad, en una conversación con compañeros de clase, cuando usted necesita expresar el desacuerdo, ¿hay preocupaciones acerca de la manera cómo enunciarlo? Caso 
afirmativo, indique cuál/cuáles son y por qué.

2. En conversaciones cotidianas entre compañeros de clase, marque con una $X$ las posiciones que, según su opinión, la mayoría de los estudiantes universitarios valoran en el momento de comunicarse:

a) ( ) Ser/parecer amigable;

b) ( ) Ser/parecer afectuoso;

c) ( ) Ser/parecer atento;

d) ( ) Ser/parecer alegre;

e) ( ) Ser/parecer cordial;

f) ( ) Ser/parecer generoso;

g) ( ) Ser/parecer sincero;

h) ( ) Ser/parecer verdadero;

i) ( ) Ser/parecer simpático;

j) ( ) Ser/ parecer justo;

k) ( ) Ser/ parecer educado;

1) ( ) Ser/ parecer inteligente;

m) ( ) Ser/parecer cooperativo: dispuesto a ayudar o respaldar a los demás;

n) ( ) Ser/parecer cooperativo: renunciar a interferir;

o) ( ) Ser/parecer buen oyente;

p) ( ) Ser/parecer reservado;

q) ( ) Ser/parecer discreto;

r) ( ) Ser/parecer original;

s) ( ) Ser/parecer obediente a las reglas y jerarquías;

t) ( ) Ser/parecer directo, evitar rodeos;

u) ( ) Manifestar que usted acepta al otro;

v) ( ) Mostrar interés por el otro;

w) ( ) Mostrar que usted evita el conflicto y busca el consenso; 

x) ( ) Mostrarse semejante a los demás;
y) ( ) Evitar la imposición;
z) ( ) Proteger/mantener la reputación;
aa) ( ) Defender las propias ideas y opiniones;
bb) ( ) Argumentar;
cc) ( ) Sobresalir, proyectar sus calidades (aceptadas socialmente);
dd) ( ) Mostrar que le corresponde cierta posición jerárquica;
ee) ( ) Mostrar conocimiento del tema en estudio/discusión;
ff) ( ) No mostrar debilidades (económica o intelectual);

\section{Parte II}

Lea las siguientes situaciones y escriba literal y exactamente qué dice usted en cada una, en estilo directo, es decir, reproduzca el habla dentro de un contexto enunciativo.

Le ruego que su respuesta sea lo más natural posible. Si en algún caso a continuación usted escogiera no decir nada, infórmenoslo y explique la razón.

3. Usted está en un encuentro en la universidad con cuatro compañeros de clase más, preparándose para una presentación oral.

a) Para este trabajo, el/la profesor/a les envió algunas preguntas de investigación que deben responder. Para usted, ciertamente la respuesta a una de estas preguntas es "x", pero ha notado que todos los demás desean responder " $y$ ". Escriba aquí qué les dice usted.

b) Sus compañero y usted, los cinco, están ensayando la presentación. Cada uno debe hablar por tan solo cinco minutos, según las instrucciones que recibieron. Uno de sus compañeros, Juan, ya está hablando por siete minutos y se está alargando porque aún le faltan contenidos y diapositivas de qué comentar. 
A primeira parte do teste traz perguntas relativas a comportamentos sociais e linguísticos em contextos específicos, e a segunda parte permite que 0 aluno escreva em discurso direto o que diria em determinadas situações que permitem a produção de atos assertivos ou diretivos. Como os testes foram distribuídos a estudantes da área de letras e tradução, mantivemos nas instruções conceitos metalinguísticos, o que nos poderia ajudar a evitar desvios de interpretação do que solicitamos.

Antes das questões, o teste permite que recolhamos dados sociológicos como idade, gênero, curso universitário, lugar de origem e de residência, profissão e idiomas dos quais o informante possui conhecimento em nível avançado, como forma de captar informação socieconômica, que foram descritas no Capítulo II deste trabalho.

\subsection{Discussão dos resultados do teste de hábitos sociais}

3.2.1. Considerações sobre os fenômenos de cortesia e a gestão das imagens a partir dos testes de hábitos sociais

Vamos apresentar e discutir os resultados de quarenta testes aplicados a informantes de Santiago do Chile e quarenta aplicados a informantes de São Paulo. 
As respostas foram classificadas de acordo com os objetivos desta pesquisa e entendemos que as informações que os informantes fornecem nos testes não necessariamente correspondem com o que realmente dizem em uma situação comunicativa, mas sim com o que consideram adequado dizer (Hernández Flores, 2002) segundo as valorações sociais.

A reprodução das respostas registradas por escrito nos testes será fiel aqui, mantendo-se inadequações de redação de todos os tipos. Ressaltamos também que a organização e classificação das respostas dos informantes será realizada mediante $o$ ato de fala nuclear, segundo a situação comunicativa de que faria parte, quando for o caso, uma vez que uma intervenção pode conter a realização de mais de um ato, além de seus modificadores internos e externos.

\section{Parte I - Pergunta 1}

Da primeira questão, da primeira parte do teste, sobre o comportamento cortês obtivemos os seguintes resultados:

\section{Tabela - 5 - Aplicação do Teste de Hábitos Sociais}

\section{Parte I - Pergunta 1 - São Paulo}

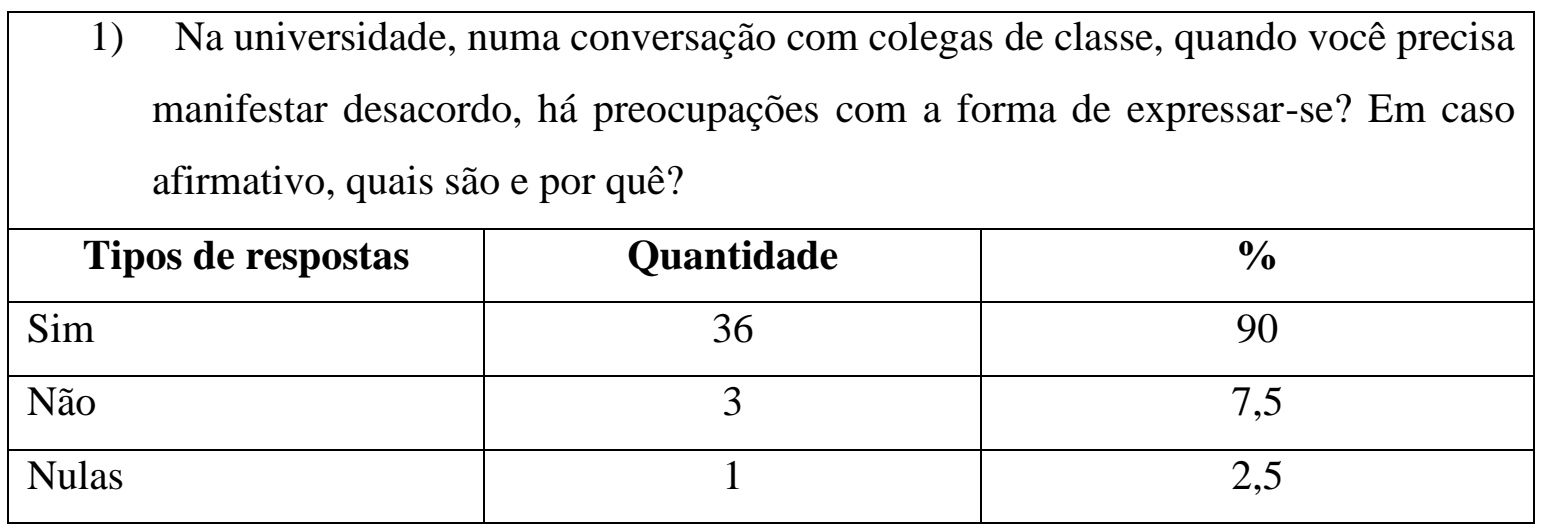




\section{Tabela 6 - Aplicação do Teste de Hábitos Sociais \\ Parte I - Pergunta 1- Santiago do Chile}

\begin{tabular}{|l|c|}
\hline 1) Na universidade, numa conversação com colegas de classe, quando você precisa \\
manifestar desacordo, há preocupações com a forma de expressar-se? Em caso \\
afirmativo, quais são e por quê?
\end{tabular}

Essa questão permite que o informante preste atenção no contexto universitário como um todo e não somente nos contextos de grupos de estudo, posto que nos interessa captar informações mais gerais.

Dos informantes brasileiros, 90\% demonstram algum tipo de preocupação quando precisam manifestar o desacordo no contexto universitário, e dos chilenos, $82,5 \%$ responderam o mesmo. Um questionário brasileiro não apresentou nenhuma resposta a essa questão, por isso foi anulada.

Recordemos que a asserção pode converter-se, durante a expressão do desacordo, em um ato de fala não cortês, porque não busca o benefício do interlocutor. Se o falante tenta convencer o seu ouvinte sobre a verdade de sua proposição, realiza um determinado tipo de ato assertivo, o ato argumentativo (Haverkate, 1994: 117), o que vimos acontecer inúmeras vezes no corpus, especialmente nos atos de correção.

Com essa primeira questão, podemos verificar quais são os aspectos que valorizam esses informantes quanto à cortesia assertiva, que consiste essencialmente em atenuar o conteúdo proposicional ou a força ilocutória da asserção. Consideramos também, nesta análise, que as dissenções constituem um tipo de interação não preferida, posto que ameaçam a imagem do interlocutor, por isso é comum a preocupação do falante em atenuá-las (Haverkate, 1994: 117).

Dos brasileiros, 7,5\% responderam que não existem preocupações no contexto universitário com a forma de expressar um desacordo; entre os 
chilenos a proporção foi maior, 17,5\% responderam negativamente, e suas justificativas foram:

\section{Aplicação do Teste de Hábitos Sociais \\ Parte I - Pergunta 1- São Paulo \\ Justificativas à resposta negativa}

(1) Não, não há.

(2) Não, pois se vem a ser necessário, é importante defender seu ponto de vista com solidez.

(3) Não, não falo o português padrão totalmente correto, mas não me importa tanto isso.

\section{Aplicação do Teste de Hábitos Sociais \\ Parte I - Pergunta 1- Santiago do Chile Justificativas à resposta negativa}

(1) No.

(2) No.

(3) Sencillamente lo digo.

(4) Me siento con la confianza suficiente para expresar un desacuerdo.

(5) No hay problemas.

(6) No considero que expresar un desacuerdo sea un problema, ya que no es una falta de respeto, de modo que basándose en opiniones con fundamentos para expresar el desacuerdo cada estudiante puede aprender mejor.

(7) Personalmente, no siento preocupaciones para demostrar mi desacuerdo a un compañero; para demostrárselo a un profesor, sí.

Um brasileiro que respondeu negativamente não escreveu justificativas, mas, nas demais respostas dos brasileiros, as explicações se diferem: em (2) 0 informante valoriza a defesa do ponto de vista "com solidez", do que se depreende uma preocupação autocêntrica na gestão das imagens; em (3), o informante não se preocupa com a gestão das imagens em uma situação comunicativa em que deva expressar o desacordo, todavia não podemos saber 
com certeza o que esse estudante considera "português padrão totalmente correto56". Devemos evidenciar que os informantes das respostas negativas (2) e (3), não são de São Paulo, nasceram no Paraná e em Pernambuco, respectivamente.

As respostas negativas chilenas também apontaram justificativas diversas, embora dois informantes não tenham escrito suas justificativas. Mas em geral, opinam que podem expressar o desacordo de maneira direta se há confiança e se, a partir disso, cada estudante pode aprender melhor, numa relação simétrica, entre alunos. A resposta (7) evidencia que numa relação assimétrica, entre aluno e professor, a preocupação quanto à maneira de expressar o desacordo aparece, devido às posições hierárquicas.

Abaixo expomos alguns exemplos das justificativas às respostas que continham um "sim". Constatamos que a maioria delas revelam estratégias afirmativas de cortesia, que visam a proteger e fortalecer ativamente a alo- ou autoimagem, a manutenção da harmonia social e a valorização do carácter relacional.

Estas respostas foram classificadas segundo evidenciam preocupações com a gestão de imagem alocêntrica ou autocêntrica. Alguns informantes responderam ao teste em primeira pessoa, mas a maioria explicitou os valores gerais do contexto em que estão inseridos, segundo suas próprias avaliações e experiências. Os exemplos das justificativas foram copiados aqui sem realizar correções na redação, para que não fossem contaminados pela nossa interpretação.

\section{Aplicação do Teste de Hábitos Sociais}

Parte I - Pergunta 1- São Paulo

Justificativas à resposta afirmativa - Exemplos

A) Empregar estratégias afirmativas das imagens de cordialidade, semelhança, cooperação e excelência e promover a autoimagem e a aloimagem

(1) No geral a preocupação é para não ofender a pessoa.

\footnotetext{
${ }^{56}$ Não consideramos que exista "português padrão totalmente correto", como disse este informante, mas sim respeitamos as diferenças diatópicas, diastráticas e diafásicas que uma língua possa apresentar, seja no discurso formal ou coloquial, no registro oral ou escrito.
} 
(2) Tento demonstrar que entendo e respeito a opinião diferente da minha.

(3) Tenho a preocupação de demonstrar que estou ouvindo meu colega e que, mesmo estando em desacordo, respeito a opinião dele.

(4) Mesmo que desacorde no assunto, não posso ser insensivel às experiências que as outras pessoas passaram, aprenderam.

(5) É necessário aceitar/ entender as opiniões.

(6) Porque tento não ser indelicado com a pessoa que eu discordo.

(7) De modo geral é sempre bom se expressar dentro do assunto, considerando a opinião dos colegas e argumentando sem ofender os demais.

\section{B) Empregar estratégias afirmativas e valorizar o carácter relacional}

(8) Procuro evitar conflitos com outras pessoas, devemos viver em harmonia.

(9) Preocupação em causar desarmonia, pois existem maneiras de se expressar cordialmente.

\section{C) Empregar estratégias alocêntricas e evitativas mediante comportamento} não preferido do interlocutor

(10) Pois algumas pessoas têm opiniões fortes e não aceitam que o outro não concorde com isto.

(11) Sim, há má recepção das diferenças de opiniões, pois algumas pessoas não sabem lidar com elas.

(12) Pois muitas pessoas têm dificuldade em ouvir críticas. É preciso dizê-las com palavras que diminuam sua gravidade e que deixem claro que não é algo pessoal. Por exemplo, um trabalho em grupo.

\section{D) Empregar estratégias afirmativas e autocêntricas}

(13) Muitas vezes uma palavra ou ideia pode ser mal interpretada.

(14) Não quero parecer desrespeitosa, grossa, tampouco intolerante ou autoritária.

(15) Dependendendo de como falo, posso parecer intransigente, presunçosa, pedante. Adjetivos não apreciados pelos colegas em geral e que acaba distanciando a convivência que se faz necessária.

(16) Demonstraria incerteza da minha parte para amenizar a impressão de desacordo.

(17) Tenho medo de parecer rude ou arrogante. Hesito, e sempre tento falar com delicadeza.

(18) Pois não quero parecer descortês ou deselegante.

(19) Preocupações em ser grosseiro e ou intolerante com a sua opinião, para que não haja um conflito posterior. 


\section{Aplicação do Teste de Hábitos Sociais \\ Parte I - Pergunta 1- Santiago do Chile \\ Justificativas à resposta afirmativa - Exemplos}

\section{A) Empregar estratégias afirmativas da imagem de excelência, proteger e fortalecer a autoimagem e a aloimagem}

(1) Me preocupo de ser amable, intentar no ofender y tal vez no atacar directamente el punto de vista de aquella persona, sino que exponer el mío.

(2) En instancias formales o protocolares, como una asamblea, es importante no ser ofensivo.

(3) Siempre se debe evitar el faltar el respeto a las demás personas con calificativos, etc.

(4) Hay preocupaciones en cuanto a pasar a llevar ${ }^{57}$ los valores o los puntos de vista de una persona. Uno no quiere insultar a alguien.

(5) Tratar de no hacer a la otra persona como si fuera tonta. No ser agresivo.

(6) Porque es importante que el otro no se sienta ofendido y así evitar una discusión "violenta", por eso hay que suavizar la forma de hablar.

(7) Tomando cierta distancia, intentando no hacer críticas personales sino de las ideas expresadas.

(8) Se trata de enunciar de forma que no parezca algo personal. También se hace hincapié en que quede claro el punto en que se está en desacordo.

(9) Pues dependiendo del tema, el desacuerdo hiere sensibilidades. Generalmente planteo que respeto la opinión divergente y que lo que pienso yo es puramente individual.

(10) Expresando el desacuerdo con respeto y sin argumentum ad hominem.

(11) Sí, mucha. Siento que acá, en Chile en general, es más importante cómo decir las cosas que lo que dirás en concreto. Por ejemplo, cuando estoy en desacuerdo con algo pongo una cara seria y pensativa e intento dar mi punto de vista amablemente, de forma clara y serena para que la otra persona no se sienta ofendida, ya que es muy común que la gente se apodere de sus opiniones y si alguien le dice que están mal, se sientan pasados a llevar. Entonces, si alguien le dice a otra persona que está mal, de una forma más directa y confiada, lo más posible es que la otra persona se sienta herida y se ponga a la defensiva.

(12) Normalmente las preocupaciones son que la otra persona se sienta

\footnotetext{
${ }^{57}$ No Chile, "pasar a llevar" significa “atropellar”, “no respetar” (Puga, 2013b: 122)
} 
atacada por nuestra manera de pensar, entonces, hay que elegir las palabras adecuadas al momento de demostrar desacuerdo para que el otro no piense que quieren provocar una pelea o que está siendo atacado sino que simplemente, se está demostrando un punto de vista diferente.

(13) Porque intento que la otra persona no se niegue a la posibilidad u opinión que estoy planteando y también intento evitar que con mi opinión se sienta ofendida o pasada a llevar.

\section{B) Empregar estratégias afirmativas e valorizar o carácter relacional}

(14) Si hay desacuerdo uno intenta negociar y bajarle el perfil ${ }^{58}$ para que no se vuelva más difícil.

(15) Es necesario modalizar o discurso, en especial, cuando hay desacuerdo. Por un lado es más persuasivo y por otro, mantiene buenas relaciones.

C) Empregar estratégias alocêntricas e evitativas mediante comportamento não preferido do interlocutor

(16) Ya que a veces se tiende a no aceptar los desacuerdos y tomarlos com un ataque.

(17) Por supuesto, hay personas que son extremadamente sensibles y exageradas. Creo que la mayoría de las veces a pesar de que las cosas se comunican de forma respetuosa, no es precisamente ese el factor que preocupa más a la hora de elegir como decir las cosas, sino que son las palabras en sí. Hay personas, sobre todo en Chile, que no admiten una crítica, creen que si uno no está con ellos está en su contra, se toman todo demasiado personal, por estar en desacuerdo te llegan a calificar de "conflictivo". Es importante la elección de palabras y el tono de voz para suavizar el mensaje, incluso la actitud, no derechamente apelativa.

\section{D) Empregar estratégias afirmativas e autocêntricas}

(18) Me interesa que no suene como "sabelotodo" ni como una demonstración a mi interlocutor. Eso con el vocabulario y el tono. Ello porque no me agrada pelear ni discutir.

(19) Por supuesto. Pues la idea no es discutir con el otro, sino hacerle comprender mi punto de vista. Se pueden decir muchas cosas de variadas maneras, por lo que la selección de las palabras y el tono que les dé será relevante en lo que el receptor perciba. Si soy grosero, por ejemplo, probablemente daré una imagen negativa de mi persona, cosa que no quiero.

(20) Hay miedo a la oposición de tu punto de vista por parte de tus compañeros/as.

58 "Bajar el perfil" significa "no ser visible", "pasar desapercebido". 
Tabela 7 - Aplicação do Teste de Hábitos Sociais

Parte I - Pergunta 1- São Paulo

Justificativas à resposta afirmativa - Proporções

\begin{tabular}{|c|c|c|}
\hline Tipo de justificativa & Quantidade & $\%$ \\
\hline $\begin{array}{l}\text { A) Empregar estratégias } \\
\text { afirmativas das imagens de } \\
\text { cordialidade, semelhança, } \\
\text { cooperação e excelência e } \\
\text { promover a autoimagem e a } \\
\text { aloimagem }\end{array}$ & 17 & 47,22 \\
\hline $\begin{array}{l}\text { B) Empregar estratégias } \\
\text { afirmativas e valorizar o carácter } \\
\text { relacional }\end{array}$ & 4 & 11,11 \\
\hline $\begin{array}{l}\text { C) Empregar estratégias } \\
\text { alocêntricas e evitativas mediante } \\
\text { comportamento não preferido do } \\
\text { interlocutor }\end{array}$ & 5 & 13,88 \\
\hline $\begin{array}{l}\text { D) Empregar estratégias } \\
\text { afirmativas e autocêntricas }\end{array}$ & 10 & 27,77 \\
\hline
\end{tabular}

Gráfico 1- Parte I - Pergunta 1- São Paulo

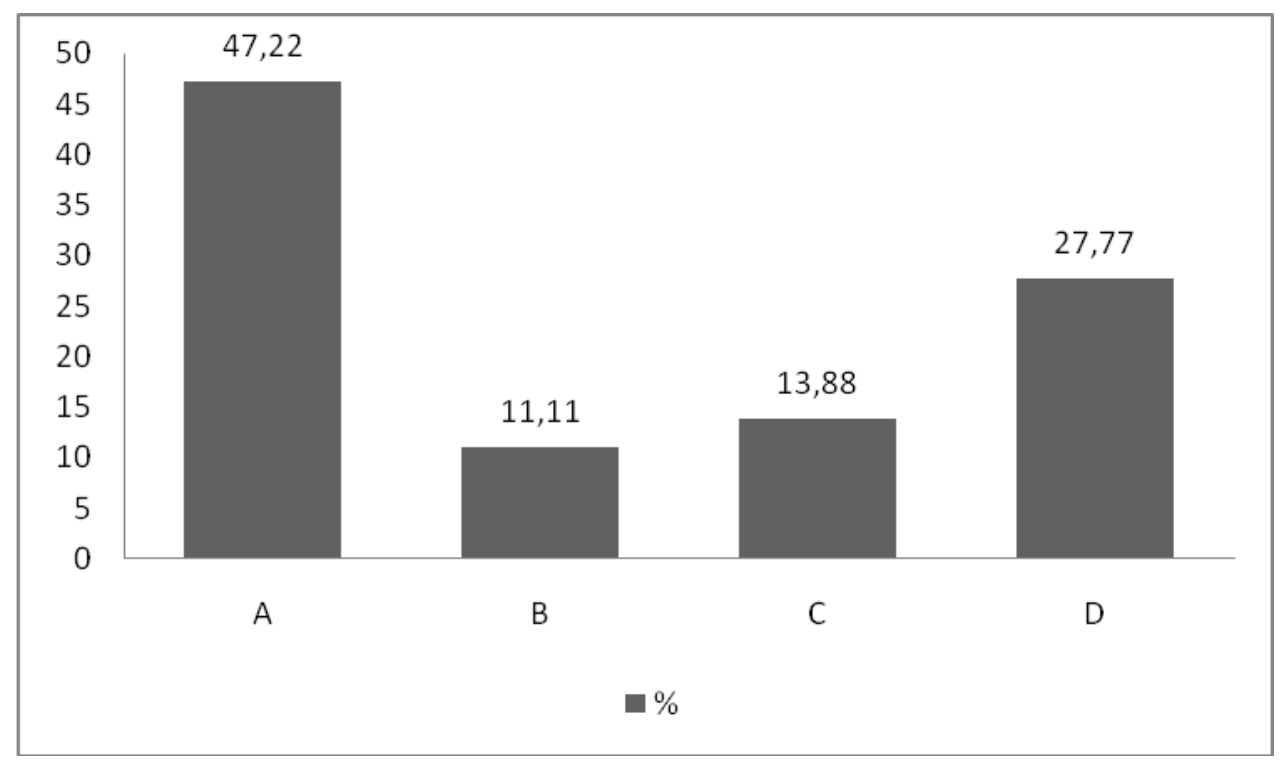

Tabela 8 - Aplicação do Teste de Hábitos Sociais 
Parte I - Pergunta 1- Santiago do Chile

Justificativas à resposta afirmativa - Proporções

\begin{tabular}{|l|c|c|}
\hline \multicolumn{1}{|c|}{ Tipo de justificativa } & Quantidade & \% \\
\hline $\begin{array}{l}\text { A) Empregar estratégias } \\
\text { afirmativas da imagem de } \\
\text { excelência, proteger e fortalecer a } \\
\text { autoimagem e a aloimagem }\end{array}$ & 21 & \\
\hline $\begin{array}{l}\text { B) Empregar estratégias } \\
\text { afirmativas valorizar o carácter } \\
\text { relacional }\end{array}$ & 2 & 6,06 \\
\hline $\begin{array}{l}\text { C) Empregar estratégias } \\
\text { alocêntricas e evitativas mediante } \\
\text { comportamento não preferido do } \\
\text { interlocutor }\end{array}$ & 3 & \\
\hline $\begin{array}{l}\text { D) Empregar estratégias } \\
\text { afirmativas e autocêntricas }\end{array}$ & & \\
\hline
\end{tabular}

Gráfico - Parte I - Pergunta 1- Santiago do Chile

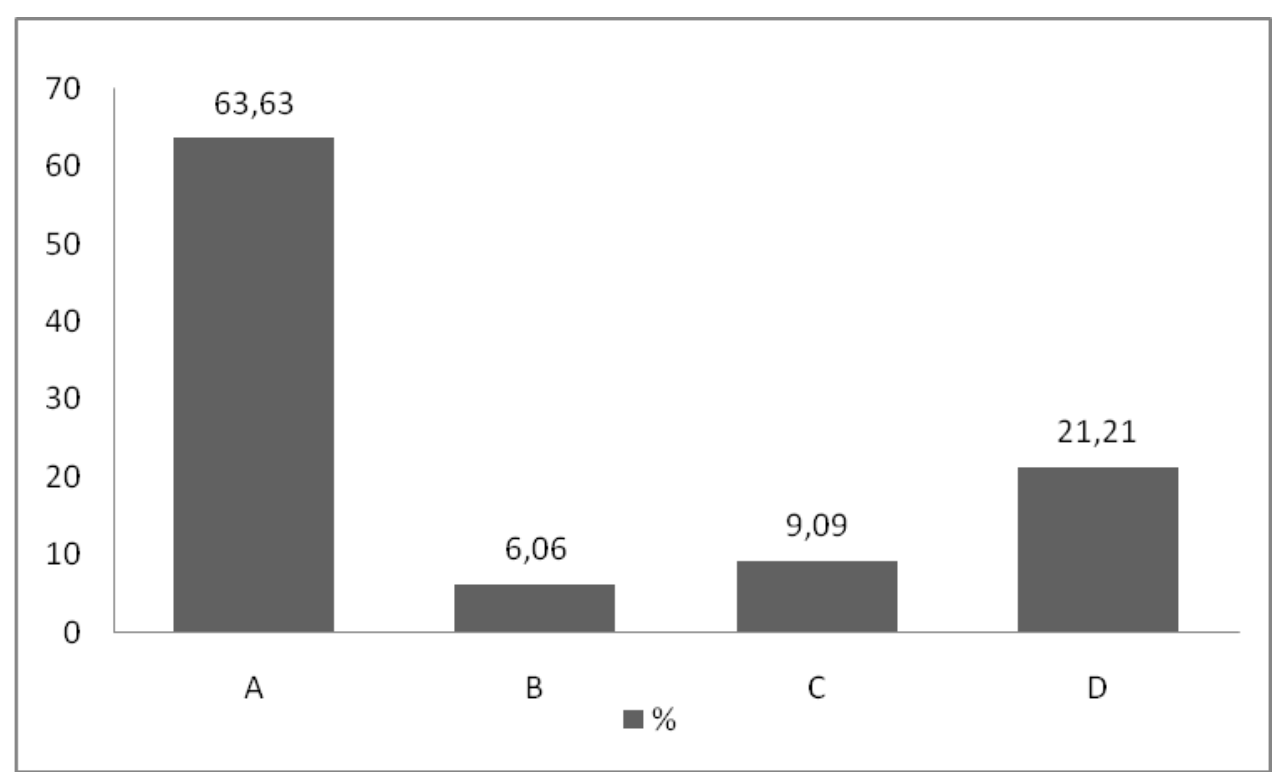

Prevaleceram as respostas que valorizam o emprego de estratégias afirmativas para proteger e fortalecer a autoimagem e a aloimagem tanto em São Paulo como em Santiago do Chile, porém, com significativas diferenças relativas às premissas culturais. 
Os informantes de São Paulo, 47,22\% dos que manifestam preocupar-se com a expressão do desacordo, são motivados pela valorização da imagem de cordialidade, que se identifica pela lógica relacional e uma maneira de atuar que valoriza a conciliação e a negociação. Assim, na universidade, os estudantes brasileiros tendem a fortalecer a imagem do ouvinte e suas intervenções, lembrando que ao fazê-lo, protegem suas próprias imagens, a fim de que sejam socialmente aceitos. E, para isso, buscam, conforme suas próprias palavras: "valorizar a fala do outro", "respeitar a opinião diferente", não ser "insensíveis às experiências das outras pessoas", "garantir que todos ouçam", "demonstrar respeito e humildade em sua fala" e "aceitar e entender as opiniões", para evitar 0 ataque às imagens dos interlocutores.

Nessa valorização das imagens públicas, os informantes buscam edificar o consenso através de posturas afiliativas. Na maioria das respostas analisadas, as palavras-chave que encontramos são o "respeito ao interlocutor" e a "ofensa", esses conceitos e ideias foram recorrentes nos testes analisados. Tal fato sinaliza que no contexto universitário desses informantes, o desacordo pode desencadear um conflito social e, assim, usualmente a preocupação é "não ofender" ao ouvinte, protegendo a sua face de excelência e salvaguardando as faces de semelhança e cooperação de falante e ouvinte.

Perguntamo-nos o que entendem por ofensa os 5 informantes brasileiros que mencionaram esse conceito, uma vez que os chilenos também 0 mencionaram, porém, aparentemente não de forma equivalente. Foram 4 os informantes chilenos que citaram palavras derivadas de "ofender" e, além disso, outros 10 deles mencionaram a preocupação por evitar que "la otra persona se sienta atacada" e "se sientan pasados a llevar", evitar insultos e "tratar de no hacer a la otra persona como si fuera tonta".

Por conseguinte, enquanto que os informantes brasileiros associam a ofensa ao desrespeito ao interlocutor e de suas ideias, grande parte dos chilenos vinculam a ofensa à ameaça direta e descortês do insulto ou a associam também à falta de respeito ao ouvinte.

Observamos, pois, que empregar estratégias afirmativas da imagem de excelência, proteger e fortalecer a autoimagem e a aloimagem fundamentaram as respostas de $63,63 \%$ dos informantes chilenos que exteriorizaram 
preocupações no momento de expressar um desacordo no contexto universitário.

Ressaltamos que em algumas respostas também lhes parece relevante a prosódia que evidencie a amabilidade, embora a prosódia não seja analisada empíricamente nesta pesquisa.

Algumas justificativas dos informantes chilenos representam um contraste com o que responderam os informantes brasileiros. Muitos chilenos valorizam a expressão clara de críticas ao conteúdo proposicional dos turnos dos interlocutores, desde que o interlocutor em si seja respeitado. De igual modo, constatamos a necessidade de marcar claramente com qual conteúdo exatamente não se está de acordo ou a necessidade de realçar que a opinião que se expressa é puramente individual.

Além disso, para a expressão do desacordo, o falante chileno pode expressar "una cara seria y pensativa" para enunciar seu "punto de vista amablemente, de forma clara y serena para que la otra persona no se sienta ofendida, enquanto que vimos que os informantes brasileiros, na análise do corpus tendem a sorrir ou rir nestes contextos.

Tantos chilenos como brasileiros, em proporções diferentes, 6,06\% e $11,11 \%$, respectivamente, exprimiram nas justificativas que se preocupam em empregar estratégias afirmativas e valorizar o carácter relacional durante a expressão do desacordo ("Procuro evitar conflitos com outras pessoas, devemos viver em harmonia"; "mantener buenas relaciones"). O fato de mais brasileiros explicitarem preocupação com a relação social, em comparação com os chilenos, pode ser reflexo da necessidade de proteção da imagem de cordialidade, que caracteriza a identidade do brasileiro pela coletividade e humanização.

Empregar estratégias alocêntricas e evitativas, mediante comportamento não preferido do interlocutor, compôs as justificativas de $13,88 \%$ dos brasileiros e $9,09 \%$ dos chilenos. Alguns informantes de São Paulo consideram que os interlocutores podem não saber aceitar descordâncias ("têm dificuldades em ouvir críticas"); e alguns informantes chilenos, segundo as suas premissas culturais, exprimiram que alguns interlocutores tendem "a no aceptar los desacuerdos y tomarlos com un ataque", pois "no admiten una crítica". 
A prevalência de preocupações com estratégias afirmativas e autocêntricas se deu em $27,77 \%$ das respostas dos brasileiros e em $21,21 \%$ das respostas dos chilenos. $\mathrm{Na}$ expressão do desacordo, os falantes buscam evitar que sejam mal interpretados; ou vistos como rudes, grosseiros, intolerantes, autoritários, arrogantes, indelicados e deselegantes, se citamos alguns adjetivos que registraram os informantes brasileiros nos questionários. Os chilenos, por sua vez, tendem a demonstrar que não Ihes agrada brigar ou discutir ou buscam manifestar que seu desejo não é exibir seu conhecimento. Ambos os grupos demonstram, portanto, quais comportamentos são valorizados em suas comunidades, que se diferem. Esses valores podem favorecer mais ou menos a ocorrência de recursos de atenuação.

Nesse sentido, verificamos que um informante brasileiro escreveu que: "demonstraria incerteza da minha parte para amenizar a impressão de desacordo", ou seja, ameaçaria a sua face de excelência, fingiria possuir menos conhecimento do que acredita, fortalecendo a sua imagem de cordialidade.

\section{Parte I - Pergunta 2}

Comentamos a seguir os contrastes e as correspondências encontradas na seleção de opções referentes ao comportamento cortês e à gestão da autoimagem.

Temos, na questão 2, 32 alternativas, na sua maioria, formuladas com o verbo "ser" unido ao "parecer" (ser/parecer justo, por exemplo), para que o informante pudesse selecioná-las segundo suas próprias crenças, embora, como analistas, consideramos que as características da imagem autocêntrica necessitam na verdade ser projetadas em uma sociedade ("parecer"), por um indivíduo. Para que seja aceito, este não necessariamente necessita possuir ("ser") esses atributos essencialmente. 
Tabela 9 - Aplicação do Teste de Hábitos Sociais

\section{Parte I - Pergunta 2- São Paulo e Santiago do Chile}

\section{Gestão da autoimagem - Proporções}

\begin{tabular}{|c|c|c|c|c|c|}
\hline \multirow[t]{3}{*}{ 2) } & \multicolumn{5}{|c|}{$\begin{array}{l}\text { Jas conversações cotidianas entre colegas de classe, marque com um } \mathrm{X} \text { as } \\
\text { pções que, segundo você, são as mais valorizadas pela maioria dos } \\
\text { studantes universitários na hora de comunicar-se: }\end{array}$} \\
\hline & \multirow[t]{2}{*}{ Opções } & \multicolumn{2}{|c|}{ Brasil } & \multicolumn{2}{|l|}{ Chile } \\
\hline & & Quantidade & $\%$ & Quantidade & $\%$ \\
\hline $\mathrm{A}$ & $\begin{array}{l}\text { ( ) Ser/parecer } \\
\text { amigável; }\end{array}$ & 32 & 80 & 35 & 87,5 \\
\hline $\mathrm{B}$ & $\begin{array}{l}\text { ( ) Ser/parecer } \\
\text { afetuoso; }\end{array}$ & 9 & 22,5 & 7 & 17,5 \\
\hline $\mathrm{C}$ & $\begin{array}{l}\text { ( ) Ser/parecer } \\
\text { atencioso; }\end{array}$ & 26 & 65 & 23 & 57,5 \\
\hline $\mathrm{D}$ & $\begin{array}{l}\text { ( ) Ser/parecer } \\
\text { alegre; }\end{array}$ & 17 & 42,5 & 12 & 30 \\
\hline $\mathrm{E}$ & $\begin{array}{l}\text { ( ) Ser/parecer } \\
\text { cordial; }\end{array}$ & 21 & 52,5 & 25 & 62,5 \\
\hline $\mathrm{F}$ & $\begin{array}{l}\text { ( ) Ser/parecer } \\
\text { generoso; }\end{array}$ & 8 & 20 & 11 & 27,5 \\
\hline $\mathrm{G}$ & $\begin{array}{l}\text { ( ) Ser/parecer } \\
\text { sincero; }\end{array}$ & 19 & 47,5 & 27 & 67,5 \\
\hline $\mathrm{H}$ & $\begin{array}{l}\text { ( ) Ser/parecer } \\
\text { verdadeiro; }\end{array}$ & 18 & 45 & 19 & 47,5 \\
\hline $\mathrm{I}$ & $\begin{array}{l}\text { ( ) Ser/parecer } \\
\text { simpático; }\end{array}$ & 26 & 65 & 24 & 60 \\
\hline $\bar{J}$ & $\begin{array}{l}\text { ( ) Ser/ parecer } \\
\text { justo; }\end{array}$ & 20 & 50 & 12 & 30 \\
\hline $\mathrm{K}$ & $\begin{array}{l}\text { ( ) Ser/ parecer } \\
\text { educado; }\end{array}$ & 29 & 72,5 & 19 & 47,5 \\
\hline $\mathrm{L}$ & $\begin{array}{l}\text { ( ) Ser/ parecer } \\
\text { inteligente; }\end{array}$ & 28 & 70 & 23 & 57,5 \\
\hline
\end{tabular}




\begin{tabular}{|c|c|c|c|c|c|}
\hline $\mathrm{M}$ & $\begin{array}{l}\text { ( ) Ser/parecer } \\
\text { cooperativo : } \\
\text { disposto a ajudar } \\
\text { ou respaldar os } \\
\text { demais; }\end{array}$ & 22 & 55 & 20 & 50 \\
\hline $\mathrm{N}$ & $\begin{array}{l}\text { ( ) Ser/parecer } \\
\text { cooperativo: } \\
\text { renunciar a } \\
\text { interferir; }\end{array}$ & 4 & 10 & 6 & 15 \\
\hline $\mathrm{O}$ & $\begin{array}{l}\text { ( ) Ser/parecer um } \\
\text { bom ouvinte; }\end{array}$ & 25 & 62,5 & 24 & 60 \\
\hline $\mathrm{P}$ & $\begin{array}{l}\text { ( ) Ser/parecer } \\
\text { reservado; }\end{array}$ & 2 & 5 & 1 & 2,5 \\
\hline $\mathrm{Q}$ & $\begin{array}{l}\text { ( ) Ser/parecer } \\
\text { discreto; }\end{array}$ & 4 & 10 & 5 & 12,5 \\
\hline $\mathrm{R}$ & $\begin{array}{l}\text { ( ) Ser/parecer } \\
\text { original; }\end{array}$ & 20 & 50 & 18 & 45 \\
\hline $\mathrm{S}$ & $\begin{array}{l}\text { ( ) Ser/parecer } \\
\text { obediente às regras } \\
\text { e hierarquias; }\end{array}$ & 2 & 5 & 3 & 7,5 \\
\hline $\mathrm{T}$ & $\begin{array}{l}\text { ( ) Ser/parecer } \\
\text { direto, evitar } \\
\text { rodeios; }\end{array}$ & 11 & 27,5 & 16 & 40 \\
\hline $\mathrm{U}$ & $\begin{array}{l}\text { ( ) Manifestar a } \\
\text { sua aceitação do } \\
\text { outro; }\end{array}$ & 20 & 50 & 17 & 42,5 \\
\hline $\mathrm{V}$ & $\begin{array}{l}\text { ( ) Mostrar } \\
\text { interesse pelo } \\
\text { outro; }\end{array}$ & 18 & 45 & 25 & 62,5 \\
\hline $\mathrm{W}$ & $\begin{array}{l}\text { ( ) Mostrar que } \\
\text { evita o conflito e } \\
\text { busca o consenso; }\end{array}$ & 14 & 35 & 14 & 35 \\
\hline $\mathrm{X}$ & ( ) Mostrar-se & 14 & 35 & 16 & 40 \\
\hline
\end{tabular}




\begin{tabular}{|c|c|c|c|c|c|}
\hline & $\begin{array}{l}\text { semelhante aos } \\
\text { demais; }\end{array}$ & & & & \\
\hline $\mathrm{Y}$ & $\begin{array}{l}\text { ( ) Evitar a } \\
\text { imposição; }\end{array}$ & 17 & 42,5 & 21 & 52,5 \\
\hline $\mathrm{Z}$ & $\begin{array}{l}(\mathrm{)} \\
\text { Proteger/manter a } \\
\text { reputação; }\end{array}$ & 4 & 10 & 10 & 25 \\
\hline $\mathrm{AA}$ & $\begin{array}{l}\text { ( ) Defender as } \\
\text { próprias ideias e } \\
\text { opiniões; }\end{array}$ & 21 & 52,5 & 17 & 42,5 \\
\hline $\mathrm{BB}$ & ( ) Argumentar; & 25 & 62,5 & 26 & 65 \\
\hline $\mathrm{CC}$ & $\begin{array}{l}\text { ( ) Sobressair, } \\
\text { projetar as suas } \\
\text { boas qualidades } \\
\text { (aceitáveis } \\
\text { socialmente); }\end{array}$ & 16 & 40 & 7 & 17,5 \\
\hline $\mathrm{DD}$ & $\begin{array}{l}\text { ( ) Mostrar que } \\
\text { lhe corresponde } \\
\text { certa posição } \\
\text { hierárquica; }\end{array}$ & 2 & 5 & 2 & 5 \\
\hline $\mathrm{EE}$ & $\begin{array}{l}\text { ( ) Não mostrar } \\
\text { debilidades } \\
\text { (econômica ou } \\
\text { intelectual); }\end{array}$ & 13 & 32,5 & 21 & 52,5 \\
\hline $\mathrm{FF}$ & $\begin{array}{l}\text { ( ) Ser/parecer } \\
\text { amigável; }\end{array}$ & 10 & 25 & 9 & 22,5 \\
\hline
\end{tabular}

Foram selecionadas em maior número pelos brasileiros as opções: a) ser/parecer amigável (80\%); c) ser/ parecer atencioso (65\%); i) ser/parecer simpático $(65 \%) ; \mathrm{k}$ ) ser/ parecer educado $(72,5 \%)$; I) ser/ parecer inteligente (70\%); o) ser/parecer um bom ouvinte (62,5); bb) argumentar (62,5\%). 
E os informantes de Santiago marcaram em maior quantidade as opções: a) ser/parecer amigável (87,5\%); e) ser/parecer cordial (62,5\%); g) ser/parecer sincero (67,5\%); i) ser/parecer simpático (60\%); o) ser/parecer um bom ouvinte $(60 \%)$; v) mostrar interesse pelo outro $(62,5 \%)$; bb) argumentar (65\%).

Grande parte das opções foram selecionadas por brasileiros e chilenos de maneira próxima, ou seja, quase todas as alternativas tiveram em média uma diferença de menos de dez pontos percentuais, exceto nove delas que se contrastam: d) ser/parecer alegre (42,5\% em São Paulo e 30\% em Santiago do Chile); j) ser/ parecer justo (50\% em São Paulo e 30\% em Santiago do Chile); k) ser/ parecer educado (72,5\% em São Paulo e 47,5\% em Santiago do Chile); I) ser/ parecer inteligente (70\% em São Paulo e 57,5\% em Santiago do Chile); t) ser/parecer direto (27\% em São Paulo e $40 \%$ em Santiago do Chile), evitar rodeios (27,5\% em São Paulo e 40\% em Santiago do Chile); v) mostrar interesse pelo outro ( $45 \%$ em São Paulo e 62,5\% em Santiago do Chile); z) proteger/manter a reputação (10\% em São Paulo e 25\% em Santiago do Chile); cc) sobressair, projetar as suas boas qualidades (aceitáveis socialmente) (40\% em São Paulo e 17,5\% em Santiago do Chile) e ee) não mostrar debilidades (econômica ou intelectual) (32,5\% em São Paulo e 52,5\% em Santiago do Chile).

A opção v) mostrar interesse pelo outro, foi mais selecionada por informantes chilenos do que por brasileiros, embora os traços das premissas culturais de nosso país pareça favorecer mais esta característica do que as descrições do contexto social chileno. Porém, através das respostas da questão 1, da parte I do teste, vimos que os chilenos no contexto acadêmico expressam preocupação com a proteção da aloimagem, de maneira distinta com relação aos brasileiros: ambos os grupos desmonstram utilizar estratégias afirmativas para proteger e fortalecer a auto- e a aloimagem, contudo os brasileiros parecem ser mais motivados pelo carácter relacional de seu contexto social e pelos direitos e necessidades do ouvinte, o que promove a sua autoimagem. Os chilenos, por sua vez, expressam em maior grau a valorização de estratégias que evitam o ataque pessoal ao ouvinte e atos descorteses, como $o$ insulto, 0 que também favorece a sua autoimagem. 


\section{Parte II - Pergunta 3 - a)}

A segunda parte propõe que os informantes escrevam em discurso direto o que dizem em situações específicas que possibilitam a produção de atos assertivos ou diretivos. Vejamos alguns resultados a seguir:

\section{Aplicação do Teste de Hábitos Sociais \\ Parte 2 - Pergunta 3 - a) - São Paulo}

\section{Ato assertivo - Exemplos}

3) Você está em uma reunião na universidade com mais quatro colegas de classe, preparando-se para um seminário.

a) Para este trabalho, o(a) professor(a) enviou algumas perguntas de pesquisa que devem ser respondidas. Você tem certeza de que a resposta a uma delas é "x", mas você percebeu que todos os demais desejam responder "y". Escreva aqui o você lhes diz

A) Empregar estratégias afirmativas da imagem de excelência, proteger e fortalecer a autoimagem e a aloimagem

(1)A resposta é a $x$, vocês não acham? Basta ler essa parte do texto.

(2) Eu acho que a resposta $x$ parece mais certa, por causa disso... E disso... O que vocês acham?

(3) Eu acho que a resposta é $x$. Por que vocês escolheram y?

(4) Eu acredito que a resposta é $x$. Por que vocês acreditam que é y?

(5) Vocês têm certeza que é y? Porque eu realmente acho que é $x$. Vamos rever essa questão juntos?

B) Valorização do carácter relacional

(6) Nós deveríamos discutir um pouco mais sobre essa resposta, se mesmo assim acharem que é y é a melhor, que vença a maioria.

(7) Bom, acredito que a resposta seja x, por que... Mas o que a maioria decidir nós colocamos.

(8) Oh, gente, eu tenho certeza que essa é a resposta certa, mas se vocês quiserem colocar essa, tudo bem.

(9) Gente, é que eu acho muito mesmo que é x, mas se vocês acham que é y, pode ser. 
(10) Se vocês todos concordam que a resposta é y, tudo bem, mas eu acredito que seja $x$. Será que nós poderíamos analisar a questão de novo? Se todo mundo continuar com a mesma opinião, coloquem o que a maioria escolheu.

\section{C) Acentuar a modestia ou expressar incerteza}

(11) Mas gente, eu vi em z que a resposta mais provável é x... Não sei, posso ter escutado errado, mas quase certeza que éx. Vou procurar aqui...

(12) Bem, pessoal, eu acho melhor nós vermos de novo a resposta $x$, se acharem novamente que não condiz com o trabalho, eu concordo em responder y.

(13) Pessoal, eu não sei se sou eu que estou errado, mas vocês colocaram uma alternativa diferente da minha. Por quê? O que vocês acham?

(14) Eu não consigo entender o porque de y. Vocês podem me explicar, porque tenho certeza que é $x$, porque isso... (argumentos)

(15) Gente, talvez a resposta y não seja bem, a correta, porque... Já pensaram nisso? Talvez eu esteja errado, claro. Mas o que vocês acham disso?

(16) Gente, eu acho que errei essa resposta. Como que vocês chegaram nessa conclusão?

(17) Acho que éx, mas talvez eu esteja errado.

\section{D) Empregar estratégias afirmativas e autocêntricas}

(18) Isso está errado. Vamos dar uma olhada na bibliografia novamente? Talvez vocês deixaram passar alguma coisa.

(19) Pessoal, eu acho que a resposta é x, pois...

\section{Tabela 10 - Aplicação do Teste de Hábitos Sociais}

Parte 2 - Pergunta 3 - a) - São Paulo

Ato assertivo - Proporções

\begin{tabular}{|l|c|c|}
\hline \multicolumn{1}{|c|}{ Tipo de realização } & Quantidade & \% \\
\hline $\begin{array}{l}\text { A) Empregar estratégias } \\
\text { afirmativas da imagem de } \\
\text { excelência, proteger e fortalecer a } \\
\text { autoimagem e a aloimagem }\end{array}$ & 21 & 52,5 \\
\hline $\begin{array}{l}\text { C) Valorização do carácter } \\
\text { relacional }\end{array}$ & 8 & 20 \\
\hline $\begin{array}{l}\text { D) Acentuar a modéstia ou } \\
\text { expressar incerteza }\end{array}$ & 9 & 22,5 \\
\hline E) Empregar estratégias & 2 & 5 \\
\hline
\end{tabular}


Gráfico 3 -Parte 2 - Pergunta 3 - a) - São Paulo

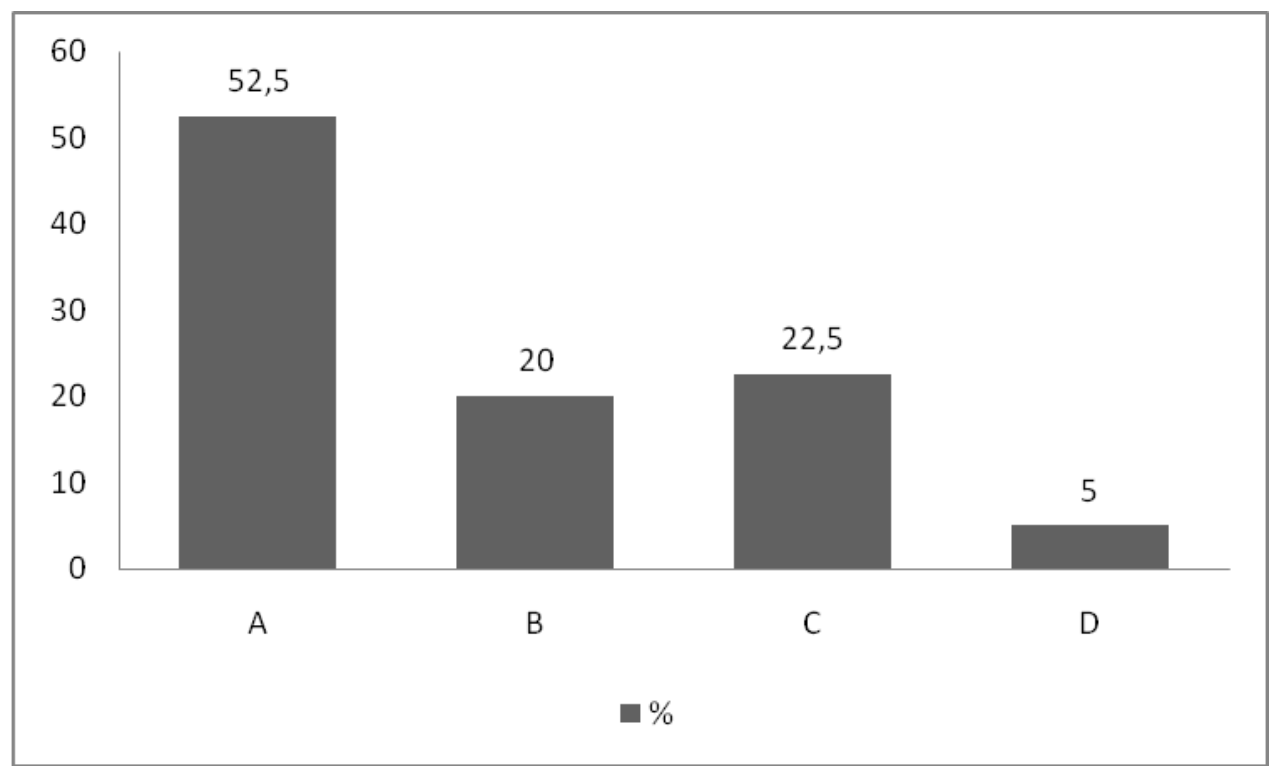

Aplicação do Teste de Hábitos Sociais

Parte 2 - Pergunta 3 - a) - Santiago do Chile

Ato assertivo - Exemplos

A) Empregar estratégias afirmativas da imagem de excelência, proteger e fortalecer a autoimagem e a aloimagem

(1) Según yo, creo que la respuesta a esta pregunta es $Y$, pero veo que ustedes no están de acuerdo. ¿Por qué creen que es la otra respuesta? ¿En qué se basan para decir eso? Denme sus opiniones...

(2)A mi juicio, deberíamos considerar estos otros elementos, porque ellos motivarían contestar X y no Y. De hecho, yo quisiera contestar X.

(3) Estoy segura que la respuesta es $X$, ¿Por qué creen que es $Y$ ?

(4) Chiquillos, ¿están seguros de que es y? Yo creo que es $x$.

(5) La respuesta según yo es $X$. ¿Qué opinan ustedes?

(6) Yo creo que la respuesta a esta pregunta es $X$, y la razón sería esta. ¿ustedes qué creen?

(7) Para mí, la respuesta sería X porque..., no sé, ¿Qué opinan ustedes?

B) Valorização do carácter relacional

(8) Pienso que quizá deberíamos considerar o revisar de nuevo esto. Para mí es $X$, pero si ustedes piensan que es $Y$ podemos dejarlo así. 
(9) Chicos, ¿podemos llegar a un consenso y generar una o dos respuestas que represente el pensar común del equipo?

\section{C) Acentuar a modéstia ou expressar incerteza}

(10) Yo creo que es X, porque Y..., me da miedo porque tal vez me equivoqué. ¿Por qué pusieron Y? -Luego de mucho pensarlo la dejaría igual-

(11) Yo creo que la respuesta es X porque eso fue lo que entendí en la materia en clase, pero, la verdad no estoy muy segura.

(12) Disculpen, estoy muy loca, o yo entendí que la respuesta es $x$.

D) Empregar estratégias afirmativas e autocêntricas

(13) Hueón, ¿cómo va a ser x?, si es (argumento). Yo creo que es eso.

(14) Yo creo que la respuesta acá es $X$, por(razones)

(15) Me parece que es X...

(16) No estoy de acuerdo, yo creo que es...

Tabela 11 - Aplicação do Teste de Hábitos Sociais

Parte 2 - Pergunta 3 - a) - Santiago do Chile

Ato assertivo - Proporções

\begin{tabular}{|l|c|c|}
\hline \multicolumn{1}{|c|}{ Tipo de realização } & Quantidade & \% \\
\hline $\begin{array}{l}\text { A) Empregar estratégias } \\
\text { afirmativas da imagem de } \\
\text { excelência, proteger e fortalecer a } \\
\text { autoimagem e a aloimagem }\end{array}$ & 19 & $47,5 \%$ \\
\hline $\begin{array}{l}\text { B) Valorização do carácter } \\
\text { relacional }\end{array}$ & 4 & 10 \\
\hline $\begin{array}{l}\text { C) Acentuar a modéstia ou } \\
\text { expressar incerteza }\end{array}$ & 5 & 12,5 \\
\hline $\begin{array}{l}\text { D) Empregar estratégias } \\
\text { afirmativas e autocêntricas }\end{array}$ & 12 & 30 \\
\hline
\end{tabular}


Gráfico 4 - Parte 2 - Pergunta 3 - a) - Santiago do Chile

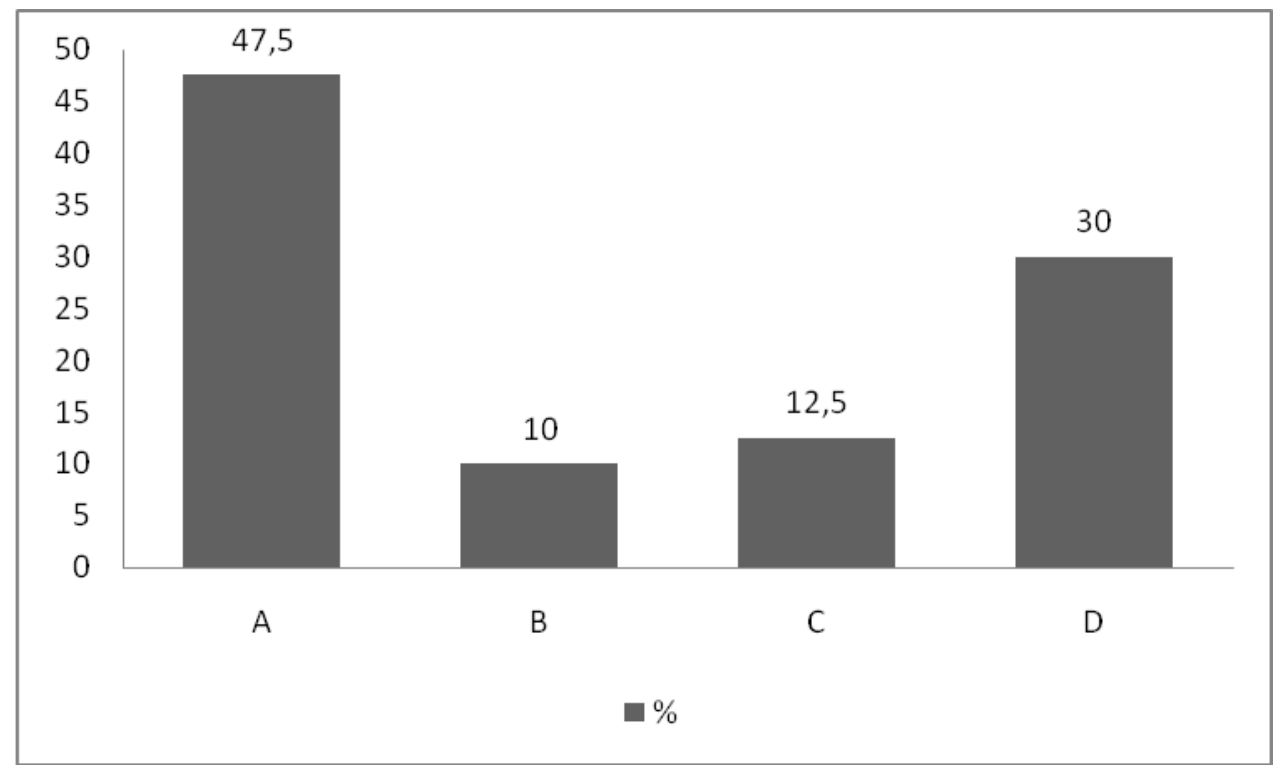

Classificamos as respostas no item "A) Empregar estratégias afirmativas da imagem de excelência, proteger e fortalecer a autoimagem e a aloimagem", aquelas que possuem mais de um recurso de atenuação e/ou propõem uma pergunta ao ouvinte, valorizando a sua opinião. As respostas dos informantes classificadas como "E) Empregar estratégias afirmativas e autocêntricas", também pode possuir atenuação", também podem apresentar atenuação, mas somente um recurso.

Em ambas as comunidades de fala, em maior número (52,5\% nos testes de São Paulo e em $47,5 \%$ nos testes de Santiago do Chile), foram escritas respostas que corresponderiam a intervenções que possuem elementos relativizadores que debiltam a força argumentativa com relação à certeza do enunciado, são recursos de atenuação ("acredito que", "eu acho que", "Según yo, creo que", "A mi juicio, deberíamos") que podem prevenir ou reparar, são escudos protetores da imagem de excelência dos ouvintes e da própria.

Essas estratégias podem ser alocêntricas, portanto, pois podem valorizar a opinião do ouvinte. Assim, são frequentes intervenções encontradas nos testes que, embora enunciem a opinião do falante, são corteses na medida em que são orientadas aos interesses do interlocutor, dando-lhe a oportunidade de opinar, promovendo a aloimagem e desejos do outro ("A resposta é a $x$, vocês não acham?", “QQué opinan ustedes? "). 
A busca da harmonia social, da democratização e a valorização do carácter relacional se notaem $20 \%$ dos testes brasileiros, nesta questão, e em $10 \%$ dos chilenos ("Gente, é que eu acho muito mesmo que é $x$, mas se vocês acham que é $y$, pode ser", "Para mí es $X$, pero si ustedes piensan que es $Y$ podemos dejarlo asi"). Vale ressaltar que uma das respostas chilenas, neste caso, busca o consenso a partir da consideração da opinião do falante ("Chicos, ¿podemos llegar a un consenso y generar una o dos respuestas que represente el pensar común del equipo?"), enquanto que os brasileiros se abstêm ou desistem de emitir a dissenção.

A estratégia de mitigar a própria opinião para diminuir a dissenção ocorreu em $20 \%$ dos testes de São Paulo e em 12,5\% dos testes chilenos, com a tática de acentuar a modéstia, fingindo falta de conhecimento ou expressando incerteza ("Posso ter escutado errado", "Eu não consigo entender o porque de y","Talvez eu esteja errado"," tal vez me equivoqué", "no estoy muy segura"). Essas estratégias também são afirmativas de cortesia construtiva.

O último tipo de realizações que encontramos foi o emprego de estratégias afirmativas e autocêntricas, que foi apontado em $5 \%$ dos testes paulistanos e $30 \%$ dos chilenos. Diferentemente do primeiro grupo de táticas que analisamos, estas intervenções não dão voz ao ouvinte. O falante expressa a sua opinião, atenuando, muitas vezes, a força ilocutória do ato ou a si mesmo ("No estoy de acuerdo, yo creo que es", "Pessoal, eu acho que a resposta é $x$, pois"); e pode, muitas vezes, ameaçar a face do ouvinte, oferencendo ou não reparos ("vocês deixaram passar alguma coisa", “cómo va a ser $x$ ? "). 


\section{Parte II - Pergunta 3 - b)}

Esta questão possibilita a produção de um ato exortativo. Vejamos o que produziram os informantes:

\section{Aplicação do Teste de Hábitos Sociais \\ Parte 2 - Pergunta 3 - b) - São Paulo \\ Ato exortativo - Exemplos}

3) Você está em uma reunião na universidade com mais quatro colegas de classe, preparando-se para um seminário.

b) Vocês cinco estão ensaiando a apresentação oral. Cada um deve falar por cinco minutos, segundo as instruções que receberam. Um de seus colegas, o João, já está se apresentando por sete minutos e ainda faltam conteúdos e slides a serem comentados. Escreva aqui o que você diz ao João.

\section{A) O ato é realizado diretamente sem mostrar cortesia}

(1) João, vai rápido.

B) O ato é realizado com estratégias autocêntricas

(2) João, ainda tem outras pessoas, se você puder resumir...

(3) João, você precisa diminuir o seu tempo de fala para que todos possam falar.

\section{C) $\mathbf{O}$ ato é realizado com estratégias alocêntricas}

(4) João, acho que você está falando demais, hein?(risos) Deixa a gente falar também, poxa! (tom de brincadeira)

(5) João, o tempo já deu.

(6) João, desculpe, mas se puder concluir sua ideia, porque senão não restará tempo para falar.

(7) João, já se passaram sete minutos. Acho melhor a gente tentar reduzir o tempo de fala para não ultrapassar.

(8) Você pode ser mais breve, por favor? Ainda tem muitos slides para comentar.

(9) João, querido, tenta encerrar sua fala nos próximos minutos, por favor. O tempo está ficando curto e ainda temos coisas para expor. 
(10) João, será que você consegue ir mais rápido na apresentação ou diminuir o conteúdo? Ficou muito legal a sua parte, mas a professora quer que todos falemos cinco minutos. O que você acha?

(11) João, tá ótimo, mas toma cuidado com o tempo, ok?

(12) Falo baixinho pra ele:

(13) - João, já passou o tempo, tem como dar só uma aceleradinha?

(14) João, conclui aí, por favor, ainda faltam os outros (rs. $)^{59}$

(15) João, acho melhor redistribuirmos os temas e falas para cada um, para que cada integrante fale num mesmo período de tempo, ou seja, por cinco minutos.

D) $O$ ato não é realizado verbalmente

(16) Não digo nada. Só escrevo em um papel que o tempo dele acabou e dou-lhe.

(17) Prefiro não interferir na apresentação dele.

(18) Dou um discreto cutucão para que termine logo, rs.

(19) Não digo nada, tento atestá-lo com gestos ou olhares.

Tabela 12 - Aplicação do Teste de Hábitos Sociais

Parte II - Pergunta 3 - b) - São Paulo

Ato exortativo - Proporções

\begin{tabular}{|c|c|c|}
\hline Tipo de realização & Quantidade & $\%$ \\
\hline $\begin{array}{l}\text { A) O ato é realizado diretamente sem } \\
\text { mostrar cortesia }\end{array}$ & 1 & 2,5 \\
\hline $\begin{array}{l}\text { B) O ato é realizado com estratégias } \\
\text { autocêntricas }\end{array}$ & 5 & 12,5 \\
\hline C) O ato é realizado com estratégias \\
alocêntricas
\end{tabular}

\footnotetext{
${ }^{59}$ Este informante escreveu "rs." que é a abreviação de "risos", na linguagem da internet.
} 


\section{Gráfico 5 - Parte II - Pergunta 3 - b) - São Paulo}

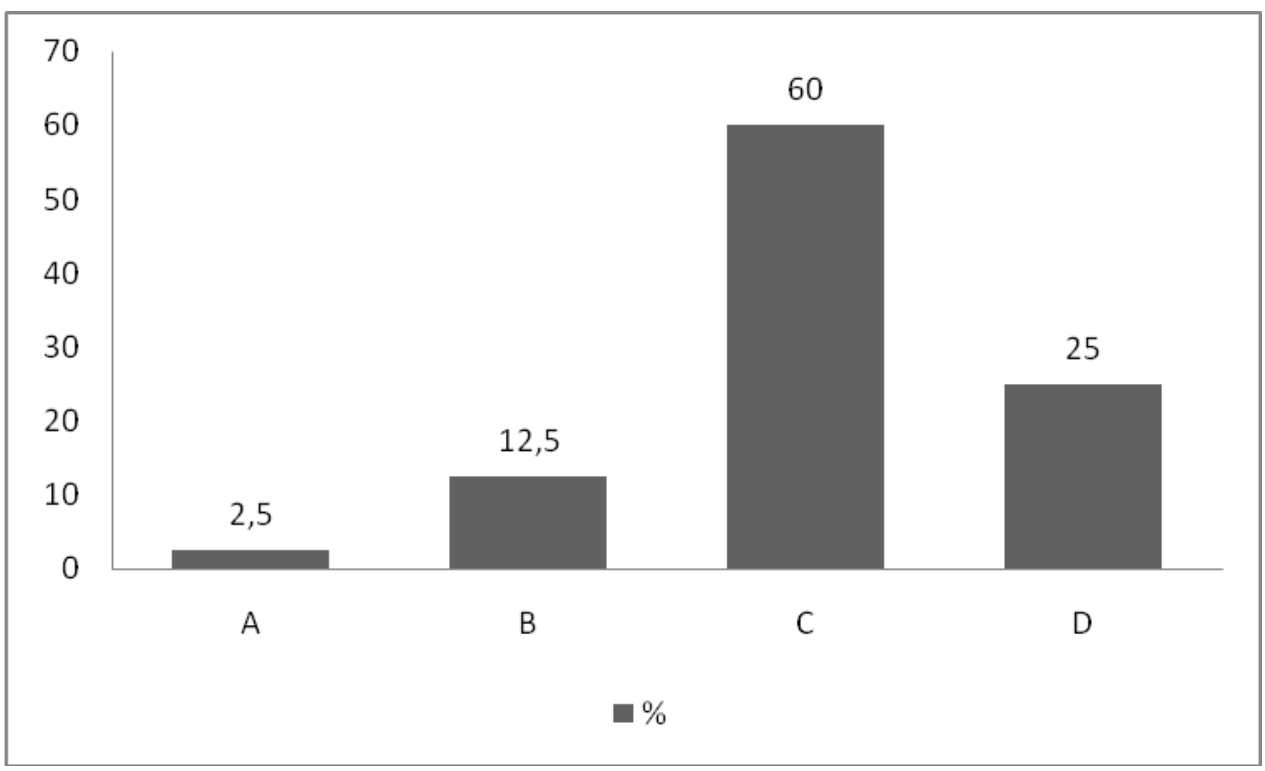

Aplicação do Teste de Hábitos Sociais

\section{Parte II - Pergunta 3 - b) - Santiago do Chile}

\section{Ato exortativo - Exemplos}

A) O ato é realizado diretamente sem mostrar cortesia

(1) Ya, ;basta! Nadie te está oyendo. Nos da mucha lata.

(2) Debes acortar la presentación. Así no vamos a alcanzar hablar todos.

(3) Mira, o lo hacís más corto o yo te corto. Vo’ decidí.

(4) Ya, para, te pasaste del tiempo.

(5) Hueón, para, te estai pasando del tiempo.

(6) Ya, sintetiza un poco que faltan los demás.

(7) Hey, acuérdate mantenerte dentro del tiempo.

(8) ¡Puta Juan! Dijimos que eran solo 5 minutos cada uno, ¿por qué te alargaste tanto? ¡Para la otra, haz caso!

B) $O$ ato é realizado com estratégias autocêntricas

(1) Juan, Juan, hey, espera um poco. Cada uno tiene cinco minutos y tú llevas siete, sin terminar todavía. Revisa tu parte, o revisémosla entre todos, para hacer una buena síntesis que quepa en cinco minutos. Si no, vamos a salir perjudicados.

(2) Juan, la profesora nos dijo que sólo deben ser cinco minutos y tu ya vas casi para los siete.Es mejor que todos ocupemos la misma cantidad de tiempo, debe ser 
equitativo, además la profesora nos dio un tiempo límite y nos puede bajar la nota por no seguir sus indicaciones.

(3) Juan, vas a tener o que hablar más rápido o que pensar alguna forma en que no te alargues porque todos tenemos que hablar la misma cantidad y si tú te alargas los demás vamos a tener menos tiempo y tendremos que explicar rápido y posiblemente mal nuestra parte, así que intenta grabarte o nosotros te cortamos cuando lleves 5 minutos y así lo vas regulando. Así, en el momento de la presentación ya va a estar practicado y no tendremos ese problema de tiempo.

(4) Juan, vas a tener que resumir el contenido de tu parte porque te estás alargando demasiado y eso hace que nos bajen la nota $\circledast^{00}$.

\section{C) $\mathrm{O}$ ato é realizado com estratégias alocêntricas}

(5) Oye, ya po, tenemos que avanzar.

(6) Ya po, hueón, se acaba el tiempo.

(7) "Juanuchoooooo, llevas como siete horas hablando, jajaja. ¿Por qué no intentas resumir un poquito más las cosas? Es que la idea es que quede más o menos claro no más, como la profe pidió que fuesen cinco minutos no más, no sé, quizás te bajen o nos bajen la nota por eso ${ }^{\circ 1}$ ¿O no te importa nada? jaja"

(8) Parece que tu parte es más larga.

(9) Disculpa, Juan, pero te estás demorando mucho tiempo.

(10) Juan, tu parte está excelente, ipero un poco larga! Recuerda que debemos hablar solo cinco minutos.

(11) Juan, está bien lo que estás diciendo, pero deben ser solo cinco minutos... así que debes tratar de acortarlo.

(12) Juan, está muy larga tu presentación. ¿Por qué no la acortas? O puedes dividir tu información con nosotros.

(13) Juan, es importante tener ojo con el tiempo. Hay que ser más sintético para lograr los cinco minutos cada uno.

(14) Juan, trata de acortar tu parte un poquito porque te estás pasando o acuérdate que pueden ser máximo cinco minutos.

(15) Juan, hay que ser breve. Por fa, organicemos mejor lo que dirás.

(16) Juan, es necesario que puedas acortar tu presentación pues nos corresponde un tiempo a cada uno. Debes buscar la forma de sintetizar en 5 minutos y asi respetar a los demás.

${ }^{60}$ Este informante utilizou um símbolo comumente utilizado na linguagem de internet para denotar tristeza. ${ }^{61}$ Idem. 


\section{D) O ato não é realizado verbalmente}

(17) Intento hacer a partir de señas discretas que se apure. Pero no interrumpiría la presentación.

(18) No le digo nada pero le señalo que está fuera del tiempo con una señal de ver "el reloj".

(19) No le diría nada, porque interrumpir la presentación de mi compañero le faltaría el respeto y puede afectar la continuidad de la presentación completa (pues puede que quede información sin concluir) En cambio, trataría de hacer señales y gestos para captar su atención y tratar de decirle que resuma y termine en breve su exposición.

\section{Tabela 13 - Aplicação do Teste de Hábitos Sociais \\ Parte II - Pergunta 3 - b) - Santiago do Chile \\ Ato exortativo - Proporções}

\begin{tabular}{|c|c|c|}
\hline Tipo de realização & Quantidade & \% \\
\hline $\begin{array}{l}\text { A) O ato é realizado diretamente sem } \\
\text { mostrar cortesia }\end{array}$ & 12 & 30 \\
\hline B) O ato é realizado com estratégias \\
autocêntricas
\end{tabular}

\section{Gráfico 6 - Parte II - Pergunta 3 - b) - Santiago do Chile}

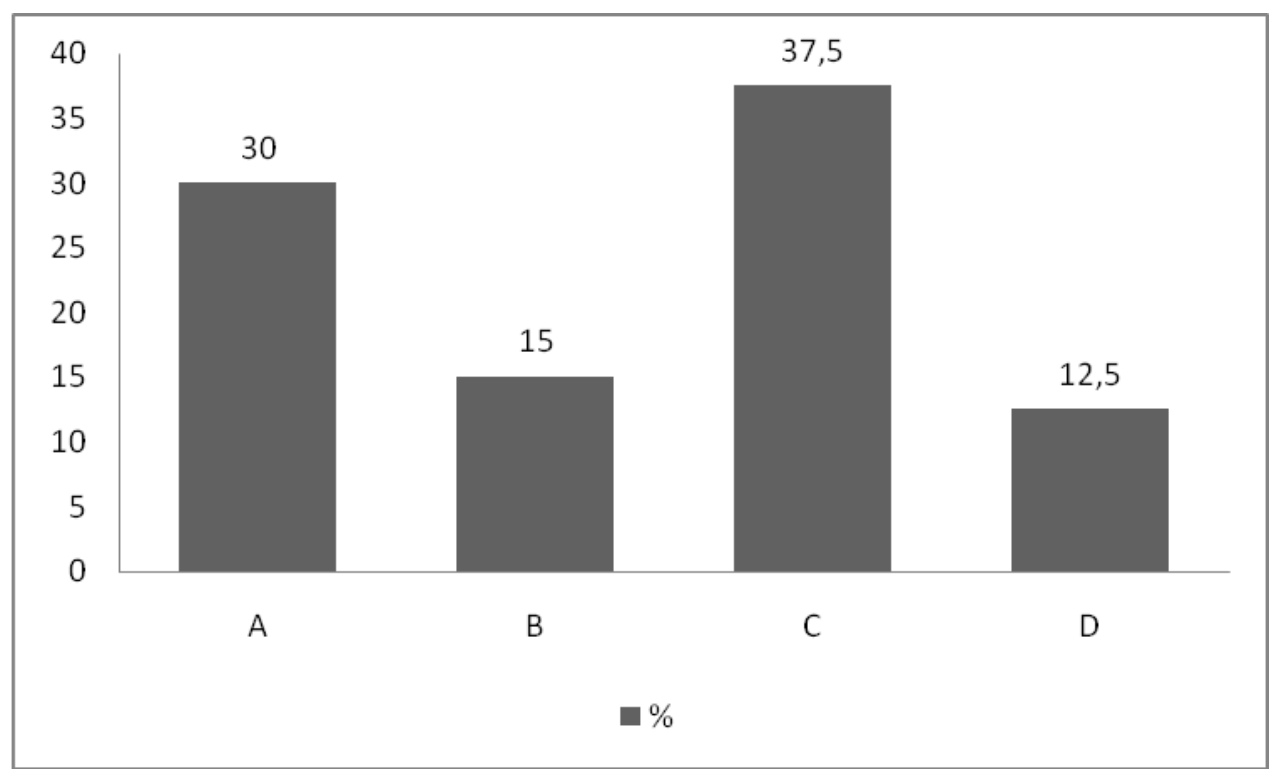


É notório o contraste relativo à realização do ato exortativo diretamente sem mostrar cortesia entre os testes chilenos $(30 \%)$ e brasileiros (2,5\%). Estas respostas respaldam alguns resultados da análise do corpus, através da qual vimos que, no contexto universitário de São Paulo, um ato exortativo, em geral, quando é realizado de forma direta também é seguido de estratégias alocêntricas como um ato de justificação ou a expressão da diminuição do custo para os ouvintes, fortalecendo a imagem de cordialidade dos falantes. À vista disso, os testes de hábitos sociais apontam a pouca frequência de atos exortativos diretos no contexto brasileiro.

Classificamos como ato direto o enunciado "João, vai rápido", porém quando analisemos os atos diretos chilenos, como "Ya, ¡basta! Nadie te está oyendo. Nos da mucha lata", veremos que podem conter singulares diferenças entre as realizações brasileiras e chilenas, apesar de que em ambos os casos temos atos exortativos impositivos.

Nesse exemplo retirado dos testes brasileiros, temos um ato exortativo, a partir do qual o falante não expressa cortesia ou consideração pela imagem do ouvinte. A forma verbal "val", nesse exemplo, está em imperativo afirmativo de segunda pessoa do singular, tu, uso que é comum na região sudeste, embora a forma de tratamento mais frequente seja "você".

Os atos diretos que encontramos nos testes chilenos apresentaram um verbo em imperativo, como "para", "sintetiza", "acuérdate", "haz" ou um marcador discursivo metadiscursivo "ya" que se localiza no início de uma intervenção para cortar o discurso do interlocutor, realizando uma operação enunciativa que mostra o controle da comunicação por parte do falante que o emprega (Andrade, 2010); as intervenções também podem conter alguns apelativos como "hue(v)ón", que chamam a atenção do interlocutor e/ou podem constituir uma chamada de cooperação e marcar, através da descortesia afirmativa falsa, aproximação social e a solidariedade.

As intervenções dos testes de Santiago também registraram atos descorteses como "Ya, jbasta! Nadie te está oyendo. Nos da mucha lata", ou seja, um ato que voluntariamente ameaça o prestígio do outro. Nesse sentido, é 
necessário relevar que quanto mais próxima é a relação entre duas pessoas, menor pode ser o grau de cortesia e, na verdade, a interpretação da descortesia dependerá, portanto, das características da situação comunicativa.

Ademais, observamos que o grau de intensidade da exortação é aumentado e intensificado nos exemplos "Mira, o lo hacís más corto o yo te corto. Vo(s) decidî" e em "Puta, jJuan! Dijimos que eran solo 5 minutos cada uno, ¿por qué te alargaste tanto? ¡Para la otra, haz caso!”, em que é possível perceber que os falantes chilenos demonstram possuir superioridade na interação.

Em 12,5\% dos testes brasileiros, registraram-se atos exortativos realizados com estratégias autocêntricas, pelos quais o falante se coloca como porta-voz do grupo e apela pela solidariedade do ouvinte, solicita também a conformidade e expressa cortesia construtiva (como em "João, ainda tem outras pessoas, se você puder resumir..."). Nos testes chilenos, em 15\% deles encontramos a mesma estratégia, embora também possam conter atos de fala diretos na mesma intervenção (como em "Juan, Juan, hey, espera um poco. Cada uno tiene cinco minutos y tú llevas siete, sin terminar todavía. Revisa tu parte, o revisémosla entre todos, para hacer una buena síntesis que quepa en cinco minutos. Si no, vamos a salir perjudicados”.)

Os testes de São Paulo e de Santiago do Chile, em maior número, apontam estratégias alocêntricas, porém com grande distância percentual, 60\% e $37,5 \%$, respectivamente.

Consideramos nesta análise, estratégias alocêntricas as que são orientadas aos interesses do interlocutor e/ou ao grupo que representa e à promoção da aloimagem, metas e desejos do outro. Portanto, a intervenção "João, o tempo já deu", que foi registrada em um dos testes, manifesta estratégias alocêntricas e evitativas num ato indireto que busca evitar a ameaça à imagem do ouvinte. O falante prefere um ato assertivo, do qual o ouvinte deverá deduzir o seu pedido ou rechaço, no lugar de enunciar um ato ilocutivo exortativo e impositivo. Certamente, no plano puramente pragmático, uma intervenção assertiva como "João, o tempo já deu” não é interpretada da mesma maneira como esta: "João, já passou o tempo, tem como dar só uma aceleradinha?", que, além do ato assertivo, contém fenômenos de atenuação, embora estejam classificadas no mesmo grupo, o grupo cujas intervenções 
apresentam estratégias de atenuação, cortesia valorizadora, pedidos de desculpas e atos indiretos.

Entre as estratégias alocêntricas e evitativas mais frequentes nestas respostas, é importante ressaltar estratégias paralinguísticas como o sorriso, o riso e o tom de brincadeira, as quais também foram observadas no corpus de São Paulo, como forma de demonstrar aceitação, amabilidade e atenuação.

Exceto a presença do riso que nos teste chilenos se revelou uma só vez, entre os testes de hábitos sociais chilenos e brasileiros encontramos recorrentes estratégias alocêntricas e evitativas e de atenuação, para mitigar a ameaça, através de táticas de: impessoalização ou plural de modéstia ("hay que ser más sintpetico" , "tenemos que avanzar", "Acho melhor a gente tentar reduzir o tempo de fala"); atos indiretos ("se acaba el tiempo", "o tempo já deu", "Você pode ser mais breve, por favor?"); vocativos valorizadores (“Juanuchoooooo", "João, querido"); pedido de desculpas ("Disculpa, Juan, pero te estás demorando mucho tiempo", "João, desculpe, mas se puder concluir sua ideia",); cortesia valorizadora (“Juan, tu parte está excelente”, “João, tá ótimo”); convenções (“por favor", "porfa"); verbos perfomativos ("Parece que", "eu acho"); e quantificadores ou diminutivos ("aceleradinha", "un poquito").

Os informantes brasileiros optam por não realizar a exortação verbalmente em $25 \%$ dos casos, e os informantes chilenos, em $12,5 \%$, e segundo o que escreveram, por motivos similares, para evitar a imposição. 


\subsection{Dados contrastivos sobre percepções dos informantes a respeito do comportamento cortês e a gestão de imagens}

Da parte I do teste de hábitos sociais que aplicamos, verificamos que, com relação ao comportamento cortês numa situação comunicativa determinada, $90 \%$ dos informantes brasileiros demonstram algum tipo de preocupação com a interação quando precisam manifestar o desacordo no contexto universitário, e dos chilenos, $82,5 \%$ responderam o mesmo.

Prevalecem justificativas que valorizam o emprego de estratégias afirmativas para proteger e fortalecer a autoimagem e a aloimagem tanto em São Paulo $(47,22 \%)$ como em Santiago do Chile $(63,63)$.

Suas justificativas indicam que os brasileiros parecem ser motivados pela valorização da imagem de cordialidade, que se identifica pela lógica relacional e a valorização da conciliação e da negociação. Mais chilenos do que brasileiros apreciam as estratégias afirmativas para proteger e fortalecer a autoimagem e a aloimagem, mas por motivos diferentes: os brasileiros que responderam ao teste indicaram alto grau de preocupação por respeitar ao ouvinte e não ofendê-lo; os chilenos, por sua vez, expressaram o mesmo além da preocupação por evitar o ataque pessoal ao ouvinte e atos descorteses, como o insulto.

Nesse sentido, para a expressão do desacordo, muitos chilenos valorizam a expressão clara de críticas ao conteúdo proposicional dos turnos dos interlocutores, desde que o interlocutor em si seja respeitado.

Em número maior, os brasileiros demonstraram preocupar-se em empregar estratégias afirmativas e valorizar o carácter relacional durante a expressão do desacordo, em prol da coletividade e humanização.

Ambos os grupos revelaram quais comportamentos são desvalorizados em suas comunidades, os quais podem favorecer mais ou menos a ocorrência de recursos de atenuação, como: ser rude, grosseiro, intolerante, autoritário, arrogante, indelicado e deselegante em São Paulo e não evitar brigas e soesussões no Chile.

Com respeito à gestão da autoimagem encontramos diferenças entre chilenos e brasileiros. Os brasileiros associaram à sua autoimagem, em maior 
grau que chilenos: ser/parecer alegre, ser/ parecer justo, ser/ parecer educado e sobressair, projetar as suas boas qualidades (aceitáveis socialmente). Já os chilenos marcaram mais estas opções do que os brasileiros: ser/ parecer inteligente, ser/parecer direto, evitar rodeios, proteger/manter a reputação e não mostrar debilidades (econômica ou intelectual).

Da parte II do teste, em que os informantes poderiam escrever o que dizem em determinadas situações, prevaleceram, em ambas comunidades de fala, a preocupação por empregar estratégias afirmativas da imagem de excelência e a proteção e o fortalecimento da auto- e da aloimagem. A maioria das intervenções escritas possui relativizadores que debilitam a força argumentativa com relação à certeza do enunciado, recursos de atenuação que previnem ou reparam, são autoprotetores e também protetores da imagem de excelência dos ouvintes.

A valorização do carácter relacional alcançou mais testes brasileiros (20\%) do que chilenos, mas ressaltamos que uma das respostas chilenas, neste caso, busca o consenso a partir da consideração da opinião do falante dentro do grupo, enquanto que os brasileiros podem abster-se ou desistir de emitir a dissenção.

O emprego de estratégias afirmativas e autocêntricas foram apontadas por $30 \%$ dos informantes chilenos e somente por $5 \%$ dos brasileiros. Através dessas táticas, o falante expressa a sua opinião, atenuando, muitas vezes, a força ilocutória do ato ou a si mesmo e, muitas vezes, observamos ameaças à face do ouvinte, sem a oferta de reparos.

No tocante à realização do ato exortativo, os testes de São Paulo e de Santiago do Chile, apontam estratégias alocêntricas, porém com grande distância percentual, $60 \%$ e $37,5 \%$, respectivamente. Além disso, 30\% dos informantes chilenos o realizariam de maneira direta sem mostrar cortesia; somente $2,5 \%$ dos brasileiros o fariam, segundo suas respostas. Assim, os testes de hábitos sociais indicam a pouca frequência de atos exortativos impositivos diretos no contexto brasileiro.

Os testes chilenos, ao contrário, contêm atos descorteses ou intensificações do ato enquanto que entre as respostas dos brasileiros estão 0 sorriso, o riso e o tom de brincadeira, como forma de demonstrar aceitação, 
amabilidade e atenuação, como estratégias alocêntricas e evitativas mais frequentes para a realização de petições.

Também há discrepância na opção de não realizar o pedido verbalmente. Os informantes brasileiros optam por não realizá-lo em $25 \%$ dos casos; e os informantes chilenos-em $12,5 \%$, segundo o que escreveram.

Para finalizar, lembramos que a utilização de técnicas escritas para a obtenção de dados permite aos investigadores ter acesso a respostas mais esteriotipadas do que aquelas que são produzidas no discurso espontâneo (Hernández-Flores, 2006). Assim, lembramos que os dados que obtivemos aqui não podem ser usados como dados empíricos de análise, mas sim como dados de apoio, para corroborá-la ou questioná-la, ajudando-nos a descrever e a identificar comportamentos (des)corteses (Hernández-Flores, 2006). 


\section{O CAPÍTULO IV \\ O CONTRASTE CROSS-CULTURAL: EXPOSIÇÃO E FUNDAMENTAÇÃO \\ DOS RESULTADOS}

Nesta etapa, no plano da pragmática contrastiva, sintetizamos as descrições e os contrastes das variações linguísticas e socioculturais entre as comunidades de fala em estudo, a partir da exposição e fundamentação dos resultados provenientes das etapas de análise que compõem a metodologia desta pesquisa. Aproximamo-nos das estratégias de cortesia encontradas nas comunidades de fala de São Paulo e Santiago do Chile bem como suas contribuições para a manutenção do equilíbrio na interação social, em encontros de estudo no âmbito acadêmico.

\section{EXPOSIÇÃO E FUNDAMENTAÇÃO DOS RESULTADOS PROVENIENTES DAS ETAPAS DE ENFOQUE INTERDISCIPLINAR, ANÁLISE DO CORPUS ORAL E APLICAÇÃO DE TESTES DE HÁBITOS SOCIAIS}

Respaldando-nos no fato de que a cortesia é um fenômeno sociocultural, tratamos de suas manifestações linguísticas a partir de um enfoque interdiciplinar, usufruindo de descrições de contextos socioculturais e conceitos teóricos de ciências que se ocupam de atividades humanas, relativas à interação social. Dessa maneira, conforme Bravo (2004a: 5), conduzimos um estudo da cortesia a partir de dois planos, o do âmbito teórico, a partir do qual procuramos estabelecer generalizações capazes de abarcar aspectos dentro da vasta diversidade do uso da linguagem; e o do âmbito das manifestações linguísticas na fala de usuários de duas línguas, o português e o espanhol, considerando particularidades de duas comunidades de fala particulares.

Alcançando as condições sociais, que proporcionam aos falantes 0 acesso e o controle de estratégias da linguagem, a partir do enfoque teórico interdisciplinar e da descrição das premissas culturais, estabelecemos 
conteúdos específicos da imagem social básica do brasileiro e do chileno, no capítulo II.

Ressaltamos que a sociedade brasileira preconiza valores como a humanização, a igualdade e a afetividade, o que favorece a procura da conciliação e da negociação. Sua identidade se caracteriza por demonstrar-se cordial e diligente quanto à valorização da coletividade, da sociabilidade e do respeito ao outro (Freyre, 1933; DaMatta, 1984, Buarque de Holanda, 1936).

$\mathrm{Na}$ cultura chilena, o conceito de ordem é um dos articuladores do consenso social; e valores como o respeito ao próximo, a sua reputação e à posição social consistem convenções socioculturais subjacentes à interação. $A$ prevenção de conflitos, o cuidado da relação interpessoal e a manutenção da ordem são, portanto, premissas para a manutenção da harmonia social chilena (Stuven, 1997; Scheele, 2010, Puga, 2013a).

Notoriamente, de modo nenhum queremos dizer que os traços das premissas e valores culturais que acabamos de resumir aqui se traduzem na forma como os indivíduos procedem ou devam atuar em suas sociedades. No caso do brasileiro, por exemplo, não afirmamos que é essencialmente cordial, respeitoso ou simpático, absolutamente. Tampouco julgamos que o chileno, em especial, acata continuamente as ordens e aceita as conformações hierárquicas. Efetivamente, oferecemos uma descrição de valores socioculturais que proporcionam informação sobre as imagens sociais que têm a necessidade de serem projetadas num contexto específico, na gestão da autoimagem, porque, do contrário, para o indivíduo poderia haver ameaça de exclusão ou rechaço social. Em outras palavras, os valores sociais que descrevemos se relacionam mais com a necessidade do "parecer ser" do que com o "ser".

No contexto brasileiro, com foco na gestão da autoimagem, identificamos, de maneira generalizada, a necessidade de o indivíduo exteriorizar e projetar: a imagem de cordialidade (mostrar-se amigável e evidenciar respeito ao interlocutor, valorizando a coletividade e a conciliação), formulada nesta pesquisa; a imagem de cooperação (Fant e Granato, 2002) (projetar-se como disposto a cooperar com os demais ou renunciar a interferir) e a imagem de semelhança (Fant e Granato, 2002) (projetar certo grau de semelhança com os outros membros da interação). 
Para as interações chilenas, discernimos a imagem de ordem (projetar uma valorização da ordem e respeito à mesma e à hierarquia), apresentada nesta pesquisa, e a imagem de hierarquia (Fant e Granato, 2002) (mostrar que Ihe corresponde certa posição hierárquica).

A identificação dos conteúdos da imagem social do brasileiro e do chileno nos permitiu, na fase de análise do corpus, no capítulo III, explicar e descrever realizações linguísticas e táticas pragmáticas dentro da própria interação social segundo a adequação dos modos de comportamento verbal às convenções sociais (Bravo, 2004a).

Selecionamos atos assertivos e diretivos, fundamentando-nos em Haverkate (2004), e descrevemos e contrastamos estratégias de cortesia envolvidas na construção da imagem dos participantes da interação brasileira e chilena.

No tocante ao ato assertivo, constatamos a implicação do fenômeno linguístico de autorrepetição na expressão do grau de capacidade intelectual e o reforço da imagem de hierarquia e de excelência, no corpus de São Paulo e de Santiago do Chile.

A autorrepetição, tanto no Chile, como no Brasil, ocorre com frequência no discurso do falante que detém a voz instrutiva. Usualmente, esse fenômeno opera no processo formulativo, como estratégia pragmática para produzir uma linguagem mais eficiente ou precisar ideias.

A análise do corpus, corroborada pela análise dos testes de hábitos sociais, revelaram, portanto, que a imagem de excelência também compõe a imagem básica dos informantes brasileiros e chilenos nos encontros de estudo, que sentem a necessidade de projetar as suas boas qualidades ou de confirmarIhe ao ouvinte a percepção de suas "boas qualidades", seu saber e conhecimento no contexto acadêmico.

Nesse sentido, encontramos no corpus mecanismos de intensificação vinculados à força argumentativa e que fazem parte das estratégias que os falantes, brasileiros e chilenos, utilizam para reforçar o conteúdo locutório e ilocutório de seus atos de fala. Tais mecanismos são viabilizados pela valorização da imagem de excelência e hierarquia.

No entanto, no corpus brasileiro, sinalizamos em maior grau do que no chileno a presença de marcadores discursivos de controle de contato, 
movimentos de justificação e estratégias alocêntricas e evitativas de cortesia construtiva que buscam, ao mesmo tempo, salvaguardar e promover a auto- e a aloimagem.

Quanto aos fenômenos de atenuação, apareceram em maior número nas intervenções brasileiras, para expressar cortesia nesta valorização das imagens públicas, edificando o consenso através de posturas afiliativas.

Os mecanismos de atenuação encontrados no corpus de São Paulo, na maior parte das vezes, indicam hesitação ou distanciamento da asserção e podem sugerir a abertura e o intercâmbio de ideias e opiniões, valorizando a imagem de cooperação, semelhança, possibilitando também a negociação, com base em que mostrar-se pouco impositivo é um valor social nessa comunidade de fala. No corpus chileno, a atenuação participou com mais frequência na atividade do falante se constituindo uma estratégia para prevenir possíveis danos à própria imagem segundo a possível avaliação dos interlocutores, o que é um mecanismo autocêntrico.

No tocante ao fenômeno linguístico da heterorrepetição, entre os informantes brasileiros, frequentemente transmite cortesia, pode promover 0 contato social e reforçar imagens, sinalizando a atividade da imagem autocêntrica e alocêntrica de cooperação, podendo ocorrer na expressão do acordo, reforçando ademais a imagem de hierarquia e excelência do outro.

No Chile, a heterorrepetição, no geral, participa de atividades afirmativas e autocêntricas, para manifestar o desacordo ou participar da co-construção do discurso com seu interlocutor, a fim de projetar o seu conhecimento. De qualquer maneira, esse fenômeno linguístico no Chile também pode transmitir cortesia de maneira similar ao que identificamos no Brasil.

$\mathrm{Na}$ análise do ato de exortativo, com foco na petição, notamos singulares diferenças na sua realização no Brasil e no Chile. Embora o ato possa ocorrer de maneira direta, sem manifestar cortesia, tanto no corpus brasileiro quanto no chileno, em português com frequência o ato não cortês é seguido de ato de justificação ou da expressão da diminuição do custo para os ouvintes, com base na escala de custo-benefício (Leech, 1983). No corpus chileno, quando um interactante sente a necessidade de projetar uma valorização da ordem e respeito à mesma, mostra o controle da comunicação mediante uma petição que frequentemente não apresenta recursos de atenuação. 
Ao promover e elaborar a descrição de um corpus específico nos perguntamos qual é a sua utilidade e contribuição científica. Indagamo-nos também se as experiências de um corpus podem ultrapassar os seus próprios limites (Charaudeau, 2012). Se analisarmos um corpus a partir da perspectiva funcionalista da pragmática, a partir dos pressupostos dos imaginários sociais dos usuários de uma língua e de seu contexto social e cultural, podemos contemplar as condições socioculturais que permitem que um indivíduo administre os recursos linguísticos da cortesia o que nos permite estabelecer generalizações.

Nesse sentido, na terceira fase de nossa metodologia, como é sabido, descrevemos os resultados dos testes de hábitos sociais aplicados a informantes universitários de São Paulo e de Santiago do Chile. Esses testes, questionários escritos, constituem um material de apoio para extrair informações dos pressupostos dos falantes sobre as estratégias sociais válidas em suas comunidades de fala e sobre como thes parece (in)adequado atuar numa determinada situação comunicativa.

Podemos aproximarmos de generalizações sobre as estratégias que ocorrem nos modos de formulação em determinados atos de fala e situações comunicativas com base na comparação dos resultados obtidos nas duas etapas anteriores, o enfoque interdisciplinar e a análise do corpus e, assim, encontrar elementos comuns e regularidades.

No que se refere ao ato assertivo e à expressão do desacordo, a análise das respostas dos testes de hábitos sociais, aplicados a 40 estudantes universitários brasileiros e 40 universitários chilenos, evidenciaram que $47 \%$ dos informantes brasileiros se preocupam em empregar estratégias afirmativas das imagens de cordialidade, semelhança, cooperação e excelência e promover a autoimagem e a aloimagem. Dos chilenos, $63,63 \%$ procuram utilizar estratégias afirmativas da imagem de excelência e, como os brasileiros, proteger e fortalecer a autoimagem e a aloimagem.

Assim, alguns informantes chilenos valorizam a expressão clara de críticas ao conteúdo proposicional dos turnos dos interlocutores, desde que o interlocutor em si seja respeitado. Os brasileiros, por sua vez, justificaram-se valorizando uma maneira de atuar conciliadora.Dessa forma, na universidade, os estudantes brasileiros tendem a fortalecer a imagem do ouvinte e suas 
intervenções, lembrando que ao fazê-lo, protegem suas próprias imagens, a fim de que sejam socialmente aceitos.

De qualquer forma, tanto a maioria dos chilenos quanto a maior parte dos brasileiros demonstraram utilizar estratégias afirmativas para proteger e fortalecer a auto- e a aloimagem, porém os brasileiros parecem ser motivados pelo caráter relacional de seu contexto social e os direitos e necessidades do ouvinte, o que promove a sua autoimagem. Os chilenos, por sua vez, expressaram em maior grau a valorização de estratégias evitativas, para evitar o ataque pessoal ao ouvinte e atos descorteses, como o insulto.

Numa questão de múltipla escolha, com trinta e duas opções, no que é concernente à projeção da autoimagem no contexto acadêmico, informantes das duas comunidades de fala indicaram bastante similaridades, e todos marcaram com prevalência as características mais valorizadas em seus contextos: ser/parecer amigável, simpático, um bom ouvinte e argumentar. Com relação aos contrastes, isto é, traços mais escolhidos por um grupo do que por outro, observamos que os brasileiros consideram mais: ser/parecer alegre, justo, educado, inteligente, sobressair, projetar as suas boas qualidades, enquanto que mais chilenos demonstraram valorizar: ser/parecer direto, evitar rodeios, mostrar interesse pelo outro, proteger/manter a reputação e não mostrar debilidades (econômica ou intelectual).

Os resultados da análise do corpus puderam refletir as escolhas dos informantes, na medida em que algumas opções escolhidas pelos chilenos favorecem em maior grau a ameaça à face do ouvinte, como "ser/ parecer direto", enquanto que os brasileiros revelaram a manifestação de mais estratégias afiliativas, muitas vezes com o objetivo de projetar as suas boas qualidades.

Uma parte dos testes de hábitos sociais propôs aos informantes escreverem em discurso direto o que dizem em situações específicas e, apesar de que suas respostas proporcionaram dados muito relevantes, a produção escrita não permite que tenhamos acesso à espontaneidade da produção oral em um contexto natural, assim, a complexidade do processo formulativo não pode ser contemplada. 
Neste passo, os informantes tinham que se imaginar em uma situação comunicativa em que poderia ocorrer o ato de correção dos interlocutores, colegas universitários em um grupo de estudos.

Em ambas as comunidades de fala, de forma bastante similar, a maioria das intervenções estão atenuadas com elementos relativizadores que debilitam a força argumentativa com relação à certeza do enunciado, que podem prevenir ou reparar a imagem de excelência do falante e dos ouvintes. Isto pode reiterar que os contextos sociais de cada grupo favorecem a utilização de recursos de atenuação, apesar de que não suceda pelas mesmas razões.

$O$ contexto de uso da linguagem desses falantes mais uma vez estabeleceu contraste quanto ao emprego de estratégias afirmativas e autocêntricas: ocorreram em $5 \%$ dos testes paulistanos e em 30\% dos chilenos. Referimo-nos a intervenções que, embora possam conter elementos atenuadores da opinião ("No estoy de acuerdo, yo creo que es", "Pessoal, eu acho que a resposta é $x$, pois"), podem em seguida também ameaçar a face do ouvinte, sem a oferta de reparos ("vocês deixaram passar alguma coisa", “¿cómo va a ser $x$ ? "). A prevalência deste tipo de estratégias no contexto chileno corrobora os conteúdos de imagem básica que formulamos e que também encontrou correspondências no corpus oral.

Outra questão do teste de hábitos sociais possibilitou a produção de um ato exortativo, no contexto do encontro acadêmico para a preparação de um seminário, em cujo ensaio um dos colegas se excedia com relação ao seu tempo pré-determimado de apresentação.

Os testes de São Paulo e de Santiago do Chile, em maior número, apontam estratégias alocêntricas para a realização do ato exortativo, porém com grande distância percentual, 60\% e 37,5\%, respectivamente. Essas estratégias podem propiciar a presença de mecanismos de atenuação que reforçam os laços de amabilidade, protegem as faces do falante e ouvintes e valorizam as relações igualitárias.

Em ambas as comunidades de fala, encontramos recorrentes formas de atenuação, como: impessoalização ou plural de modéstia, atos indiretos, vocativos valorizadores, pedido de desculpas, cortesia valorizadora, pedidos convencionalizados; verbos perfomativos e quantificadores ou diminutivos. Nesse âmbito, estratégias paralinguísticas como o sorriso, o riso e o tom de 
brincadeira, que já tinham sido encontradas no corpus de São Paulo, também estiveram presentes em maior número, nos testes brasileiros, como forma de amenizar a imposição.

$\mathrm{Na}$ análise das respostas desta questão, salientou-se o contraste relativo à realização do ato de petição direto, que não mostra cortesia, entre os testes chilenos $(30 \%)$ e brasileiros $(2,5 \%)$, o que pode ser justificar-se através das condições socioculturais se levarmos em conta que na cultura chilena o conceito de ordem e hierarquia são articuladores do consenso social bem como 0 respeito ao próximo, de modo que o indivíduo que não manifesta esses conteúdos de imagem pode sofrer ameaças à sua imagem. Algumas intervenções dos testes de Santiago do Chile também registraram atos descorteses como "Ya, ibasta! Nadie te está oyendo. Nos da mucha lata", apesar de que a interpretação da descortesia dependerá das características da situação comunicativa. Além disso, na presença de atos intensificados como "Mira, o lo hacís más corto o yo te corto. Vo(s) decidi" é possível perceber que os falantes chilenos demonstram possuir superioridade na interação. 


\section{CONCLUSÕES}

Podemos, nesta seção, tratar da validade científica dos aspectos metodológicos que apresentamos e aplicamos nesta tese, considerando os objetivos mencionados na introdução. Resumimos também os resultados desta investigação, cuja fundamentação, de maneira integradora, apresentamos no capítulo IV.

Nesta pesquisa, centramo-nos em descrever e contrastar estratégias pragmáticas com foco nas de cortesia em português e espanhol - em comunidades de fala de São Paulo e Santiago do Chile -, aproximando-nos da forma como esses recursos contribuem para a manutenção do equilíbrio na interação social, em encontros de estudo no âmbito acadêmico.

Apresentamos, ademais, aspectos da idiossincrasia de ambas as comunidades de fala, suas atitudes, pressupostos, premissas e valores culturais; como também identificamos crenças linguísticas quanto às funções da cortesia no âmbito acadêmico e na dinâmica das relações sociais. Com relação à gestão das imagens, identificamos e contrastamos recursos e necessidades, em determinados atos de fala, partindo do contexto específico de encontros de estudo. Enfim, contemplamos e contrastamos variações linguísticas e socioculturais entre as comunidades de fala em análise.

Com fundamentação em Bravo (2010), elaboramos aspectos práticos para uma pesquisa na área da Pragmática contrastiva, com quatro etapas metodológicas:

1) $O$ enfoque interdisciplinar, mediante fontes científicas que evidenciam o estudo de atitudes e comportamentos humanos na área da Pragmática, Sociologia, Antropologia, História, Psicologia, etc., visa a aproximar o analista das condições sociais que permitem que os falantes tenham acesso e controlem os recursos da linguagem, a fim de criar ferramentas de análise (como os componentes da imagem básica), buscar conhecimentos e construir hipóteses que contribuem para o reconhecimento das (in)adequações linguísticas e evaluações do que pode ser (des)cortês. 
2) $\mathrm{Na}$ análise do corpus examina-se um corpus com ponto de partida nos conhecimentos socioculturais delineados na etapa anterior. Selecionam-se atos de fala específicos, segundo os interesses do estudo, e são analisadas as suas consequências imediatas, estendendo-se ao contexto de enunciação.

3) A aplicação de testes de hábitos sociais (Hernández Flores (2002), Contreras (2004) e Bernal (2007)), nesta etapa são formulados e aplicados questionários cujas respostas podem apoiar as interpretações obtidas da análise do corpus, a partir da comparação dos resultados obtidos nas etapas anteriores. A partir desta ferramenta também é possível precisar e corroborar as características da imagem social e dos valores culturais subjacentes ao comportamento (des)cortês e evitar que o analista induza da primeira fase da pesquisa suposições que poderiam encontrar eco in situ, em um corpus específico e reduzido, o que o seria possível levá-lo a construir generalizações ilusoriamente empíricas.

4) O contraste cross-cultural constitui a etapa de exposição e fundamentação dos resultados, contemplando as variações linguísticas e socioculturais entre as comunidades de fala em estudo.

Valorizamos o contexto sociocultural como uma ferramenta metodológica, a partir de fontes escritas, estudos interdisciplinares do comportamento humano. Uma vez que assentimos que a imagem social é delimitada socioculturalmente, buscamos demonstrar que traços do contexto sociocultural são profícuos para clarificar os rudimentos da gestão de imagens interrelacional, em uma determinada comunidade de fala. Embora nosso interesse central não seja 0 elemento extralinguístico, reconhecemos que este produz fatores determinantes do comportamento comunicativo.

Reiteramos que o uso de elementos do contexto sociocultural como ferramenta de análise não permite a construção de categorias estáticas, ao contrário, possibilita a elaboração de ferramentas adaptáveis, para abordar a complexidade e a diversidade de situações comunicativas dentro de uma comunidade fala em estudos contrastivos.

Nesse sentido, no contexto acadêmico brasileiro, com foco na gestão da autoimagem, identificamos, de maneira generalizada, a necessidade de 0 
indivíduo exteriorizar e projetar: a imagem de cordialidade (mostrar-se amigável e evidenciar respeito ao interlocutor, valorizando a coletividade e a conciliação), formulada nesta pesquisa; a imagem de cooperação (Fant e Granato, 2002) (projetar-se como disposto a cooperar com os demais ou renunciar a interferir) e a imagem de semelhança (Fant e Granato, 2002) (projetar certo grau de semelhança com os outros membros da interação).

No contexto chileno, discernimos a imagem de ordem (projetar uma valorização da ordem e respeito à mesma e à hierarquia), estabelecida nesta pesquisa, e a imagem de hierarquia (Fant e Granato, 2002) (mostrar que lhe corresponde certa posição hierárquica).

Identificamos, pois, conteúdos de imagem que, embora não sejam estáticos, fazem parte das premissas culturais e, portanto, são aplicáveis a variadas situações comunicativas e trabalham em conjunto com outros conteúdos de imagem que a situação comunicativa levante.

No nível do discurso oral presente em grupos de estudos universitários, constatamos que o fenômeno linguístico da autorrepetição, tanto no Chile como no Brasil, pode ser um recurso do falante que detém a voz instrutiva. Esse fenômeno ocorre no processo formulativo, como estratégia pragmática para produzir uma linguagem mais eficiente ou precisar ideias.

Entretanto, de um modo geral, quanto aos fenômenos de atenuação, evidenciamos que apareceram em maior número nas intervenções brasileiras, para expressar cortesia para a valorização das imagens sociais, edificando o consenso através de posturas afiliativas. Assim, em grande parte das vezes, indicam hesitação ou distanciamento da asserção e/ou sugerem a abertura e o intercâmbio de ideias e opiniões, valorizando a imagem de cooperação e semelhança.

No corpus chileno, a atenuação assertiva participou com mais frequência na atividade do falante, constituindo-se uma estratégia para prevenir possíveis danos à própria imagem com base na avaliação dos interlocutores, o que é um mecanismo autocêntrico, ou seja, não expressa cortesia.

De igual modo, encontramos mecanismos de intensificação vinculados à força argumentativa e que fazem parte das estratégias que os falantes, brasileiros e chilenos, utilizam para reforçar o conteúdo locutório e ilocutório de seus atos de fala. 
Concluímos, portanto, na enunciação assertiva, que as estratégias mais frequentes na comunidade de fala brasileira analisada são as afirmativas das imagens de cordialidade, semelhança, cooperação e excelência. E no contexto chileno analisado, tendem a ocorrer estratégias afirmativas da imagem de ordem e excelência.

A respeito do fenômeno linguístico da heterorrepetição, entre os informantes brasileiros, frequentemente transmite cortesia, promove o contato social e reforça imagens, sinalizando a atividade da imagem autocêntrica e alocêntrica de cooperação, podendo ocorrer na expressão do acordo, reforçando inclusive a imagem de hierarquia e excelência do outro. Em interações chilenas, a heterorrepetição, no geral, participa de atividades afirmativas e autocêntricas, para manifestar o desacordo ou participar da co-construção do discurso com seu interlocutor, a fim de o falante projetar o seu conhecimento. Apesar disso, esse fenômeno linguístico no Chile também pode transmitir cortesia de maneira similar ao que identificamos no Brasil.

Grande parte de informantes chilenos valorizam a expressão clara de críticas ao conteúdo proposicional dos turnos dos interlocutores, desde que o interlocutor em si seja respeitado. Os brasileiros, por sua vez, valorizam uma maneira de atuar conciliadora. Assim, na universidade, os informantes brasileiros tendem a fortalecer a imagem do ouvinte e suas intervenções, lembrando que ao fazê-lo, protegem suas próprias imagens, a fim de que sejam socialmente aceitos.

Os brasileiros parecem ser motivados pelo caráter relacional de seu contexto social e os direitos e necessidades do ouvinte, o que promove a sua autoimagem. Os chilenos, por sua vez, expressaram em maior grau a valorização de estratégias evitativas, para atenuar ou não realizar o ataque pessoal ao ouvinte.

$\mathrm{Na}$ incidência do ato de exortativo, com foco na petição, demonstramos que nas interações chilenas e brasileiras 0 ato pode ocorrer de maneira direta, sem manifestar cortesia, contudo em português, com frequência, esse ato não cortês é seguido de justificação ou da expressão da diminuição do custo para os ouvintes, com base na escala de custo-benefício (Leech, 1983). Em encontros comunicativos chilenos, quando um interactante sente a necessidade de projetar uma valorização da ordem e respeito à mesma, mostra o controle da 
comunicação mediante uma petição que frequentemente não apresenta recursos de atenuação.

Tanto em situações comunicativas no Chile ou no Brasil, discernimos estratégias alocêntricas semelhantes para a realização do ato exortativo, porém com grande distância percentual, em maior número em nosso país. Essas estratégias podem propiciar a presença de mecanismos de atenuação que reforçam os laços de amabilidade, protegem as faces do falante e ouvintes e valorizam as relações igualitárias.

Todavia, as interações chilenas revelaram um maior número do que no Brasil de atos de petição diretos, sem mostrar cortesia. Na análise desse ato de fala, algumas intervenções dos testes de Santiago do Chile também registraram atos descorteses, que estiveram ausentes no contexto brasileiro analisado.

Pudemos reconhecer, nesta pesquisa, que, além da preocupação de preservar sua liberdade de ação, de obter a aprovação dos demais e de que sejam compartilhadas as mesmas opiniões e desejos pessoais, em situações de negociação existem necessidades mais complexas, relativas à gestão das imagens sociais. Assim, também pudemos ressaltar que as atividades de imagem não trabalham todas para o fomento da cortesia linguística, mas muitas vezes para a própria imagem (Bravo, 2002b).

Respondemos portanto nossas perguntas de pesquisa iniciais:

a) quais aspectos das premissas culturais, nos contextos socioculturais que compartilham os falantes, permitem-lhes que uma interpretação de expressões de cortesia seja (in)adequada à situação? b) qual a interrelação entre as imagens que concebem os estudantes brasileiros e chilenos e as estratégias de cortesia adotadas pelos informantes do corpus? c) quais são as principais diferenças observadas na busca do equilíbrio social entre os estudantes chilenos e brasileiros em encontros de estudo?

Pudemos, em vista disso, aproximarmos de generalizações, estratégias advindas da gestão interrelacional que se da com base nos conteúdos de imagem que formulamos para a comunidade de fala brasileira e chilena. Esses resultados obtidos a partir das coincidências entre as etapas da metodologia nos permitiu encontrar, assim, elementos comuns e regularidades que não são tão somente observáveis em um corpus específico, mas podem ser reconhecidas em outras situações comunicativas, uma vez que se fundamentam nas 
premissas culturais, sem perder de vista, contudo, a diversidade das interações verbais.

Finalmente, no âmbito de ensino de espanhol como língua estrangeira (ELE) ou português para falantes de outras línguas (PFOL), apresentamos aqui alguns aspectos linguísticos com forte relação social, que poderão ser usados posteriormente com objetivos didáticos, sempre que sejam enfocadas as variações dos contextos comunicativos. Esses resultados proporcionam recursos para que um aprendiz de ELE ou PFOL possa compreender melhor os comportamentos do outro, prescindindo da avaliação baseada em sua própria cultura. Questões de cortesia e aspectos pragmáticos são essenciais para poder relacionar-se e integrar-se na sociedade, de modo que seu conhecimento pode oferecer a qualquer falante consequências singulares. 


\section{BIBLIOGRAFIA}

ALVAREZ MURO, A. (2005) Cortesía y descortesía: Teoría y praxis de un sistema de significación. Mérida, VE: Universidad de los Andes.

AUSTIN, J. L. (1970) Ensayos filosóficos. Madri: Revista de Occidente.

. (1962). How to do things with words. Oxford: University Press.

ALBELDA MARCO, M. (2004). Cortesía en diferentes situaciones comunicativas. La conversación coloquial y la entrevista sociológica semiformal. In: BRAVO, D.; BRIZ, A. Pragmática sociocultural: estudios sobre el discurso de cortesía en español. Barcelona: Ariel, pp.109-134.

(2005). La intensificación en el español coloquial. Universidad de Valencia: Servei y Publicaciones.

. (2008) Atenuantes en Chile y en España: distancia o acercamiento. In: BRIZ, A.; HIDALGO, A. (Eds.).Cortesía y conversación: de lo escrito a lo oral. Coloquio Internacional EDICE, 3. Valência: Departamento de Filología Española de la Facultat de Filologia, Traducció i Comunicació de la Universitat de València / Programa EDICE.

.; CONTRERAS, J. (2009). Imagen de afiliación y atenuantes en un análisis contrastivo alemán/español. In: Acta Universitatis Stockolmiensis. Estocolmo: Departamento de Español, Portugués y Estudios Latinoamericanos Universidad de Estocolmo, pp. 7-30

ANDRADE, A. M. de; SILVA, C. (2008). Cortesía y relevancia en el portugués de Brasil y español de Chile. In: Congreso Internacional de ALFAL, 15., 18-21 ag. 2008, Montevideo, UY. Actas. Montevideo, UY.Disponível em: $<$ http://alfal.easyplanners.info/programa/buscar.php?id_tl=983>.

, (2010). Cortesia e marcadores discursivos: contrastes entre discursos orais chilenos e espanhóis e as percepções de brasileiros. Dissertação (Mestrado em Letras - Língua Espanhola e Literaturas Espanhola e Hispano-Americana), Faculdade de Filosofia, Letras e Ciências Humanas, Universidade de São Paulo, São Paulo.

.; Lopes, E. C. M. R. (2012). La cortesía verbal en los encuentros orales con fines de estudio: las estrategias linguístico-discursivas de atenuación en portugués y español. In: Escamilla Morales, J.; Henry Vega, G. (Eds.). Miradas multidisciplinares a los fenómenos de cortesía y descortesía en el mundo hispánico. Barranquilla: Universidad del Atlántico/Programa EDICE, pp. 369-391. Disponível em <http://edice.org/>. 
APPA, R. C. (2005). Polidez Linguística nas Conversações de Telemarketing. Tese apresentada ao Programa de Pós-graduação em Filologia e Língua Portuguesa,Departamento de Letras Clássicas e Vernáculas, Faculdade de Filosofia, Letras e Ciências Sociais, Universidade de São Paulo, São Paulo.

BACH, K; HARNISH, R. (1979). Linguistic Communication and Speech Acts. Cambridge: The Mit Press.

BALLESTEROS MARTÍN, F. J. (2002).Mecanismos de atenuación en español e inglés: implicaciones prgamáticas en la cortesia. Clac. Universidad Complutense de Madrid. Disponível em: <http://www.ucm.es/info/circulo/no11/ballesteros.htm>.

BARBOSA, L. (1992). O Jeitinho Brasileiro. Rio de Janeiro:Campus.

BEINHAUER, W. (1968). El español coloquial. 2. ed.Versão espanhola: Fernando Huarte Morton.Madri: Gredos.

BERNAL, M. (2007).Categorización sociopragmática de la cortesía y de descortesía. Un estudio de la conversación coloquial española. Tese de doutorado, Universidad de Estocolmo, Estocolmo.

BLAS ARROYO, J. L. (1998). Un caso de variación pragmática: sobre la ampliación significativa de un marcador discursivo en el español actual. Aspectos estructurales y sociolingüísticos.Revista de Filología de la Facultad de Filosofía y Letras,AnMal electrónica, v. 21, 543-571, Disponível em:

$<\mathrm{http}: / /$ dialnet.unirioja.es/servlet/articulo?codigo=85112\&orden=26066\&info $=$ link $>$.Acesso em: 14 jul. 2009.

BLUM-KULKA, S.; et. al. (1989) Cross-Cultural pragmatics: requestes and apologies. Nova Jersey: Ablex Publishing Corporaton.

BRAVO, D. (1996). La risa en el regateo: Estudios sobre el estilo comunicativo de negociadores españoles y suecos. Estocolmo: Stockholms Universitet, Edsbruk Akademi-Tryck AB.

(2001). Sobre la cortesía lingüística, estratégica y conversacional en español.Oralia,v.4, pp. 299-314.

(2002a). "Actos asertivos y cortesía. Imagen de rol en el discurso de académicos argentinos". In: M. E. Placencia; D. Bravo (eds.). Actos de habla y cortesía en español. Londres: Lincom, Studies in Pragmatics 5, pp. 141-174.

. (2002b). ¿Imagen "positiva" vs. Imagen "negativa"? Pragmática sociocultural y componentes de face. Oralia, v.2, pp. 155-184. 
(2004a). Panorámica breve acerca del marco teórico y metodológico. In: BRAVO, D; BRIZ, A. (2004). Pragmática sociocultural: estudios sobre el discurso de cortesía en español. Barcelona: Ariel, pp. 5-11.

(2004b). Tensión entre universalidad y relatividad en las teorías de la cortesía. In: BRAVO, D; BRIZ, A. (2004).Pragmática sociocultural: estudios sobre el discurso de cortesía en español. Barcelona: Ariel, pp. 15-38.

(2005) Categorías, tipologías y aplicaciones: Hacia una redefinición de la "cortesía comunicativa". In: BRAVO, D. (ed.) Estudios de la (des)cortesía en español: categorías conceptuales y aplicaciones a corpora orales y escritos, pp. 21-52. Buenos Aires: Dunken / Estocolmo: Programa EDICE.

. (2009). Pragmática, sociopragmática y pragmática sociocultural del discurso de la cortesía. Una introducción.In:BRAVO, D; HERNÄNDEZ FLORES, N. CORDISCO, A.Aportes pragmáticos, sociopragmáticos y socioculturales a los estudios de la cortesía en español. Estocolmo Buenos Aires: Dunken.

(2010). Pragmática sociocultural. La configuración de la imagen social como premisa socio-cultural para la interpretación de actividades verbales y no verbales de imagen. In: F. Orletti y L. Mariottini (Eds.).(Des)cortesía en español. Espacios teóricos y metodológicos para su estudio, pp. 19-45. Estocolmo:Programa EDICE/ Roma: Università degli Studi Roma Tre

BRIZ, A. (1997). Los intensificadores en la conversación coloquial. In: A. Briz, J.R. Gómez Molina, M.J. Martínez Alcalde; Grupo VAL.ES.CO (Eds.). Pragmática y gramática del español hablado. Zaragoza: Pórtico, pp. 13-36.

.(1998). El español coloquial: situación y uso. Madri: Arco/Libros.

. (2001). El español coloquial en la conversación. Esbozo de pragmática. Barcelona: Ariel.

(2002a). La atenuación en una conversación polémica. In: J.L. Blas Arroyo, M. Casanova Ávalos, M. Velando Casanova (Eds.): Discurso y Sociedad: Contribuciones al estudio de la lengua en contexto social. Castellón: Universitat Jaume I.

.;GRUPO VAL.ES.CO.(2002b). Corpus de Conversaciones Orales. Oralia; Anejos; Madri: Arco Libros.

(2003). La estrategia atenuadora en la conversación cotidiana española. In: D. Bravo (Ed.).Actas del Primer Coloquio Edice. La perspectiva etnocentrista de la cortesía: identidad sociocultural de las comunidades hispanohablantes. Estocolmo: Universidad de Estocolmo, pp.17-43.

(2004), Cortesía verbal codificada y cortesía verbal interpretada en la conversación. In: BRAVO, D.; BRIZ, A (Eds.).Pragmática sociocultural: 
estudios sobre el discurso de cortesía en español. Barcelona: Ariel, pp.6794.

(2007) El Diccionario de Partículas Discursivas del Español (DPDE). Disponível em: <http://www.textodigital.com/P/DDPD/>.

.; SILVA, L. A. da, ANDRADE, A. M. de; CAGGIANO BLANCO, R. C. H. (2013). A atenuação e os atenuadores: estratégias e táticas. Linha D'Água [Online], v. 26, no. 2, pp. 281-314, 2013. Disponível em: <http://www.revistas.usp.br/linhadagua/article/view/64415>.

BROWN, P., LEVISON, S. [(1976) (1987)]. Politeness. Some Universals in language use. Cambridge: Cambridge University Press.

CAISAMIGLIA, H.;Tusón, A. (1999). Las cosas del decir.Barcelona: Ariel.

CARRICABURRO, N (1997). Las fórmulas de tratamiento en el español actual. Madrid: Arco Libros.

CASTILHO, A. T. de \& PRETI, D. (1986). A Linguagem Falada Culta na Cidade de São Paulo: materiais para seu estudo. São Paulo: T.A.Queirós/ Fapesp, v.1, Elocuções Formais.

CATALÁN, D. (1989). Génesis del español atlântico, El español. Orígenes de su diversidad. Madri: Paraninfo, pp. 119-126.

CEPEDA, G.; POBLETE, M. T. (2006).Cortesía verbal y modalidad: Los marcadores discursivos. Revista Signos, v.39, n.62, p.357-377.

CHARAUDEAU, P. (2003). El discurso de la información. La construcción del espejo social. Madrid: España.

(2012). Problemas teóricos y metodológicos en los estudios de la oralidad la cortesía: aspectos linguísticos, pragmáticos y discursivos. In: Escamilla Morales, J., y Henry Vega, G. (Eds.). Miradas multidisciplinares a los fenómenos de cortesía y descortesía en el mundo hispánico. Barranquilla: Universidad del Atlántico /Programa EDICE, pp. 13-32. Disponível em:<http://edice.org/>.

CONTRERAS FERNÁNDEZ, J. (2004). El uso de la cortesía y las sobreposiciones en las conversaciones. Un análisis contrastivo alemánespañol. Tese de doutorado. Valencia: Servei de publicacions, Universitat de València.

CORDISCO, A. (2002). Afiliación y desafiliación: contexto cultural en el análisis de la interrupción y de sus consecuencias sociales en la interacción. In:Actas del primer Coloquio del programa EDICE. La perspectiva no etnocentrista de la cortesía: identidad sociocultural de las comunidades hispanohablantes.Estocolmo: Universidad de Estocolmo. Disponível em: $<$ www.edice.org $>$. 
COUTINHO, O. R. (2005). Gillberto Freyre ou o Ideário Brasileiro. Rio de Janeiro: Topbooks.

CRYSTAL, D. (1985) Dicionário de Linguística e fonética. Rio de Janeiro: Jorge Zahar.

DAMATTA, R. (1984). O que faz o Brasil, Brasil?. 12. ed. São Paulo: Rocco.

DIK, S. (1989). The Theory of Functional Gramma:The Structure of the Clause.Dordrecht: Foris Publications.

DIJK, T. A. van. (2012). Discurso e contexto: uma abordagem sociocognitiva.Tradutor: Rodolfo llari. São Paulo: Contexto.

ESCANDELL-VIDAL, M. V. (1995). Cortesía, fórmulas convencionales y estrategias indirectas. Revista española de lingüística, ISSN 0210-1874, Año № 25, Fasc. 1, 1995, pp. 31-66.

. (1996). Introducción a la pragmática. Madrid: Antropos.

(1993). Introducción a la pragmática. Barcelona: Ariel.

(1998).Cortesía y relevancia. In: La Pragmática lingüística del español: recientes desarrollos, Diálogos hispánicos, n 22, Ámsterdam, Rodopi. Disponível em: http://www.uned.es/dpto-leng-esp-y-linggral/escandell/public.htm\#ARTÍCULOS

(2004).Aportaciones de la pragmática. In: SANCHEZ LOBATO, J; SANTOS GARGALLO, I. Vademécum para la formación de profesores, Madrid, SGEL. pp. 179-198. Disponível em: <http:www.uned.es/dpto-lengesp-y-ling-gral/escandell/papers/AportPrag.PDF> . (2005). La comunicación. Madrid: Gredos.

FAIRCLOUGH, N. (2001). Discurso e mudança social. Brasília: Editora Universidade de Brasília.

FANT, L. M. (1989). Cultural mismatch in conversation:Sapnich and Scandinavian Communicative behavior in negotiation settings. Hermes: jornal of linguistics, pp. 247-265.

(2007a). La modalización del acierto formulativo en español.Revista internacional de lingüística iberoamericana, $\stackrel{n}{n}$. 9, pp. 39-58. Disponível em: $<$ http://docs.google.com/viewer?a=v\&q=cache:IJYUtcascm8J:www.ruc.dk/c uid/publikationer/publikationer/XVI-SRK-Pub/SPL/SPL08-

Fant/+lars+fant+marcadores+modalizaci\%C3\%B3n\&hl=ptBR\&gl=br\&pid=bl\&srcid=ADGEESixxpYUavERL8biv7SgA4NyWCYaY1SxC FaSJiehGpralrCetMqfd3yjFtogjRhHEV6t7WcOst_24hkeHIC8AsrjdTqKAhJPdra-sMk2OTLFoAnaVSNsL7yviFKqB6TG- 
7PsqFS\&sig=AHIEtbSnDydnNrao2_yok9Y3KueAHvx53A $\geq$. Acesso em: 19 ago. 2008.

(2007b).Rapport and identitiy management: a model and itsapplication to Spanish dialog. In: Placencia, M.E.; C. García-Fernández (Eds.). Research on Politeness in the Spanish-Speaking World, v.41. Nova lorque: Lawrence Erlbaum.

; GRANATO DE GRASSO, L. (2002): Cortesía y gestión interrelacional: hacia un nuevo marco conceptual.SIIS Working Papers IV: Departamento de Español, Portugués y Estudios Latinoamericanos, Universidad de Estocolmo, Estocolmo.

FRASER, B (1980). Conversational mitigation. Journal of Pragmatics,v.4, pp. 341350. 219-236.

(1990).Perspectives on Politeness.Journal of Pragmatics, v.14, pp.

FREYRE, G. (1933). Casa-grande \& Senzala.16.ed. Rio de Janeiro: José Olympio.

FUENTES RODRÍGUEZ, C. (1988). Vamos: un conector coloquial de gran complejidad. In: MARTíN ZORRAQUINO, M. A.; MONTOLÍO DURÁN, E. Los marcadores del discurso: teoría y análisis. Madri: Arco Libros, S.L.

GOFFMAN, E. (1961). Encounters: two studiesin the sociology of interaction.McGinnis (Ed.).Indiana University:Bobbs-Merrill Company, INC.

(1970). Ritual de la Interacción. Buenos Aires: Tiempo Contemporáneo. . (1979 [1971]). Relaciones en público. Madri: Alianza.

GRANATO, L.; HARVEY, A. (2005) "El cuestionamiento en la interacción verbal: un estudio de género." In: Pileux (ed.) Contextos del discurso. Valdivia: UACH/ Frasis, pp. 190-198.

GRICE, H. (1975). Logic and conversation. In: COLE, P.; MORGAN, J (Eds.).Syntax and semantics 3: speech acts, pp.41-58. Nova lorque: Academic Press.

GUERRERO, G. (1995). Neologísmo en el español actual. Madri: Arco/Libros.

GUMPERZ, J.J.; BENNET, A. (1981). Lenguaje y cultura.Barcelona: Anagrama. . (1982).Discourse Strategies. Cambridge: Cambridge UP.

GUTIÉRREZ, S. (1997). Principios de sintaxis funcional. Madri: Arco/Libros. 
HAVERKATE, H. (1994). La cortesía verbal. Madri: Gredos.

- (2004). El análisis de la cortesía comunicativa: categorización pragmalingüística de la cultura española.In: BRAVO, D; BRIZ, A.(Eds.).Pragmática Sociocultural: estudios sobre el discurso de cortesía en español. Barcelona: Ariel, pp. 55-66.

HARVEY, A. (2006). "Encuentros orales con fines de estudio: aproximaciones al tema", In: Falk, J.; Gille, J.; Wachtmeister, F (eds.) Discurso, interacción e identidad. Universidade de Estocolmo, pp. 137-162.

HERNÁNDEZ FLORES, N.(2002). La cortesía en la conversación española de familiares y amigos. La búsqueda del equilibrio entre la imagen del hablante y la imagen del destinatario. Tese de doutorado, Institut for Sprog og Internationale Kulturstudier, Aalborg Universitet, Aalborg, v. 37.

. (2003).Los tests de hábitos sociales y su uso en el estudio de la cortesía: una introducción. In: BRAVO, D. (Ed.).Actas del Primer Coloquio del Programa EDICE. La perspectiva no etnocentrista de la cortesía: identidad sociocultural de las comunidades hispanohablantes. Estocolmo: Programa EDICE, pp 186-197.

(2004). La cortesía como la búsqueda del equilibrio de la imagen social. In: BRAVO, D; BRIZ, A.(Eds.).Pragmática Sociocultural: estudios sobre el discurso de cortesía en español. Barcelona: Ariel, pp. 95-108.

HENRÍQUEZ SALIDO, M. C. (1995). Unidad y variedad del léxico español: para una caracterización general del habla de santiago de Chile. In:Congreso Internacional del Español de América, 4.,1992. El español de América: actas del IV Congreso Internacional de "El español de América".Santiago, Chile:Instituto de Letras, Pontificia Universidad Católica de Chile, v.2, pp. 961-977.

HYMES, D. (1972). "Models of the interaction of language and social life". In: J. Gumperz \& D. Hymes (Eds.), Directions in sociolinguistics: The ethnography of communication. Nova York: Holt, Rhinehart \& Winston, pp.35-71.

HOLANDA, S. B. de. (1936). Raízes do Brasil. 26.ed. São Paulo: Companhia da Letras.

IGLESIAS, S. (2001). Los estudios de la cortesía en el mundo hispánico. Estado de la cuestión. Oralia:Análisis del Discurso Oral, v.4, pp. 245-298.

JÖRGENSEN, A. M.; STENSTRÖM, A. B.; DANBOLT, E. M. D. Et. Al. Proyecto Cola. Corpus oral del lenguaje adolescente. Disponível em:<http://www.colam.tk/>.

KASPER, G. (1990). Linguistics politeness: current research issues. Journal of pragmatics,v.14, pp. 193-218. 
KERBRAT-ORECCHIONI, C. (1992). Les insteractions verbales. Paris: A. Colin.

. (2004). ¿Es universal la cortesía?.In: BRAVO, D.; BRIZ, A. (Eds.).

Pragmática sociocultural: estudios sobre el discurso de cortesía en español.

Barcelona: Ariel, pp. 39-54.

. (2005). Os atos de linguagem no discurso. Niterói: EDUFF.

.(2006).Análise da Conversação. Princípio e Métodos. São Paulo: Parábola.

KOCH, I. G. V. (2008). O texto e a construção dos sentidos. São Paulo: Contexto.

LAKOFF, R. (1973). The logic of politeness; or, minding your p's and q's. Papers from the regional meeting, Chicago linguistic Society. Chicago: Chicago linguistic Society, v.9, pp. 292-305.

LEECH, N. G. (1983). Principals of pragmatics. Londres: Longman.

LEVINSON, S. C. (2007). Pragmática. Tradução: Luis Carlos Borges e Aníbal Mari. São Paulo: Martins Fontes.

LIMA, F. B. de. (2012).Parecer bom x parecer justo: o pedido de desculpas na gestão da imagem nas interações midiáticas. Dissertação (Mestrado em Letras - Língua Espanhola e Literaturas Espanhola e Hispano-Americana), Faculdade de Filosofia, Letras e Ciências Humanas, Universidade de São Paulo, São Paulo.

LINELL, P. (1998). Aproaching dialogue. Amsterdam: John Benjamins.

LOPES, E. C. M. R. (2006) Breve estudio sobre las formas de atenuación en entrevistas semiformales de brasileños y chilenos. Monografia apresentada ao Programa de Doctorado en Filosofía y Letras, sección Filología Hispánica Universidad de Valladolid, Facultad de Letras, Pontificia Universidad Católica de Chile, Santiago.

.(2015) Análisis contrastivo de la atenuación en los grupos universitarios chilenos y brasileños: un estudio pragmalingüístico. Tese apresentada ao Programa de Doctorado en Filosofía y Letras, sección Filología Hispánica Universidad de Valladolid, Facultad de Letras, Pontificia Universidad Católica de Chile, Santiago.

LÓPEZ MORALES, H. (1994). Métodos de investigación lingüística. Salamanca: Ediciones Colegio de España.

MACEDO, A.T.; RONCARATI, C.; MOLLICA, M. C. (Orgs). (1996). Variação e discurso. Rio de Janeiro: Tempo Brasileiro. 
MALMBERG, B. (1966) La América hispanohablante. Unidad y diferenciación del castellano. Madri: Ediciones ISTMO.

MAO, L. (1994). Beyond politness teory: "Face" revisited and renewed. Journal of Pragmatics,v.21, pp. 451-486.

MARCUSCHI, L. A (2000). Análise da Conversação. 5ª ed. São Paulo: Ática.

. (2001).Da fala para a escrita: atividades de retextualização. 2. ed. São Paulo: Cortez.

. (2002).A repetição na língua falada de formulação textual. In KOCH, I.

G. V. (org.). Gramática do português falado. Vol. VI: Desenvolvimentos. 2.

Ed.Revista. Campinas: Unicamp.

MARTÍN ZORRAQUINO, M. A.; PORTOLÉS LÁZARO, J. (1999). Los marcadores del discurso. In: Bosque, Ignacio; Demonte, Violeta. Gramática descriptiva de la lengua española. Madri: Espasa Calpe / Real Academia Española, v.3, pp. 4051-4213.

MATSUMOTO, Y (1988). Reexamination of the university of face: Politeness phenomea in Japanese. Journal of Paragmatics, 12, pp. 403-426.

MENA, C. (2012). Ana María Stuven: Chile, el país de las mujeres solas. Paula, Santiago, Sociedad, Sociedad Chilena, 01 set. 2012. Disponível em:<http://www.paula.cl/entrevista/ana-maria-stuven-chile-el-pais-de-lasmujeres-solas/>. Acesso em: 11 jan. 2014.

MONTECINO SOTO, L. A. (2004).Estrategias de intensificación y de atenuación en la conversación coloquial de jóvenes chilenos. Onomázein,v.10, pp. 932.

(2005).Cortesía, ideología y representaciones discursivas en la en la gestión conversacional de jóvenes chilenos. Onomázein,v.12, pp. 9-22.

MORENO FERNÁNDEZ, F. (1998). Discurso y conversación. In: Principios de sociolingüística y sociología del lenguaje. Barcelona: Ariel, pp. 159-177.

OCHS, E. (1976).La universalidad de los postulados conversacionales. In: JULIO, M. T.; MUÑ̃Z, R. (Comps.).Textos clásicos de pragmática. Madri: Arco Libros, pp. 125-144, 1998.

PLACENCIA, M .E. (2001). Percepciones y manifiestaciones de la (des) cortesía: en la atención al público. El caso de una institución pública ecuatoriana.Oralia, v.4, pp. 177-212.

PRETI, D. (org.) (1993). Análise de textos orais. São Paulo: Humanitas.

. (1994).Sociolingüística. Os níveis de fala. São Paulo: Nacional. 
. (2005). Diálogos na fala e na escrita. São Paulo: Humanitas.

. (2006). Estudos de língua falada. 2.ed. São Paulo: Humanitas.

. (2008). Cortesia verbal. São Paulo: Humanitas.

PUGA LARRAín, J. (1997). La atenuación en el castellano de Chile. Universitat de València: Grupo de Estudios Iberoamericanos/ Tirant lo Blanch Libros.

. (2012). La observación participante en el estudio de la atenuación en el castellano de Chile. In:Escamilla Morales, J., y Henry Vega, G. (Eds.). Miradas multidisciplinares a los fenómenos de cortesía y descortesía en el mundo hispánico. Barranquilla: Universidad del Atlántico /Programa EDICE, pp. 413-450. Disponível em:<http://edice.org/>.

. (2013a). Cómo hablamos cuando hablamos: la atenuación en el castellano de Chile. Santiago de Chile: Ceibo Ediciones.

(2013b). Cómo hablamos cuando hablamos: setecientos tres ejemplos de atenuación en el castellano de Chile. Santiago de Chile: Ceibo Ediciones.

RAMIREZ GELBES, S. (2003). La partícula "eh" y la Teoría de la Relevancia: Un ejemplo de contenido procedimental. EstudiosFilológicos. [online],v.38, pp.157-

177. Disponível em:

$<$ http://www.scielo.cl/scielo.php?script=sci_arttext\&pid=S0071-

$17132003003800010 \&$ Ing=es\&nrm=iso $>$. Acesso em:15 abr. 2005

REYES, G. (1998) El abecé de la pragmática. Madri: Arco Libros.

(2002), Metapragmática: lenguaje sobre lenguaje, ficciones y figuras. Valladolid: Universidad de Valladolid / Secretariado de Publicaciones / Intercambio Editorial.

RODRÍGUEZ, M.A. (2000). El portugués y el español como lenguas extranjeras. ¿Fáciles y transparentes. Disponível em:

<http://www.centroalpha.com.ar/publications.htm>. Acesso em: 5 mai. 2007.

ROSA, M. (1992). Marcadores de atenuação. São Paulo: Contexto.

SACKS, H.; Schegloff, E. A.; Jefferson, G. (1974). A simplest systematics for the organization of turn-taking for conversation. Language, v.50, pp. 696735.

SCHEELE, J.E. (2010). Entre orden y caos: la formación de la cultura política chilena desde uma perspctiva histórica. Revista Pléyade, no. 5, 1ำ semestre de 2010, pp. 2-45. Disponível em: <www.caip.cl>.Acesso em: 11 de jan. 2014. 
SCOLLON, R.; SCOLLON, S. W. (1995).Intercultural Communication. A discourse approach. Oxford: Blackwell.

SEARLE, J. (1969).Speech Acts. Cambridge: Cambridge University Press.

SERRANI, S. (2001). Resonancias discursivas y cortesía en prácticas de lectoescritura. In: D.E.L.T.A.(Documentos de Estudos em Linguística Teórica e Aplicada), v.17, no.1. São Paulo: Educ, pp. 31-58.

(2005). Discurso e cultura na aula de lingua. Campinas: Pontes.

SILVA, L. A. (1998). Polidez na interação professor/aluno. In: Dino Preti. (Org.). Estudos de Língua Falada: Variações e Confrontos. São Paulo: Humanitas, v. 1 , pp.109-130.

SILVA, S. D. J.da. (2010) Análise e exploração de marcadores discursivos no ensino de português-língua estrangeira (PLE) no Brasil. Tese (Doutorado em Filologia e Língua Portuguesa) - Faculdade de Filosofia, Letras e Ciências Humanas, Universidade de São Paulo, São Paulo, 2010. Disponível em: <http://www.teses.usp.br/teses/disponiveis/8/8142/tde29112010-124503/>.

SINCLAIR, J.M; Coulthard, R.M. (1975) Towards an Analysis Of Discourse:The English used by teachers and pupils. Oxford: OUP.

SCOLLON, R.; SCOLLON, S. W. (1995). Intercultural Communication.Oxford: Blackwell.

SPENCER-OATEY, H. (2000) 'Rapport Management: A Framework for Analysis.' H. Spencer-Oatey (ed.), Culturally Speaking: Managing Rapport through Talk across Cultures. London/New York: Continuum, pp. 11-46.

SPERBER, D.; WILSON, D. (1986) Relevance: Communication and cognition. Blackwell: Oxford and Harvard UP/ Cambridge MA.

. (1994). La relevancia. Comunicación y procesos cognitivos. Madri: Visor.

(2001) Relevância: comunicação e cognição. Tradução: Helen Santos Alves; Revisão: Manuel Gomes da Torre.Lisboa: Fundação Calouste Gulbenkian.

STUVEN V. A. M. (2000). La seducción de un orden. Las elites y la construcción de Chile en las polémicas culturales y políticas del siglo XIX.Santiago: Ediciones de la Universidad Católica de Chile.

.(1997). Uma aproximación a la cultura política de la élite chilena: concepto y valoración del orden social (1830-1860), Estudios Públicos, v.66, otoño, pp. 250-311. Disponível em: 
<http://www.cepchile.cl/1_1159/doc/una_aproximacion_a_la_cultura_politic a_de_la_elite_chilena_concepto_y_valoraci.html\#.UvmqfmJdVck>.Acesso em: 11 jan. 2014.

TAGLE DOMINGUEZ, M.;STUVEN V, A. M. (2014).La seducción de un orden. Las elites y la construcción de Chile en las polémicas culturales y políticas del siglo XIX. Historia (Santiago), vol.34, Santiago, 2001. Disponível em: $<$ http://www.scielo.cl/scielo.php?script=sci_arttext\&pid=S071771942001003400015\&lng=es\&nrm=iso >. Acesso em: 10 jan. 2014. <http://dx.doi.org/10.4067/S0717-71942001003400015>.

VERSCHUEREN, J. (1999), Understanding Pragmatics. London: Edward Arnold. Versão espanhola: Elisa e Marta Lacorte. (2002).Para entender la pragmática. Madri: Gredos.

VILLAÇA, I. G.; BENTES, A. C. (2008). Aspectos da cortesia na interação face a face. In: PRETI, D. (Org.). Cortesia verbal. São Paulo: Humanitas

WASSERMAN, F. "Las prendas jeniales de nuestra sociedad": representaciones del pasado e identidad nacional en el discurso de las élites político-letradas chilenas (1840-1860). Iberoamericana. América Latina - España - Portugal, Nueva Época, año III, ํo.9, Instituto Iberoamericano, Berlín, março de 2003, pp. 7-26.

WILSON, D.; SPERBER, D. (1993).Linguistic form and relevance. Lingua 90, 1/2, v. 2: 1-25. Special Issue on Relevance Theory. Versão recente:Working Papers in Linguistics 2: 95-112 (1990). 


\section{ANEXO}

\section{Exemplos do corpus oral (filmagens)}

\section{Transcrição 2o Grupo - Brasileiros}

G: então esse probleminha ((aqui tá)) entende que precisa de consolo/ que alguém precisa de um consolo/mas§

C: $\quad$ Sé mas é porque é uma expressão tipicamente francesa a gente só vai poder usar ((elle bien besoin)) num sei que lá ah ela bem que precisa disso mas é que em português a gente não fala tanto $\uparrow$ isso existe mas a gente não fala tanto que nem em francês/ em francês é bem mais recorrente que no [português]

G:

mesmo, ¿né?, isso aqui?

[uhn//uhn] ${ }^{62}$ se todas/// ¿é cê

C: é/ exatamente

G: se todas essas desculpas/// não foi suficiente $\uparrow$

C:é/não// é/ não foi suficiente/ [não existe verbo]

G:

[verbo]/ suficientar/ não

(RISOS)

C: (( ))suficientar

G: não foi suficiente// péra aí/// ((je veux)) eu quero

C: exatamente ((rah! / pondo em prática))

G: (RISA)/// eu quero bem (( )) §

C:

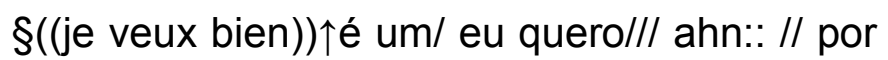
exemplo// é que no português isso não aparece $\downarrow$ mas por exemplo// quando você fala/ ahn::/ ((je veux bien prendre un glacê))

G: ((isso na gravação vai ficar engraçado) $)^{63}$

C: ((je veux bien prendre un glacê)) ah::/ eu quero tomar um sorvete/ só que tá vendo que esse ((bien)) some em português/ significa que você quer/ é uma expressão/ é uma expressão/ eu não consigo chegar na tradução exata dela

G: tudo bem/ deu pra:/ $\S$

C: $\quad$ \$deu pra entender o espírito, ¿né??

G: deu/// ${ }^{64}$ se todas as desculpas não// forem o suficiente// eu quero dedicar este livro/ à criança// que:/ foi / outra//vez§

C:

§é $\downarrow$ eu acho que na tradução isso sumiria/ ¿né?/ que foi/ a criança foi (( )) pessoas grandes

G: todas as pessoas grandes// $i(($ conquistam $))$ ?

C: ahn:/ isso é do:: ((avoir))/aqui você tem uma forma composta com// ((etê))/ é porque esse aqui ele é o:.:: / eu esqueci o nome/ mas ((você tem que)) coloca ele no meio

\footnotetext{
62 Se reinicia la lectura.

${ }^{63}$ El chico toma agua y se averguenza porque la derrama. Entre risas, retoman el estudio.

${ }^{64}$ Se reinicia la lectura.
} 


\section{Transcrição 7ำ Grupo - Chilenos}

$((\ldots))$

A: yo creo que primero deberíamos ver la cuestión de loo / de loh tiempoh / porque estamoh súper ajustadoh $\uparrow$ / ( (pa que noh empecemoh)) a dividir tareeas $\uparrow$ / porque de aquí a hacerlo en conjuunto $\uparrow$ B: es que / yo creo / (()) tenemos que traer ((la)) problemática $\uparrow$ / y que tan acotadoo seea $\uparrow$ lo damos C: $\quad$ [ ( ( )) ]

según $\quad($ los $\quad$ grupos $)) \downarrow$ C: claro pô / que yo le de- yo creo que deberíamos dejar como las temáticas ahora $\uparrow / /$ y empezar altiro a alinear cuestiones pa que'l próximo lunes tengamos como el / el proyecto ma- medianamente armaô / ((lo que pretendemos))

D: si pô / sabî / pa que noh diga si en verdá' está bien po

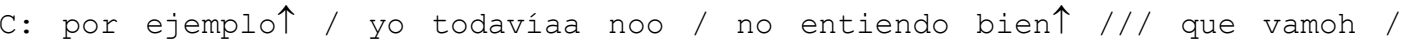
supuestamente en la temáticaaa ee / ((de loh díaah)) / en que soon = $\$$ ?: $\$$ [ $\$(())]$ $\mathrm{E}: \quad$ S $\quad[(())]$ C: pero cuál es la programática de eso? E: lo- lo que vimos la semana pasá po / de como como cambian los sostenedores en el tiempô / de quee / cual eh- cual es el cambio que se genera / de que hayann en principio hayann / sostenedores de una tendencia más bien liberal cachai个 // y como en la actualidaad son / son ee / sostenedoreeh que- bueno económicamente liberales pero son / conservadores $\downarrow$

$\mathrm{C}:$

B:

[conservadores]

[conservadores] $\downarrow$ $\$$

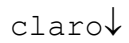

F: entoncees / no serviría tantoo aa ((los profes)) como empleadores $\uparrow$ A: lo que pasa es queeE: $\quad[(())]$

?: [no sirvee] / porque ahii en B: el profe nos dijo que tenía que ser / CUANTITATIVo $\uparrow$ / y CUALITATIVo $\uparrow=$ ?: $\quad[y \quad$ cualitativo $\downarrow]$ $\mathrm{B}:=$ entonces // claramente ((el Marco te va a preguntar)) / va a preguntar más lo CUALITATIVo $\downarrow$ / pero eso no significa quee / por ejemplo si vamoh a hacer como algo histórico $\uparrow$ / igual tenemos que ver como see=

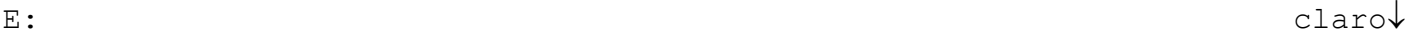
B: por ejemplo / CUÁNTOS COLEGIOOH / tiene $\uparrow$ / o que QUE lugar tienen colegioh $\uparrow$

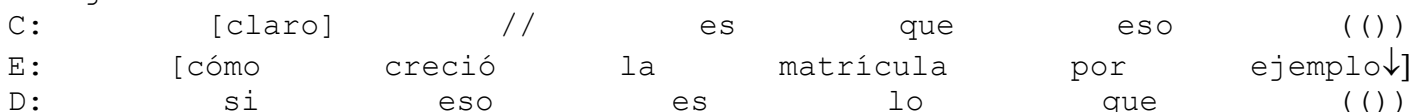
C: lo que pasa es que / el profe ((dijo)) hacer algo $\rightarrow$ / cualitativo

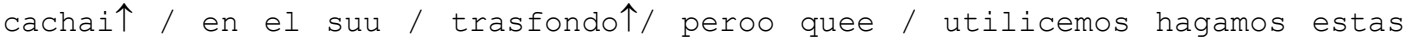

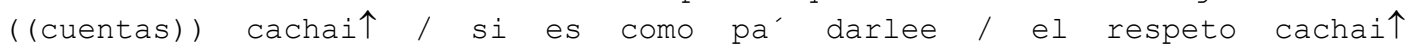
?:

$\mathrm{D}:$

el

eteerno

$[(())]$

B: (() ) / quienes son los sostenedores ahora $\uparrow /$ osea quienes B: (() / quienes son los sostenedores ahora / osea quienes conforman la sociedad de ((instrucción))(()) $\uparrow$ $\mathrm{E}:$ [claro]

si cual eh- cuál es la lógica que se mueve detrás de la sociedad de instrucción primaria porque // ee/ en principio no- no funcionaba bajo la lógica empresarial个 / y ahora claramente eh una empresa / asii 


\section{Signos del sistema de transcripción Val.Es.Co. (2002)}

: Cambio de voz.

A: Intervención de un interlocutor identificado como A.

?: Interlocutor no reconocido.

$\S$ Sucesión inmediata, sin pausa apreciable, entre dos emisiones de distintos interlocutores.

= Mantenimiento del turno de un participante en un solapamiento.

[ Lugar donde se inicia un solapamiento o superposición.

] Final del habla simultánea.

- Reinicios y autointerrupciones sin pausa.

/ Pausa corta, inferior al medio segundo.

// Pausa entre medio segundo y un segundo.

/// Pausa de un segundo o más.

(5") Silencio (lapso o intervalo) de 5 segundos; se indica el $n^{\circ}$ de segundos en las pausas de más de un segundo, cuando sea especialmente significativo.

$\uparrow$ Entonación ascendente.

$\downarrow$ Entonación descendente.

$\rightarrow$ Entonación mantenida o suspendida.

Con nombres propios, apodos, siglas y marcas, excepto las convertidas en "palabrasmarca" de uso general, aparecen con la letra inicial en mayúscula.

PESADO Pronunciación marcada o enfática (dos o más letras mayúsculas).

pe sa do Pronunciación silabeada.

(( )) Fragmento indescifrable.

((siempre)) Transcripción dudosa.

$((\ldots))$ Interrupciones de la grabación o de la transcripción.

(en)tonces Reconstrucción de una unidad léxica que se ha pronunciado incompleta, cuando pueda perturbar la comprensión.

pa'l Fenómenos de fonética sintáctica entre palabras, especialmente marcados.

${ }^{\circ}()^{\circ}$ Fragmento pronunciado con una intensidad baja o próxima al susurro.

h Aspiración de "s" implosiva.

(RISAS, TOSES

GRITOS...) Aparecen al margen de los enunciados. En el caso de las risas, si son simultáneas a lo dicho, se transcribe el enunciado y en nota al pie se indica "entre risas".

aa Alargamientos vocálicos.

nn Alargamientos consonánticos.

¿i !? Interrogaciones exclamativas.

¿ ? Interrogaciones. También para los apéndices del tipo "¿no?, ¿eh?, ¿sabes?"

i! Exclamaciones.

és que se pareix a mosatros: Fragmento de conversación en valenciano. Se acompaña de una nota donde se traduce su contenido al castellano.

Letra cursiva: Reproducción e imitación de emisiones. Estilo directo, característico de los denominados relatos conversacionales.

Notas a pie de página: Anotaciones pragmáticas que ofrecen información sobre las circunstancias de la enunciación. Rasgos complementarios del canal verbal.

* Las incorrecciones gramaticales (fónicas, morfosintácticas y léxicas) no aparecen marcadas por lo general. Así pues, según el usuario del corpus (especialmente si se utiliza por un estudiante de español como segunda lengua), puede ser recomendable el soporte explicativo del profesor.

* Los antropónimos y topónimos no se corresponden por lo general con los reales.

El primer ejemplo constituye un extracto del corpus de entrevistas del español hablado 